\title{
HYDROLOGY AND WATER QUALITY OF DELAVAN LAKE IN SOUTHEASTERN WISCONSIN
}

By

Stephen J. Field and Marvin D. Duerk

Water-Resources Investigations Report 87-4168

Prepared by

United States Department of the Interior

Geological Survey

In cooperation with the

Delavan Lake Sanitary District 


\section{DEPARTMENT OF THE INTERIOR}

DONALD PAUL HODEL, SECRETARY

\section{U.S. GEOLOGICAL SURVEY}

Dallas. L. Peck, Director

For additional information write to:

\section{District Chief}

U.S. Geological Survey, WRD

6417 Normandy Lane

Madison, Wisconsin 53719
Copies of this report can be purchased from:

U.S. Geological Survey

Books and Open-File Reports Section

Federal Center, Box 25425

Building 810

Denver, Colorado 80225 


\section{CONTENTS}

Abstract

Introduction 1

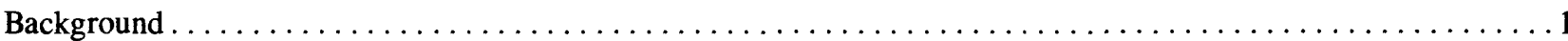

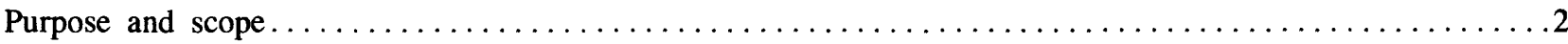

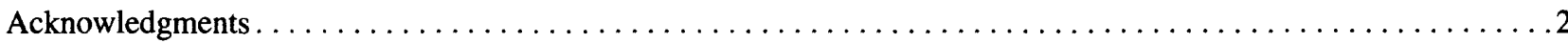

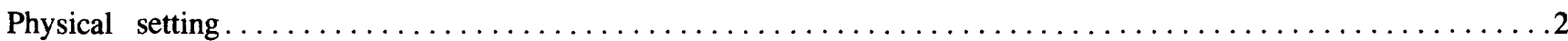

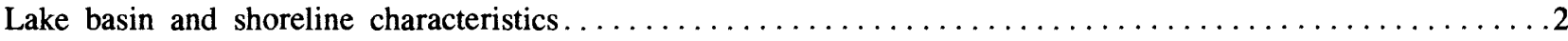

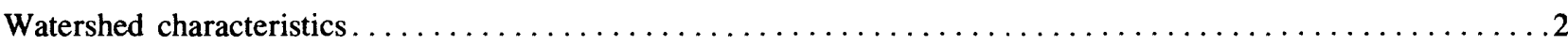

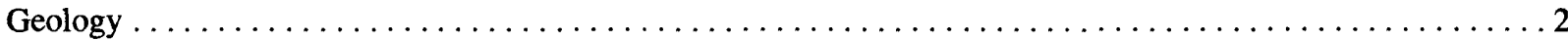

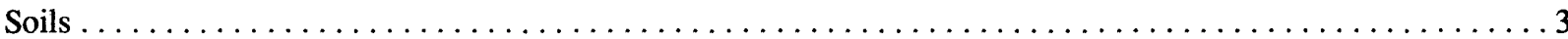

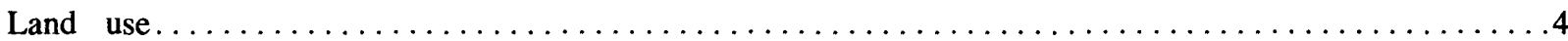

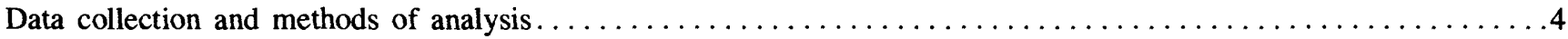

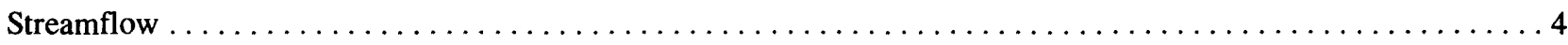

Ground $w^{2}$

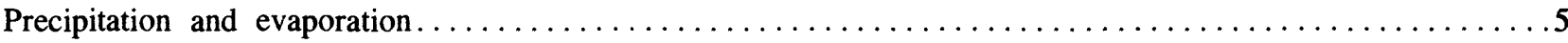

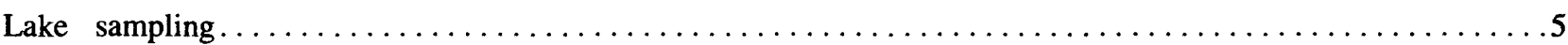

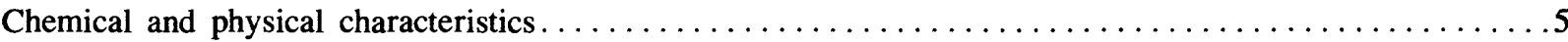

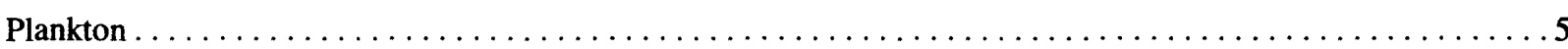

Benthic invertebrates. . . . . . . .

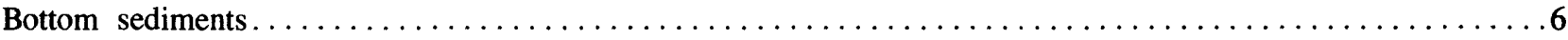

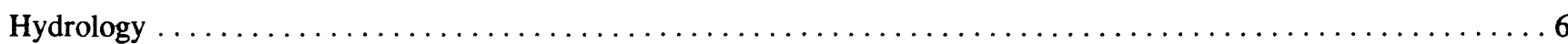

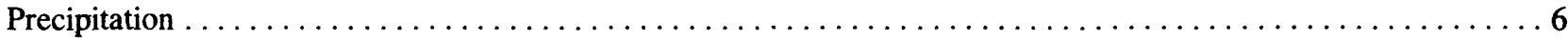

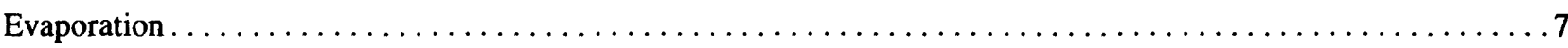

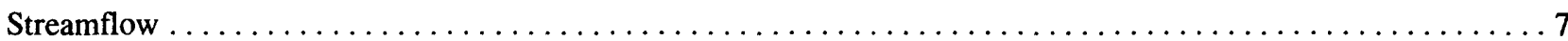

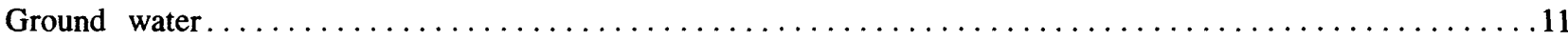

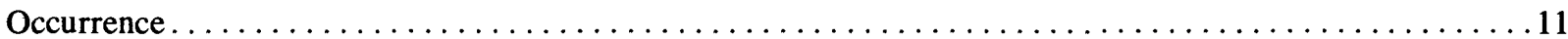

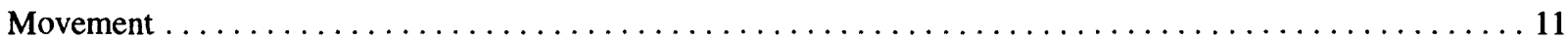

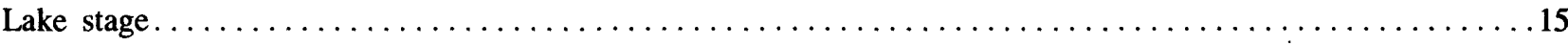

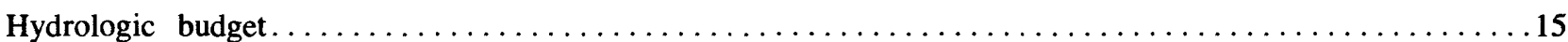

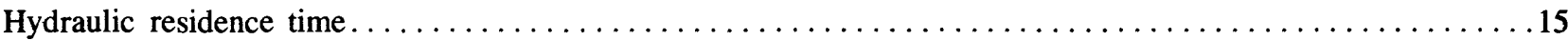

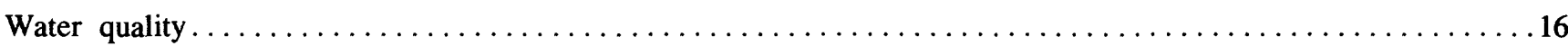

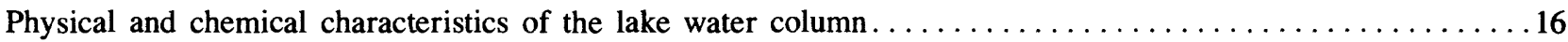

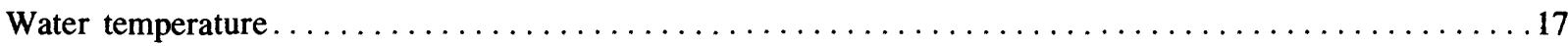

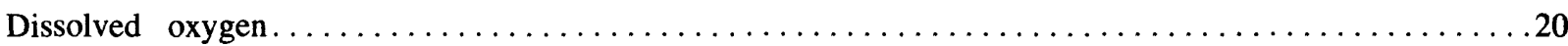

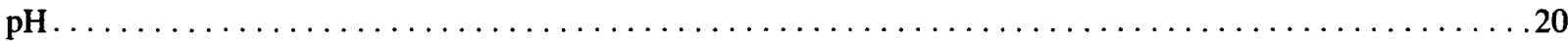

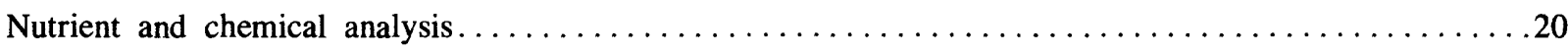

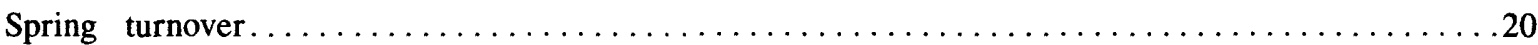

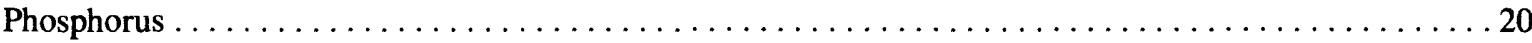

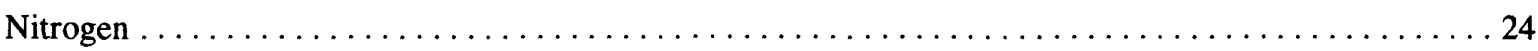

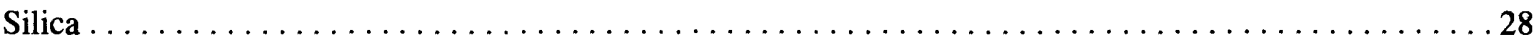




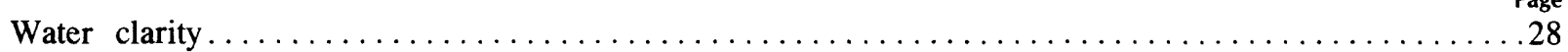

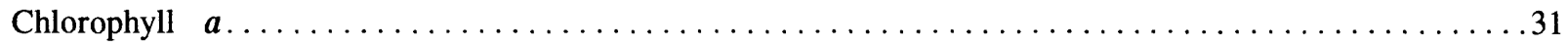

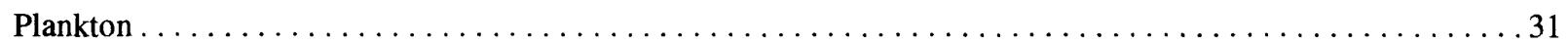

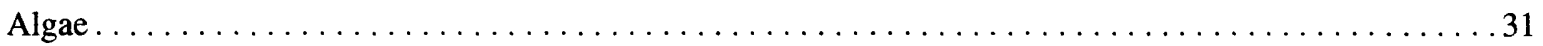

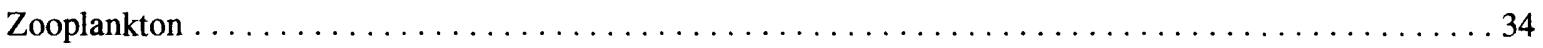

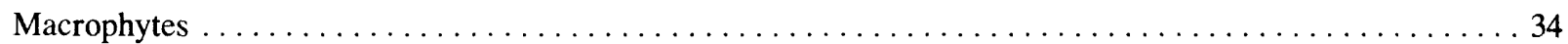

by Robert Wakeman

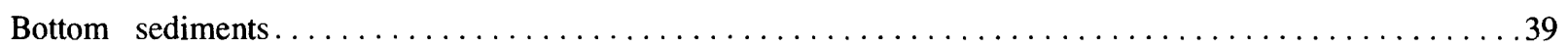

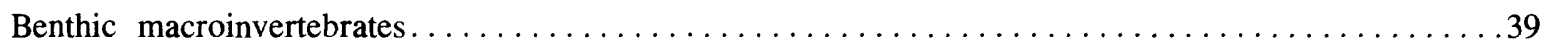

Sediments at Delavan Lake inlet..................................40

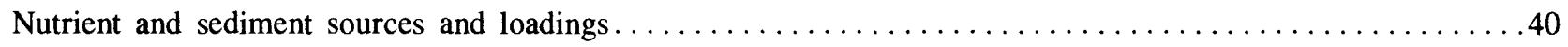

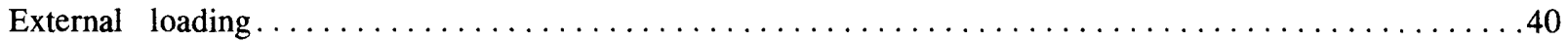

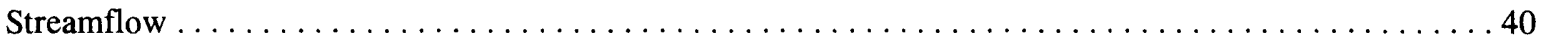

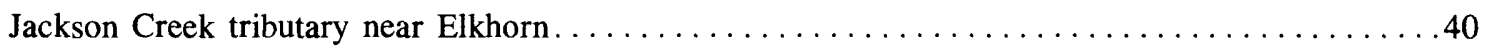

Jackson Creek at Petrie Road near Elkhorn............................. 42

Delavan Lake inlet.......................................... 42

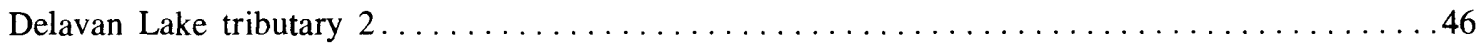

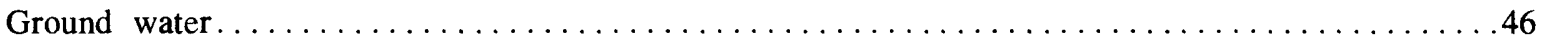

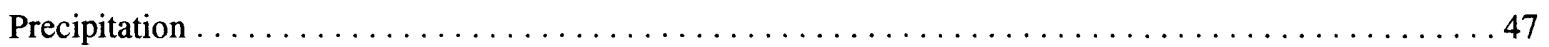

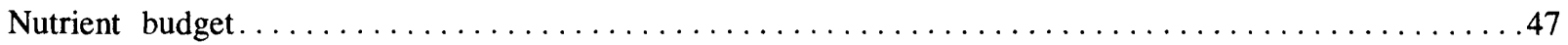

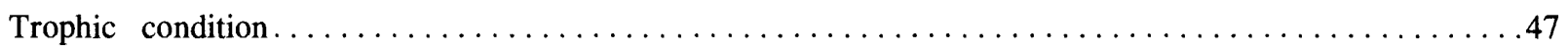

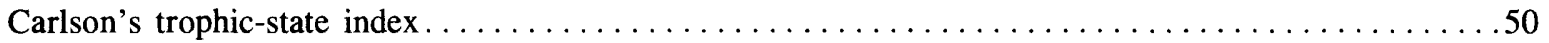

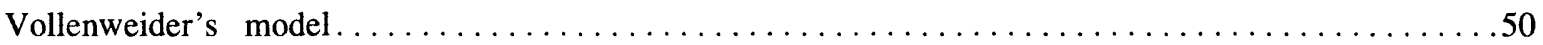

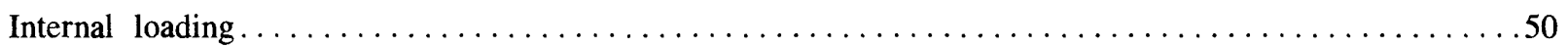

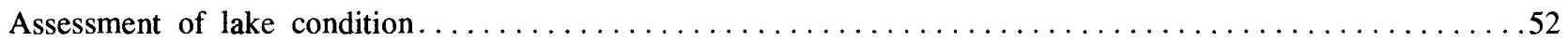

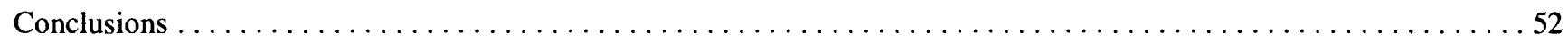

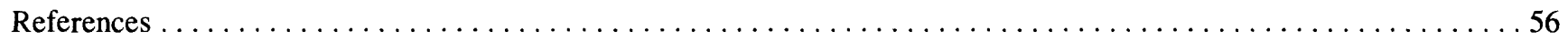

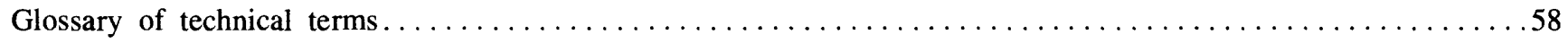

\section{ILLUSTRATIONS}

Figure 1. Map showing Delavan Lake drainage basin and monitoring sites...................... Page

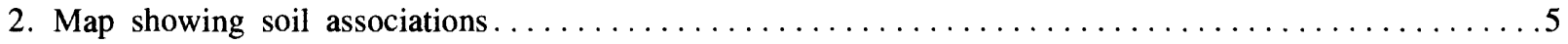

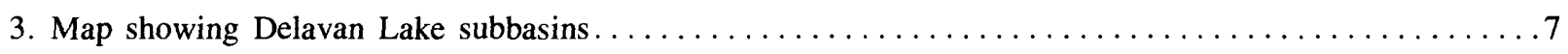

4. Bathymetric map of Delavan Lake showing benthic-macroinvertebrate sampling sites . . . . . . . .9

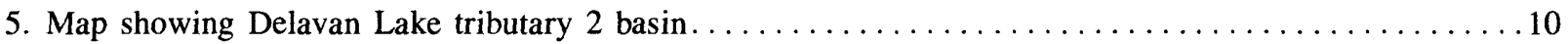

6. Graph showing discharge of Delavan Lake tributary 2 and Jackson Creek, 1985 water year.........11

7. Map showing generalized regional water-table configuration and ground-water movement $\ldots \ldots \ldots \ldots 12$

8. Graphs showing relation between water level in wells within 10 feet of Delavan Lake's

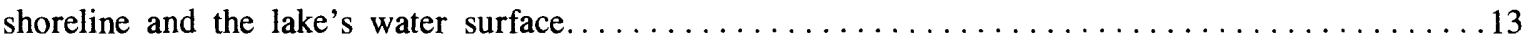

9. Graphs showing water-level fluctuations in ground-water wells in and near Delavan Lake basin. . . . . 14

10. Graph showing depth profiles of water temperature and dissolved oxygen in Delavan Lake, 1984 and 1985 water years. 
11. Graphs showing depth profiles of $\mathrm{pH}$ in Delavan Lake, 1984 and 1985 water years. . . . . . . ...21

12. Graph showing trends in total phosphorus concentration in Delavan Lake, 12-month,

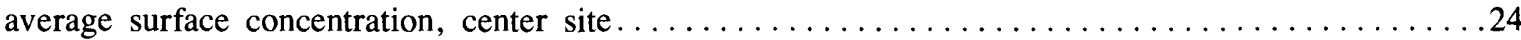

13. Graphs showing phosphorus and algal concentrations in Delavan Lake, in the bottom

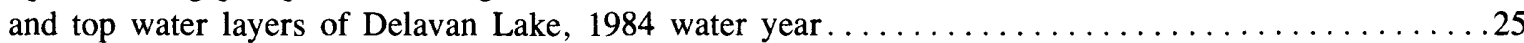

14. Graphs showing phosphorus and algal concentrations in the bottom and top water layers

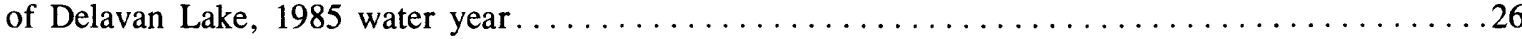

15. Graphs showing total phosphorus mass balance for Delavan Lake, 1984 and 1985 water years......27

16. Graphs showing nitrogen concentrations in the bottom and top water layers of Delavan Lake,

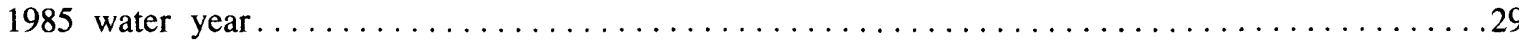

17. Graphs showing dissolved silica concentrations, top and bottom water layers of Delavan Lake, 1984 and 1985 water years.

18. Graphs showing Secchi disc transparencies, chlorophyll $a$ concentrations, and chelated

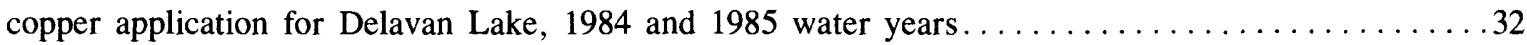

19. Graphs showing types of algae in Delavan Lake, 1984 and 1985 water years .................33

20. Graphs showing zooplankton species, southwestern end of Delavan Lake, 1984 and

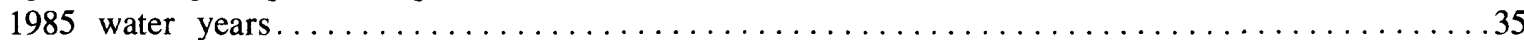

21. Graphs showing zooplankton species, northeastern end of Delavan Lake 1984 and

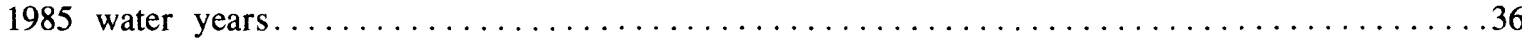

22. Graphs showing total population of phytoplankton and zooplankton, Delavan Lake,

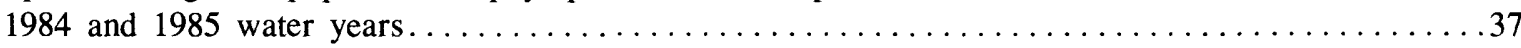

23. Map showing distribution of macrophytes, June 12 and July 10, 1984, and $1985 \ldots \ldots \ldots \ldots \ldots . \ldots 38$

24. Graphs showing suspended sediment-total phosphorus relations at nonpoint-source-pollution

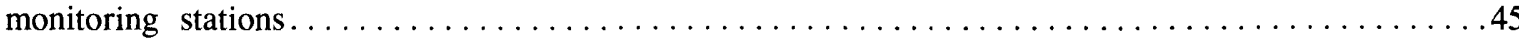

25. Graphs showing total phosphorus concentrations at Delavan Lake inlet and outlet............48

26. Graphs showing trophic-state indices, 1984 and 1985 water years....................... 48

27. Graphs showing nitrogen- and phosphorus-loading classifications for Delavan Lake

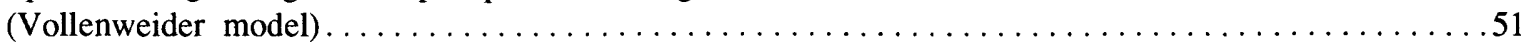

28. Graphs showing Delavan Lake in-lake phosphorus mass, 1972 and $1983-86 \ldots \ldots \ldots \ldots \ldots \ldots . \ldots 5$

\section{TABLES}

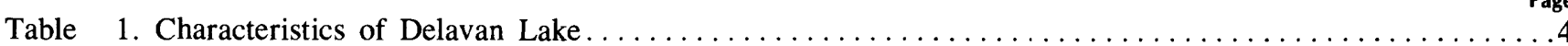

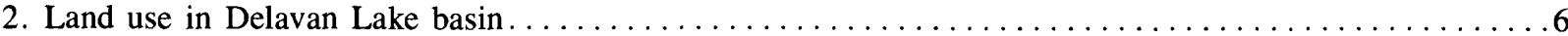

3. Precipitation at Delavan Lake and Lake Geneva, 1984 and 1985 water years. . . . . . . . . . . . . . . . . .8

4. Evaporation data for Delavan Lake, 1984 and 1985 water years . . . . . . . . . . . . . . . . . . 8

5. Summary of streamflow characteristics for Delavan Lake basin and Turtle Creek at

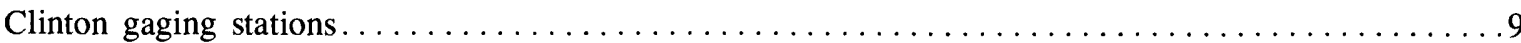

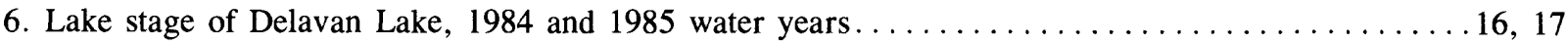

7. Hydrologic budget for Delavan Lake, 1984 and 1985 water years......................... 18

8. Spring water chemistry, April 17, 1984, and April 3, 1985, Delavan Lake................22, 23

9. Phosphorus, iron, manganese, arsenic, and moisture content of bed material at maximum

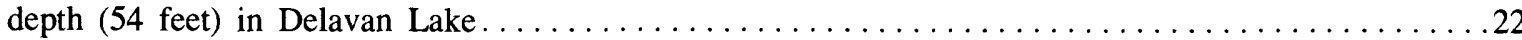

10. Benthic macroinvertebrate count, Delavan Lake, 1984 and 1985 water years..................... 39

11. Results and sites of sediment survey of Delavan Lake inlet $\ldots \ldots \ldots \ldots \ldots \ldots \ldots \ldots \ldots \ldots \ldots \ldots$

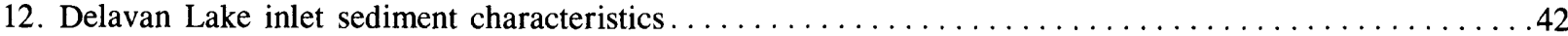


13. Nutrient and suspended-sediment loads and yields in the Delavan Lake drainage basin,

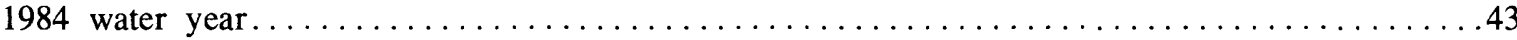

14. Nutrient and suspended-sediment loads and yields in the Delavan Lake drainage basin, 1985 water year $\ldots \ldots \ldots \ldots \ldots \ldots \ldots \ldots \ldots \ldots \ldots \ldots \ldots \ldots \ldots \ldots \ldots \ldots$

15. Statistical summaries of nutrient and suspended-sediment concentrations in runoff at the four Delavan Lake inflow gaging stations $\ldots \ldots \ldots \ldots \ldots \ldots \ldots \ldots \ldots \ldots \ldots \ldots \ldots \ldots$

16. Annual phosphorus and nitrogen budget for Delavan Lake, 1984 and 1985 water years . . . . . . . .49

17. Summary of total phosphorus (TP) input, output, and changes in the water column,

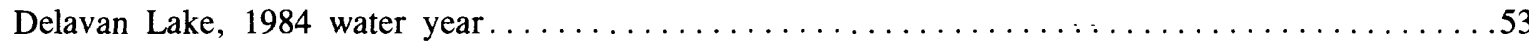

18. Summary of total phosphorus (TP) input, output, and changes in the water column,

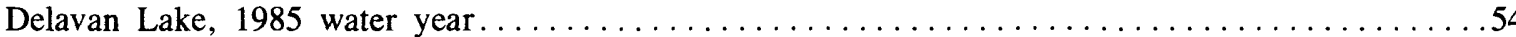

Appendices are available at the U.S. Geological Survey, WRD, Wisconsin District office on request.

Appendix 1 (a-d)-Phytoplankton populations of Delavan Lake, 1984 and 1985 water years.

Appendix 2 (a-d)-Zooplankton populations of Delavan Lake, 1984 and 1985 water years.

Appendix 3 (a-d)-Benthic macroinvertebrates of Delavan Lake, 1984 and 1985 water years.

Appendix 4 (a-h)-Water-quality loads at Jackson Creek, 1984 and 1985 water years.

Appendix 5 (a-h)-Water-quality loads at Jackson Creek tributary, 1984 and 1985 water years.

Appendix 6 (a-h)-Water-quality loads at Delavan Lake tributary 2, 1984 and 1985 water years.

Appendix 7 (a-h)-Water-quality loads at Delavan Lake outlet, 1984 and 1985 water years.

\section{CONVERSION TABLE AND ABBREVIATIONS}

For the use of readers who prefer the metric (International System) units, the conversion factors for the inch-pound terms used in this report are listed below.

Multiply inch-pound unit

inch (in.)

inch (in.)

mile (mi)

pound (lb)

acre

gallon (gal)

foot (ft)

yard $(\mathrm{yd})$

acre-foot (acre-ft)

cubic foot $\left(\mathrm{ft}^{3}\right)$

micrograms per liter $(\mu \mathrm{g} / \mathrm{L})$

$\frac{\text { By }}{25.4}$
$25.4 \times 10^{-3}$
1.609
453.6
, 047

$3.785 \times 10^{-3}$

0.3048

0.9144

$1.233 \times 10^{3}$

$2.832 \times 10^{-2}$

Other Conversions

$1 \times 10^{-3}$
To obtain metric unit

millimeter (mm) micrometers $(\mu \mathrm{m})$

kilometer $(\mathrm{km})$ gram (g) square meter $\left(\mathrm{m}^{2}\right)$ cubic meter $\left(\mathrm{m}^{3}\right)$ meter (m) meter (m) cubic meter $\left(\mathrm{m}^{3}\right)$ cubic meter $\left(\mathrm{m}^{3}\right)$

milligrams per liter (mg/L)

Temperature, in degrees Fahrenheit $\left({ }^{\circ} \mathrm{F}\right)$ can be converted to degrees Celsius $\left({ }^{\circ} \mathrm{C}\right)$ by use of the following equation: ${ }^{\circ} \mathrm{C}=5 / 9\left({ }^{\circ} \mathrm{F}-32\right)$.

Sea level: In this report "sea level" refers to the National Geodetic Vertical Datum of 1929 (NGVD of 1929)-a geodetic datum derived from a general adjustment of the first-order level nets of both the United States and Canada, formerly called "Mean Sea Level of 1929." 


\title{
HYDROLOGY AND WATER QUALITY OF DELAVAN LAKE IN SOUTHEASTERN WISCONSIN
}

\author{
By \\ Stephen J. Field and Marvin D. Duerk
}

\begin{abstract}
Delavan Lake is a eutrophic, recreational lake in a densely populated area of southeastern Wisconsin. Sewage effluent and septic tank drainage were diverted out of the drainage basin of the lake to improve its water quality in 1981. The worst known blue-green algal bloom occurred in the lake in the summer of 1983. A comprehensive hydrologic and water-quality investigation was started in October 1983 to determine why the water quality in the lake apparently had not improved after cessation of influxes of waste waters. This report describes the hydrology and water quality of Delavan Lake and its drainage basin during the 1984 and 1985 water years.
\end{abstract}

All major external inputs and outputs of phosphorus and nitrogen to the lake were measured to assess the importance of each source. Internal loading of phosphorus was calculated as a residual of a mass-balance budget. The in-lake phosphorus mass during the 2-year study shows a gradual declining trend that suggests an improving lake condition but also could be due to a random phosphorus decline. Future monitoring will be needed to determine whether the decline in phosphorus has indeed occurred as a result of waste-water diversion.

Continuous streamflow and water-quality monitoring in the subbasins of the Delavan Lake watershed showed a wide range of annual phosphorus and nitrogen yields during the study. Jackson Creek tributary, which predominantly drains the city of Elkhorn, had the highest average yields of phosphorus ( 838 pounds per square mile) and Kjeldahl nitrogen ( 3,600 pounds per square mile). These yields were almost three times those found in the Jackson Creek basin, which has the largest livestock population. The other major tributary, Delavan Lake tributary 2, had much lower average annual yields of phosphorus (53.1 pounds per square mile) and Kjeldahl nitrogen (550 pounds per square mile). The lower yields in this tributary result from significantly reduced runoff caused by storage and evapotranspiration in a large pond that is surrounded by a wetland in the stream's basin.

External loading of phosphorus and nitrogen were sufficient to cause eutrophic conditions. Internal loading of phosphorus was more than two times the external phosphorus supply. Most of the internal loading occurred when the hypolimnion was anoxic during summer. Internal loading of phosphorus during the 1985 water year was significantly reduced from that of 1984 because of a shorter anoxic period.

\section{INTRODUCTION}

\section{BACKGROUND}

Delavan Lake is a eutrophic, dimictic lake located in Walworth County in southeastern Wisconsin. Much of the lake's eutrophication can be attributed to the input of phosphorus by sewage effluent in the past. The Environmental Protection Agency (EPA) found during a 1972 survey that about three-quarters of the annual external phosphorus input came from three sewage-treatment plants (Environmental Protection Agency, National Eutrophication Survey, 1974). The city of Elkhorn contributed the largest amount (75 percent) of the sewage-treatment plant effluent.

A sewage diversion was begun in April 1979 to reduce phosphorus and nitrogen input. By October 1981, at an expense of 42 million dollars, all sewage-treatment plant effluent from the basin was diverted and all homes and businesses within $0.3 \mathrm{mi}$ (mile) of the lakeshore were sewered. These effluents and domestic wastes are pumped out of the basin for treatment. 
A severe blue-green algal bloom in the lake during the summer of 1983 caused complaints from the residents and businesses located around the lake. In October 1983 the U.S. Geological Survey, in cooperation with the Delavan Lake Sanitary District (DLSD) and the Wisconsin Department of Natural Resources (DNR), began a 2-year water-quality and hydrologic investigation to describe water-quality conditions in Delavan Lake and its drainage basin and probable causes of continuing algal problems.

Significant changes in the Delavan Lake ecosystem have occurred during the past 50 years. Rooted aquatic vegetation was treated heavily with arsenic in the 1930's and lakeshore property owners initiated copper sulfate applications in 1939 (Schumacher and Burns, 1978). A decline of rooted aquatic vegetation occurred from 1950 to 1958 and it changed the base of primary productivity from a combination of rooted aquatics and algal production to a system solely of algal production. Large algal blooms, composed generally of Microcystis sp. began to appear consistently in about 1955 . Bigmouth buffalo, Ictiobus cyprinellus, were able to outcompete carp, Cyprinus carpio, for the planktivorous food base and gain predominance in the system (Schumacher and Burns, 1978).

\section{PURPOSE AND SCOPE}

The purpose of the study was to provide information on the hydrology and water quality of Delavan Lake and its drainage basin for use by local and State agencies in developing lake- and land-management alternatives for improving the water quality of Delavan Lake.

The primary objectives of this study were to determine the nutrient loads into the lake from surface water, ground water, and precipitation. The in-lake objectives are as follows: (1) to determine nutrient loads from internal recycling; (2) to determine the chemical characteristics of the water and bottom sediments of the lake and other physical characteristics, and to determine the chemical characteristics and volume of the soft sediments in Delavan Lake Inlet; (3) to identify the phytoplankton, zooplankton, benthic invertebrates, and rooted aquatic macrophytes present; and (4) to determine the nutrient discharges from the lake from surface and ground water.

This report summarizes the results of the intensive monitoring program from October 1983 through September 1985, and provides an evaluation and interpretation of the data. Streamflow and water-quality monitoring of Delavan Lake and its basin were continued in the 1986 water year, at a much reduced schedule from that described in this report. Appendices of phytoplankton and zooplankton populations and benthic macroinvertebrates; daily water-quality loads at Jackson Creek, Jackson Creek tributary, Delavan Lake tributary 2, and Delavan Lake outlet are available at the Wisconsin District office upon request.

\section{ACKNOWLEDGMENTS}

We would like to give special recognition to Marvin D. Duerk, who died on December 20, 1987. Marv provided valuable assistance in collection of and analysis of the data for this study. His efforts in assuring that data were collected during a variety of adverse conditions were an important part in establishing the excellent data base for this study. His contributions to water-resources studies in Wisconsin will be sorely missed in the future.

We would like to thank personnel from the Delavan Lake Sanitary District, especially Barry Kjelland, who assisted with most of the data collection; Neal O'Reilly, Wisconsin Department of Natural Resources, who assisted in the design of the monitoring program; Robert A. Lidwin, U.S. Geological Survey, who identified the benthic invertebrates; and Robert Wakeman, Wisconsin Department of Natural Resources, who identified macrophytes and wrote the part of this report about them.

\section{PHYSICAL SETTING}

\section{LAKE BASIN AND SHORELINE CHARACTERISTICS}

Delavan Lake was formed during the late Wisconsin glaciation, which ended 10,000 years ago. The basin has moderate relief with gently undulating plains. The lake's drainage basin is part of the Turtle Creek system. Major surface-water inflow to the lake is from Jackson Creek, through Delavan Lake inlet, at the northeastern end of the lake (fig. 1). The second largest inflow to the lake is from an unnamed tributary at the southwestern end of the lake. The immediate drainage area surrounding the lake is occupied mostly by 2,200 homes and businesses.

Delavan Lake inlet (fig. 1) upstream of State Highway 50 is extremely shallow [less than $3 \mathrm{ft}$ (feet) deep], $0.2 \mathrm{mi}$ wide, and $1.8 \mathrm{mi}$ long. Many carp and bigmouth buffalo search for food in this area and also use it during spawning. The outlet of the lake is at the northwestern end, $2 \mathrm{mi}$ from the inlet.

A dam at the outlet was constructed in the mid 1930's (K. L. MacKinnon, DLSD, written commun., 1985), to deepen the lake about $8 \mathrm{ft}$. The practice of dropping lake levels $0.75 \mathrm{ft}$ about the first of October to prevent ice damage to shoreline structures and raising water levels to pre-October levels in April to May has been followed for many years. Lake levels are controlled by the town of Delavan. Basic hydrographic and morphometric data of Delavan Lake are presented in table 1 .

\section{WATERSHED CHARACTERISTICS}

\section{Geology}

Delavan Lake was formed by the Delavan Lobe of the Lake Michigan glacier during Wisconsin Glaciation. The drainage basin contains glacial deposits of unconsolidated material of Quaternary age (Borman, 1976) that range from $150 \mathrm{ft}$ in thickness in the northeastern part of the basin to $450 \mathrm{ft}$ thick in the southeastern part. These sediments are end and ground moraine deposits. End moraines are present at the very southwestern end of Delavan Lake, southwestward to the basin divide, and in two small loca- 
tions about $1 \mathrm{mi}^{2}$ (square mile) in size near the central part of the basin. The rest of the basin is ground moraine.

The predominant surface bedrock in the basin is undifferentiated dolomites of Silurian age in the western one-third of the basin, Maquoketa Shale of Ordovician age in the central part of the basin, and undifferentiated rocks (mostly dolomite) of Ordovician age in the eastern one-third of the basin. The Cambrian sandstone underlies the Ordovician and Silurian rocks that overlie the crystalline, Precambrian rocks. The Maquoketa Shale is a barrier to vertical ground-water movement.

Water-bearing sand and gravel is present throughout much of the basin. It may extend down from the surface or be buried below relatively impermeable materials (fig. 2). The saturated thickness of the unconsolidated deposits ranges from $100 \mathrm{ft}$ in the northeastern part of the basin to $400 \mathrm{ft}$ in the southwestern part of the basin.

\section{Soils}

Soils in the Delavan Lake basin are clay loams, silty clay loams, and sandy clay loams and are described by Haszel (1971). There are three soil associations in the Delavan Lake basin: Pella-Kendall-Elburn, Miami-McHenry, and the

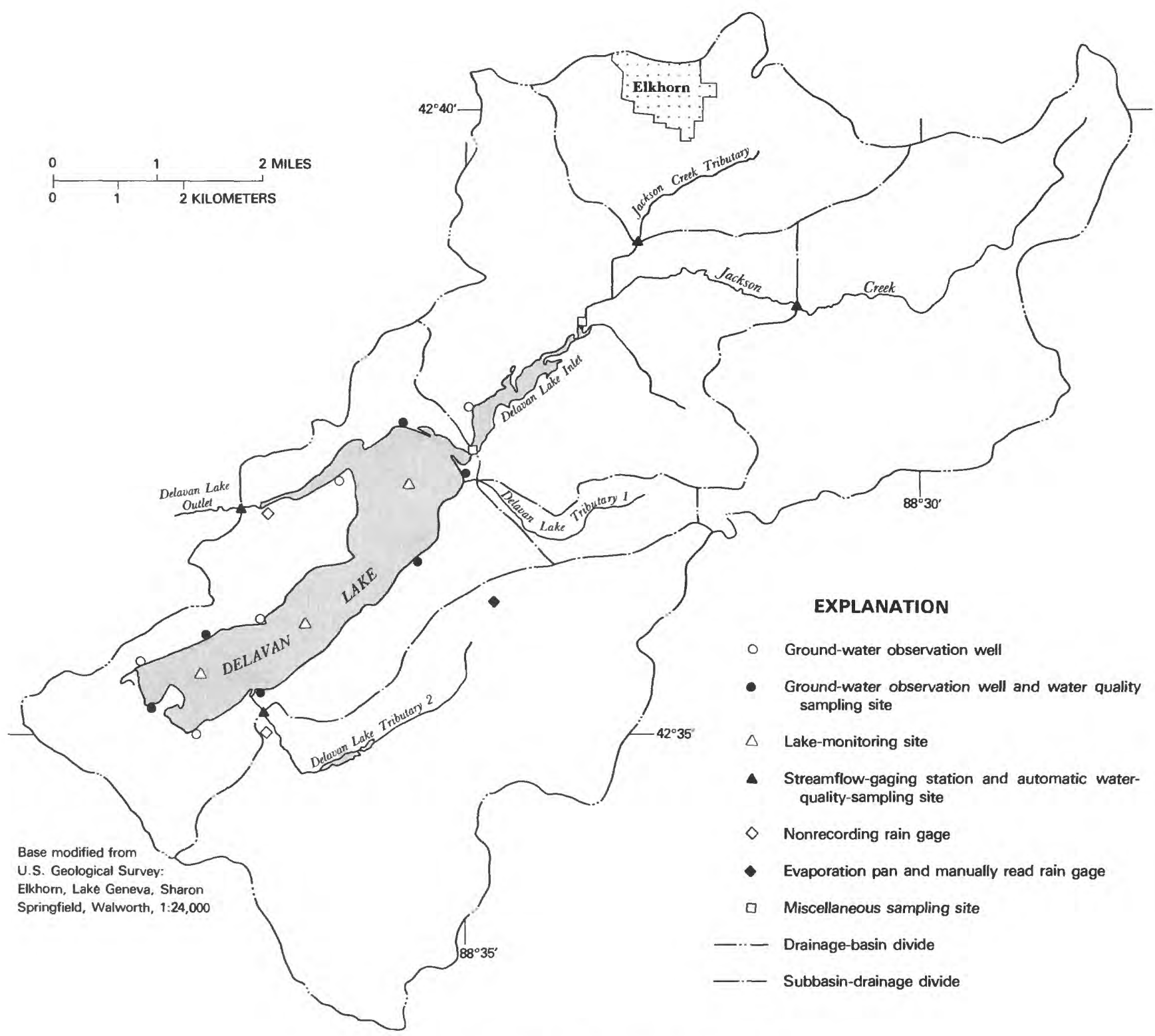

Figure 1. Delavan Lake drainage basin and monitoring sites. 
Table 1. Characteristics of Delavan Lake

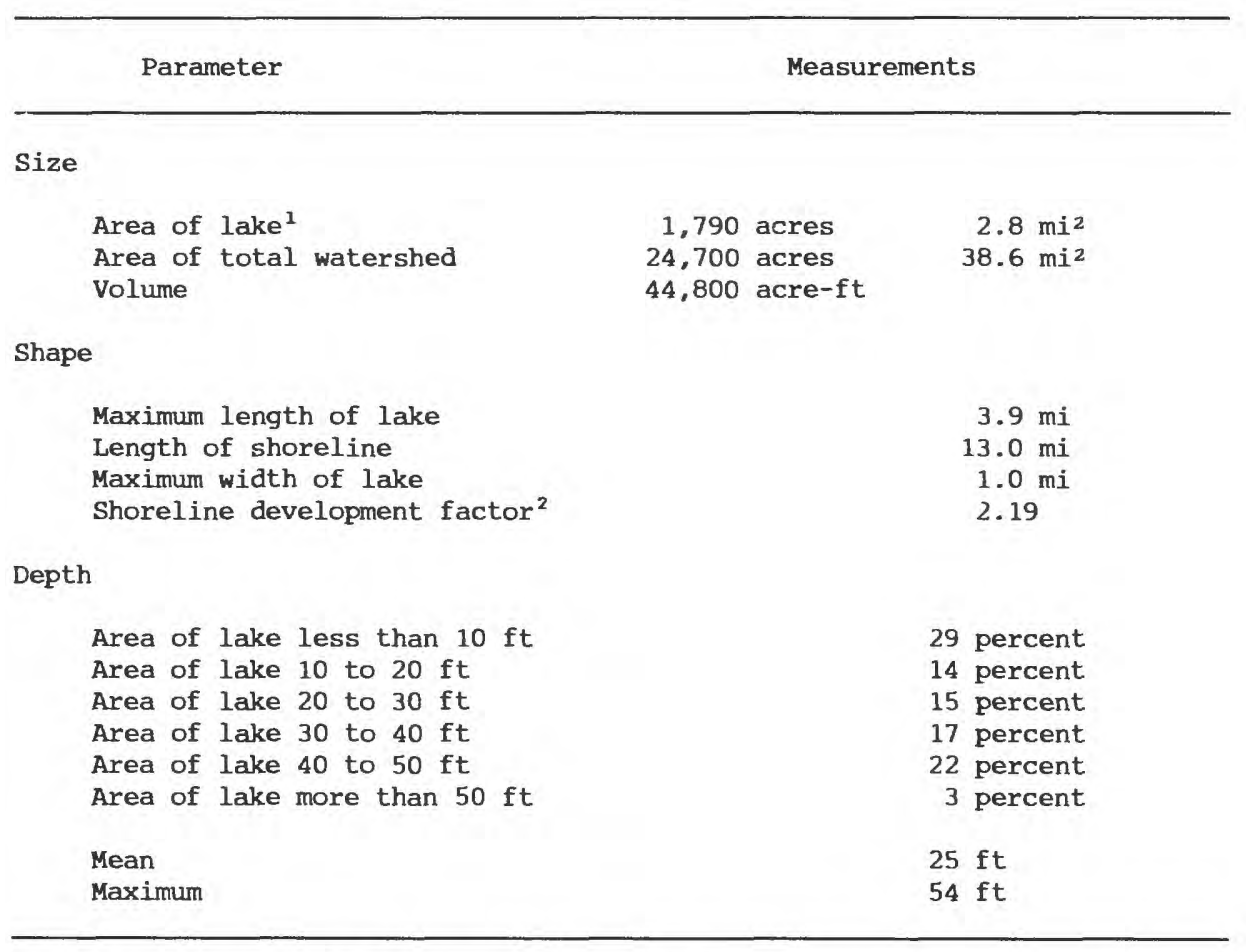

\footnotetext{
${ }^{1}$ Area determined from U.S. Geological Survey topographic maps. This area does not include Delavan Lake inlet but does include the surface area of the lake to the dam outlet.

${ }^{2}$ The ratio of the length of the shoreline to the circumference of a circle equal to that of the lake (Wetzel, 1983).
}

Plano-Griswold (fig. 2). The Pella-Kendall-Elburn association consists of poorly drained and somewhat poorly drained soils that line a subsoil of silty clay loam. The MiamiMcHenry association are well-drained soils that have a subsoil of clay loam and silty clay loam. The Plano-Griswold associations are well-drained soils that have a subsoil of silty clay loam and sandy clay loam.

\section{Land Use}

Agriculture is the principal land use in the Delavan Lake basin (table 2) (R. S. Grant, Southeastern Wisconsin Regional Planning Commission, written commun., 1985). The percentage of row crops, grain crops, and hay ranges from 50 percent in the shoreline drainage subbasin to 89 percent in the Jackson Creek subbasin (fig. 3). The percentage of woodland is low; 7 percent is the maximum amount in the Delavan Lake tributary No. 2 subbasin. Streets and highways are most dense in the Jackson Creek tributary basin ( 7 percent), which drains the city of Elkhorn. The largest amount of impervious area is found in the shoreline drainage around Delavan Lake (19 percent); the second largest amount (12 percent) is found in the Jackson Creek tributary subbasin. The largest amount of land used for retail, commercial, and manufacturing areas is found in the Jackson Creek tributary subbasin.

\section{DATA COLLECTION AND METHODS OF ANALYSIS}

Water-quality samples collected from Delavan Lake and its tributaries were analyzed by several means. Chemical analyses of water samples were performed by the U.S. Geological Survey central laboratory using standard analytical methods described by Fishman and Friedman (1985). Analyses for dissolved constituents were performed on samples that were filtered in the field through a $.45 \mu \mathrm{m}$ (micrometer) filter. Analyses for total or total recoverable constituents were performed on raw water samples. Preservation and shipment of samples followed standard protocols established by the laboratory. Suspended-sediment concentration analyses were performed by the U.S. Geological Survey sediment lab in Iowa City, Iowa.

\section{STREAMFLOW}

Water inflow to and outflow from the lake was measured at four locations (fig. 1). Inflow sites were Jackson Creek tributary near Elkhorn, Jackson Creek near Elkhorn, and Delavan Lake tributary 2 at South Shore Drive. The lake outflow was monitored $0.1 \mathrm{mi}$ downstream from the dam.

At the major inflow site of Jackson Creek through Delavan Lake inlet at State Highway 50 it was not possible 


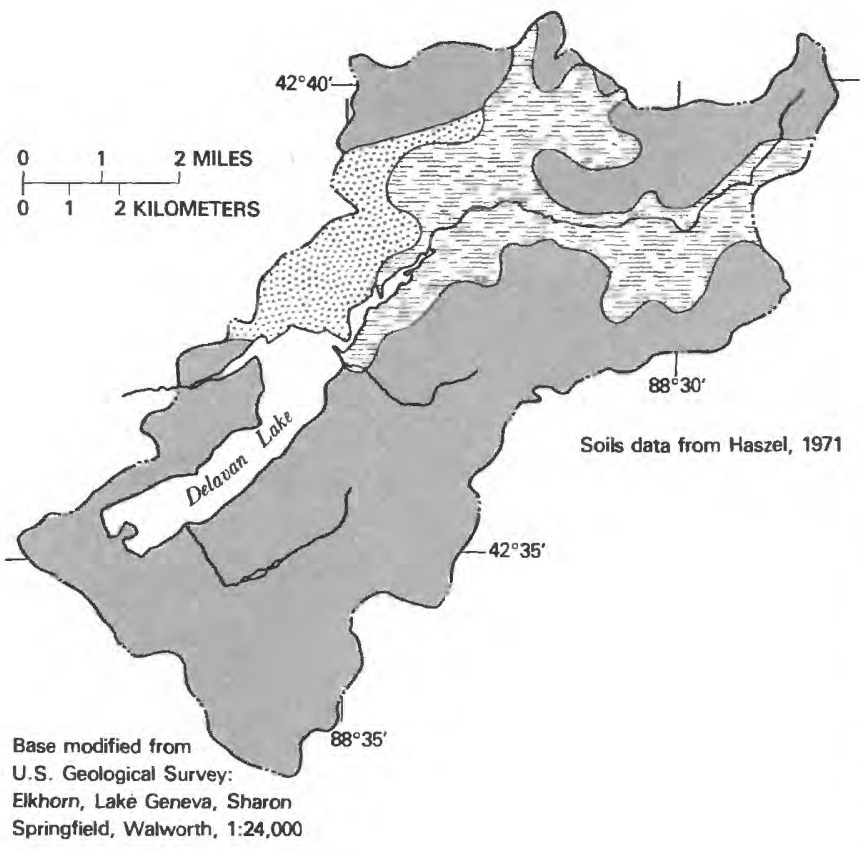

EXPLANATION

Pella-Kendall-Elburn association (poorly-drained and somewhat-poorly-drained soils)

Miami-McHenry association (well-drained soils)

Plano-Griswold association (well-drained soils) Drainage-basin divide

Figure 2. Soil associations.

to develop a stage-discharge relationship using conventional methods because of backwater from Delavan Lake. Discharge for this site was instead estimated by a drainagearea relationship with the upstream station of Jackson Creek near Elkhorn. The Jackson Creek near Elkhorn gaging station discharge was used because the land use in that basin is similar to that of the intervening area (see table 2).

Water samples were collected at all five sites for analysis of suspended-sediment concentration, and concentrations of nitrogen and phosphorus species. Three inflow stations were equipped with stage-activated, refrigerated, automatic Isco Model $1680^{1}$ samplers to collect storm runoff samples. Flowintegrated samples were collected manually using the equalwidth increment (EWI) method described by Guy and Norman (1970) at these and the other two sites. EWI samples collected at the times that samples were taken by the automatic samplers were used to develop coefficients to correct for concentration differences between point samples collected by the samplers and the more-representative flowintegrated samples. EWI samples were collected at low flow at all sites to estimate transport during low-flow periods. Nitrogen, phosphorus, and suspended-sediment loads at each monitoring station were computed using the integration method described by Porterfield (1972).

\section{GROUND WATER}

Thirteen shallow wells (average depth $10 \mathrm{ft}$ ) were drilled along the lakeshore for collection of quarterly water-level measurements and water samples for chemical analyses (fig. 1). Data were used to determine the direction of groundwater movement near the lake and to estimate the contribution of nutrients to the lake by ground water. Approximately 50 private wells in the basin also were used for quarterly water-level measurements to determine the direction of ground-water movement.

\section{PRECIPITATION AND EVAPORATION}

Precipitation quantity was monitored at three sites (fig. 1) during nonfreezing weather. Records from the National Weather Service station at Lake Geneva, $8 \mathrm{mi}$ to the southeast, were used when these stations were not operating (U.S. Department of Commerce, 1983, 1984, and 1985). Precipitation samples for chemical analysis were collected from a bulk precipitation collector at the DLSD location during the 1985 water year. These data were used to estimate nutrient contribution to the lake from precipitation.

Evaporation from the lake's surface was estimated using data from an evaporation pan installed at the DLSD office (fig. 1). This was read daily by their personnel during icefree periods.

\section{LAKE SAMPLING}

\section{Chemical and Physical Characteristics}

Three sites in the lake were sampled: one in the center of the lake at a depth of $54 \mathrm{ft}$, and the other two sites at a depth of $30 \mathrm{ft}$ at each end of the lake (fig. 1). Water-quality samples were collected with an Alpha Type or Kemmerer sampler, monthly from November through March and twice a month from April through October. Discrete samples were collected $3 \mathrm{ft}$ below the water surface and $2 \mathrm{ft}$ above the lakebed. Two additional samples were collected at each site during thermal stratification. Samples were collected at the center site in mid-June, mid-July, and early September every $6 \mathrm{ft}$ in the epilimnion and every $3 \mathrm{ft}$ in the metalimnion and hypolimnion.

Depth profiles of water temperature, dissolved oxygen, and $\mathrm{pH}$ were determined at all three sites using the sampling frequency described above using an Ocean Data Equipment Corporation meter. The meter was calibrated with known standards prior to lake sampling; dissolved oxygen was calibrated by the Winkler calibration method.

\section{Plankton}

Samples for phytoplankton and zooplankton were collected monthly from November through March and twice

\footnotetext{
${ }^{1}$ Use of the trade names in this report is for identification purposes only and does not constitute endorsement by the U.S. Geological Survey.
} 
Table 2. Land use in Delavan Lake basin ${ }^{1}$

[Drainage subbasin (in percent of subbasin)]

\begin{tabular}{|c|c|c|c|c|c|c|}
\hline Land use & Jackson Creek & $\begin{array}{c}\text { Jackson Creek } \\
\text { tributary }\end{array}$ & $\begin{array}{c}\text { Delavan Lake } \\
\text { inlet }^{2}\end{array}$ & $\begin{array}{l}\text { Delavan Lake } \\
\text { tributary } 2\end{array}$ & $\begin{array}{l}\text { Shoreline } \\
\text { drainage }\end{array}$ & $\begin{array}{l}\text { Delavan Lake } \\
\text { tributary } 1\end{array}$ \\
\hline Row crops & 69 & 55 & 66 & 76 & 48 & 62 \\
\hline Grain crops & 5 & 0 & 1 & 0 & 0 & 0 \\
\hline Hay & 15 & 2 & 5 & 4 & 2 & 7 \\
\hline Woodland & 3 & 0 & 4 & 4 & 1 & 7 \\
\hline \multicolumn{7}{|l|}{ Streets and } \\
\hline highways & 1 & 7 & 1 & 0 & 1 & 7 \\
\hline \multicolumn{7}{|l|}{ Residential } \\
\hline impervious & 0 & 12 & 3 & 2 & 19 & 8 \\
\hline \multicolumn{7}{|c|}{$\begin{array}{l}\text { Retail, comwercial, } \\
\text { utilities, }\end{array}$} \\
\hline manufacturing & 0 & 7 & 2 & 1 & 0 & 1 \\
\hline Other & 7 & 17 & 18 & 13 & 29 & 15 \\
\hline Subbasin total & $\overline{100}$ & $\overline{100}$ & $\overline{100}$ & $\overline{100}$ & $\overline{100}$ & $\overline{100}$ \\
\hline
\end{tabular}

\footnotetext{
${ }^{1}$ The data presented in this table were inventoried in 1975. In the other classification are: water, airfields, landfills and dumps, otber recreational, and other open spaces.

${ }^{2}$ Intervening area--upstream of Highway 50 and downstrean of Jackson Creek tributary gaging stations.
}

a month from April through October from the two ends of the lake (fig. 1). Samples for phytoplankton were collected from the upper 3-ft composite sample using a Kemmerer sampler and were preserved with $10 \mathrm{~mL} / \mathrm{L}$ (milliliters per liter) of Lugols solution. These samples were sent to Susswasser, Jan Brockson, P.O. Box 1255, Paso Robles, Calif., 93447, who performed the analyses. Samples for zooplankton were collected by towing a Wisconsin Plankton net, mesh size 153 microns through the oxgenated zone; only a single haul per site was used. These samples were preserved with an equal volume of 5 percent formalin solution and were sent to the firm of Susswasser, which performed the analyses from October 7, 1983, to March 13, 1984, and to GZT Associates, 435 Mammoth Oaks Drive, Charlotte, N.C. 28226 , for subsequent analyses.

\section{Benthic Invertebrates}

Benthic invertebrates were sampled in May and September during the 1984 and 1985 water years. Twelve sites in the lake were sampled (fig. 4) using a PONAR grab sampler; replicate samples were collected at most sites. Samples were preserved with an equal volume of 70 percent ethanol and identifications were made by Robert A. Lidwin, U.S. Geolozical Survey, Madison, Wisconsin.

\section{BOTTOM SEDIMENTS}

Bottom sediment cores were collected at the deep hole (54 ft deep) and in Delavan Lake inlet. Sediment cores were collected during winter using a freeze corer similar to one described by Walkotten (1976). The freeze corer is an aluminum tube approximately $5 \mathrm{ft}$ long and 2 in. (inch) in diameter with a pointed lead plug at one end. The corer was weighted with lead and then filled with pelletized dry ice and ethanol. The corer was plugged at the top with a rubber stopper and dropped into the sediments. The corer remained in the sediment for approximately 5 minutes to allow the dry ice to freeze the sediment around the corer. The corer was raised to the surface and the frozen sediment around the outside of the corer was removed by emptying the dry ice from the tube and filling the tube with lake water. The water loosened the sediment around the tube until the sediment could slide over the end of the corer. The frozen sediment was wrapped in aluminum foil, labeled, and placed in a cooler with dry ice. The cores were then sliced with a steel band saw into individual cores for analyses.

The Delavan Lake inlet was surveyed to determine the depth of its soft sediment. The survey was conducted by applying the weight of one person [approximately $175 \mathrm{lb}$ (pounds)] to a 1 -in. diameter probe at 10 to 20 points in 21 cross sections.

\section{HYDROLOGY}

\section{PRECIPITATION}

Precipitation for the 1984 and 1985 water years is shown in table 3 . Annual precipitation in the 1984 water year was 


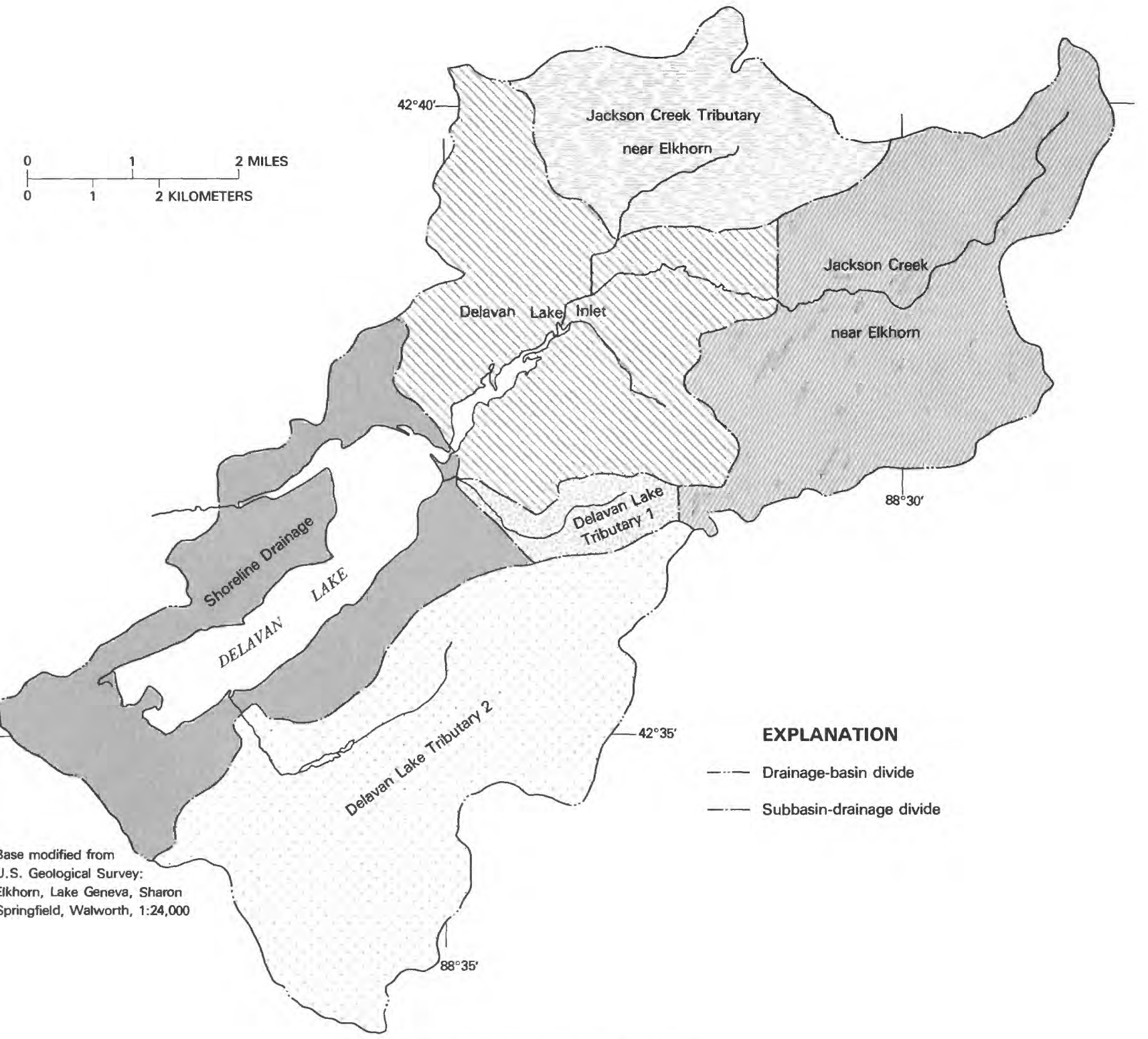

Figure 3. Delavan Lake subbasins.

$32.0 \mathrm{in}$. and in the 1985 water year it was $38.9 \mathrm{in}$. based on data from the three nonrecording precipitation stations around the lake (fig. 1) during nonfreezing periods and the data from Lake Geneva during freezing periods. Average annual precipitation for Delavan Lake is 31.6 in. based on the long-term average from the National Weather Service station at Whitewater, $16 \mathrm{mi}$ northwest of the lake.

\section{EVAPORATION}

Evaporation from the lake surface during the 1984 and 1985 water years was calculated as 27.45 and 32.98 in., based on evaporation pan data and the mass-transfer method (Dunne and Leopold, 1978; Winter, 1981). Monthly evaporation pan readings obtained by personnel from the sanitary district and evaporation pan data at the National Weather Service station located at Madison, $60 \mathrm{mi}$ to the northwest of Delavan Lake, are shown in table 4. An an- nual pan coefficient of 0.77 was used to determine the evaporation from the lake surface (U.S. Department of Commerce, 1982). For those months (except October 1983) when evaporation pan data were unavailable, estimates were made using the mass-transfer method.

\section{STREAMFLOW}

Summaries of the streamflow characteristics for the Delavan Lake basin and Turtle Creek gaging stations are shown in table 5. Daily discharge data for these stations, excluding Delavan Lake inlet, are published in the U.S. Geological Survey annual data publication (Holmstrom and others, 1985, 1986).

The Turtle Creek gaging station is located $21 \mathrm{mi}$ downstream from the Delavan Lake outlet. Its 45 -year record was used to compare the streamflow data from the gaging stations in the Delavan Lake basin. 
Table 3. Precipitation at Delavan Lake and Lake Geneva, 1984 and 1985 water years

\begin{tabular}{|c|c|c|c|c|}
\hline & \multicolumn{2}{|c|}{1984 water year } & \multicolumn{2}{|c|}{1985 water year } \\
\hline & Delavan Lake & Lake Geneva & Delavan Lake & Lake Geneva \\
\hline October & ${ }^{1} 3.31$ & 3.31 & 6.37 & 5.51 \\
\hline November & 2.96 & 3.73 & 3.72 & 3.55 \\
\hline December & ${ }^{1} 3.14$ & 3.14 & ${ }^{1} 3.16$ & 3.16 \\
\hline January & ${ }^{1} 1.31$ & 1.31 & ${ }^{1} 2.52$ & 2.52 \\
\hline February & ${ }^{1} 1.63$ & 1.63 & ${ }^{1} 1.67$ & 1.67 \\
\hline March & 1.28 & 2.12 & ${ }^{1} 2.99$ & 2.99 \\
\hline April & 3.17 & 4.17 & ${ }^{1} 1.38$ & 1.38 \\
\hline May & 4.85 & 5.09 & 3.22 & 3.29 \\
\hline June & 3.78 & 3.36 & 1.85 & 2.49 \\
\hline July & 2.14 & 2.86 & 5.08 & 5.57 \\
\hline August & 1.15 & 1.37 & 3.72 & 3.20 \\
\hline \multirow[t]{2}{*}{ September } & 3.29 & 4.30 & 3.19 & 2.94 \\
\hline & $\overline{32.01}$ & $\overline{36.39}$ & $\overline{38.87}$ & $\overline{38.27}$ \\
\hline
\end{tabular}

${ }^{1}$ Used Lake Geneva data.

Table 4. Evaporation data for Delavan Lake, 1984 and 1985 water years

\begin{tabular}{|c|c|c|c|c|c|c|}
\hline & \multicolumn{3}{|c|}{$\begin{array}{c}\text { Evaporation pan data, } \\
1984 \text { water year } \\
\text { (in inches) }\end{array}$} & \multicolumn{3}{|c|}{$\begin{array}{c}\text { Evaporation pan data, } \\
1985 \text { water year } \\
\text { (in inches) }\end{array}$} \\
\hline & Delavan & Madison & Estimated ${ }^{2}$ & Delavan & Madison & Estimated $^{2}$ \\
\hline October & ${ }^{1} 2.52$ & 2.77 & & 3.35 & 2.14 & \\
\hline November & & & 0.25 & & & 0.97 \\
\hline December & & & 1.00 & & & .43 \\
\hline January & & & .19 & & & .54 \\
\hline February & & & .35 & & & .39 \\
\hline March & & & .61 & & & .65 \\
\hline April & & & .59 & 5.38 & & \\
\hline May & 3.42 & 5.62 & & 7.30 & 8.67 & \\
\hline June & 7.71 & 7.26 & & 5.08 & 7.89 & \\
\hline July & 7.38 & 7.31 & & 8.42 & 8.61 & \\
\hline August & 6.38 & 6.37 & & 5.49 & 5.94 & \\
\hline September & 4.36 & 5.02 & - & 3.94 & 3.78 & 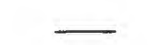 \\
\hline Total & 31.77 & & & 38.96 & & \\
\hline $\begin{array}{l}\text { Pan } \\
\text { coefficient }\end{array}$ & $\mathrm{x} 0.77$ & & & $\times \quad 0.77$ & & \\
\hline Evaporation & 24.46 & & 2.99 & 30.00 & & 2.98 \\
\hline $\begin{array}{l}\text { Total annual } \\
\text { evaporation }\end{array}$ & 27.45 & & & 32.98 & & \\
\hline
\end{tabular}

${ }^{1}$ Estimate based on 9 percent reduction comparing Delavan evaporation pan data to Madison for those months when both months' data were available.

${ }^{2}$ Estimated using methods by Dunne and Leopold (1978) and Winter (1981). 


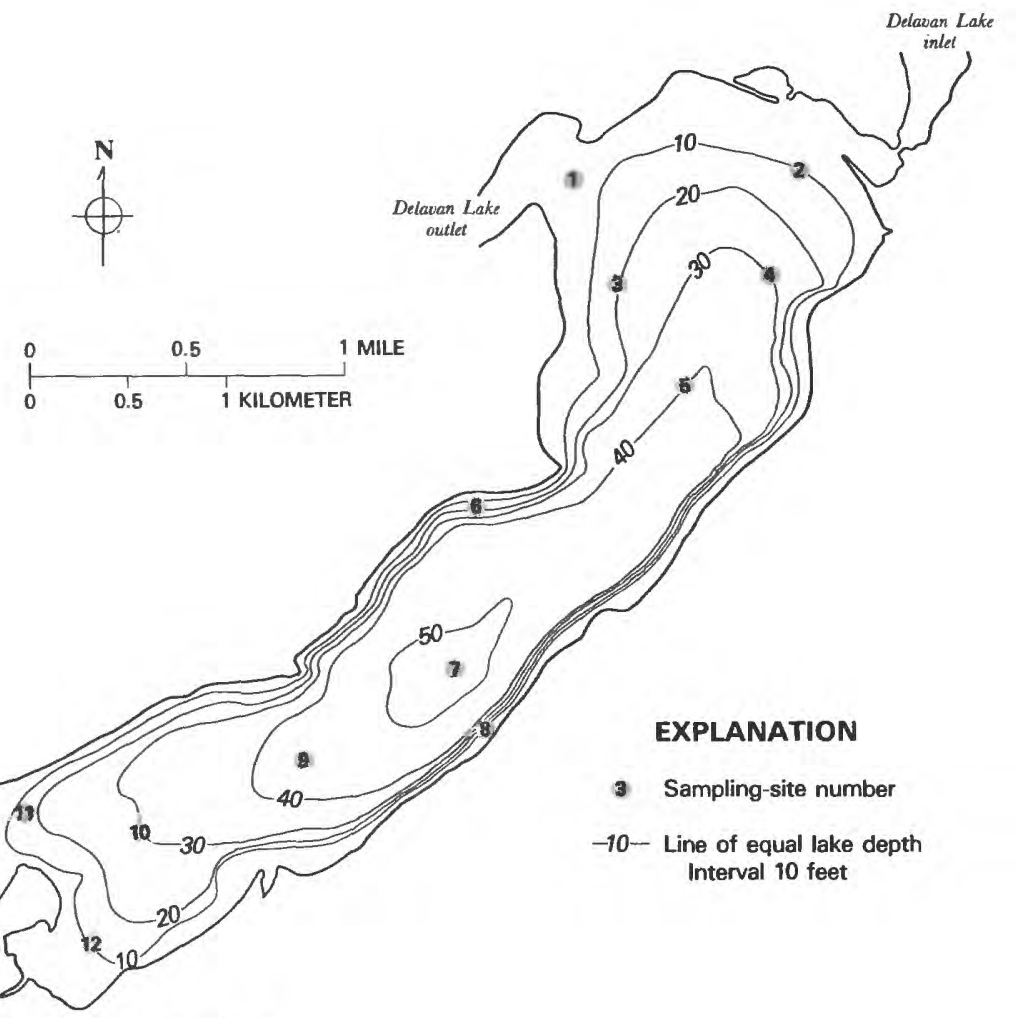

Base modified from U.S. Geological Survey:

Sharon, Walworth, Elkhorn, 1:24,000

Figure 4. Bathymetric map of Delavan Lake showing benthic-macroinvertebrate sampling sites.

Table 5. Summary of streamflow characteristics for Delavan Lake basin and Turtle Creek at Clinton gaging stations [ $\mathrm{mi}^{2}$, square miles; $\left(\mathrm{ft}^{3} / \mathrm{s}\right)-\mathrm{d}$, cubic feet per second days; a dash indicates data unavailable]

\begin{tabular}{|c|c|c|c|c|c|c|c|c|c|}
\hline Station name & Pear & $\begin{array}{c}\text { Drainage } \\
\text { area } \\
\left(\mathrm{mi}^{2}\right)\end{array}$ & $\begin{array}{c}\text { Total }^{1} \\
\text { discharge } \\
{\left[\left(\mathrm{ft}^{3} / \mathrm{s}\right)-\mathrm{d}\right]}\end{array}$ & $\begin{array}{c}\text { Mean daily } \\
\text { discharge } \\
\left(\mathrm{ft}^{3} / \mathrm{s}\right)\end{array}$ & $\begin{array}{l}\text { Maximum } \\
\text { daily mean } \\
\text { discharge } \\
\left(\mathrm{ft}^{3} / \mathrm{s}\right)\end{array}$ & $\begin{array}{l}\text { Maximum } \\
\text { instantaneous } \\
\text { discharge } \\
\left(\mathrm{ft}^{3} / \mathrm{s}\right)\end{array}$ & $\begin{array}{l}\text { Minimum } \\
\text { daily mean } \\
\text { discharge } \\
\left(\mathrm{ft}^{3} / \mathrm{s}\right)\end{array}$ & $\begin{array}{c}\text { Mean } \\
\text { discharge } \\
{\left[\left(\mathrm{ft}^{3} / \mathrm{s}\right) / \mathrm{mi}^{2}\right]}\end{array}$ & $\begin{array}{r}\text { Runoff } \\
\text { (inches) }\end{array}$ \\
\hline \multirow[t]{2}{*}{ Jackson Creek } & 1984 & \multirow{2}{*}{8.96} & 1,600 & 4.36 & 135 & 177 & 0.07 & 0.49 & 6.62 \\
\hline & 1985 & & 1,600 & 4.39 & 80 & 103 & .10 & .49 & 6.66 \\
\hline \multirow{2}{*}{$\begin{array}{c}\text { Jackson Creek } \\
\text { tributary }\end{array}$} & 1984 & \multirow{2}{*}{4.34} & 1,100 & 2.99 & 56 & 108 & .39 & .69 & 9.40 \\
\hline & 1985 & & 1,500 & 4.11 & 60 & 129 & .25 & .95 & 12.9 \\
\hline \multirow{2}{*}{$\begin{array}{l}\text { Delavan Lake } \\
\text { inlet }\end{array}$} & 1984 & \multirow{2}{*}{21.8} & 4,230 & 11.6 & 310 & -- & .53 & .53 & 7.23 \\
\hline & 1985 & & 4,630 & 12.7 & 216 & -- & .46 & .58 & 7.91 \\
\hline \multirow{2}{*}{$\begin{array}{l}\text { Delavan Lake } \\
\text { tributary } 2\end{array}$} & 1984 & \multirow{2}{*}{9.99} & 597 & 1.63 & 17 & 18 & .23 & .21 & 2.90 \\
\hline & 1985 & & 509 & 1.40 & 15 & 22 & .15 & .18 & 2.47 \\
\hline \multirow{2}{*}{$\begin{array}{l}\text { Delavan Lake } \\
\text { outlet }\end{array}$} & 1984 & \multirow{2}{*}{42.1} & 7,690 & 21.0 & 128 & 134 & .41 & .53 & 7.19 \\
\hline & 1985 & & 9,050 & 24.8 & 88 & 163 & .18 & .62 & 8.47 \\
\hline \multirow{2}{*}{$\begin{array}{r}\text { Turtle Creek } \\
\text { at Clinton }\end{array}$} & 1984 & \multirow{2}{*}{199} & 54,200 & 148 & 1,110 & 1,190 & 62 & .74 & 10.2 \\
\hline & 1985 & & 58,700 & 161 & 960 & 1,100 & 60 & .81 & 11.1 \\
\hline $\begin{array}{r}\text { Turtle Creek } \\
\text { at Clinton }\end{array}$ & $\begin{array}{l}\text { Period } \\
\text { of } \\
\text { record }\end{array}$ & & & 122 & & 16,500 & & & 8.33 \\
\hline
\end{tabular}




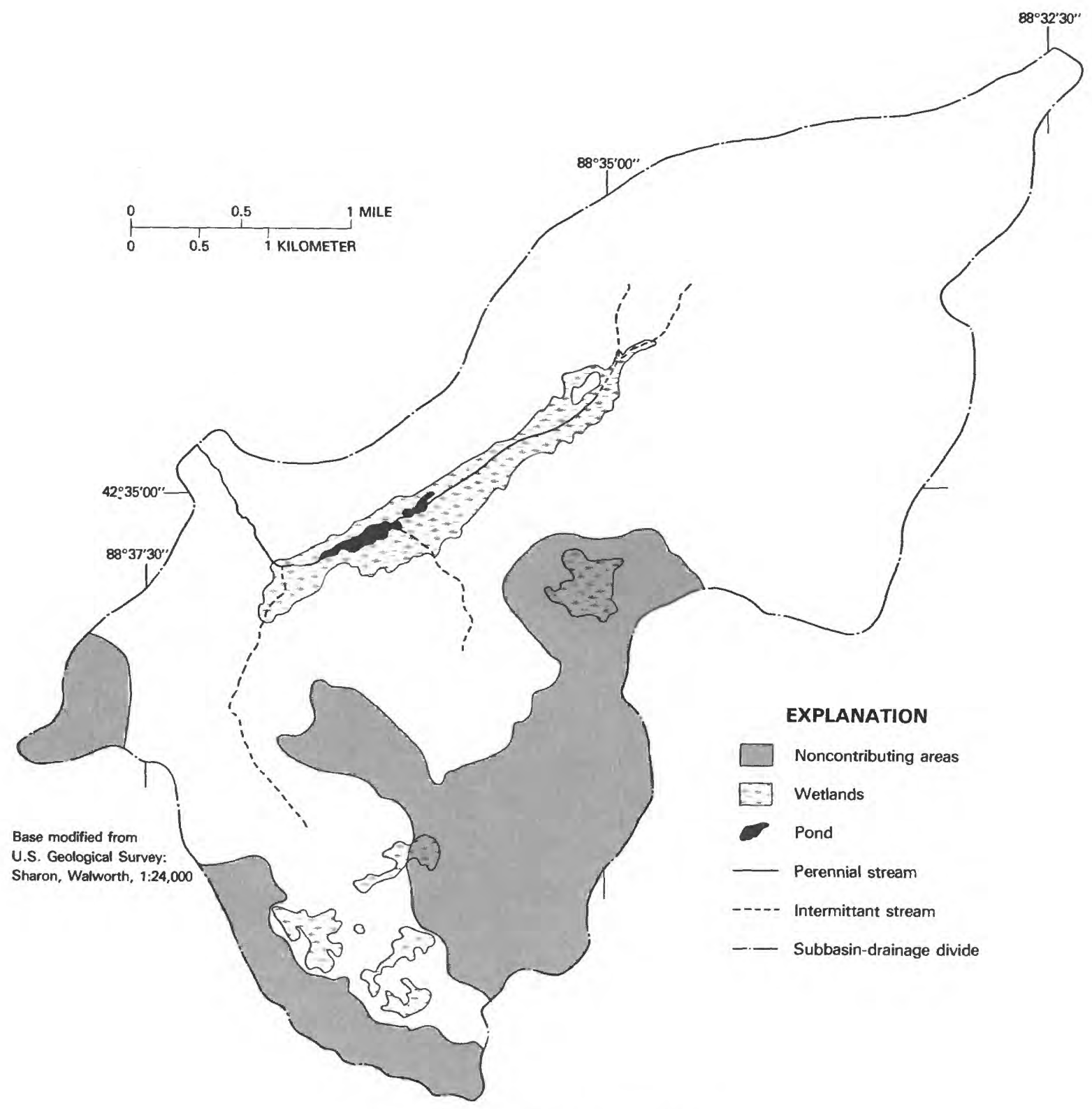

Figure 5. Delavan Lake tributary 2 basin.

Annual streamflow in the Delavan Lake basin, based on the Turtle Creek gaging station records for the 1984 water year, was 21 percent greater than average; in the 1985 water year it was 32 percent greater. The greater than average discharges in 1985 can be explained by the 7.2 in. greater than average precipitation and higher than average groundwater levels for the past several years (see fig. 9 in the section "Ground Water"). Greater than average precipitation can result in greater than average runoff. High ground-water levels increase the base flow of streams and thus increase the total streamflow for the year. These greater than normal ground-water levels may also have caused the above-normal stream discharges in the 1984 water year despite normal precipitation for the year.

Streamflow maximums for both years were not excessively high as indicated by the maximum instantaneous discharge at Turtle Creek shown in table 5. The mean annual flood for Turtle Creek is $2,160 \mathrm{ft}^{3} / \mathrm{s}$ (cubic feet per second) (Conger, 1981). The maximum instantaneous streamflow in the 1984 water year was about 50 percent of the mean annual flood calculated for this station whereas the 1985 water year maximum was only slightly greater than the mean annual flood.

It is important to note the amount of variation in runoff (table 5) between the various subbasins of the Delavan Lake basin. Runoff, in inches, indicates the depth of water that would cover a drainage area if all streamflow for a given time period were uniformly distributed. The average runoff for the Delavan Lake basin is 8.33 in. using the long-term average of the Turtle Creek gaging station record as an index. Runoff is lowest in the Delavan Lake tributary 2 basin, averaging $2.68 \mathrm{in}$. for the 2-year period and highest in the Jackson Creek tributary basin, averaging 11.1 in.

The low annual runoff from the Delavan Lake tributary 2 basin is indirectly caused by the basin's topography and vegetative cover. The southern part of the basin is end moraine material with a rolling to hummocky surface with several noncontributing areas (fig. 5). Noncontributing areas 


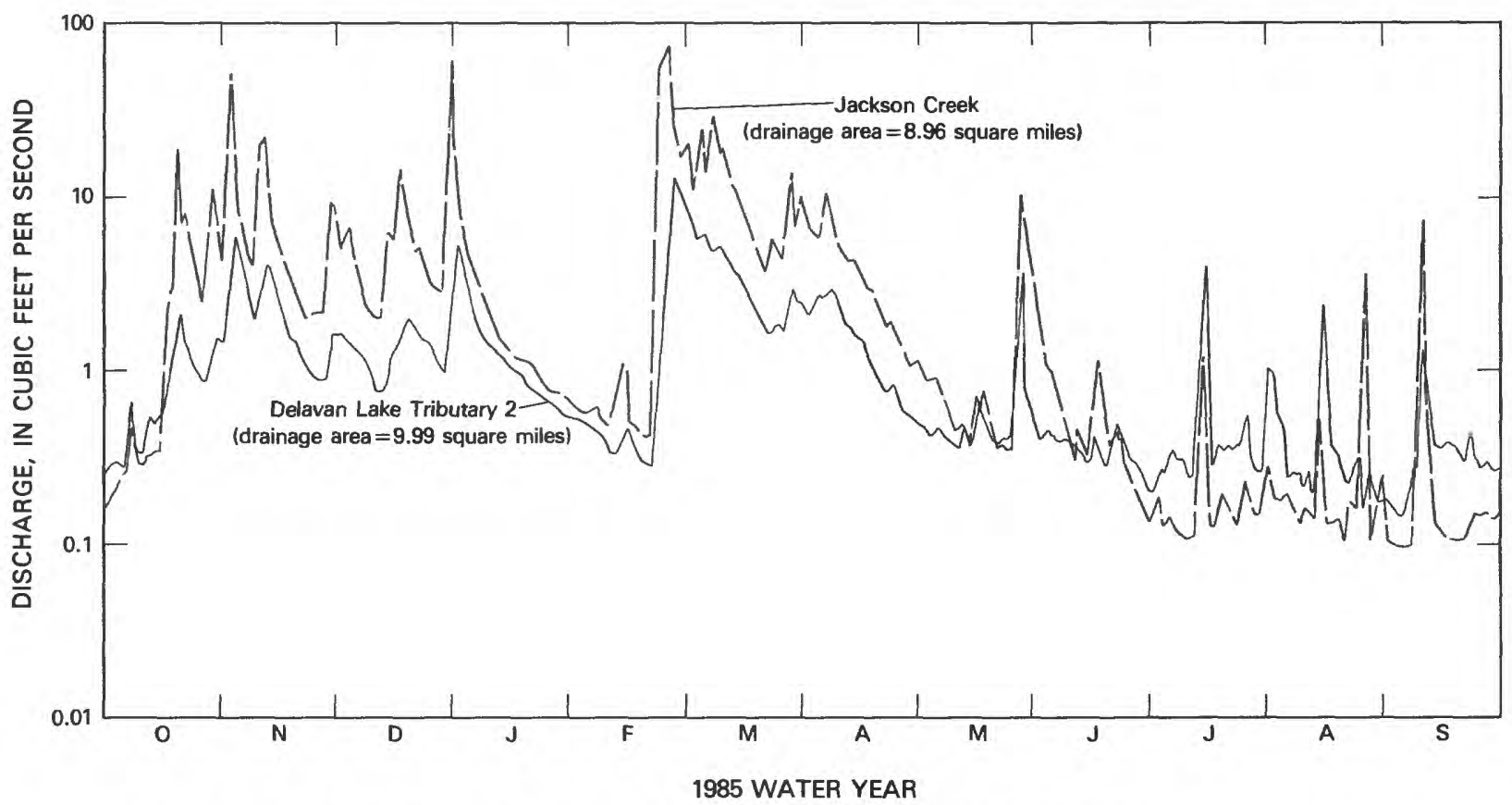

Figure 6. Discharge of Delavan Lake tributary 2 and Jackson Creek, 1985 water year.

are internally drained and do not contribute to surface runoff. Noncontributing areas in this basin compose $2.33 \mathrm{mi}^{2}$, or 23 percent of the basin. The basin also contains numerous wetland areas; a large wetland about $2 \mathrm{mi}$ long and $0.25 \mathrm{mi}$ wide near the downstream end of the basin drains most of the surface runoff. It is likely that much evapotranspiration occurs from these wetlands.

The effect of the topography and wetlands on the reduction in surface runoff is illustrated in figure 6 by comparing the 1985 water year hydrographs of Delavan Lake tributary 2 (drainage area $=9.99 \mathrm{mi}^{2}$ ) and Jackson Creek (drainage area $=8.96 \mathrm{mi}^{2}$ ). The Jackson Creek gaging station records much higher peak flows than that of the Delavan Lake tributary station.

The basin with the highest annual runoff is the Jackson Creek tributary basin. This basin drains the city of Elkhorn and contains the greatest percentage of streets and highways (7 percent) and impervious residential areas (12 percent) of the three inflow monitoring sites. These impervious areas cause greater runoff.

\section{GROUND WATER \\ Occurrence}

Ground water occurs in saturated sediment deposits that range in thickness from $100 \mathrm{ft}$ in the northeastern part of the basin to $400 \mathrm{ft}$ in the southwestern part of the basin (Borman, 1976). Depth to the water table varies from 0 to 10 $\mathrm{ft}$ near the wetlands and lakes to $125 \mathrm{ft}$ below the hills.

\section{Movement}

Ground water moves from areas of recharge to areas of discharge. The rate at which ground water is replenished depends on the amount and intensity of precipitation, the infiltration capacity of the soil, and the permeability of the underlying materials. The regional gradient of the groundwater table in the Delavan Lake basin, although complex, is generally from the southeast to northwest (fig. 7). The contour lines in figure 7 were drawn based on the data from the $\mathbf{1 3}$ ground-water sampling wells close to the lake and $\mathbf{5 0}$ private wells scattered throughout the basin.

The 13 shallow ground-water wells near the lake's edge were used to determine the direction of ground-water movement around Delavan Lake (fig. 7). The relationship between the water surface in these wells to the lake surface elevation is shown in figure 8. The datum for these wells and lake surface in the illustration is at $922.92 \mathrm{ft}$ above mean sea level. Well numbers 1 and 7-11 all show generally positive gradients or ground-water movement toward Delavan Lake (fig. 8, upper graph). Water levels in some wells were at or below the lake surface (fig. 8, lower graph). Well number 5 is the only well that shows nearly consistent movement away from the lake. The water depths for well numbers 4 in April 1984 and 6 in November 1984 may be anomalous data.

Water-level fluctuations in wells in and near the Delavan Lake basin are shown in figure 9 . Well number $W w-9$ is located about $7 \mathrm{mi}$ northwest of Delavan Lake and is a drilled artesian well in Galena dolomite of Silurian age $287 \mathrm{ft}$ deep. Figure 9 shows that ground-water levels during the 2-year study period were above the normal for the 40-year longterm record. Water-level fluctuations in the wells in the Delavan Lake basin show about a 4-ft fluctuation during the 2-year study period.

Ground-water discharge to the lake was based on periods when the lake was ice covered and evaporation was minimal. Recharge to the ground-water system from the lake was considered negligible because most of the shallow ground-water 


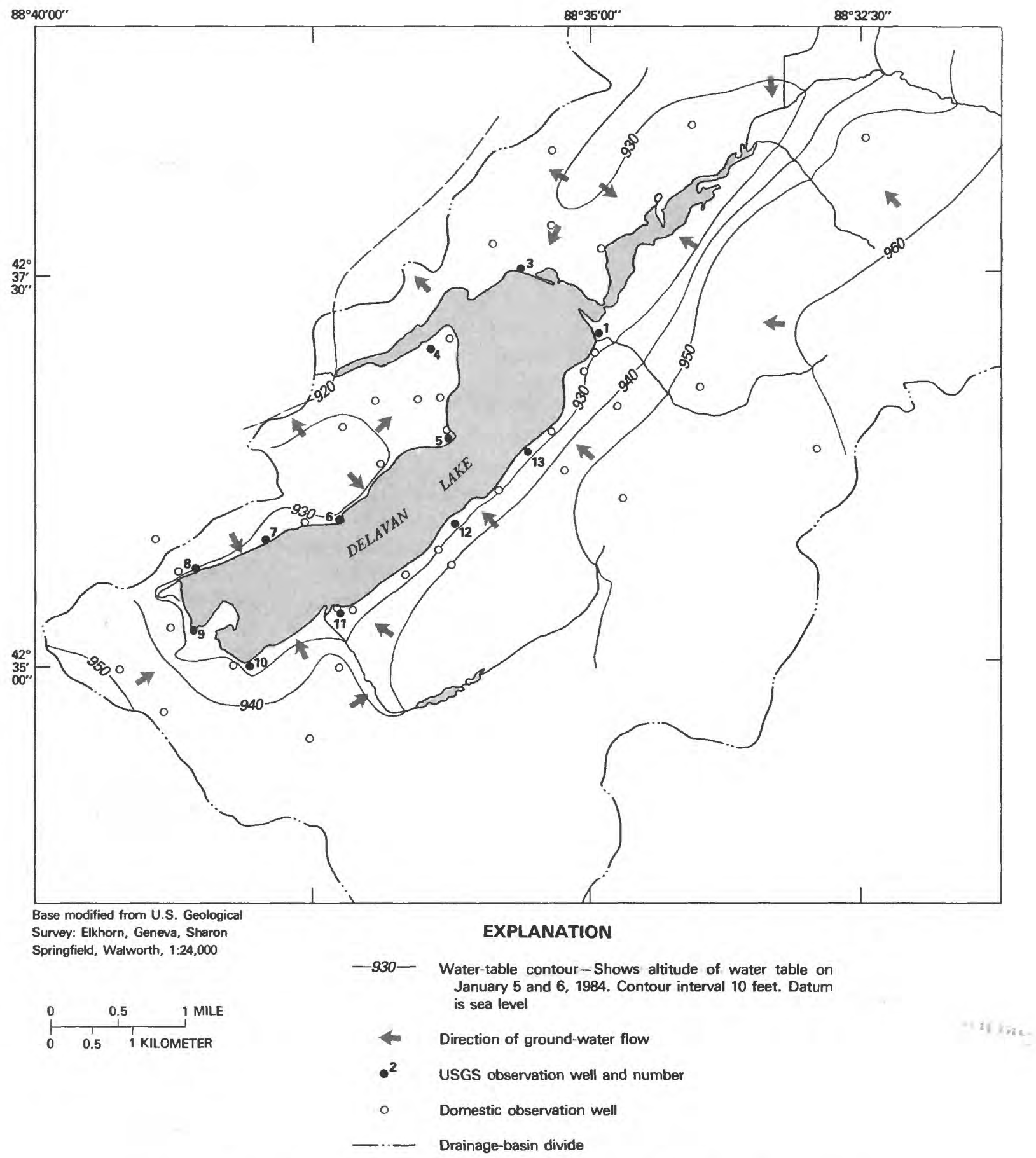

Figure 7. Generalized regional water-table configuration and ground-water movement. 

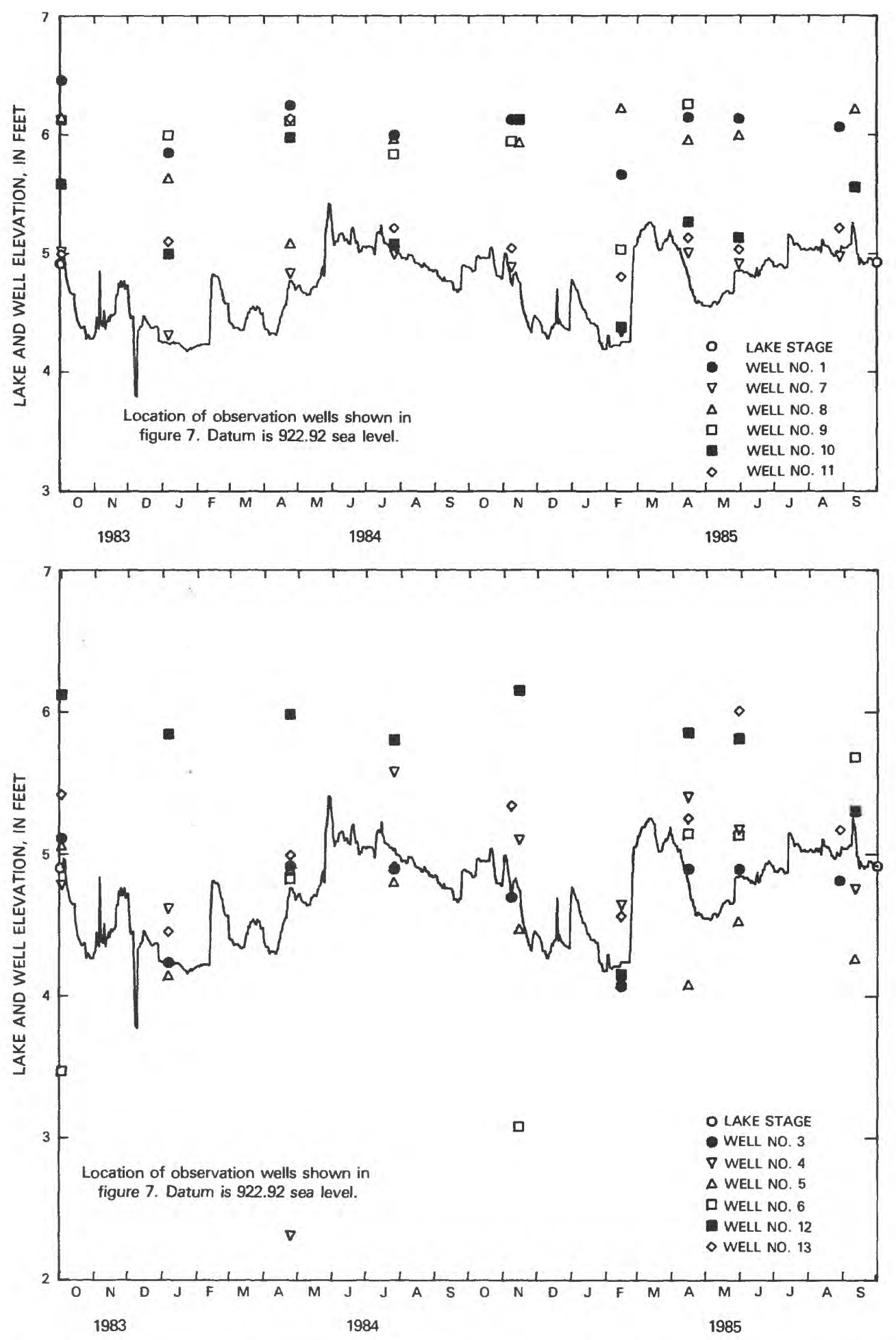

Figure 8. Relation between water level in wells within 10 feet of Delavan Lake's shoreline and the lake's water surface. 
WELL No. Ww-9 (287 feet deep)

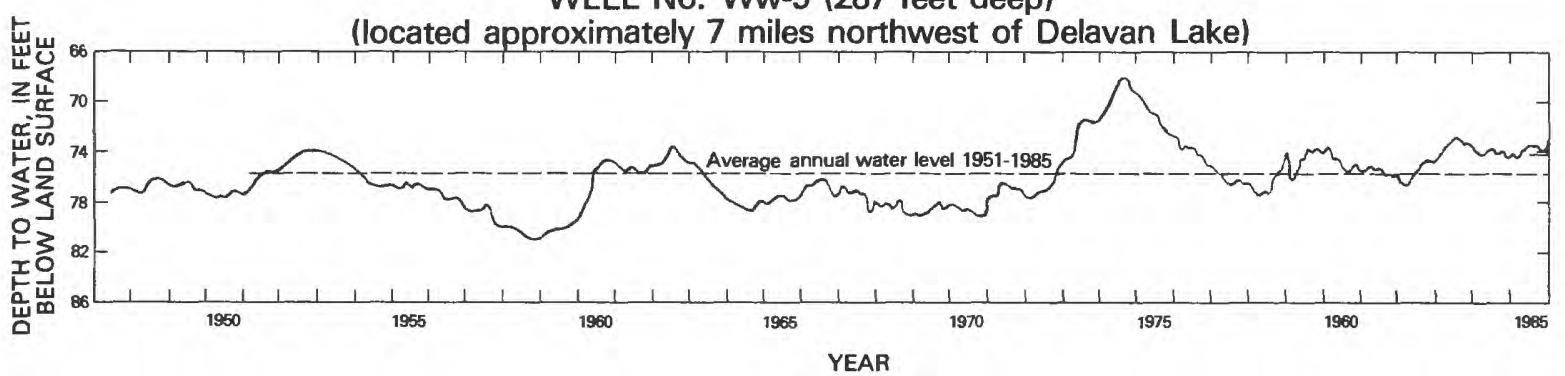

Well No. 37

(108 feet deep)

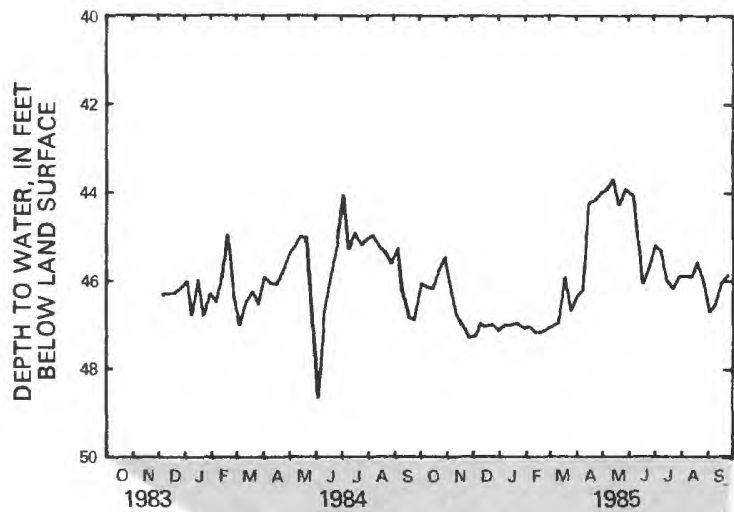

Well No. 21

(157 feet deep)

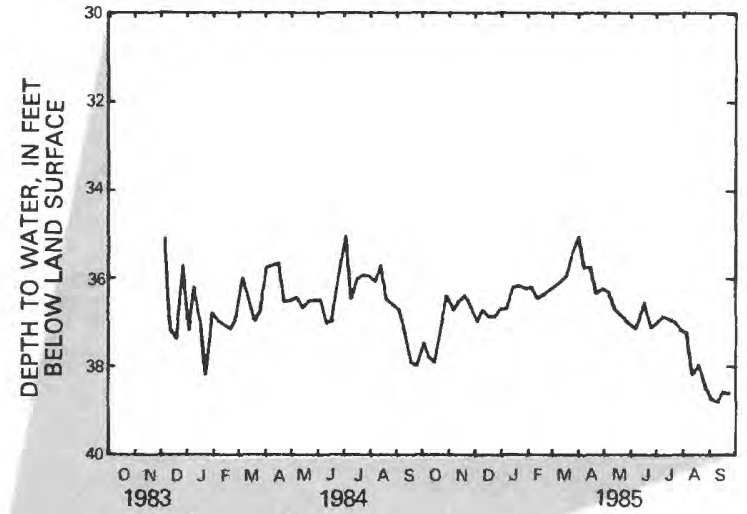

Well No. 17

(depth unknown)

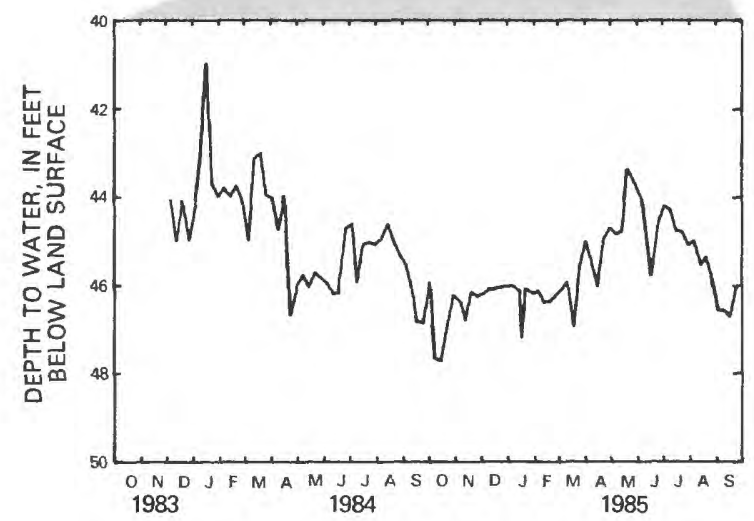

D. L. S. D. WATER LEVEL 30

(46 feet deep)

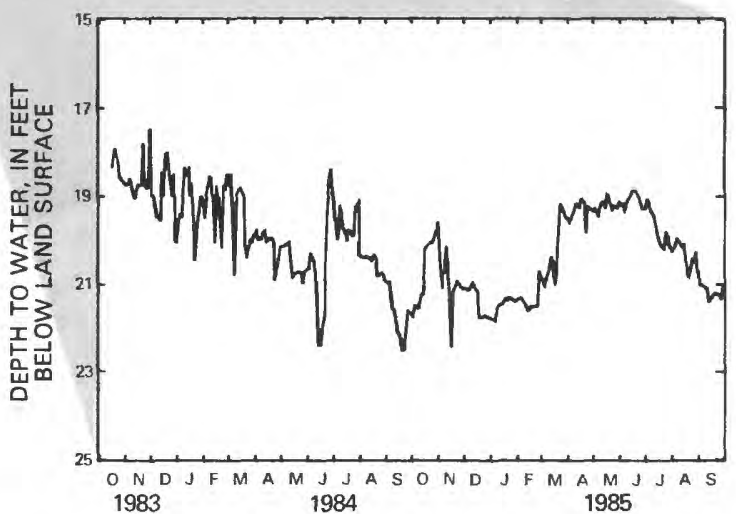

Figure 9. Water-level fluctuations in ground-water wells in and near Delavan Lake basin. 
wells near the lake's edge show that ground water discharges to the lake.

Ground-water discharge to the lake was estimated using the following equation:

Ground-water discharge $=$ change in lake storage - precipitation + (streamflow out -streamflow in)

Ground-water discharge to the lake in the 1984 water year was computed based on the period January 22 to February 8 and averaged $5.0 \mathrm{ft}^{3} / \mathrm{s}$. In the 1985 water year it was computed based on the period February 1-8 and was averaged $7.9 \mathrm{ft}^{3} / \mathrm{s}$. During these periods the streamflow was determined by streamflow measurements and discharge records at the gaging stations.

\section{LAKE STAGE}

Water-level fluctuations of lake stage were shown previously in figure 8; the datum of the gage is $922.92 \mathrm{ft}$ above sea level. Minimum levels occur in late fall or early winter when water levels are drawn down to prevent ice damage to shoreline structures during winter. Drawdown of the lake level is started about October and the lake is raised to pre-October levels starting in May (K. L. MacKinnon, DLSD, oral commun., 1985). In the 1984 water year the lake stage minimum was $3.78 \mathrm{ft}$ on December 9; in 1985 water year it was $4.18 \mathrm{ft}$ January 29-31 (table 6). The maximum lake stage in 1984 water year was $5.42 \mathrm{ft}$ on May 29; in the 1985 water year it was $5.26 \mathrm{ft}$ on March 11-13.

\section{HYDROLOGIC BUDGET}

The annual hydrologic budget for Delavan Lake is conceptualized as follows:

change in storage $=$ inflow - outflow

The budget can be rewritten as

$$
\text { change in storage }- \text { inflow }+ \text { outflow }=0
$$

The various terms considered are:

$$
\begin{aligned}
\text { Change in storage } & =\Delta S \\
\text { Inflow } & =P+Q i+G \\
\text { Outflow } & =Q o+E
\end{aligned}
$$

where

$\Delta S=$ change in volume of stored water,

$\mathbf{P}=$ volume of precipitation falling directly on the lake, in acre-feet,

$\mathrm{Q} \mathrm{i}=$ surface-water inflow, in acre-feet,

$\mathrm{Q} o=$ surface-water outflow, in acre-feet,

$\mathrm{G}=$ net ground-water flow, in acre-feet, and

$\mathrm{E}=$ volume of water evaporation from the lake, in acre-feet.
Therefore the hydrologic budget for Delavan Lake is written as

$$
\Delta S-P-Q i-G+Q o+E=0
$$

A water budget was calculated for the 1984 and 1985 water years using the data collected at the monitoring network previously described. Each term in the hydrologic budget was either measured or estimated. The budgets are shown in table 7. An estimate of runoff from the unmonitored area was made because the streamflow gaging stations do not monitor the total surface-water inflow to Delavan Lake. The larger of the unmonitored areas $\left(5.78 \mathrm{mi}^{2}\right)$-the shoreline drainage that drains directly into Delavan Lake-is an urban area and runoff was calculated using the runoff from Jackson Creek tributary, also an urban area. The runoff yield from Jackson Creek basin was used to calculate runoff for Delavan Lake tributary 1 basin because the basins' land use and topography are similar.

Measurement and interpretation errors are associated with each term in the hydrologic budget equation. To aid in evaluating these errors, the hydrologic budget can be written as:

$$
\Delta \mathrm{S}-\mathrm{P}-\mathrm{Qi}-\mathrm{G}+\mathrm{Qo}+\mathrm{E}-\mathrm{r}=\mathbf{0}
$$

where $r$ is a net residual term. Rewriting the hydrologic budget in terms of the net residual ( $r$ ) results in

$$
r=\Delta S-(P+Q i+G)+(Q o+E)
$$

The net residual associated with the 1984 water year was 5 percent of the total inflow to the lake and in the 1985 water year it was 9 percent. Errors associated with individual components may be greater than or less than these figures; the net residual term is simply a reflection of the overall integrity of the hydrologic budget.

The hydrologic budget shows that streamflow is the dominant component of the input budget; streamflow composes 59 percent and 54 percent, respectively, of the 1984 and 1985 water years' budgets. Precipitation is the next largest component ( 23 percent). Ground water is the smallest component; it composes 18 percent and 23 percent of the hydrologic budget for the 1984 and 1985 water years.

Streamflow also dominates the losses in the hydrologic budget; it comprises 78 percent for both water years. Evapotranspiration from the lake's surface makes up the remainder of the loss (22 percent).

\section{HYDRAULIC RESIDENCE TIME}

The hydraulic residence time for Delavan Lake is the time period required for the full volume of the lake, 44,806 acre-ft (acre-feet), to be replaced by inflowing waters. This is important for determining the expected response time of the lake to increased or reduced nutrient loadings. The 
smaller the lake volume and/or greater streamflow input, the shorter the residence time. Based on the hydrologic budget of total inflow to Delavan Lake of 20,288 acre-ft for the 1984 water year and 24,913 acre- $f$ for the 1985 water year, the calculated hydraulic residence times were 2.2 years and 1.80 years, respectively. However, these calculations were based on the assumption that the lake mixes completely, which is not the situation in Delavan Lake because of short circuiting (discussed in the section "Nutrient and Sediment Sources and Loading"). The true hydraulic residence time is likely greater than these calculated values. In comparison, Fowler Lake in Waukesha County in 1984, which has a small volume and a large streamflow input, had a hydrologic residence time of 7 days (P. E. Hughes, U.S. Geological Survey, written commun., 1986).

\section{WATER QUALITY \\ PHYSICAL AND CHEMICAL CHARACTERISTICS OF THE LAKE WATER COLUMN}

The characteristics of water allow for the formation of a stratified environment that controls the chemical and biological properties of lakes. Water temperature and

Table 6. Lake stage of Delavan Lake, 1984 and 1985 water years

[A dash indicates data unavailable; gage height in feet above datum of 922.92 feet]

Kean Values

$\begin{array}{llllllllllllllll}\text { DAY } & \text { OCT } & \text { HOV } & \text { DEC } & \text { JAN } & \text { FEB } & \text { MAR } & \text { APR } & \text { MAY } & \text { JWN } & \text { JUL } & \text { AUG } & & & \end{array}$

1984 Water Year (October 1983 - September 1984)

\begin{tabular}{|c|c|c|c|c|c|c|c|c|c|c|c|c|}
\hline 1 & -- & 4.31 & 4.73 & 4.24 & 4.22 & 4.41 & 4.38 & 4.72 & 5.24 & 5.04 & 4.97 & 4.86 \\
\hline 2 & 4.91 & 4.33 & 4.63 & 4.24 & 4.22 & 4.40 & 4.35 & 4.73 & 5.12 & 5.06 & 4.95 & 4.85 \\
\hline 3 & 4.92 & 4.46 & 4.50 & 4.25 & 4.21 & 4.40 & 4.35 & 4.73 & 5.06 & 5.05 & 4.96 & 4.84 \\
\hline 4 & 4.98 & 4.38 & 4.44 & 4.24 & 4.23 & 4.38 & 4.35 & 4.68 & 5.10 & 5.06 & 4.96 & 4.80 \\
\hline 5 & 4.96 & 4.35 & 4.46 & 4.24 & 4.22 & 4.36 & 4.33 & 4.67 & 5.10 & 5.05 & 4.96 & 4.80 \\
\hline 6 & -- & 4.85 & 4.46 & 4.23 & 4.23 & 4.37 & 4.30 & 4.66 & 5.10 & 5.05 & 4.94 & 4.78 \\
\hline 7 & 4.79 & 4.40 & 4.18 & 4.23 & --- & 4.37 & 4.32 & 4.66 & 5.16 & 5.04 & 4.95 & 4.78 \\
\hline 8 & --- & 4.38 & 3.80 & 4.22 & 4.23 & 4.37 & 4.32 & 4.66 & 5.16 & 5.02 & 4.99 & 4.76 \\
\hline 9 & -- & 4.38 & 3.78 & 4.24 & 4.23 & 4.36 & 4.32 & 4.64 & 5.17 & 4.98 & 4.98 & 4.80 \\
\hline 10 & 4.67 & 4.52 & 4.34 & 4.24 & 4.23 & 4.35 & 4.32 & 4.65 & 5.17 & 5.09 & 4.98 & 4.76 \\
\hline 11 & -- & 4.35 & 4.35 & 4.25 & 4.22 & 4.34 & 4.30 & 4.65 & 5.14 & 5.17 & 4.98 & 4.76 \\
\hline 12 & 4.65 & 4.42 & 4.38 & 4.23 & 4.23 & 4.34 & 4.30 & 4.65 & 5.10 & 5.18 & 4.96 & 4.76 \\
\hline 13 & 4.65 & 4.42 & 4.38 & 4.24 & 4.56 & 4.35 & 4.34 & 4.70 & 5.12 & 5.16 & 4.94 & 4.76 \\
\hline 14 & 4.65 & 4.46 & 4.40 & 4.24 & 4.78 & 4.35 & 4.39 & 4.70 & 5.12 & 5.16 & 4.92 & 4.76 \\
\hline 15 & 4.52 & 4.42 & 4.47 & 4.24 & 4.82 & 4.40 & 4.42 & 4.72 & 5.08 & 5.24 & 4.91 & 4.76 \\
\hline 16 & 4.48 & 4.48 & 4.46 & 4.23 & 4.82 & 4.45 & 4.46 & 4.72 & 5.08 & 5.14 & 4.91 & 4.75 \\
\hline 17 & 4.42 & 4.46 & 4.43 & 4.22 & 4.80 & 4.44 & 4.48 & 4.71 & 5.07 & 5.12 & 4.91 & 4.74 \\
\hline 18 & 4.40 & 4.48 & 4.42 & 4.21 & 4.80 & 4.50 & 4.52 & 4.71 & 5.20 & 5.08 & 4.90 & 4.68 \\
\hline 19 & 4.38 & 4.48 & 4.40 & 4.20 & 4.80 & 4.49 & 4.54 & 4.76 & 5.22 & 5.08 & 4.90 & 4.69 \\
\hline 20 & 4.36 & 4.50 & 4.39 & 4.19 & 4.78 & 4.53 & 4.56 & 4.78 & 5.20 & 5.07 & 4.88 & 4.69 \\
\hline 21 & 4.36 & 4.65 & 4.37 & --- & 4.75 & 4.53 & 4.56 & 4.79 & 5.14 & 5.07 & 4.88 & 4.66 \\
\hline 22 & 4.38 & 4.65 & 4.36 & 4.18 & 4.70 & 4.55 & 4.70 & 4.82 & 5.08 & 5.05 & 4.92 & 4.69 \\
\hline 23 & 4.38 & 4.75 & 4.36 & 4.16 & 4.68 & 4.53 & 4.71 & 4.86 & 5.10 & 5.05 & 4.90 & 4.70 \\
\hline 24 & 4.33 & 4.71 & 4.37 & 4.18 & 4.64 & 4.51 & 4.77 & 4.89 & 5.06 & 5.05 & 4.88 & 4.69 \\
\hline 25 & 4.27 & 4.77 & 4.38 & 4.19 & 4.60 & 4.51 & 4.77 & 4.80 & 5.00 & 5.03 & 4.88 & 4.89 \\
\hline 26 & 4.31 & 4.71 & 4.38 & 4.20 & 4.57 & 4.55 & 4.76 & 5.15 & 5.02 & 5.05 & 4.88 & 4.90 \\
\hline 27 & 4.29 & 4.73 & 4.38 & 4.18 & 4.57 & 4.53 & 4.73 & 5.22 & 5.02 & 5.04 & 4.85 & 4.90 \\
\hline 28 & 4.27 & 4.77 & 4.36 & 4.20 & 4.57 & 4.53 & 4.73 & 5.29 & 5.06 & 5.00 & 4.85 & 4.89 \\
\hline 29 & 4.27 & 4.69 & 4.25 & 4.20 & 4.57 & 4.48 & 4.68 & 5.42 & 5.06 & 5.00 & 4.86 & 4.88 \\
\hline 30 & 4.27 & 4.73 & 4.25 & 4.21 & -- & 4.48 & -- & 5.40 & 5.05 & -- & 4.84 & 4.88 \\
\hline 31 & 4.27 & --- & 4.25 & 4.21 & --- & 4.49 & --- & 5.30 & --- & 4.99 & 4.84 & $\cdots$ \\
\hline
\end{tabular}


dissolved oxygen are two properties that will be discussed in detail and $\mathrm{pH}$ will be discussed briefly. Water temperatures, dissolved oxygen, and $\mathrm{pH}$ profiles for the center site are shown in figures 10 and 11 . The other two sites at the opposite ends of the lake are not shown but the data are available at the U.S. Geological Survey office in Madison, Wis.

\section{Water Temperature}

Many climatic factors affect the water temperatures throughout Delavan Lake. Complete mixing of the lake is restricted by thermal stratification in the summer and by ice cover in the winter. Thermal stratification of lake water is a result of differential heating, water-temperature density, and wind-driven mixing. Water is unique among liquids because it reaches its maximum density (weight per unit volume) at about $4^{\circ} \mathrm{C}$.

As summer begins, the lake surface absorbs the sun's energy and the upper layer of water is heated. Wind action and, to some extent, internal heat transfer transmit this energy to underlying water. A density "barrier" begins to form between the warmer surface water and the lower, heavier, colder water. This barrier is marked by a sharp temperature

Table 6. Lake stage of Delavan Lake, 1984 and 1985 water years-Continued

[a dash indicates data unavailable; gage height in feet above datum of 922.92 feet]

Mean Values

$\begin{array}{llllllllllllll}\text { DAY OCT } & \text { NOV } & \text { DEC } & \text { JAN } & \text { FEB } & \text { MAR } & \text { APR } & \text { MAY } & \text { JUN } & \text { JUL } & \text { AUG } & \text { SEP }\end{array}$

1985 Water Year (October 1984 - September 1985)

\begin{tabular}{|c|c|c|c|c|c|c|c|c|c|c|c|c|}
\hline 1 & 4.88 & 4.88 & -- & 4.78 & 4.18 & 5.10 & 5.14 & 4.55 & 4.85 & 4.88 & 5.03 & 5.04 \\
\hline 2 & 4.87 & 5.00 & -- & -- & 4.30 & 5.14 & 5.08 & 4.55 & 4.85 & 4.89 & 5.04 & 5.04 \\
\hline 3 & 4.87 & 5.00 & 4.42 & -- & 4.30 & 5.14 & 5.08 & -- & 4.85 & 4.88 & 5.04 & 5.04 \\
\hline 4 & 4.84 & 4.96 & 4.40 & -- & 4.20 & 5.18 & 5.06 & 4.55 & 4.83 & 4.88 & 5.02 & 5.04 \\
\hline 5 & 4.84 & 4.90 & 4.38 & 4.68 & 4.20 & 5.20 & 5.06 & 4.54 & 4.84 & 4.90 & 5.02 & 5.06 \\
\hline 6 & 4.85 & 4.86 & 4.32 & 4.68 & 4.20 & 5.20 & 5.02 & 4.55 & 4.84 & 4.91 & 5.02 & 5.07 \\
\hline 7 & 4.86 & 4.81 & 4.32 & 4.64 & 4.22 & 5.20 & 5.04 & 4.58 & 4.84 & 4.90 & 5.05 & 5.07 \\
\hline 8 & 4.97 & 4.74 & 4.32 & 4.60 & 4.22 & 5.22 & 5.04 & 4.59 & 4.82 & 4.90 & 5.05 & 5.08 \\
\hline 9 & 4.98 & 4.72 & 4.30 & 4.57 & 4.22 & 5.24 & 4.98 & 4.59 & 4.82 & 4.89 & 5.02 & 5.26 \\
\hline 10 & 4.97 & 4.82 & 4.27 & 4.55 & 4.22 & 5.24 & 4.95 & 4.58 & 4.80 & 4.87 & 5.05 & 5.22 \\
\hline 11 & 4.95 & 4.82 & 4.27 & 4.52 & 4.22 & 5.26 & 4.92 & 4.56 & 4.82 & 4.87 & 5.04 & 5.18 \\
\hline 12 & 4.96 & 4.84 & 4.31 & 4.52 & 4.22 & 5.26 & 4.90 & 4.58 & 4.80 & 4.88 & 5.00 & 5.10 \\
\hline 13 & 4.96 & 4.80 & 4.33 & 4.50 & 4.22 & 5.26 & 4.88 & 4.60 & 4.80 & 4.88 & 5.12 & 4.99 \\
\hline 14 & 4.96 & 4.77 & 4.38 & 4.48 & 4.25 & 5.24 & 4.86 & 4.62 & 4.79 & 5.16 & 5.10 & 4.98 \\
\hline 15 & 4.96 & 4.75 & 4.36 & 4.44 & 4.25 & 5.22 & 4.81 & 4.64 & 4.84 & 5.15 & 5.06 & 4.90 \\
\hline 16 & 4.95 & 4.74 & 4.40 & 4.44 & 4.25 & 5.22 & 4.80 & 4.66 & 4.88 & 5.14 & 5.06 & 4.96 \\
\hline 17 & 4.96 & 4.62 & 4.40 & 4.42 & 4.25 & 5.14 & 4.73 & 4.66 & 4.80 & 5.12 & 5.05 & 4.92 \\
\hline 18 & 4.96 & 4.58 & 4.42 & 4.40 & 4.25 & 5.10 & 4.68 & 4.67 & 4.82 & 5.10 & 5.06 & 4.92 \\
\hline 19 & 4.96 & 4.52 & 4.70 & 4.40 & 4.25 & 5.05 & 4.69 & 4.68 & 4.86 & 5.06 & $-\cdots$ & 4.90 \\
\hline 20 & 5.04 & 4.48 & 4.39 & 4.40 & 4.25 & 5.02 & 4.64 & 4.68 & 4.86 & 5.08 & 5.02 & 4.92 \\
\hline 21 & 5.05 & 4.46 & 4.44 & 4.40 & 4.25 & 5.03 & 4.62 & 4.68 & 4.90 & 5.08 & 4.99 & 4.92 \\
\hline 22 & 5.02 & 4.42 & 4.40 & 4.38 & 4.25 & 5.03 & 4.58 & 4.65 & 4.90 & 5.08 & 4.99 & 4.92 \\
\hline 23 & 4.96 & 4.40 & 4.38 & 4.38 & 4.44 & 5.05 & 4.57 & 4.66 & 4.94 & 5.06 & 4.97 & 4.96 \\
\hline 24 & 4.90 & 4.36 & 4.38 & 4.38 & 4.71 & 5.09 & 4.60 & 4.66 & 4.94 & 5.05 & 4.97 & 4.95 \\
\hline 25 & 4.85 & 4.35 & 4.36 & -- & 4.99 & 5.10 & 4.58 & 4.66 & 4.94 & 5.02 & 4.99 & 4.96 \\
\hline 26 & 4.80 & 4.32 & 4.36 & 4.24 & 5.06 & 5.12 & 4.58 & 4.68 & 4.96 & 5.03 & 5.02 & 4.94 \\
\hline 27 & 4.80 & 4.40 & 4.35 & 4.23 & 5.06 & 5.10 & 4.58 & 4.84 & 4.94 & 5.03 & 5.00 & 4.94 \\
\hline 28 & 4.80 & 4.45 & 4.35 & 4.23 & 5.07 & 5.13 & 4.56 & 4.85 & 4.93 & 5.04 & 4.99 & 4.92 \\
\hline 29 & 4.80 & 4.47 & 4.34 & 4.18 & - & 5.15 & 4.55 & 4.85 & 4.92 & 5.02 & 5.01 & 4.92 \\
\hline 30 & 4.78 & 4.45 & 4.34 & 4.18 & $\cdots$ & 5.20 & 4.55 & 4.85 & 4.92 & 5.02 & 5.06 & 4.92 \\
\hline 31 & 4.78 & $-\cdots$ & 4.68 & 4.18 & $\cdots$ & 5.14 & $\cdots$ & 4.86 & $\cdots$ & 5.02 & 5.04 & -- \\
\hline
\end{tabular}


gradient known as the thermocline or metalimnion; it separates the warmer, less dense, upper layer of water called the epilimnion, from the cooler, more dense, lower layer called the hypolimnion. Once stratification begins the temperature of the hypolimnetic water changes little throughout the summer stratification period.

Delavan Lake is only weakly, thermally, stratified throughout the summer stratification period (fig. 10). This thermocline is not a barrier to fish migration but it inhibits the exchange of water between the two layers and has a great impact on both the chemical and biological activity in the lake. The development of the thermocline begins in early summer, reaches its maximum in late summer, and disappears in the fall (fig. 10). This stratification period lasts until the fall, when air temperatures cool the surface water and wind action results in the erosion of the thermocline.

As water cools, it becomes more dense, sinking and displacing the warmer water below. The colder water sinks and mixes because of wind action until the entire column of water is a uniform temperature. This lake season, which follows summer stratification, is known as fall turnover. When the water temperature drops below $4^{\circ} \mathrm{C}$, the water again becomes less dense and "floats" near the surface. Eventually the surface of the water is cooled until at $0^{\circ} \mathrm{C}$ ice forms and covers the surface of the lake, isolating the lake's liquid water from the atmosphere for 3 to 4 months. During the study period, ice cover existed from December 19, 1983, through April 4, 1984, and from January 4 to March 27, 1985.

Winter stratification occurs as the colder, less dense water and ice remain at the surface, again separated from the relatively warmer, more dense water near the bottom of the lake. Spring brings a reversal to the process. As the ice thaws and the upper layer of water warms, it becomes denser and begins to approach the temperature of the warmer, deeper water until the entire water column reaches the same temperature. This lake season, which follows winter stratification, is referred to as spring turnover and usually

Table 7. Hydrologic budget for Delavan Lake, 1984 and 1985 water years

\begin{tabular}{|c|c|c|c|c|}
\hline & \multicolumn{2}{|c|}{1984 water year } & \multicolumn{2}{|c|}{1985 water year } \\
\hline & $\begin{array}{l}\text { Total cubic feet } \\
\text { per second days }\end{array}$ & Acre-feet & $\begin{array}{l}\text { Total cubic feet } \\
\text { per second days }\end{array}$ & Acre-feet \\
\hline \multicolumn{5}{|l|}{ Inputs } \\
\hline Delavan Lake inlet & 4,215 & 8,360 & 4,628 & 9,180 \\
\hline \multicolumn{5}{|l|}{ Delavan Lake } \\
\hline tributary & 597 & 1,184 & 509 & 1,010 \\
\hline Delavan Lake tributary 1 & 190 & 378 & 191 & 380 \\
\hline \multicolumn{5}{|l|}{ Shoreline drainage around } \\
\hline Delavan Lake & $\underline{1,026}$ & $\underline{2,035}$ & $\underline{1,421}$ & $\underline{2,819}$ \\
\hline Total surface runoff & 6,028 & 11,957 & 6,749 & 13,389 \\
\hline \multicolumn{5}{|l|}{ Precipitation on } \\
\hline lake surface & 2,376 & 4,713 & 2,926 & 5,804 \\
\hline \multicolumn{5}{|l|}{ Net ground water } \\
\hline (estimated) & 1,824 & 3,618 & 2,884 & 5,720 \\
\hline Total inputs & 10,228 & 20,288 & 12,559 & 24,913 \\
\hline \multicolumn{5}{|l|}{$\underline{\text { Losses }}$} \\
\hline Delavan Lake outlet ${ }^{1}$ & 7,575 & 15,025 & 8,938 & 17,728 \\
\hline Evaporation & 2,067 & 4,100 & 2,483 & 4,925 \\
\hline Lake volume increase & 36 & 71 & 36 & 71 \\
\hline Total losses & 9,678 & 19,196 & 11,457 & 22,724 \\
\hline
\end{tabular}

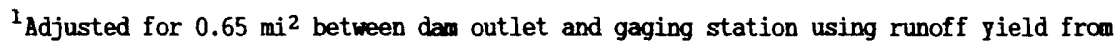
Jackson Creek. 

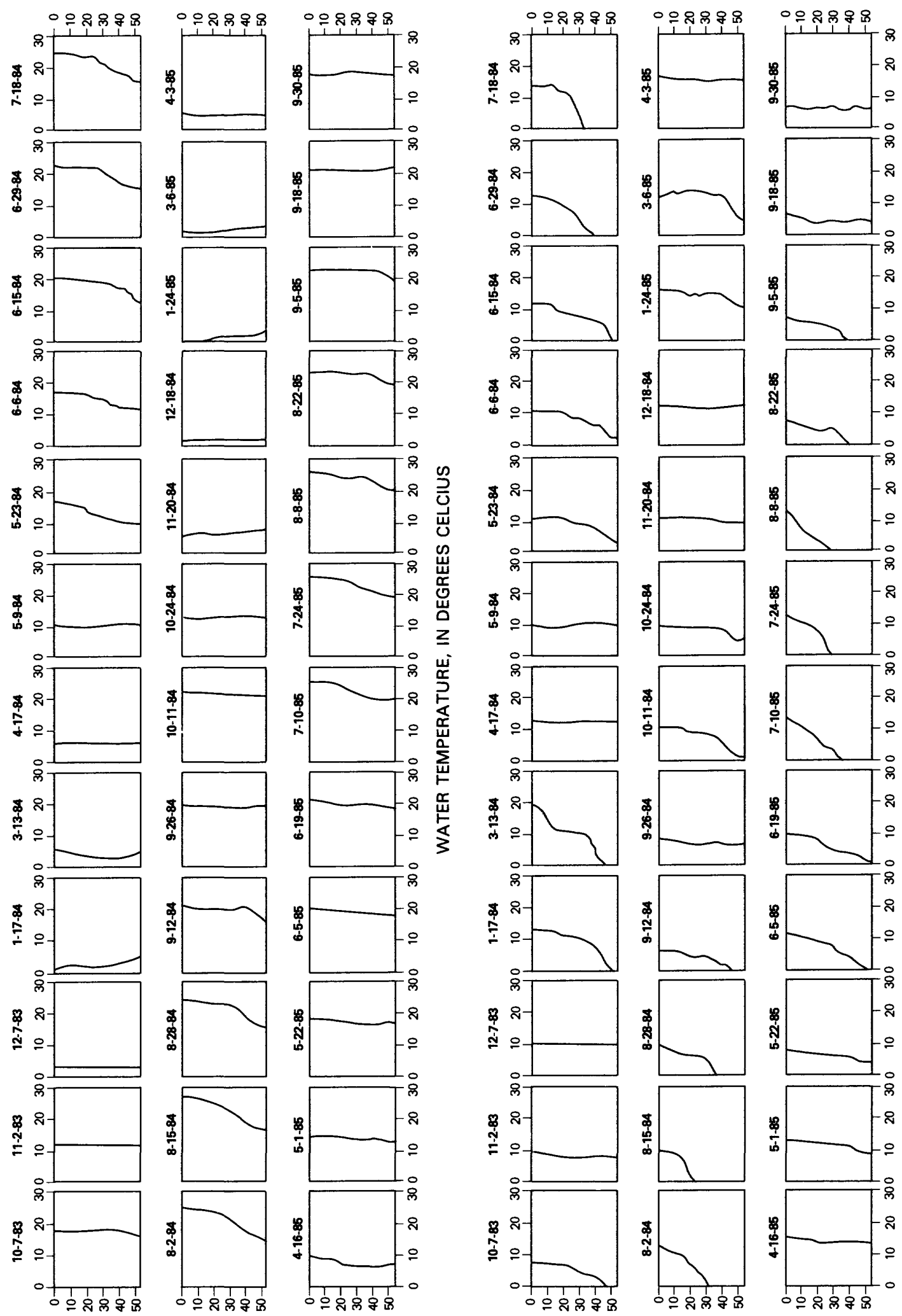

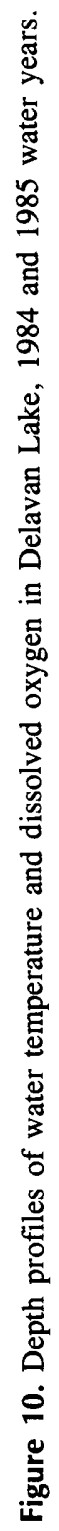
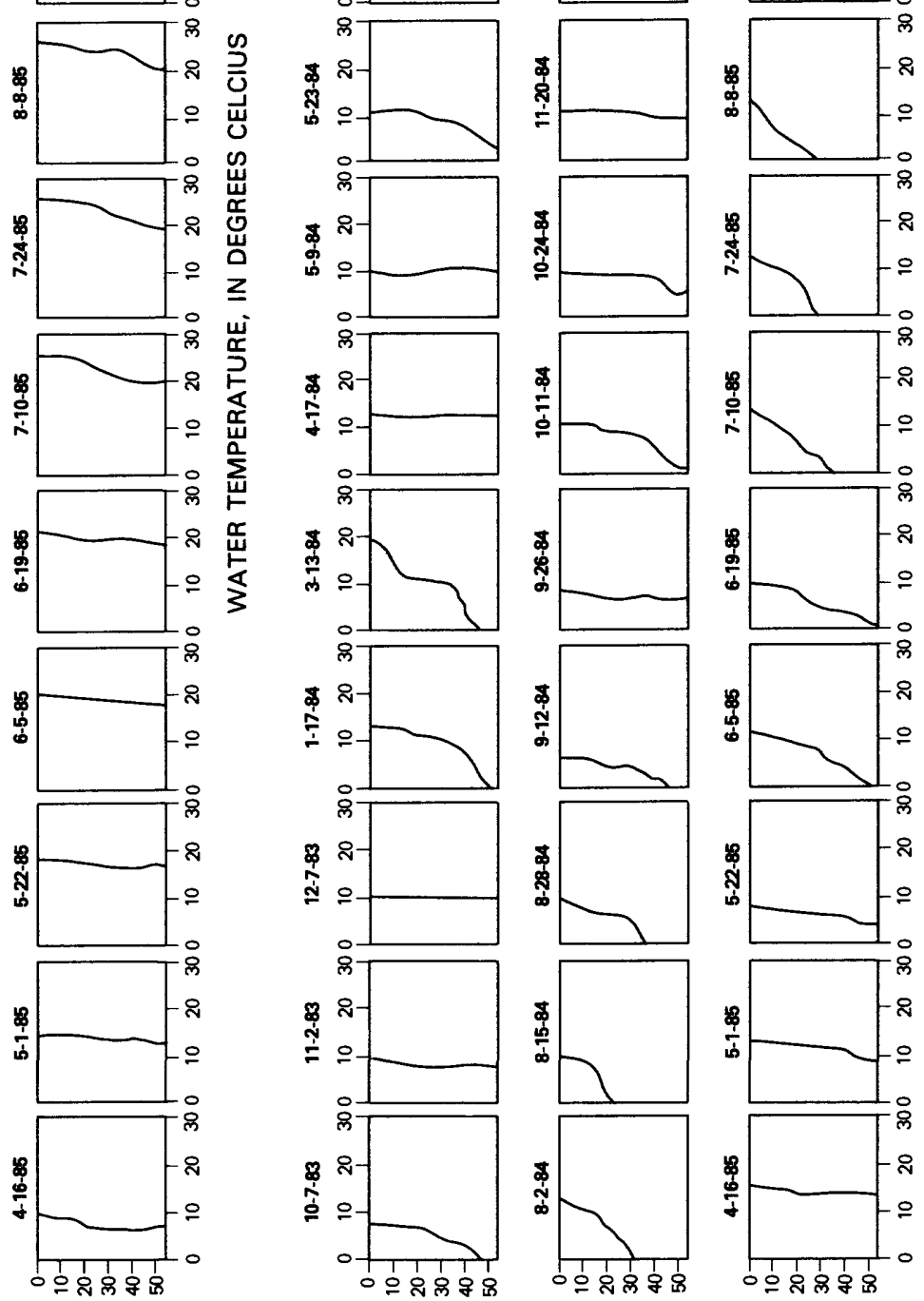

1 $\exists \exists \exists ~ N I ~ ' H \perp d \exists O ~ \exists X \forall \forall 7$ 
occurs within weeks after the ice melts. After this period, the water at the surface warms, again becoming less dense, and floats above the colder water. Wind and resulting waves carry some of the energy of the warmer, lighter water to lower depths, but only to a limited extent. Thus begins the formation of the thermocline and another summer thermal stratification.

\section{Dissolved Oxygen}

Dissolved-oxygen levels are one of the most critical factors affecting a lake ecosystem and they are essential to the metabolism of all aquatic organisms that require oxygen. Dissolved-oxygen depth profiles at the center site monitored in Delavan Lake are shown in figure 10. Anoxia (no dissolved oxygen) occurred in the bottom waters in the winter of 1984 (fig. 10). Oxygen was present throughout the entire water column during the winter of 1985. Dissolved-oxygen levels were adequate for the support of fish throughout the winter for depths less than $40 \mathrm{ft}$ (fig. 10).

In early summer, as the thermocline develops, the upper, warmer layer (epilimnion) cuts off the surface supply of dissolved oxygen to the lower, colder layer (hypolimnion). The hypolimnion thus becomes isolated from the atmosphere. Large populations of planktonic algae are produced because the waters of Delavan Lake are nutrient-rich. These organisms die, fall to the bottom of the lake, and decompose. A large oxygen demand from this decaying material depletes the oxygen content of the water beginning at the lake bottom. The oxygen depletion then progresses upward and, because Delavan Lake is only weakly stratified, migrates through the metalimnion to the top of the thermocline by mid-summer.

Anoxia during summer stratification was first noted in 1984 on June 15 . The zone reached a maximum by August 15 when depths greater than $23 \mathrm{ft}$ were devoid of oxygen. Anoxia was last noted on September 12. Fall turnover was noted on September 26 and oxygen was circulated throughout the entire lake. Anoxia was estimated to have lasted 102 days, from June 10 to September 20.

Summer anoxia was first noted in 1985 on July 10, reached a maximum zone from July 24 to August 8 when depths greater than $27 \mathrm{ft}$ were anoxic, and was last noted on September 5 . Fall turnover was noted on September 18. Anoxia was estimated to have lasted 81 days, from June 25 to September 14.

These anoxic conditions are typical of eutrophic lakes and anoxia, in varying degrees, is common in many of the eutrophic lakes in southeastern Wisconsin. However, when oxygen does disappear from the bottom water, oxygenreducing processes can cause phosphorus (if in large enough quantities in the lake sediments) to be released from the bottom sediments.

Delavan Lake has been treated with copper sulfate to kill algae and it is important to realize the ramifications of this treatment. Dissolved oxygen levels in lakes have been shown to be severely depressed after copper sulfate applica- tion (Hanson, 1981; Whitaker and others, 1978). A copper sulfate treatment killed a large quantity of algae in Budd Lake on June 29, 1978. The decomposition of these algal cells utilized large quantities of oxygen during the breakdown process. Dissolved-oxygen concentrations at the top of the lake dropped from $15 \mathrm{mg} / \mathrm{L}$ (milligrams per liter) to less than $4 \mathrm{mg} / \mathrm{L}$ during a 4-day period.

No effort was made during the study of Delavan Lake to continuously monitor the effects of declining oxygen concentrations due to the oxygen demand from decomposing algal cells killed by the chelated copper application. Chelated copper was applied to Delavan Lake 14 times from June through September during 1984; it was applied 14 times from June through August during 1985 (K. L. MacKinnon, DLSD, written commun., 1985). The cumulative copper chelate applications during 1984 amounted to 915 gal (gallon); 508 gal were applied during 1985.

\section{pH}

The photosynthetic and respiration processes of planktonic (free-floating) algae can have a significant effect on the $\mathrm{pH}$ of waters. These plants give off oxygen and consume carbon dioxide as they photosynthesize during daytime; they consume oxygen and give off carbon dioxide when they respire at night. When carbon-dioxide concentrations decrease, $\mathrm{pH}$ increases; when carbon-dioxide concentrations increase, $\mathrm{pH}$ decreases.

The large phytoplankton population in Delavan Lake uses much of the available carbon dioxide as they photosynthesize during the daytime and thereby cause the water near the lake surface to become highly alkaline, at times in excess of a $\mathrm{pH}$ of 9.0 (fig. 11). Natural water that has $\mathrm{pH}$ above 9.0 is unusual (Hem, 1985). However, because there are no living phytoplankton cells near the lake bottom, photosynthesis does not take place and a nearly neutral $\mathrm{pH}$ is maintained near the lake bottom during summer stratification.

\section{Nutrient and Chemical Analyses}

\section{SPRING TURNOVER}

The water mixes throughout the entire lake when spring turnover occurs. Concentrations of many constituents are most uniform at that time. Spring water-chemistry samples collected April 17, 1984, and April 3, 1985, are shown in table 8. Delavan Lake is a hard water, calcareous, eutrophic lake with alkalinity values averaging $181 \mathrm{mg} / \mathrm{L}$ as calcium carbonate (table 8). Total phosphorus concentrations are very large; the mean concentration was $0.143 \mathrm{mg} / \mathrm{L}$ as phosphorus on April 17, 1984 and $0.138 \mathrm{mg} / \mathrm{L}$ as phosphorus on April 3,1985 . These concentrations are seven times greater than $0.02 \mathrm{mg} / \mathrm{L}$, or the level where the eutrophic classification begins (Gerloff, G.C., University of Wisconsin, written commun., 1984; Wisconsin Department of Natural Resources, 1981 and 1983).

\section{PHOSPHORUS}

The general environmental requirements for the growth of green plants, including algae, are: light, water, essential 
minerals, suitable temperatures, oxygen, absence of toxic conditions, vitamins, ammino acids, and energy (Gerloff, G.C., University of Wisconsin, written commun., 1984). Phosphorus and nitrogen, two of the essential minerals, when in abundant supply can cause excessive algal blooms. Phosphorus is generally the nutrient that limits biological productivity (Wetzel, 1983). Nitrogen, however, often becomes the nutrient limiting plant growth as phosphorus loading to fresh waters increases. Excessive loading of these nutrients permits increased plant growth until other nutrients or light availability become the limiting growth factors.

Phosphorus concentrations have substantially increased in Delavan Lake since 1943 (Limnetics, Incorporated, 1969) (fig. 12). Much of this increase was likely due to high phosphorus loading from sewage effluent (see "Background"). A lake is classified eutrophic ${ }^{2}$ when surface phosphorus concentrations exceed $0.02 \mathrm{mg} / \mathrm{L}(20 \mu \mathrm{g} / \mathrm{L})$ of total phosphorus (Gerloff, G.C., University of Wisconsin, written commun., 1984; Wisconsin Department of Natural Resources, 1981 and 1983). Figure 13 shows that monthly average concentrations at the surface of the lake are well above this threshold.

Large fluctuations in the average in-lake total phosphorus concentrations occurred during the 2-year study period. A maximum of $0.184 \mathrm{mg} / \mathrm{L}$ was calculated on January 17 , 1984; a minimum of $0.054 \mathrm{mg} / \mathrm{L}$ was calculated on May 1 , 1985.

Phosphorus fluctuations at the bottom and top of Delavan Lake are shown in figures 13 and 14. Concentrations fluctuate significantly. The large increase in concentration at the bottom of the lake is primarily due to the large amounts of phosphorus that are released during anoxic periods from the sediments that are high in phosphorus. The chemical analyses of a sediment core collected August 1, 1984, at the center of the lake (54 ft depth) are shown in table 9 and reveal high phosphorus concentrations. According to a classification of the Great Lakes Harbor sediments (Environmental Protection Agency, 1977), phosphorus concentrations greater than $650 \mathrm{mg} / \mathrm{kg}$ (milligrams per kilogram) are indicative of "heavily polluted" water. Numerous laboratory studies have shown that phosphorus can be released from lake sediments when the overlying water is anoxic (Mortimer, 1941 and 1942; Theis and McCabe, 1978; Holdren and Armstrong, 1980).

Phosphorus concentrations above the sediments of Delavan Lake increased dramatically due to anoxic phosphorus release during the anoxic periods noted January 17 to March 13, 1984, June 15 to September 12, 1984, and July 10 to September 5, 1985. The dissolved-oxygen concentration $4 \mathrm{ft}$ above the lake bottom was $2.5 \mathrm{mg} / \mathrm{L}$ on March 6,1985 , although no anoxia was noted. It is likely that at the sediment-water interface the dissolved-oxygen concen-

${ }^{2}$ See discussion on eutrophic lakes in section "Carlson's TrophicState Index".
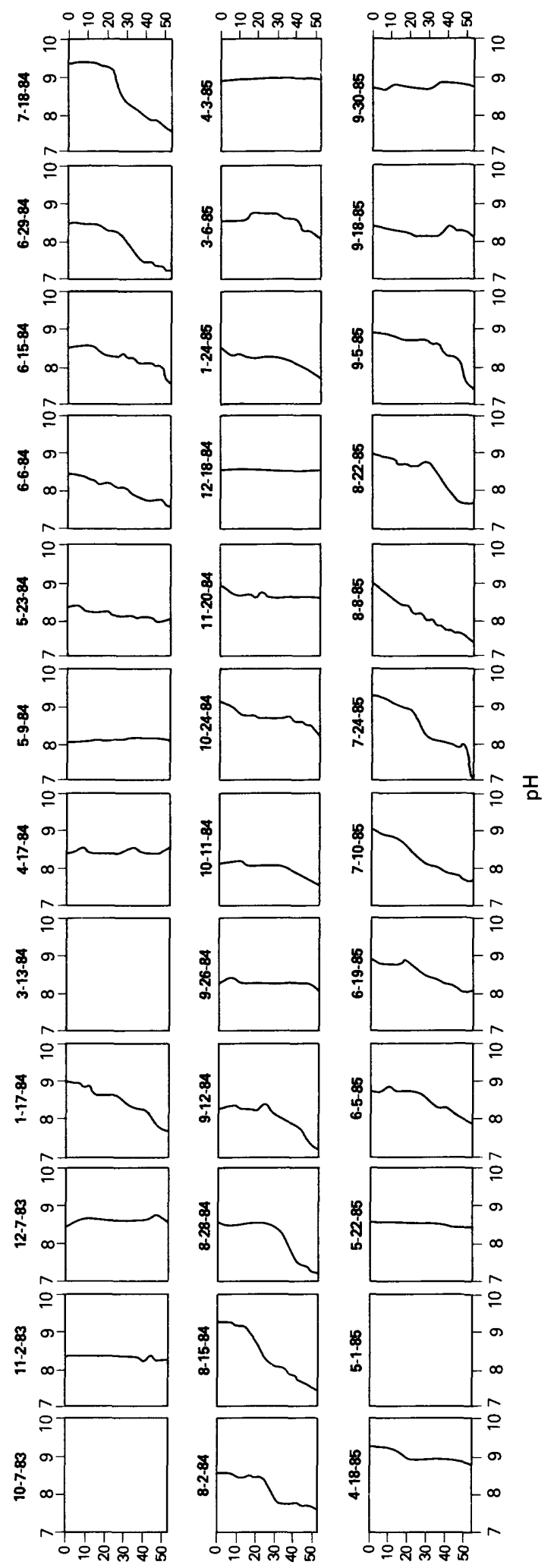

\section{I}
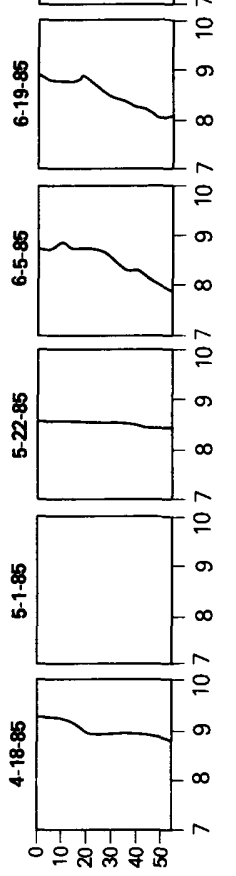

L $1 \exists \exists \unlhd \mathrm{NI} ` H \perp d \exists O \exists \times \forall 7$ 
Table 8. Spring water chemistry, April 17, 1984, and April 3, 1985, Delavan Lake

[Al] units in milligrams per liter unless otherwise indicated; $\mu \mathrm{g} / \mathrm{L}$, micrograms per liter; $\mu \mathrm{S} / \mathrm{cm}$, microsiemens per centimeter; a dash indicates data unavailable]

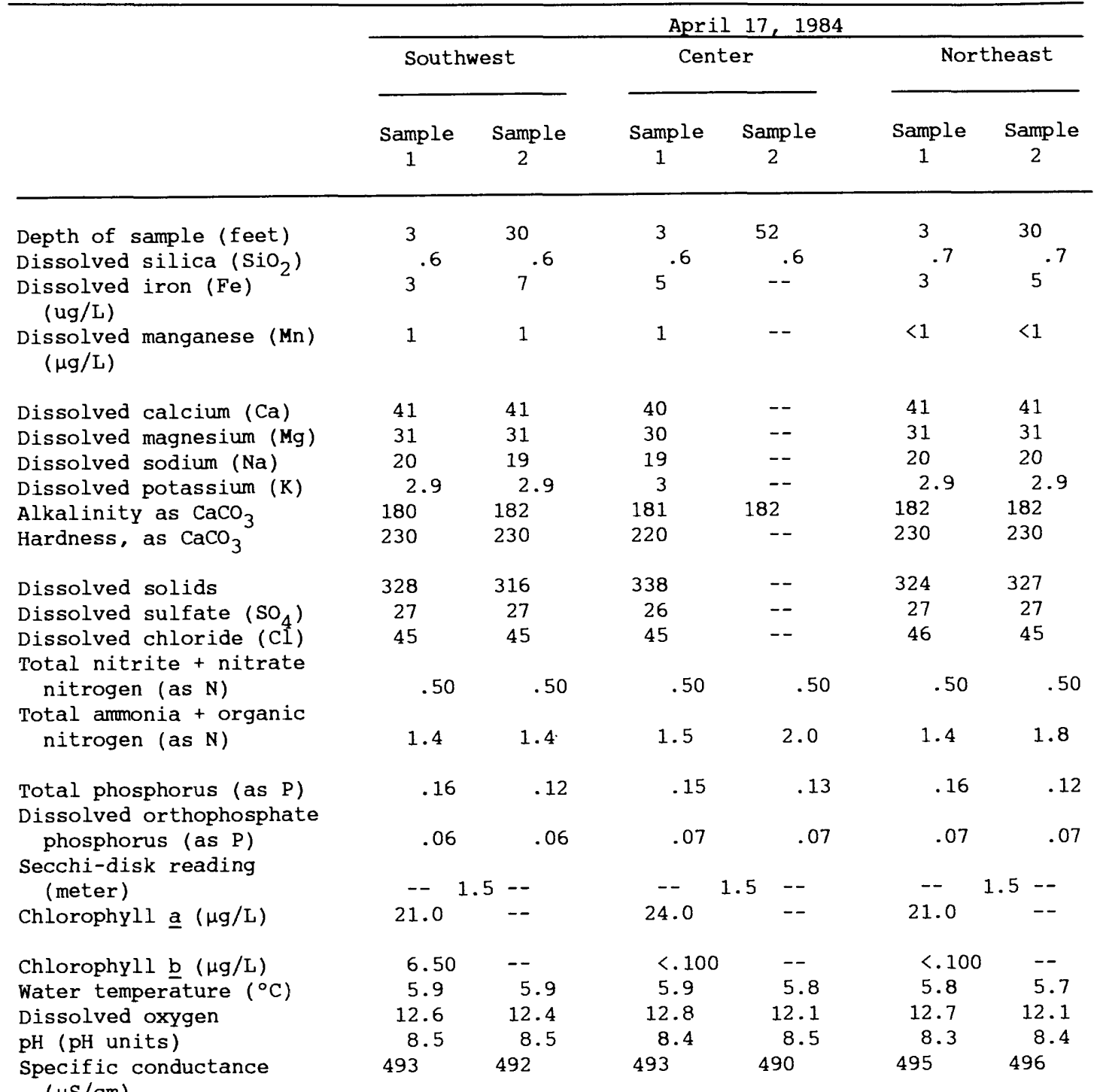

Table 9. Phosphorus, iron, manganese, arsenic, and moisture content of bed material at maximum depth

(54 feet) in Delavan Lake

[ $\mathrm{mg} / \mathrm{kg}$, milligrams per kilogram; $\mu \mathrm{g} / \mathrm{kg}$, micrograms per kilogram; $\mu \mathrm{g} / \mathrm{g}$, micrograms per gram]

\begin{tabular}{|c|c|c|c|c|c|c|}
\hline$\underset{\text { de }}{\text { Sedin }}$ & $\begin{array}{l}\text { ment core } \\
\text { epth } \\
\text { feet) }\end{array}$ & $\begin{array}{c}\text { Phosphorus } \\
\text { as } \mathrm{P} \\
(\mathrm{mg} / \mathrm{kg})\end{array}$ & $\begin{array}{c}\text { Iron } \\
(\mu \mathrm{g} / \mathrm{kg})\end{array}$ & $\begin{array}{c}\text { Manganese } \\
(\mu \mathrm{g} / \mathrm{kg})\end{array}$ & $\begin{array}{c}\text { Arsenic } \\
(\mu \mathrm{g} / \mathrm{gm})\end{array}$ & $\begin{array}{l}\text { Moisture } \\
\text { content } \\
\text { (percent) }\end{array}$ \\
\hline 0 & -0.33 & 1,200 & 4,600 & 490 & 3 & 84.5 \\
\hline 0.33 & -0.83 & & & & 6 & \\
\hline 0.83 & -1.33 & & & & 5 & \\
\hline 0.33 & -1.33 & 1,100 & 2,800 & 630 & & 83.1 \\
\hline 1.33 & -1.83 & & & & 4 & \\
\hline 1.33 & -2.33 & 1,100 & 2,300 & 490 & & 64.9 \\
\hline 1.83 & -2.33 & & & & 5 & \\
\hline 2.33 & -2.88 & 840 & 2,400 & 560 & 4 & 73.8 \\
\hline
\end{tabular}


Table 8. Spring water chemistry, April 17, 1984, and April 3, 1985, Delavan Lake-Continued

[All units in milligrams per liter unless otherwise indicated; $\mu \mathrm{g} / \mathrm{L}$, micrograms per liter; $\mu \mathrm{S} / \mathrm{cm}$, microsiemens per centimeter; a dash indicates data unavailable]

\begin{tabular}{|c|c|c|c|c|c|c|}
\hline & \multicolumn{6}{|c|}{ April 3, 1985} \\
\hline & \multicolumn{2}{|c|}{ Southwest } & \multicolumn{2}{|c|}{ Center } & \multicolumn{2}{|c|}{ Northeast } \\
\hline & $\begin{array}{l}\text { Sample } \\
1\end{array}$ & $\begin{array}{l}\text { Sample } \\
\quad 2\end{array}$ & $\begin{array}{l}\text { Sample } \\
1\end{array}$ & $\begin{array}{l}\text { Sample } \\
\quad 2\end{array}$ & $\begin{array}{l}\text { Sample } \\
1\end{array}$ & $\begin{array}{l}\text { Sample } \\
\quad 2\end{array}$ \\
\hline Depth of sample (ft) & 3 & 30 & 3 & 50 & 3 & 30 \\
\hline $\begin{array}{l}\text { Dissolved silica }\left(\mathrm{SiO}_{2}\right) \\
\text { Dissolved iron (Fe) }\end{array}$ & $<.1$ & $<.1$ & $<.1$ & $<.1$ & $<.1$ & $<.1$ \\
\hline$(\mu \mathrm{g} / \mathrm{L})$ & $<3$ & 3 & 3 & $<3$ & 5 & 7 \\
\hline $\begin{array}{l}\text { Dissolved manganese (Mn) } \\
(\mu \mathrm{g} / \mathrm{L})\end{array}$ & 1 & 2 & 2 & 2 & 2 & 1 \\
\hline Dissolved calcium (Ca) & 41 & 40 & 41 & 41 & 43 & 43 \\
\hline Dissolved magnesium ( $\mathrm{Mg})$ & 32 & 31 & 32 & 33 & 32 & 32 \\
\hline Dissolved sodium ( $\mathrm{Na}$ & 19 & 19 & 19 & 19 & 19 & 19 \\
\hline Dissolved potassium (K) & 2.7 & 2.5 & 2.6 & 2.7 & 2.6 & 2.6 \\
\hline Alkalinity as $\mathrm{CaCO}_{3}$ & 180 & 180 & 180 & 178 & 180 & 180 \\
\hline Hardness, as $\mathrm{CaCO}_{3}{ }^{\mathrm{J}}$ & 230 & 230 & 230 & 240 & 240 & 240 \\
\hline Dissolved solids & 316 & 328 & 320 & 315 & 320 & 328 \\
\hline Dissolved sulfate $\left(\mathrm{SO}_{4}\right)$ & 27 & 27 & 27 & 27 & 27 & 27 \\
\hline Dissolved chloride (Cl) & 45 & 45 & 46 & 45 & 47 & 46 \\
\hline $\begin{array}{l}\text { Total nitrite }+ \text { nitrate } \\
\text { nitrogen (as } \mathrm{N} \text { ) } \\
\text { Total ammonia }+ \text { organic }\end{array}$ & 1.1 & 1.1 & 1.1 & 1.1 & 1.2 & 1.2 \\
\hline nitrogen (as N) & .27 & .26 & .26 & .22 & .10 & .26 \\
\hline $\begin{array}{l}\text { Total phosphorus (as P) } \\
\text { Dissolved orthophosphate }\end{array}$ & .13 & .14 & .15 & .18 & .13 & .23 \\
\hline $\begin{array}{l}\text { phosphorus (as } \mathrm{P} \text { ) } \\
\text { Secchi-disk reading }\end{array}$ & .06 & .06 & .06 & .08 & .07 & $<.01$ \\
\hline (meter) & --1.5 & -- & -- & -- & 2.0 & -- \\
\hline Chlorophyll a $(\mu \mathrm{g} / \mathrm{L})$ & 8.10 & -- & 15.0 & -- & 17.0 & -- \\
\hline Chlorophyll $\underline{b}(\mu \mathrm{g} / \mathrm{L})$ & $<.10$ & -- & $<.100$ & -- & $<.100$ & -- \\
\hline Water temperature $\left({ }^{\circ} \mathrm{C}\right)$ & 4.0 & 4.4 & 4.4 & 4.3 & 4.6 & 4.4 \\
\hline Dissolved oxygen & 15.8 & 15.8 & 15.7 & 15.6 & 15.9 & 15.8 \\
\hline $\mathrm{pH}$ ( $\mathrm{pH}$ units) & 8.8 & 8.8 & 8.8 & 8.8 & 8.8 & 8.8 \\
\hline $\begin{array}{l}\text { Specific conductance } \\
(\mu \mathrm{S} / \mathrm{cm})\end{array}$ & 494 & 500 & 500 & 500 & 490 & 500 \\
\hline
\end{tabular}

tration was zero, which allowed the sediments to release phosphorus.

Phosphorus is released from the sediments in the dissolved form. The dissolved orthophosphate phosphorus and total phosphorus concentrations were nearly identical during the 1984 water year. ${ }^{3}$ Simple linear regressions of total phosphorus and dissolved orthophosphate phosphorus from June 6 to September 12, show slopes of the regression lines to be 6.4 and $6.7(\mu \mathrm{g} / \mathrm{L}) / \mathrm{d}$ (micrograms per liter per day), respectively, or nearly identical. It is unlikely that the dissolved orthophosphate phosphorus accumulation was the result of decomposing algal cells that contain phosphorus. Gachter and Mares (1985) found in a phosphorus-limiting lake, Lake Lucerne in Switzerland, that dead algal cells settling to the lake bottom accumulated dissolved reactive phosphorus by sorption rather than by releasing phosphorus.
The dissolved orthophosphate phosphorus and total phosphorus concentrations during the 1985 water year were similar except during the period July 10 to September 5 (fig. 14). The reason for this large deviation of total phosphorus from the dissolved orthophosphate phosphorus is that the total phosphorus concentration trend for this period probably reflects the phosphorus concentration in the settling dead algal cells (fig. 14). The upper graph of this illustration shows that the total phosphorus concentration trend duplicates the algal population trend except for a 2-week lag. Total phosphorus may not have followed the algal population trends in 1984 water year (fig. 14) because water circulation patterns in the lake differed from those in 1985 ,

${ }^{3}$ Dissolved orthophosphate phosphorus was greater than total phosphorus, on two occasions during 1984, either because of sample error, analytical error, or rounding error. 


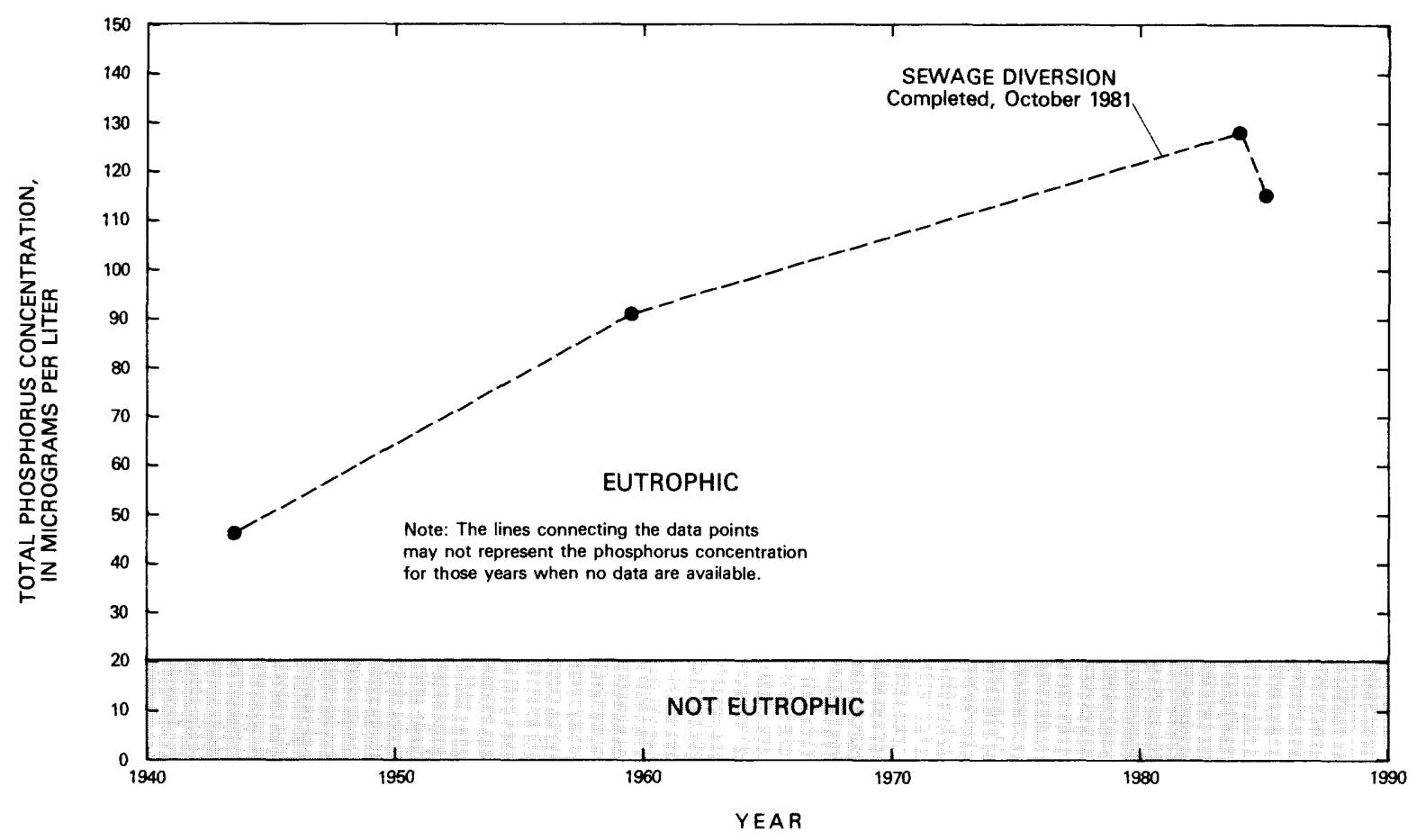

Figure 12. Trends in total phosphorus concentration in Delavan Lake, 12-month, average surface concentration, center site.

thereby the dead algal cells were deposited in a different part of the lake. A simple linear regression of the dissolved orthophosphate phosphorus from June 19 to August 22, 1985, shows that the slope of the regression line is $7.4(\mu \mathrm{g} / \mathrm{L}) / \mathrm{d}$. A regression of total phosphorus was not done because it reflected the phosphorus in the dead algal cells.

The phosphorus accumulation rates above the lake bottom in Delavan Lake are great and are almost twice those found in eutrophic Lake Mendota in Madison, Wis., by Sonzogni (1974). He found the accumulation rates for total phosphorus and dissolved reactive phosphorus ${ }^{4}$ were identical, but were different for 1971 and 1972, 3.9 and 3.1 $(\mu \mathrm{g} / \mathrm{L}) / \mathrm{d}$, respectively.

Phosphorus concentrations at the top of Delavan Lake also fluctuate considerably. They are generally greatest during fall turnover when large amounts of phosphorus, that are released from the bottom sediments during anoxia, are mixed throughout the lake. They are least in midsummer when algal cells use the phosphorus.

Algal cells use dissolved orthophosphate phosphorus to grow and they incorporate this phosphorus in their cell walls thereby becoming total phosphorus. Algal cells are shortlived organisms and when they die they settle to the lake bottom, carrying with them the phosphorus they utilized in their growth. Therefore, this growth and death of the algal cells in the top layer of water causes some of the change in the total phosphorus and dissolved orthophosphate concentra-

${ }^{4}$ Because the laboratory procedures for dissolved reactive phosphorus and dissolved orthophosphate phosphorus are the same, the analyses are considered comparable. tions. Also, because Delavan Lake is only weakly stratified, dissolved orthophosphate phosphorus that has been released from the bottom sediments during summer anoxic periods, migrates through the metalimnion into the epilimnion where it is almost immediately used by the algal cells. Stauffer (1974), in his study of Delavan Lake, found that cold fronts accompanied by high winds caused vertical migration of dissolved orthophosphate phosphorus from the hypolimnion into the epilimnion. Figure 14 shows that the total phosphorus concentrations increased $3 \mathrm{ft}$ below the water surface from June 8 to August 22, 1985. This was a period when external loading was very low (fig. 15, total phosphorus input) and was due to the phosphorus being released from the anoxic sediments and migrating from the hypolimnion to the epilimnion.

\section{NITROGEN}

Nitrogen, like phosphorus, when in abundant supply can cause excessive algal blooms although phosphorus commonly limits algal biomass in freshwater systems. The algal biomass in Delavan Lake at times appears to be nitrogen limited. Lakes with a total nitrogen to total phosphorus ratio greater than 15:1 are considered phosphorus limited; ratios between 10-15:1 are indicative of a transition situation; and ratio values less than 10:1 are generally indicative of nitrogen limitation (Lillie and Mason, 1983). The statistical summaries of the nitrogen-to-phosphorus ratios for the open-water periods from samples collected $3 \mathrm{ft}$ below the lake surface of Delavan Lake for the 1984 and 1985 water years are listed (p.28). 
Phosphorus concentrations 2 feet above lake bottom (center site) and average algal concentrations (SW and NE sites) 3 feet below lake surface Delavan Lake, 1984 Water Year

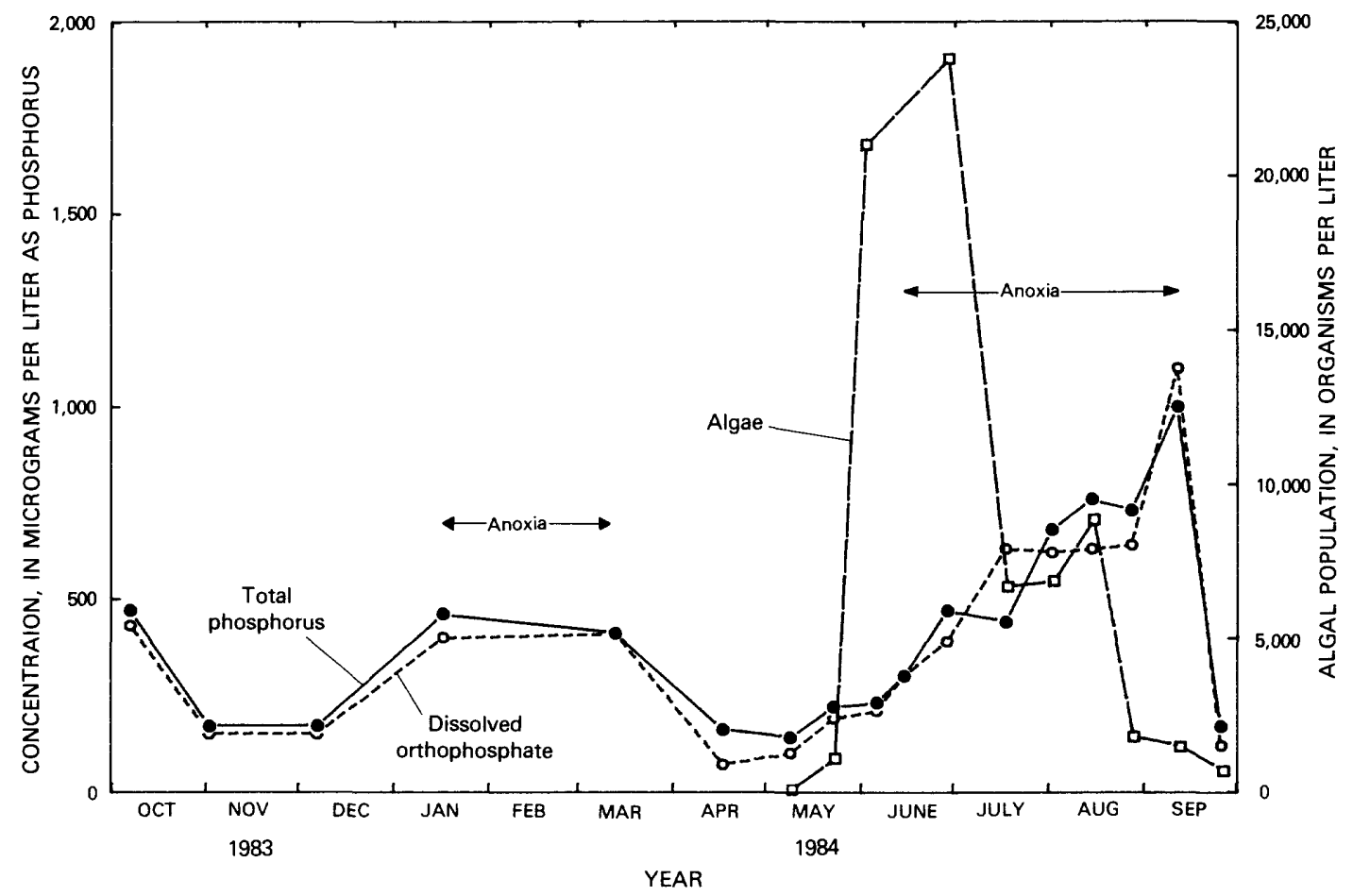

Phosphorus concentrations 3 feet below lake suface

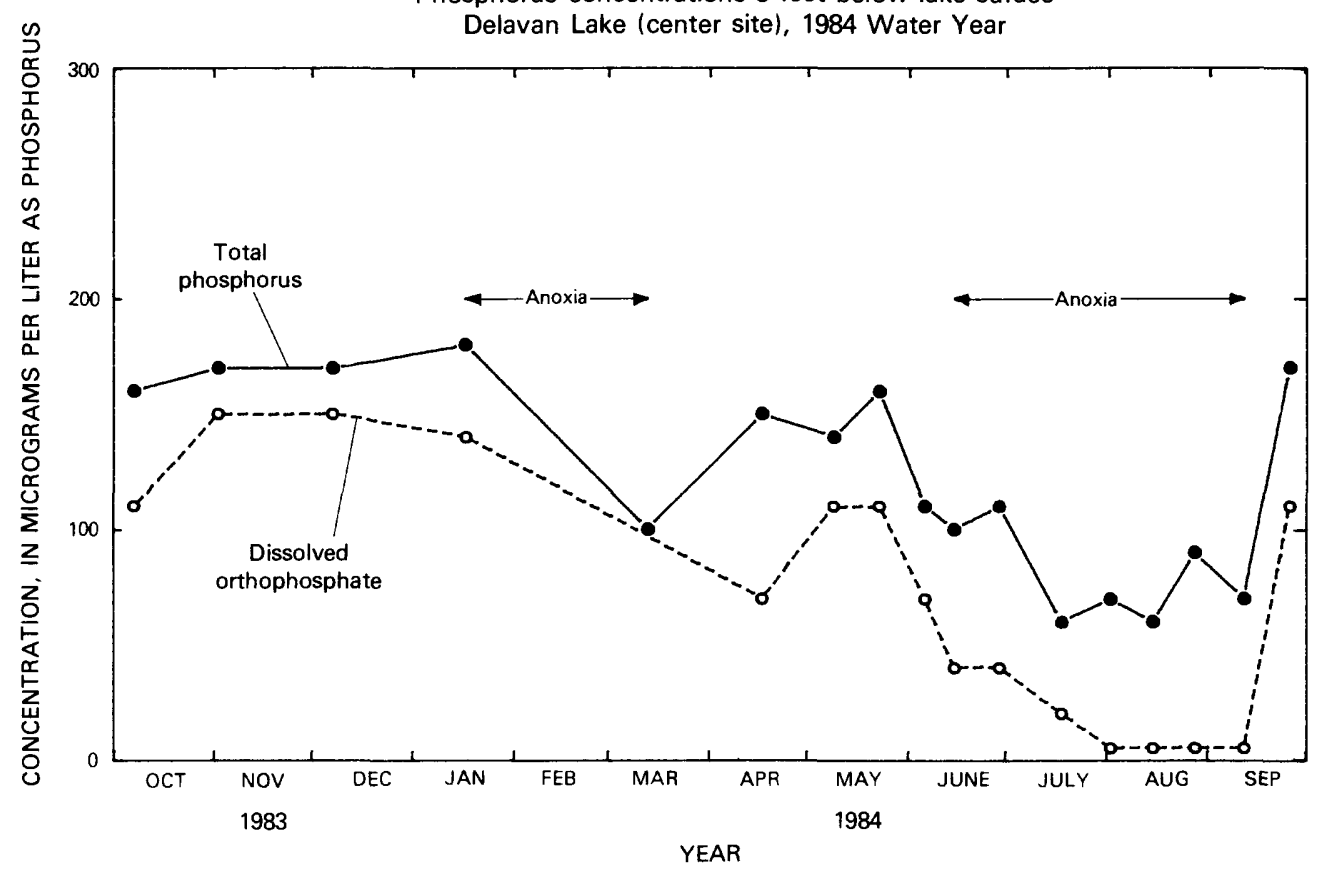

Figure 13. Phosphorus and algal concentrations in the bottom and top water layers of Delavan Lake, 1984 water year. 
Phosphorus concentrations 2 feet above lake bottom (center site) and average algal concentrations (SW and NE sites) 3 feet below lake surface Delavan Lake, 1985 Water Year

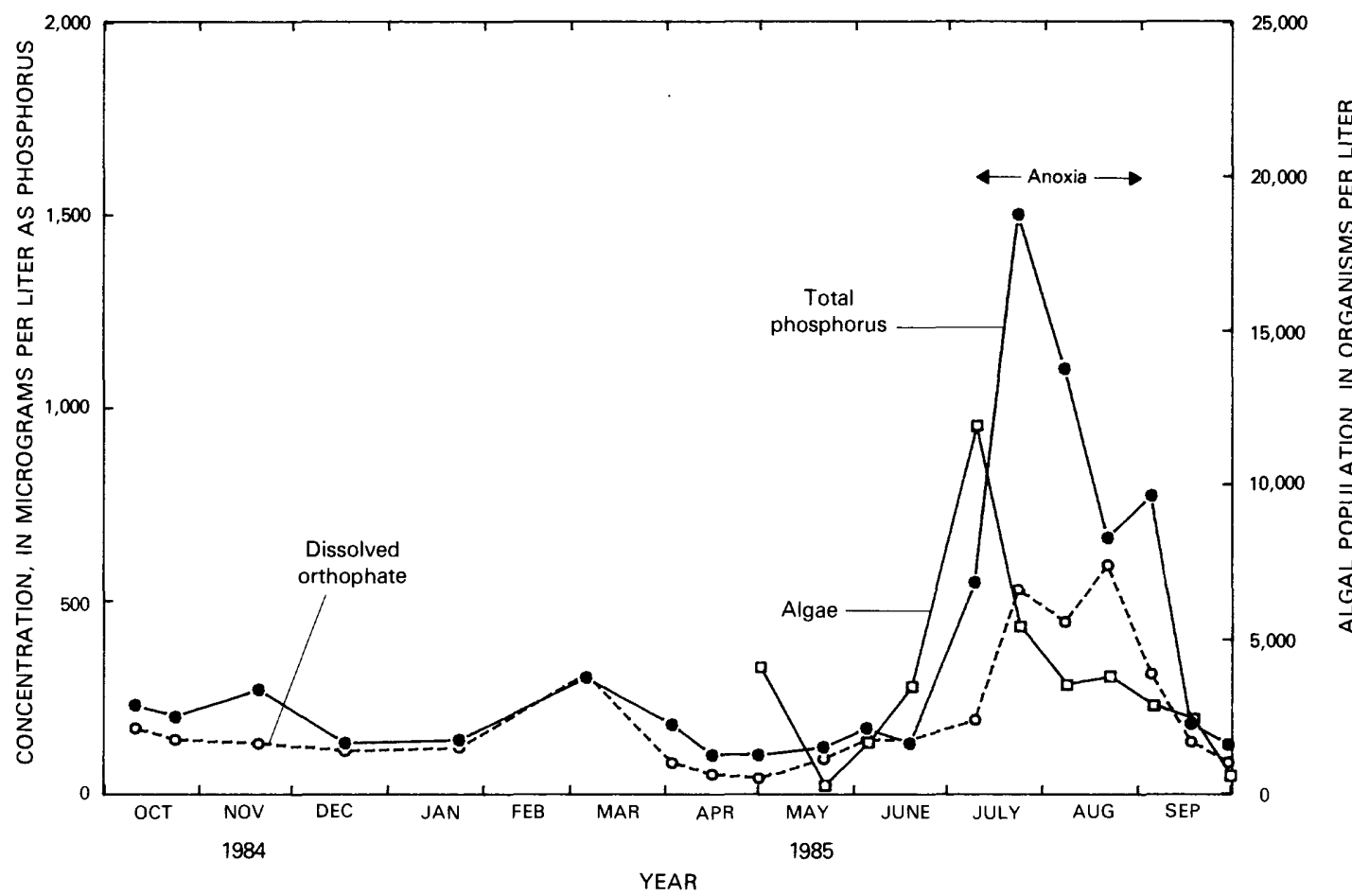

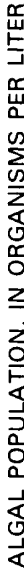

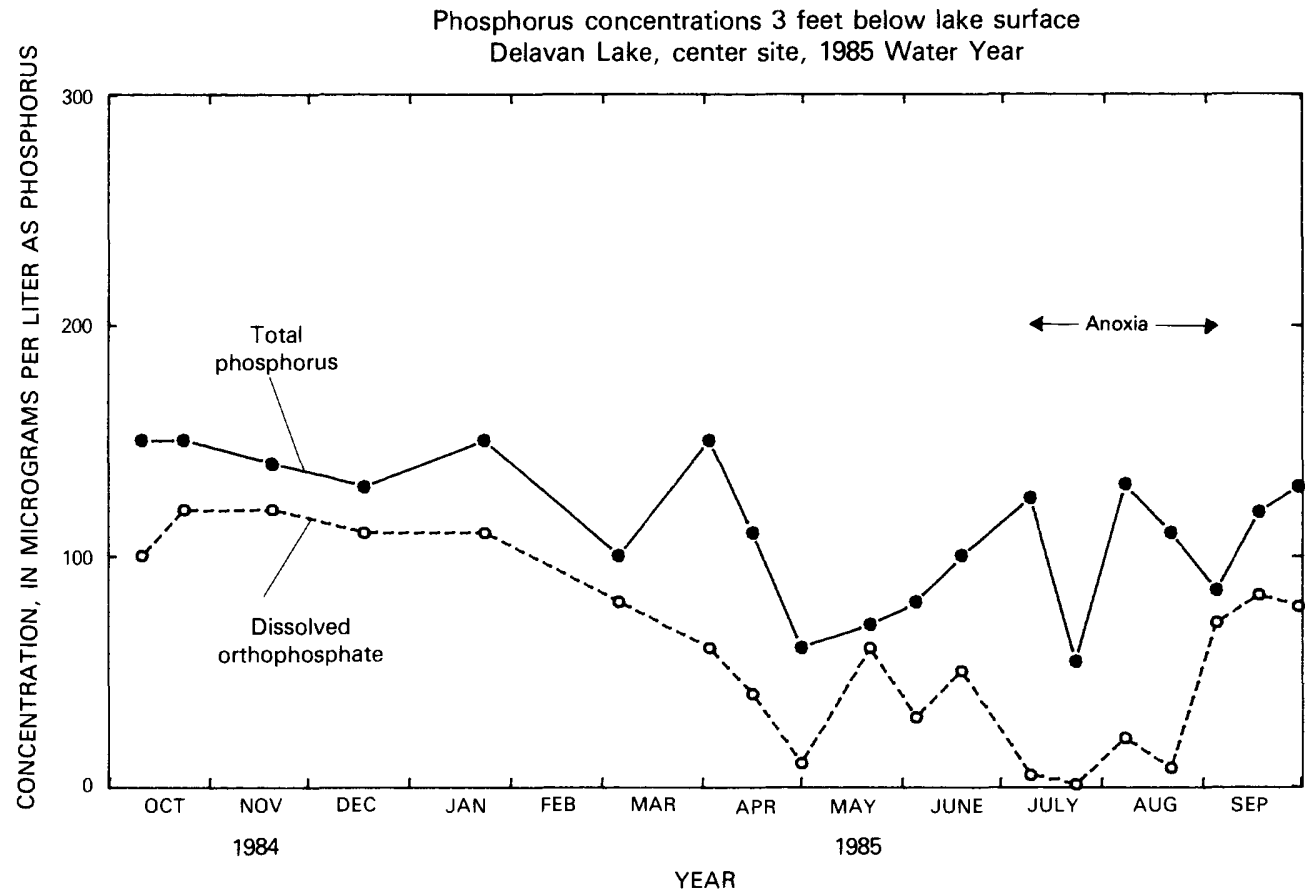

Figure 14. Phosphorus and algal concentrations in the bottom and top water layers of Delavan Lake, 1985 water year. 

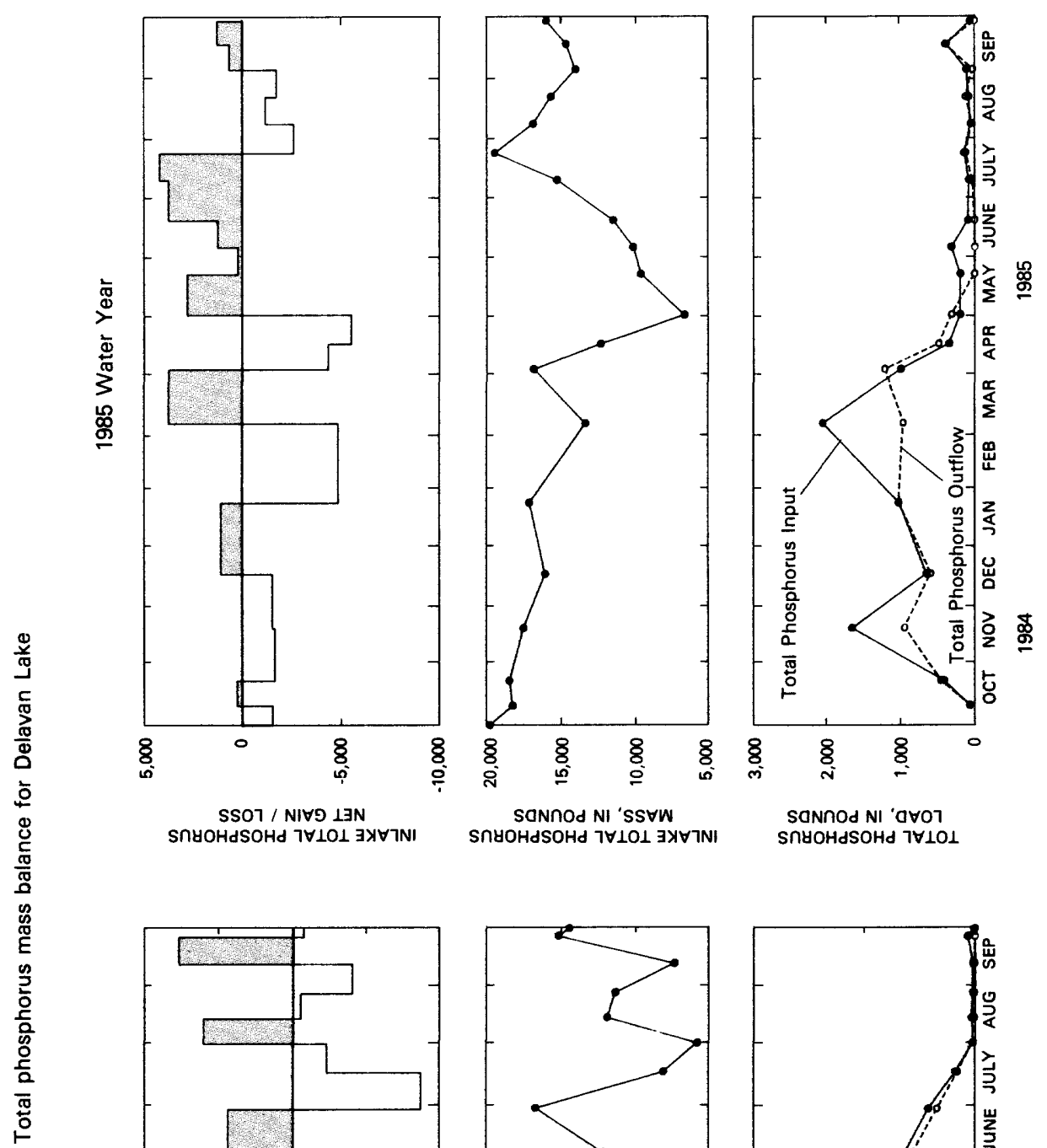

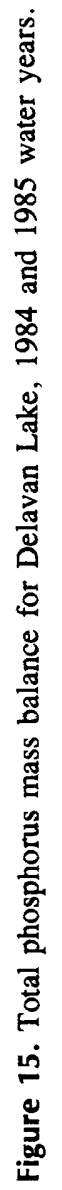
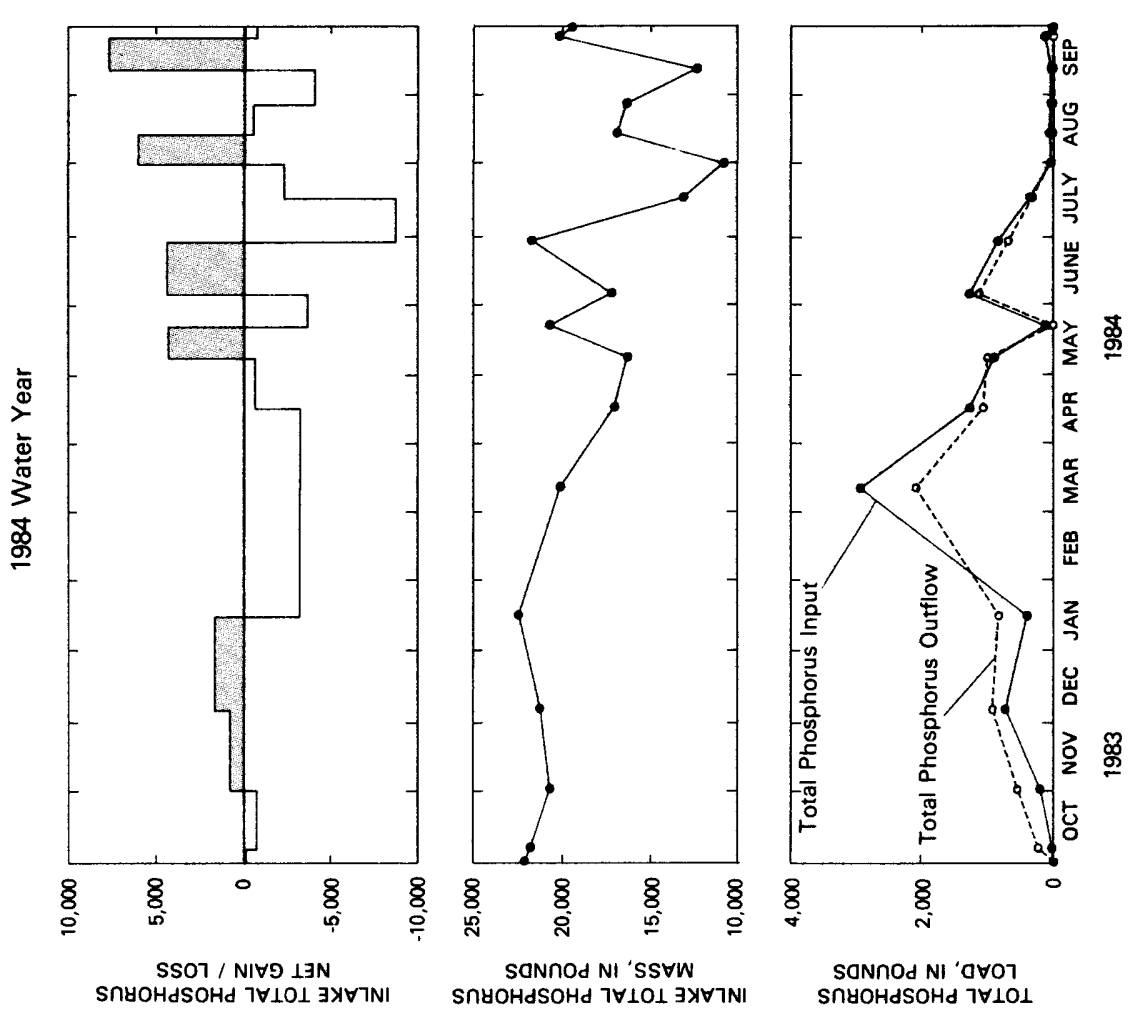


\begin{tabular}{lccc}
\hline & Southwestern end & Center & Northeastern end \\
\cline { 3 - 3 } Number & & 1984 Water Year & \\
Range & 14 & 14 & 14 \\
Median & $8.8-60$ & $9.4-28$ & $8.4-330$ \\
& 16 & 17 & 17 \\
Number & & 1985 Water Year & \\
Range & 15 & 17 & 16 \\
Median & $7.3-27$ & $8.6-32$ & $10-50$ \\
\hline
\end{tabular}

The spring turnover samples are included in the summaries above. The ratios for spring turnover samples were 12 at the two ends of the lake and 13 at the center site during the 1984 water year; the ratios were 14 at the center site, 15 at the southwest site, and 18 at the northeastern site during the 1985 water year.

Nitrogen limitation in Delavan Lake is hypothesized in the National Eutrophication 1972 Survey (Environmental Protection Agency, 1974). An algal assay of Selenastrum capricornutum during that survey showed that the species was nitrogen limited. Concentrations of nitrogen and phosphorus determined during EPA's study suggest nitrogen limitation because the nitrogen/phosphorus ratios were less than 10:1.

Nitrogen occurs in freshwater in various forms: "sources of nitrogen include: (a) precipitation falling directly onto the lake surface, (b) nitrogen fixation both in the water and the sediments, and (c) inputs from surface and groundwater drainage. Losses of nitrogen occur by (a) effluent outflow from the basin, (b) reduction of $\mathrm{NO}_{3}{ }^{-}$to $\mathrm{N}_{2}$ by bacterial denitrification with subsequent return of $\mathrm{N}_{2}$ to the atmosphere, and (c) permanent sedimentation loss of inorganic and organic nitrogen-containing compounds to the sediment" (Wetzel, 1983, p. 223).

Filamentous blue-green algae (except Oscillatoriaceae) also possess heterocysts (specialized cells within the algae) with which they obtain nitrogen from the atmosphere (nitrogen fixation).

Nitrogen undergoes various seasonal changes in the top and bottom layers of Delavan Lake (fig. 16). ${ }^{5}$ The changes in the top layers of the water are mostly influenced by changes in algal populations. The changes in the bottom layers of the water are largely caused when oxygen disappears (reduction) and reappears (oxidation).

In the top layer of the lake, where most of the algal population grows, ammonia nitrogen $\left(\mathrm{NH}_{4} \mathrm{~N}\right)$ and nitrite plus nitrate nitrogen $\left(\left(\mathrm{NO}_{2}+\mathrm{NO}_{3}\right)^{6}\right.$ are greatest during the winter when algal populations are lowest. They are least during midsummer when algal populations peak by utilizing the nitrate

\footnotetext{
s Nitrogen analyses were not determined in 1984 for all months.
}

${ }^{6}$ Most of the $\mathrm{NO}_{2}+\mathrm{NO}_{3} \mathrm{~N}$ is $\mathrm{NO}_{3} \mathrm{~N}$. "Nitrite $\left(\mathrm{NO}_{2}-\right)$ is readily oxidized and rarely accumulates except in the metalimnion, upper hypolimnion, or interstitial water of sediments of eutrophic lakes. Concentrations are usually very low (less than $100 \mu \mathrm{g} / \mathrm{L}$ ) unless organic pollution is high", (Wetzel, 1983, p. 253). Therefore, when nitrate nitrogen is mentioned it is implied that nitrite nitrogen is included. nitrogen and ammonia nitrogen to grow and then sink to the bottom. The data in figure 16 are consistent with this idea and suggest that during the spring and summer the ammonia nitrogen is used by the algae in preference to the nitrate nitrogen. This is normal because the energy necessary to assimilate ammonia nitrogen is least and increases for nitrate nitrogen. Nitrogen fixation by blue-green algae increases when ammonia nitrogen and nitrite plus nitrate nitrogen decrease in the summer (Wetzel, 1983).

The oxidation-reduction reaction at the bottom of the lake greatly changes the nitrate nitrogen and ammonia nitrogen concentrations. Most of the nitrogen is in the oxidized form (nitrate nitrogen) when oxygen is present. The nitrate nitrogen concentrations are greatest during spring and least during summer anoxia when the nitrate nitrogen undergoes denitrification.

"Denitrification by bacteria is the biochemical reduction of oxidized nitrogen anions, $\mathrm{NO}_{3}-\mathrm{N}$ and $\mathrm{NO}_{2}-\mathrm{N}$, with concomitant oxidation of organic matter' (Wetzel, 1983, p. 237). Nitrate nitrogen is thus converted to ammonia nitrogen under anoxic conditions. Ammonia nitrogen is least during the spring and fall but increases dramatically as anoxia occurs due to the decomposition of the decaying algal cells in the hypolimnion, denitrification, and the release of ammonia nitrogen from the sediments.

\section{SILICA}

Silica is important to the growth of diatomaceous algae. The major source of silica is from the degradation of aluminosilicate materials. Silica concentrations in the trophogenic zone (that upper layer where photosynthesis takes place) of eutrophic lakes are commonly near analytical undetectability (Wetzel, 1983). In lakes where silica concentrations are low, progressive long-term enrichment with phosphorus and nitrogen can lead to rapid biogenic reduction in silica levels so that diatoms cannot effectively compete and they are replaced by nonsiliceous phytoplankton (Kilham, 1971). Seasonal dissolved silica fluctuations at the top and bottom of Delavan Lake are shown in figure 17. The maximum silica concentration in the surface layer $3 \mathrm{ft}$ from the lake surface was $2.1 \mathrm{mg} / \mathrm{L}$; the minimum was at analytical undetectability $(<0.1 \mathrm{mg} / \mathrm{L})$. Diatoms use the silica in the surface layer of the lake and as they die they fall to the lake bottom. Decomposition of these diatoms increases the silica content of the bottom waters of Delavan Lake during summer and winter periods of stratification; maximum concentrations commonly reach 4 to $7 \mathrm{mg} / \mathrm{L}$. The large increases in dissolved silica concentrations during summer and winter anoxia also suggest that because silica sorbs to the iron hydroxides (as anoxia occurs) dissolved silica is released with the iron into the water column as the iron is released.

\section{Water Clarity}

The range of depths within which photosynthetic activity occurs depends largely on the transparency of the water. Sec- 
Nitrogen concentrations 2 feet above lake bottom

Delavan Lake, center site, 1985 Water Year

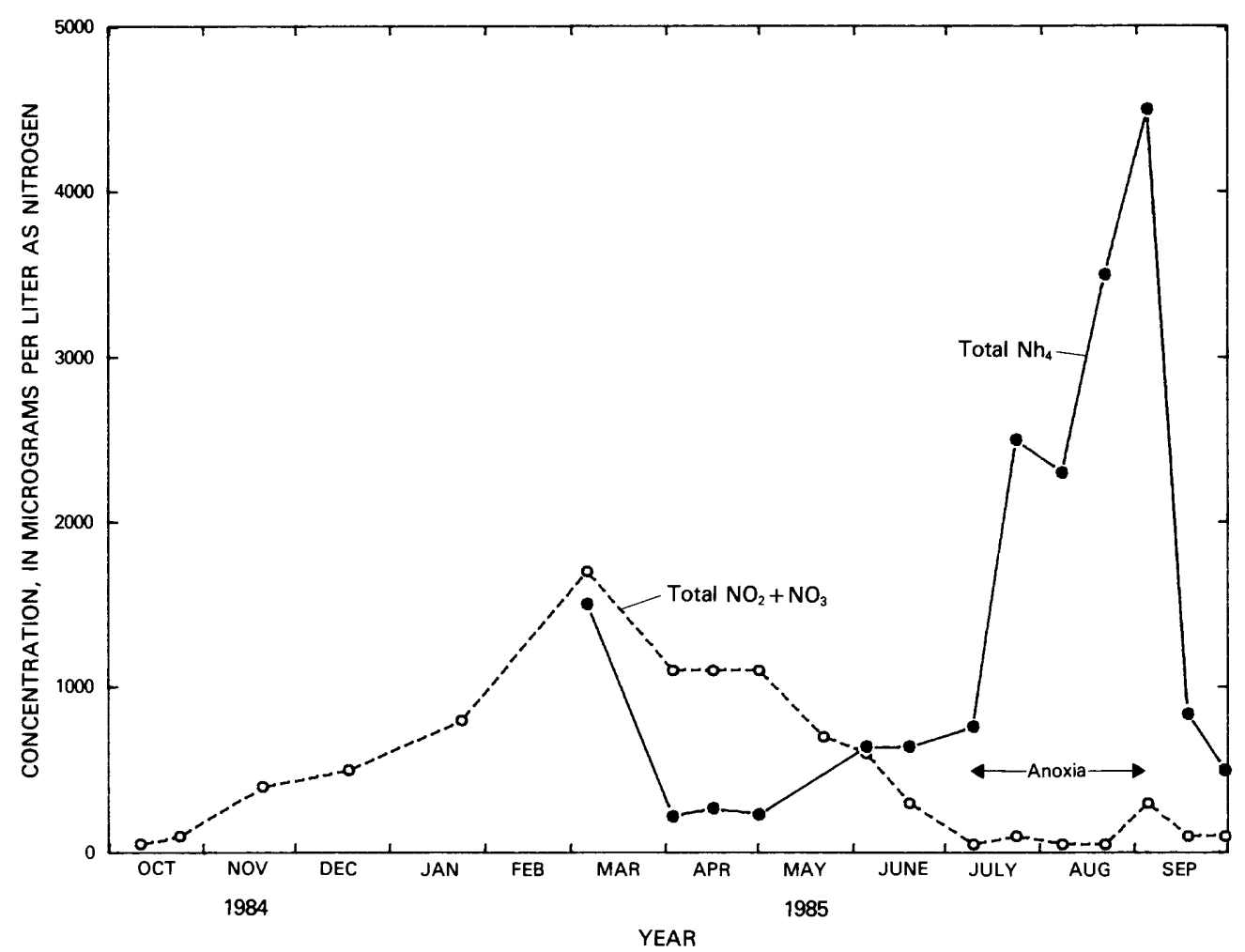

Nitrgen concentrations 3 feet below lake surface

Delavan Lake, center site, 1985 Water Year

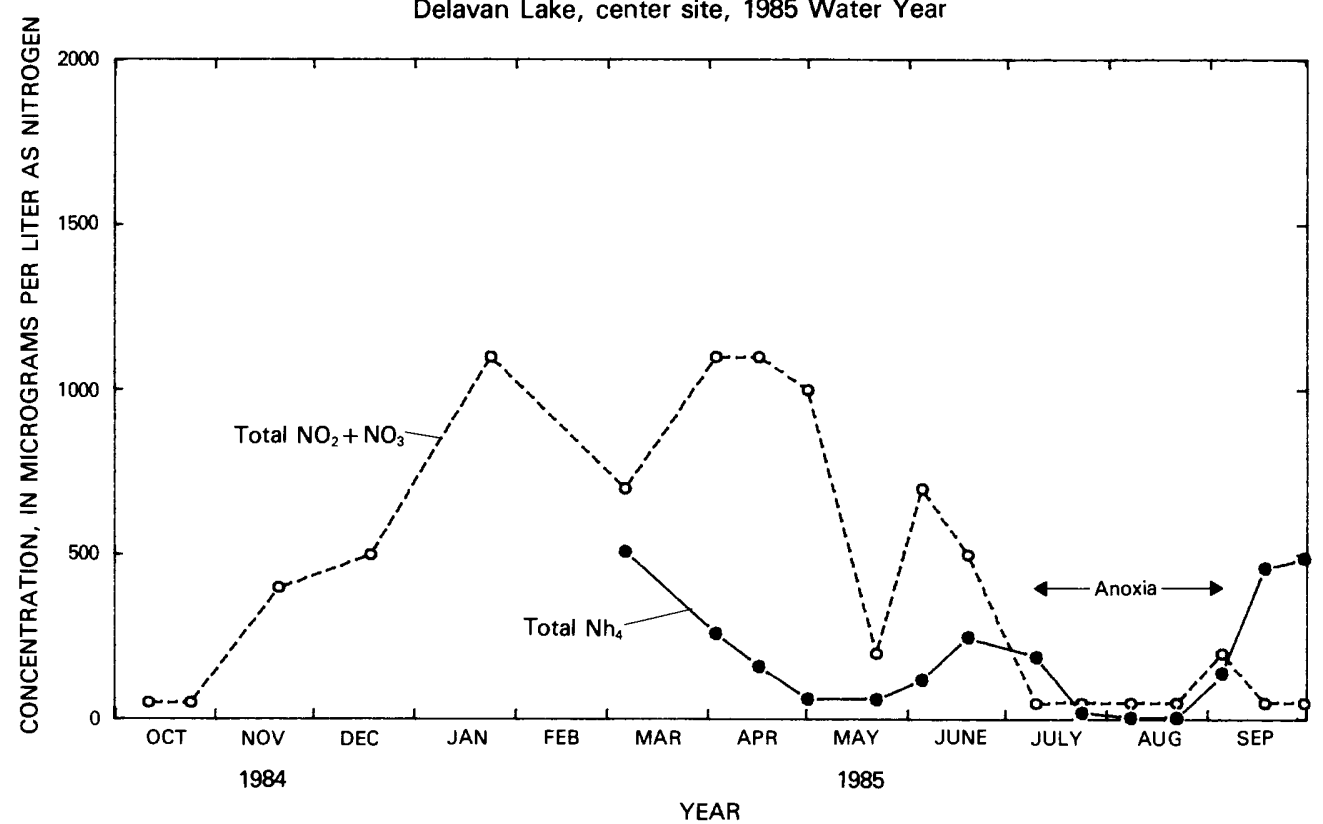

Figure 16. Nitrogen concentrations in the bottom and top water layers of Delavan Lake, 1985 water year. 
Silica concentrations 3 feet below lake surface Delavan Lake, center site, 1984 and 1985 Water Years

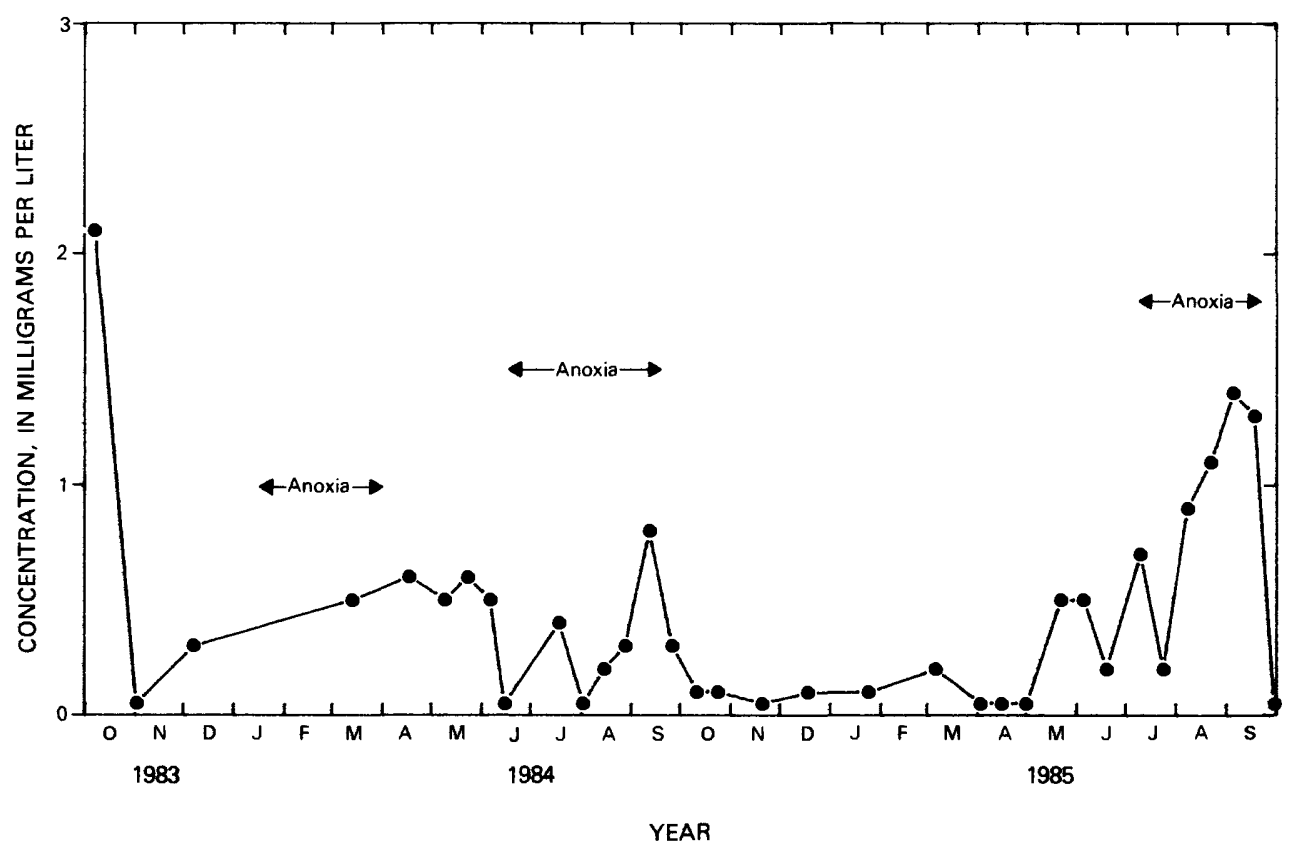

Silica concentrations 2 feet above lake bottom Delavan Lake, center site, 1984 and 1985 Water Years

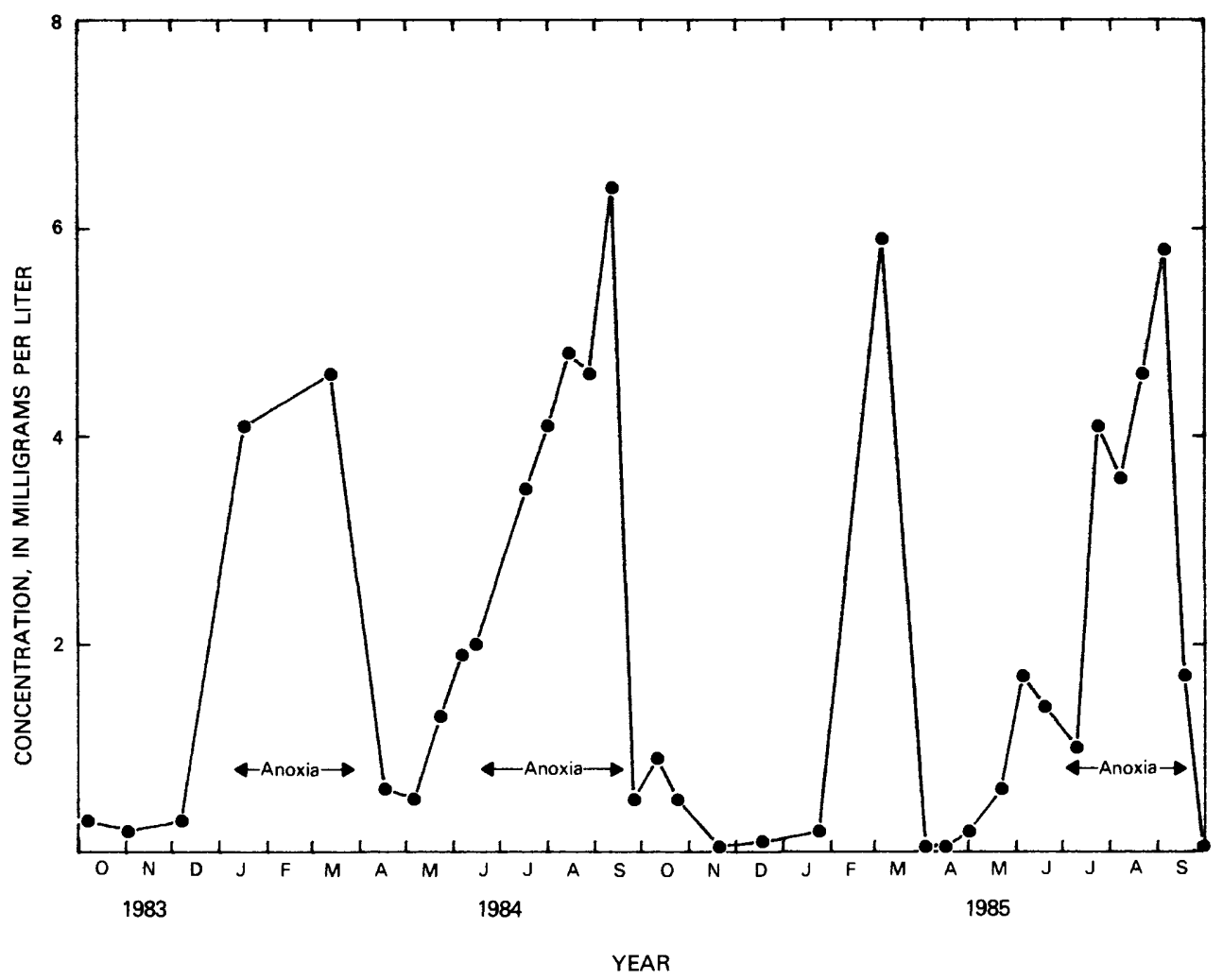

Figure 17. Dissolved silica concentrations, top and bottom water layers of Delavan Lake, 1984 and 1985 water years. 
chi disc measurements provide a measurement of this transparency or water clarity. A Secchi disc is an 8-in. black and white disc lowered to a depth at which it is no longer visible from the water surface. Factors that reduce water clarity are algae, zooplankton, water color, and suspended sediment. Algae is the most dominant factor in Delavan Lake, and therefore Secchi disc transparency is significantly correlated with the algal population. Secchi disc transparency is least during summer because algal populations are largest during this time. A minimum Secchi disc transparency of $1.6 \mathrm{ft}$ was measured July 10 and August 8,1985 . A maximum Secchi disc transparency of $21 \mathrm{ft}$ was measured January 24,1985 , during winter when algal populations are lowest. The Secchi disc transparency values are affected when the DLSD sprays chelated copper to kill algal populations; as the algal cells die and settle to the bottom the water clarity increases and Secchi transparencies are increased.

\section{Chlorophyll a}

Chlorophyll $a$ is the primary photosynthetic pigment of all oxygen-evolving photosynthetic organisms and is present in all algae (Wetzel, 1983). It is therefore an indicator of algal biomass. Chlorophyll $a$ concentrations are least during winter when algal populations are lowest and are greatest during summer when algal populations are highest. The chlorophyll $a$ concentrations at the three sites monitored in Delavan Lake are shown in the illustrations with Secchi disc transparency (fig. 18) to illustrate how the algal populations affect the Secchi disc transparency. As the chlorophyll $a$ concentrations increase, reflecting an increase in the algal population, the Secchi disc transparency decreases; as the chlorophyll $a$ concentrations decrease, the Secchi disc transparency increases. Chlorophyll $a$ concentrations reached a maximum of $87 \mu \mathrm{g} / \mathrm{L}$ on July 10,1985 , and a minimum of $0.1 \mu \mathrm{g} / \mathrm{L}$ on December 18, 1984, and March 6, 1985.

\section{Plankton}

ALGAE

Algae are small, generally microscopic plants that are found in all lakes and streams. They occur in a wide variety of forms, in single cells or colonies, and can be either attached (periphytic) or free floating (planktonic). Algae are primary producers that form the base of the aquatic food chain. They convert energy and nutrients into the compounds necessary to support life in the aquatic system through photosynthesis. Oxygen, which is vital to higher forms of life in a lake, is also produced in the photosynthetic process.

Blue-green algae (Cyanophyta) are not ordinarily used as food by zooplankton (microscopic animals) or fish populations and may become overabundant and out of balance with the organisms that feed on them. Population explosions (blooms) of blue-green algae can occur when nitrogenlimiting conditions occur (that is, nitrogen-phosphorus ratios are low), optimum sunlight and temperature conditions exist, and there is a lack of competition from other species.
Algal blooms may reach nuisance proportions in fertile or eutrophic lakes and cause surface scum or slime. Heavy concentrations of wind-blown algae may accumulate on shorelines, where they die and decompose, causing noxious odors and unsightly conditions. The decay process consumes oxygen; decay sometimes depletes available oxygen supplies and results in fish kills. Certain species of decomposing bluegreen algae release toxic materials into the water.

The algal succession in Delavan Lake proceeds as in other eutrophic, temperate, waters. A spring algal bloom occurs as light conditions improve after the ice melts; the bloom consists mostly of diatoms (Bacillariophyta) and cryptophytes (Croptophyta). Silica concentrations in the surface waters decrease as diatoms utilize the silica in their growth (fig. 17). As water temperatures increase, summer populations of green algae flourish until concentrations of ammonia nitrogen and nitrite plus nitrate nitrogen decrease. Blue-green algae have a competitive advantage over other species because they have heterocysts in their cell walls that enable them to utilize atmospheric nitrogen and proliferate when nitrogen levels are reduced to very low levels $(<0.10 \mathrm{mg} / \mathrm{L})$.

Total algal populations at the southwestern and northeastern ends of the lake are shown in figure 19. These populations are from a top 3-ft composite water sample of the lake. June 1984 had the largest summer algal populations of the 2 -year study period, averaging 22.4 million organisms per liter. This was almost twice as large as the maximum summer peak of 11.9 million organisms per liter during the 1985 water year. Blue-green algae (Cyanophyta) were the numerically dominant group during the 1984 water year, when algal populations were greatest in June, July, and August. They made up 98, 95, and 84 percent, respectively, of the total population (fig. 19). The most abundant species was Synechocystis sp. The cells of this algae are spherical and may be solitary or aggregated in colonies of a few cells (Smith, 1950).

Blue-green algae again numerically dominated the maximum algal bloom during the summer months of 1985 . However, the blue-green population, as a percentage of the total population, declined from the high percentages in 1984 to (monthly averages) 43 percent in June, 76 percent in July, and 71 percent in August. Synechocystis sp. declined from being the numerically dominant blue-green species in the summer months of 1984 to being codominant with Anabena circinalis in June 1985. In July 1985, Aphanizomenon flosaqua was the numerically dominant species and Synechocystis sp. ranked as the second largest population. Aphanizomenon flos-aqua was the sole numerically dominant species in August.

Anabena occurs in filaments either singly or in floccose colonies and free floating as in a delicate mucous stratum (Smith, 1950). Aphanizomenon are laterally joined to one another in small, macroscopic, free-floating, feathery, or scale-like colonies. Smith (1950) states " $A$. flos-aqua is widely distributed but rarely found in abundance"; on August 22, 1985, at the northeastern end of Delavan Lake, 

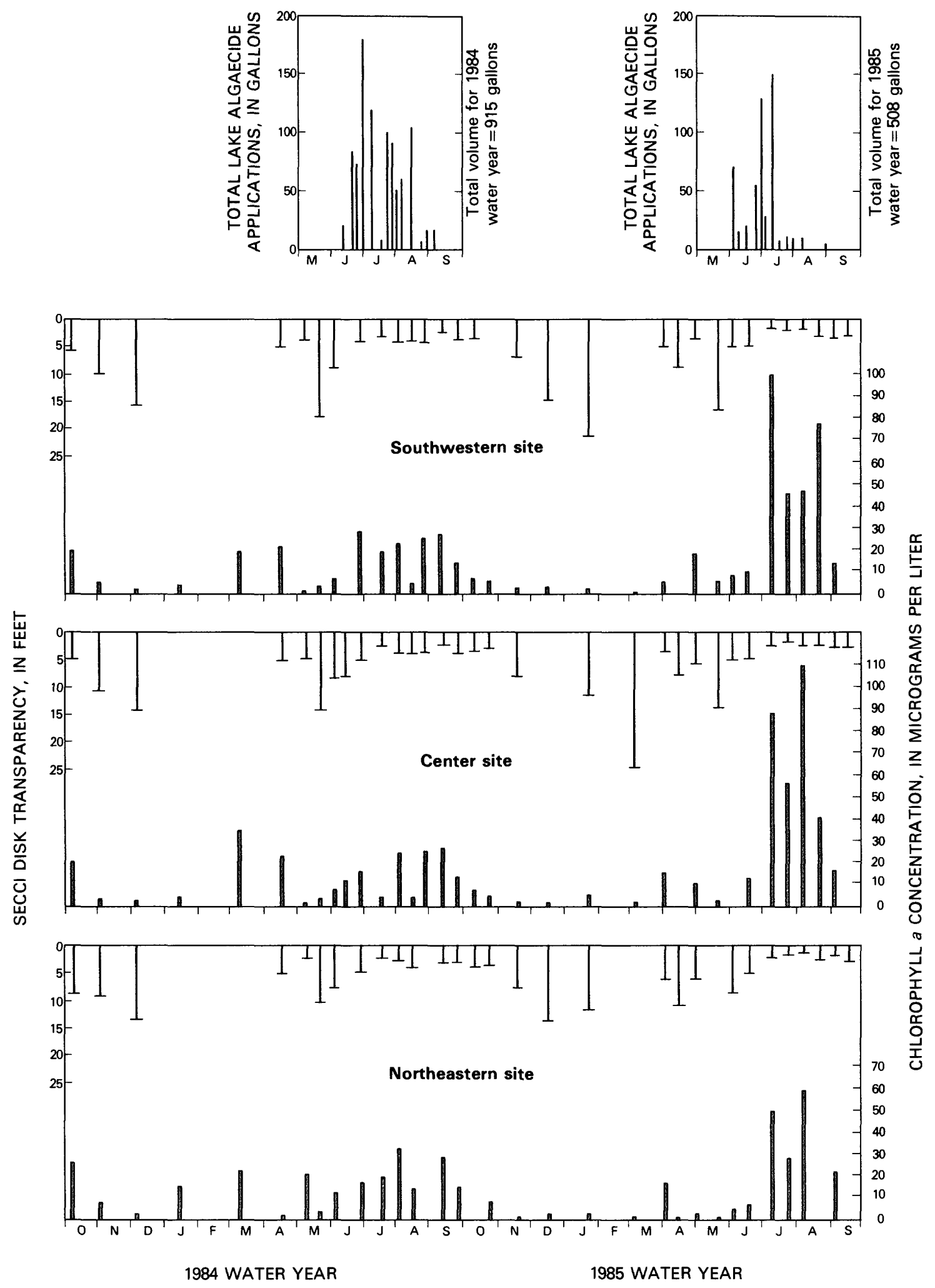

Figure 18. Secchi disc transparencies, chlorophyll $a$ concentrations, and chelated copper application for Delavan Lake, 1984 and 1985 water years. 
1984 WATER YEAR

SOUTHWEST END

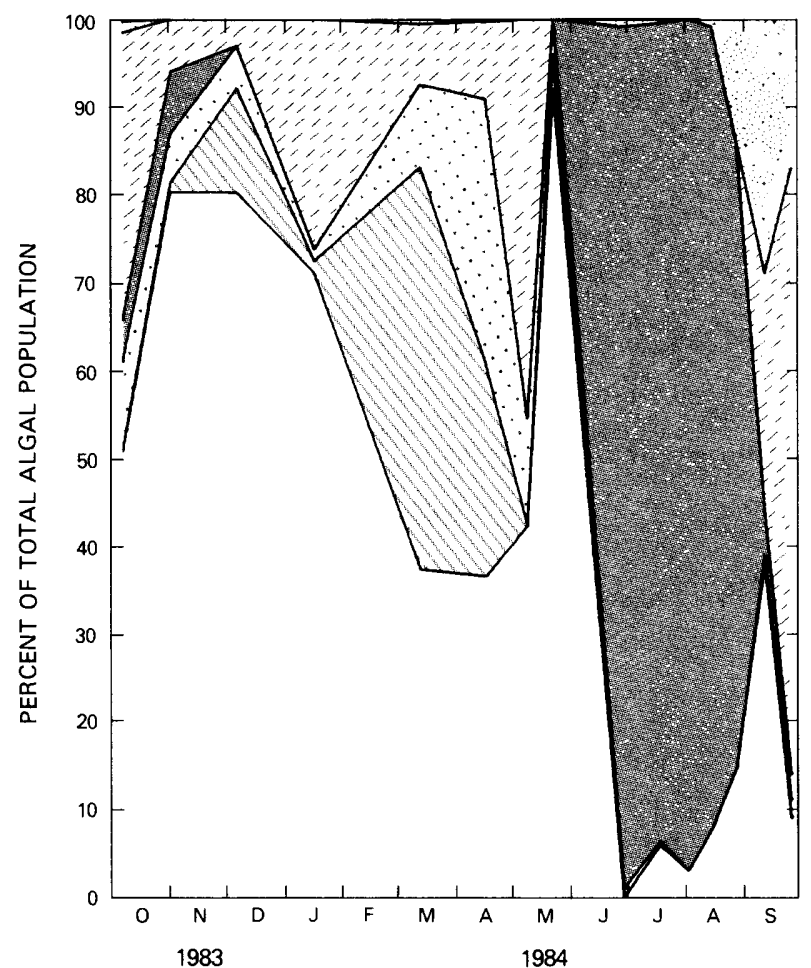

NORTHEAST END

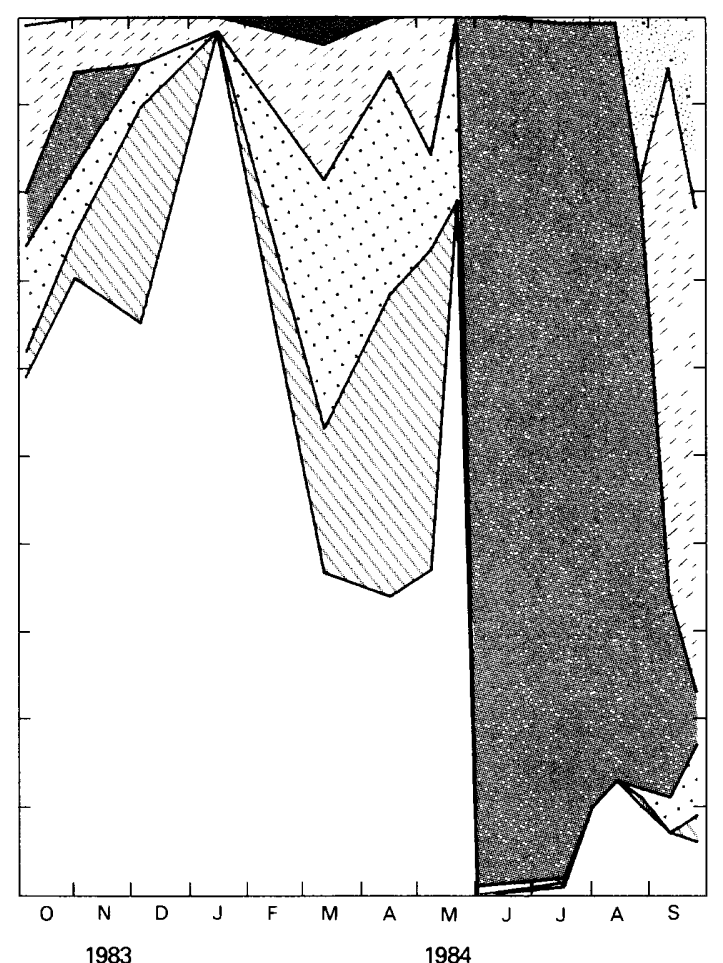

1985 WATER YEAR
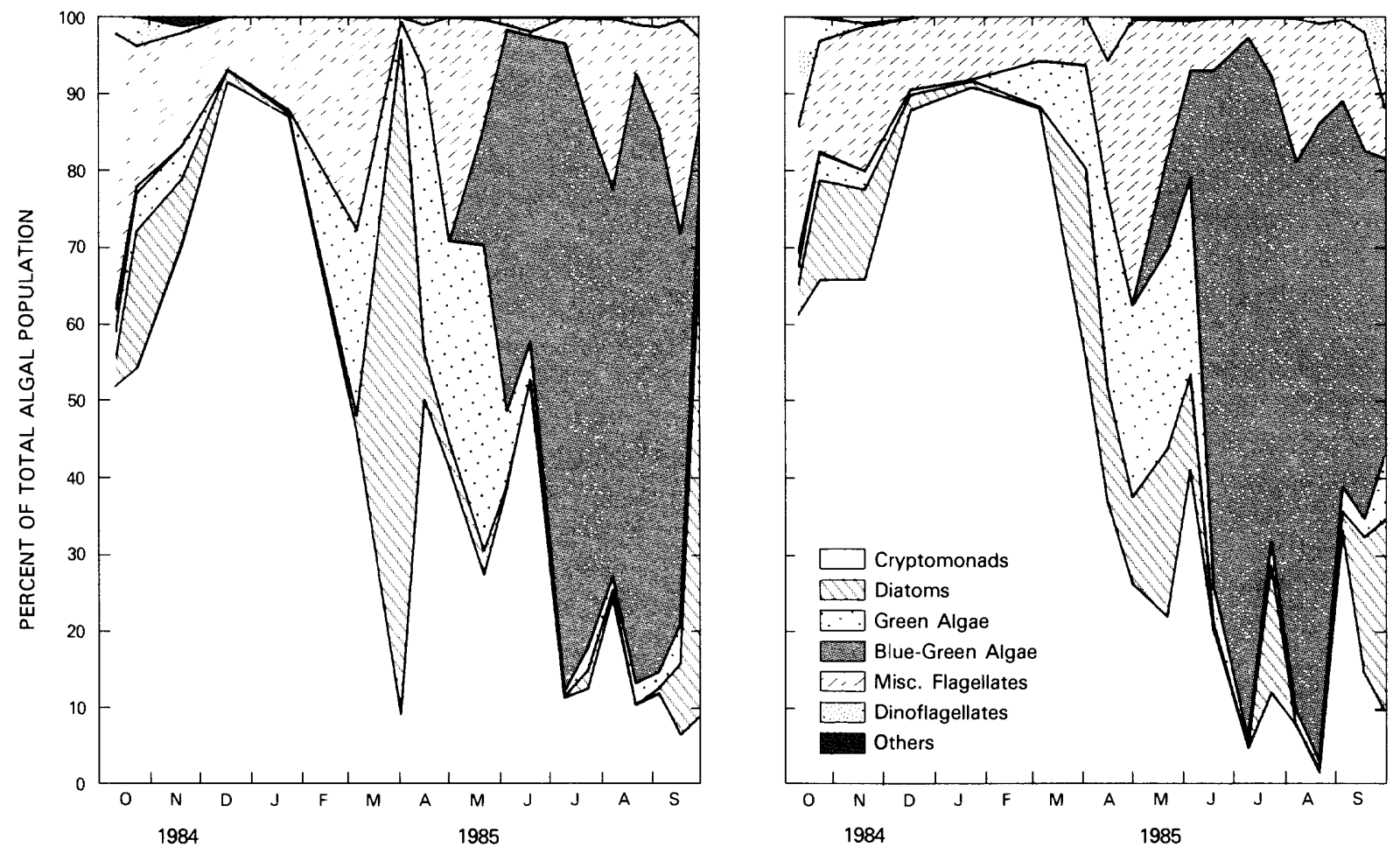

Note: Percnt of total algal population is based numerical abundance rather than biomass.

Figure 19. Types of algae in Delavan Lake, 1984 and 1985 water years. 
Aphanizomenon flos-aqua dominated 78 percent of the total algal population.

Undesirable blue-green algae numerically dominate the large algal bloom in Delavan Lake during summer months because of the low nitrogen/phosphorus ratios. High phosphorus concentrations cause nitrogen/phosphorus ratios (by weight) to be low. Smith (1983) found in analysis of 17 lakes throughout the world that blue-green algae tend to be rare when the nitrogen/phosphorus ratio exceeds 29 to 1 , but he also found a dramatic tendency for blue-green algal blooms to occur when the nitrogen-phosphorus ratios fall below 29 to 1 . Smith concluded that blue-green algae are better nitrogen competitors during times of nitrate deficiency because of the heterocysts in the cell walls, but are poorer phosphorus competitors than other groups of algae.

The Cryptomonads (Cryptophyta) make up a significant part of the total population during the colder months of both study years. All members of these groups are small and little is known about their ecology or physiology (Wetzel, 1983). Algal growth in Delavan Lake during the winter months is limited to groups (Cryptophyta) that are adapted to low water temperatures and low light irradiance. As the ice cover melts in the spring and the season progresses, circulation of the water column results in mixing of the nutrient-laden water from lower depths with the top layer. Increasing light in the spring is the dominant factor contributing to spring algal blooms (Wetzel, 1983).

A minor algal peak occurred in the spring of both water years in Delavan Lake. The green algae (Chlorophyta) and the diatoms (Bacillariophyta) are codominant with the Cryptomonads in this algal bloom. The numerically dominant green alga was Chlamydomons flagellate and the numerically dominant diatoms included Cyclotella sp., Nitzschia acicularis, and Stephanodiscus tenius. S. tenius accounted for 88 percent of the large algal population peak on April 2, 1985, at the southwestern end of the lake (fig. 19).

\section{ZOOPLANKTON}

Zooplankton are microscopic animals that inhabit the same environments as phytoplankton. Zooplankton are an important link in the aquatic food chain. They feed on algae and, in turn, provide a food source for fish. During the 1984 and 1985 water years, 28 species of zooplankton were found in Delavan Lake in varying degrees of abundance, as shown in figures 20 and 21 . The total populations of all zooplankton and phytoplankton are shown in figure 22. Cydorus sphaericus is by far the most dominant species in the zooplankton community. Other lesser dominant species include: Daphnia spp. (immature), Enbosomina coregoni, and immature copepods. Two other less populous species, Daphnia galeata mendotae and Diaptomus sicilodes, also were found in almost all samplings.

The rotifers Conochiloides spp. and Synchaeta spp. are the dominant spring species. Most rotifers are nonpredatory and feed on bacteria, small algae, and particulate organic matter; most food particles eaten are small-less than $0.47 \times 10^{-3}$ in. (12 micrometers) in diameter (Wetzel, 1983). Immature copepods then dominate the zooplankton population from late April through May. The copepods are divided into three major groups: the Calanoida, Cyclopoda, and the Harpacticoida. The calanoid copepods almost exclusively feed on algae. Cyclops bicuspidatus thomasi and Mesocyclops edax are predators of other zooplankton (Cole, 1979). Diaptomus is essentially a filter feeder, straining out algal cells (Cole, 1979). The cladoceran, Chydorus sphaericus then becomes the dominant species from middle to late summer. Chydorus (and Bosmina genera) are microfiltrators; they ingest on the average of 5 to 15 percent algae, 10 to 20 percent detritus, and 70 to 80 percent bacteria (Kerfoot, 1980). Chydous sphaericus is typically found in very productive lakes.

Blue-green algae are generally unpalatable to zooplankton because they give off toxins (Wetzel, 1983). However, Schindler (1971) found that some blue-greens can be used as a food source. The zooplankton population increased and peaked in September of the 1984 water year after the blue-green population declined significantly, likely because more palatable alga (miscellaneous flagellates, dinoflagelletes, and cryptomonads) were present. However, the zooplankton population peaked in late July of the 1985 water year, probably because the blue-green algal populations did not represent almost the entire algal populations in summer and other palatable species were present. It is possible, however, that the zooplankton peaks may have been partly due to lack of predation by vertebrates on invertebrates.

\section{Macrophytes}

By Robert Wakeman, Wisconsin Department of Natural Resources

An aquatic macrophyte survey of Delavan Lake was conducted from June 12 to August 21, 1984. The survey consisted of weekly boat trips around the lake. Aquatic macrophytes were sampled, identified, and their growth and distribution were evaluated. Curly Leaf Pondweed (Potomogeton crispus) was the dominant macrophyte present during the survey period. Its distribution on June 12 and July 10 is shown in figure 23 . The most significant growth occurred along the south shore and was limited to water less than $10 \mathrm{ft}$ deep. The plants had developed seed heads and looked healthy by June 20 . Its maximum distribution was noted on June 26 . The plants had deteriorated noticeably by July 10 and had completely died off by August 14. Natural die off of Curly Leaf Pondweed commonly occurs by midAugust.

Two other types of aquatic macrophytes were present during the survey period, White Water Lily (Nymphaea spp.) and an unidentified pondweed (Potomogeton spp.). Neither plant was a significant component of the macrophyte population. The water lilies were confined to the shallow bay at the southwestern end of the lake and the unidentified pondweed was found at the northern edge (see fig. 23 for distributions). 

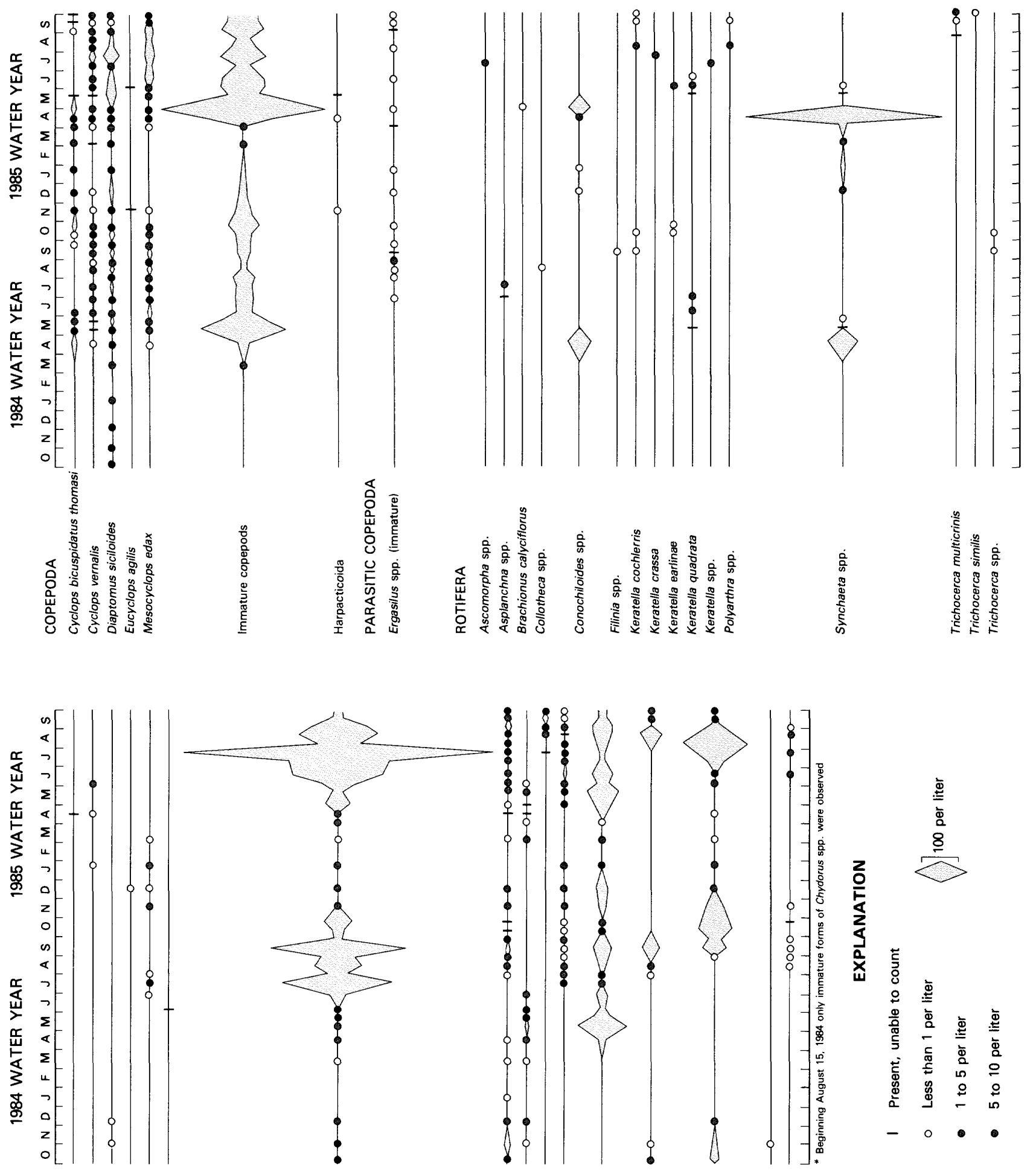

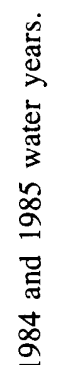

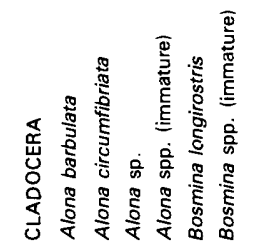

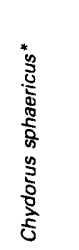

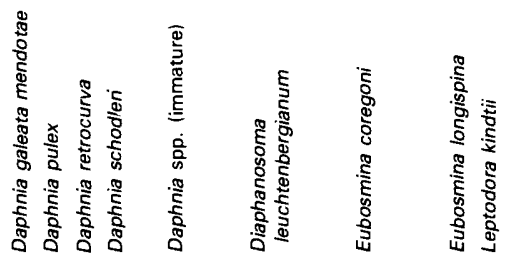



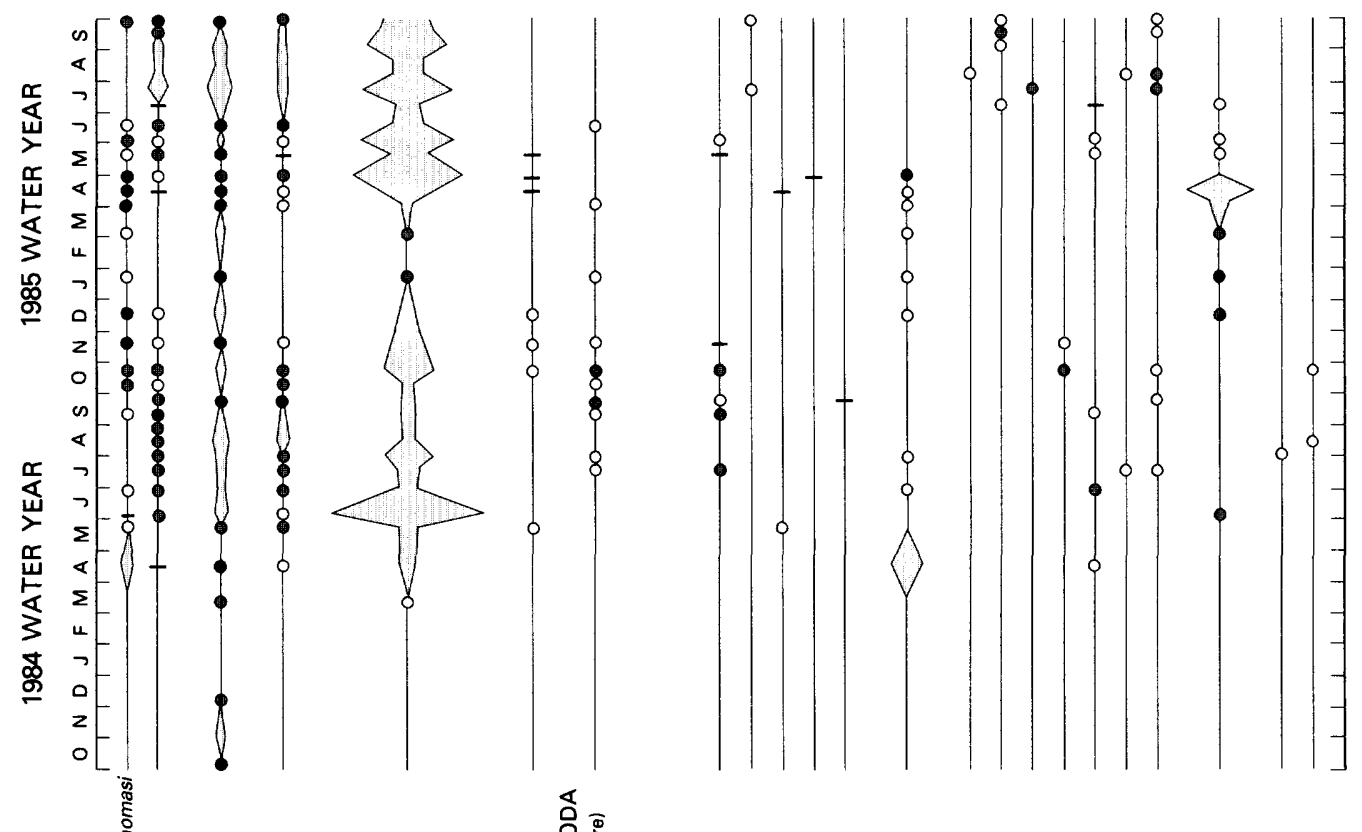

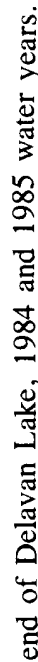

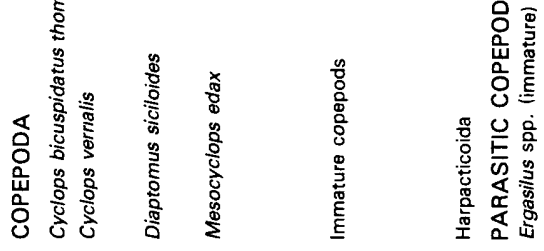
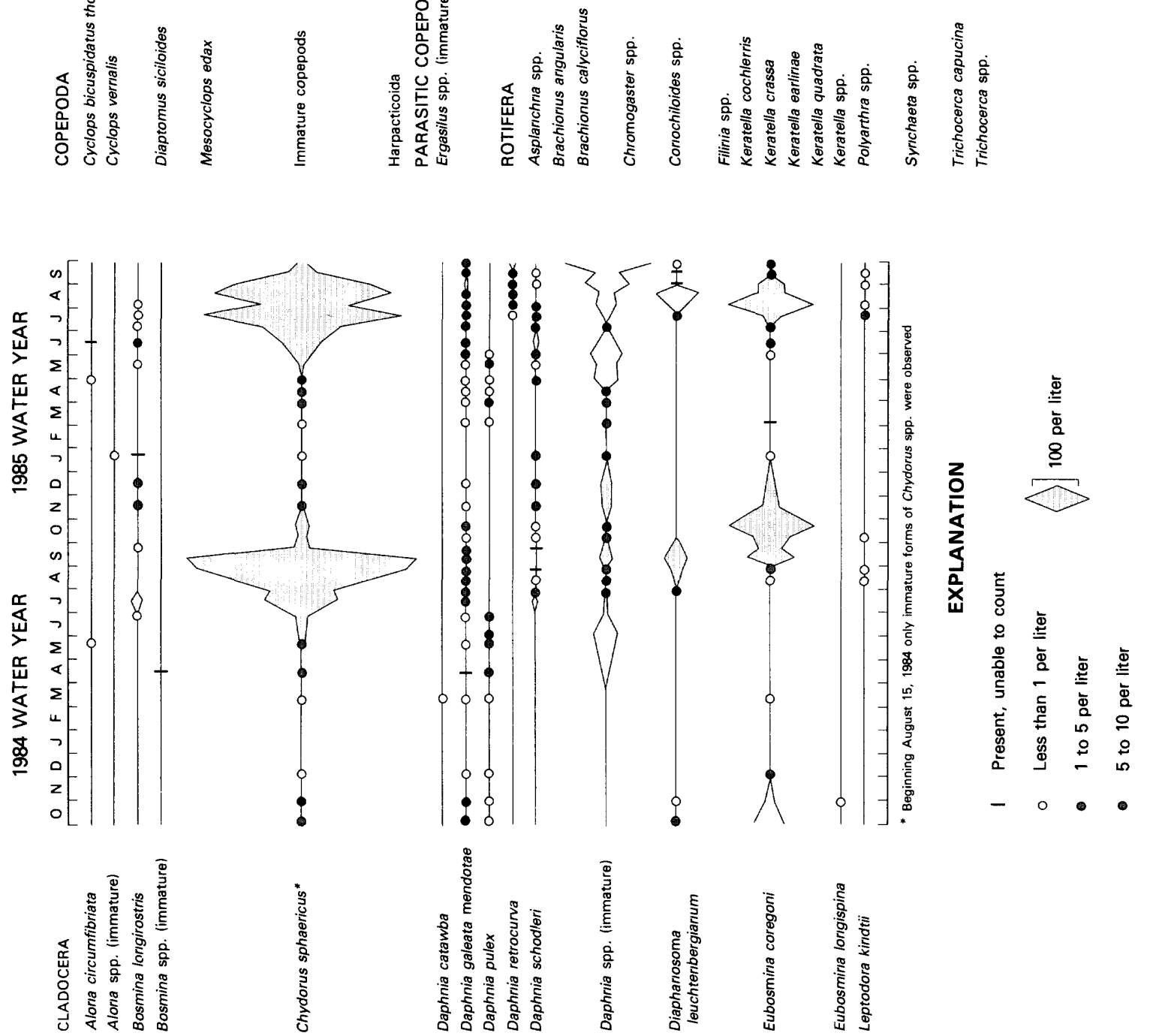

แn! $\mid$ 
Phytoplankton 1984 and 1985 Water Years

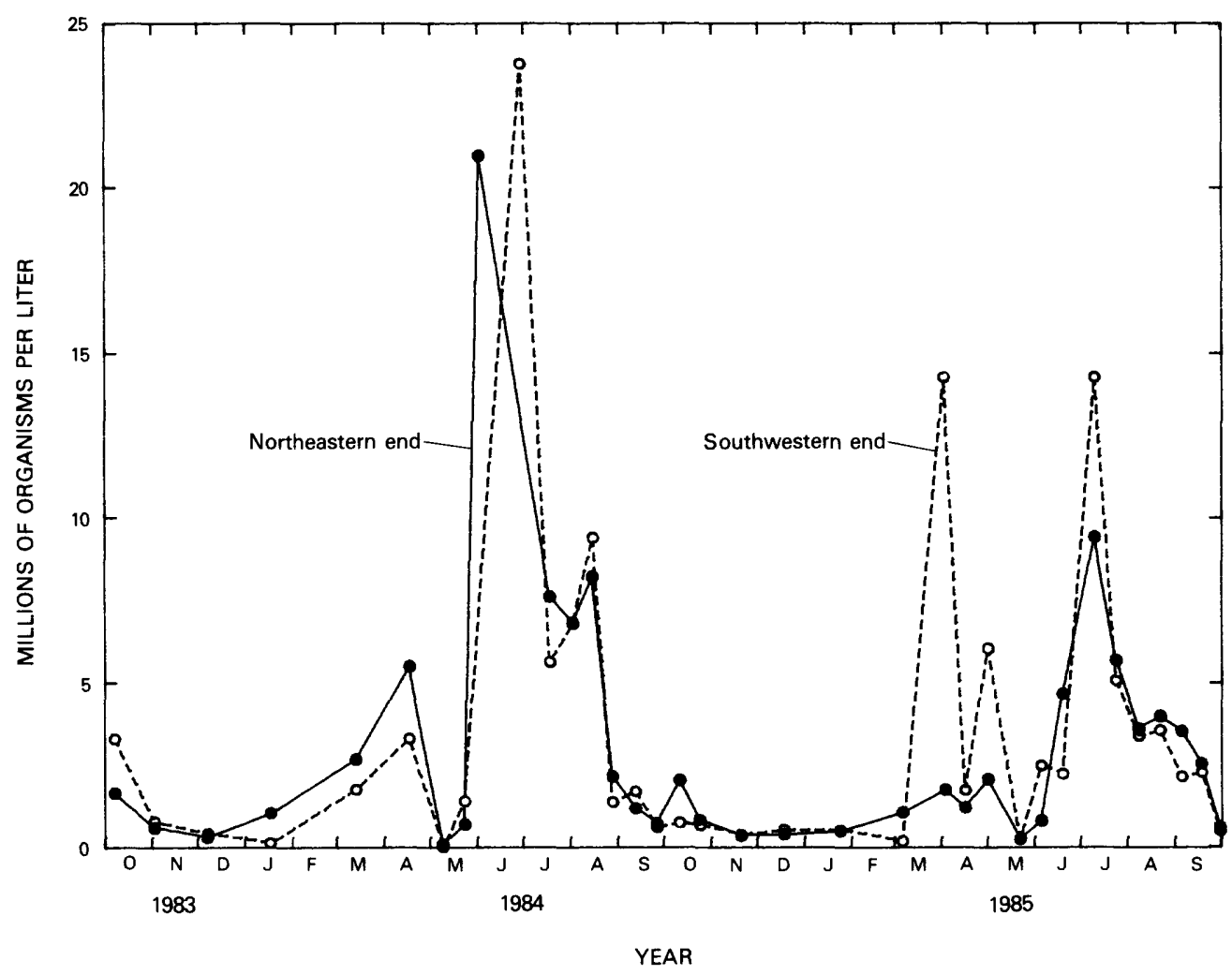

Zooplankton 1984 and 1985 Water Years

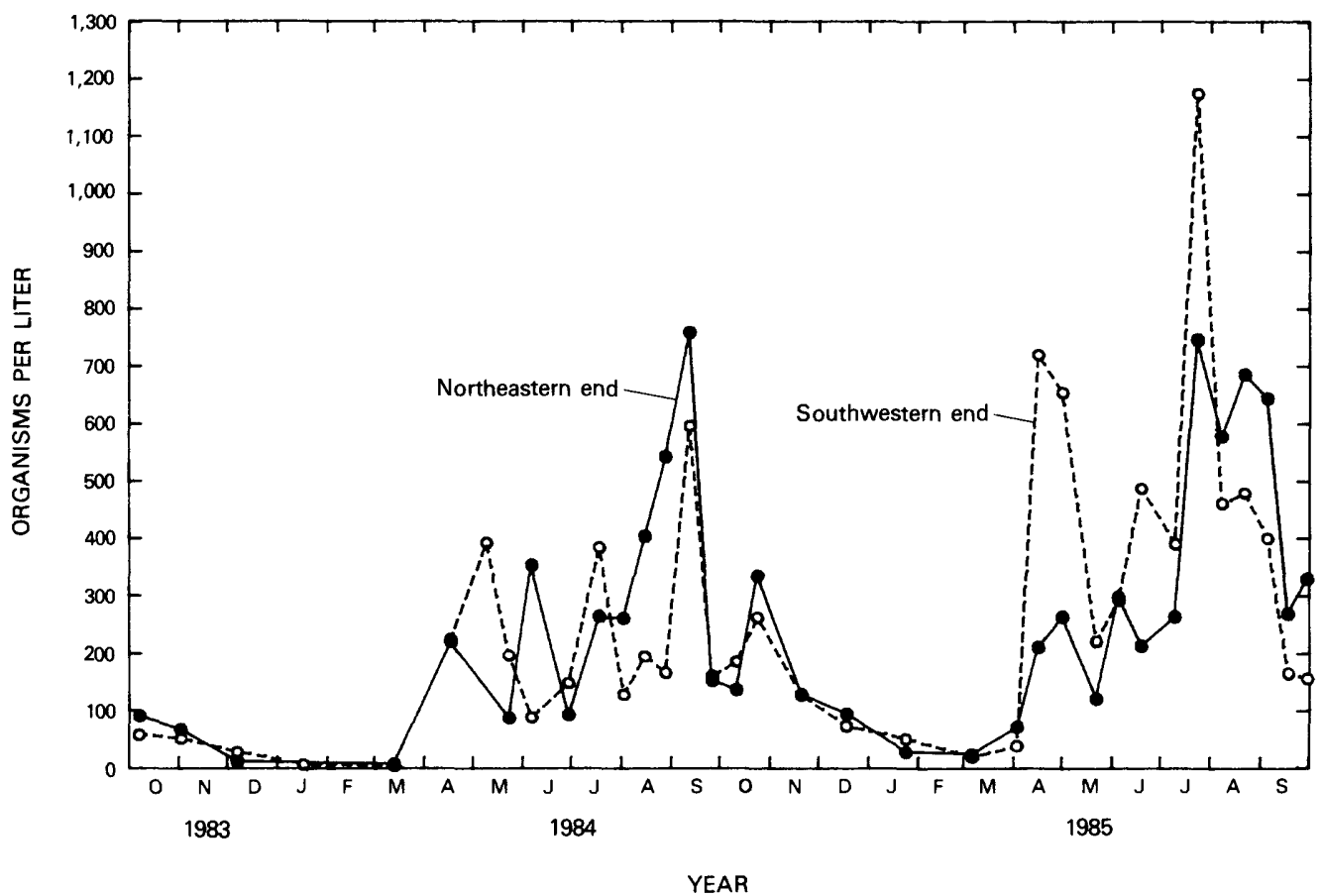

Figure 22. Total population of phytoplankton and zooplankton, Delavan Lake, 1984 and 1985 water years. 


\section{EXPLANATION}

Macrophytes, predominately Curly leaf pondweed (Potomogeton crispus)

Curly leaf pondweed (Potomogeton crispus)

Narrow leaf pondweed (Potomogeton sp.)

White water lily (Nymphaea $s p$. )

- Patchy growth
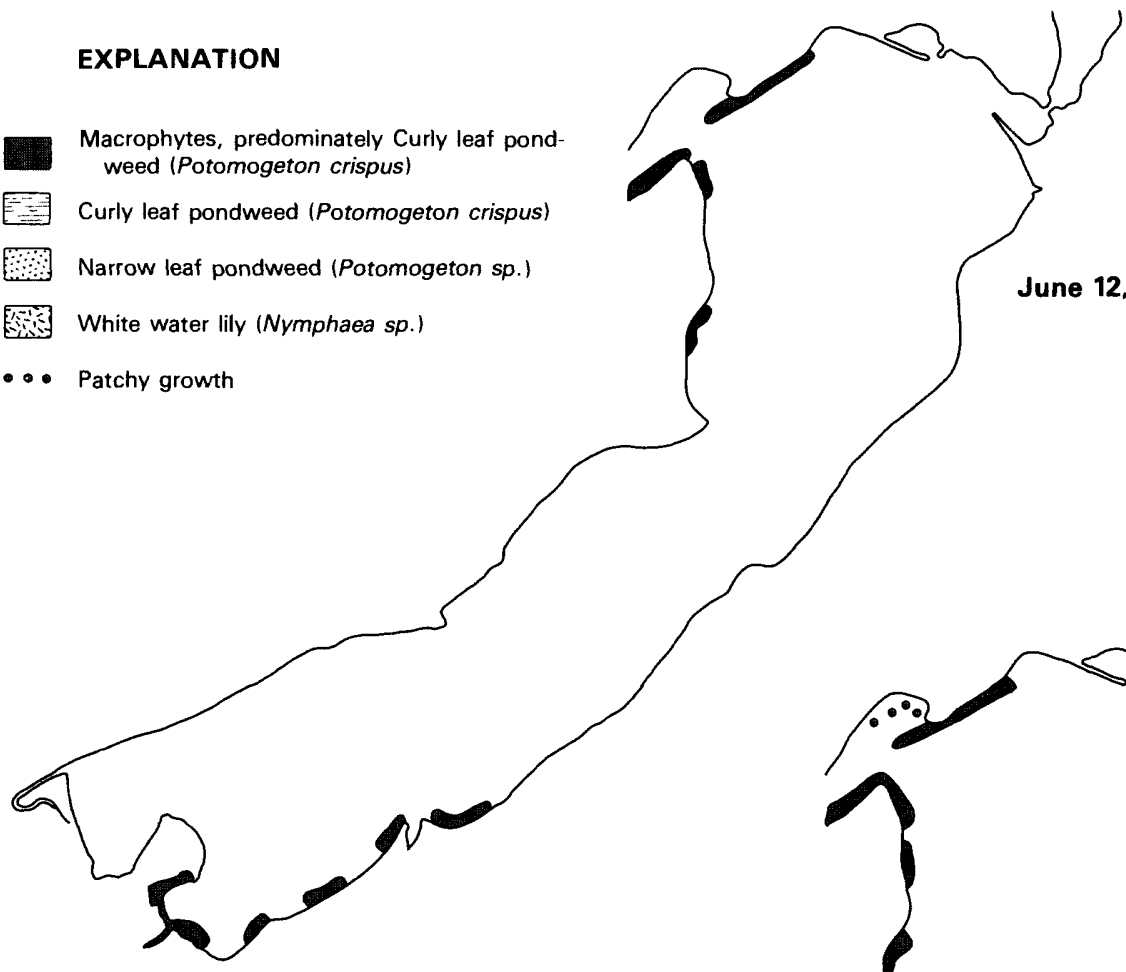

June 12, 1984
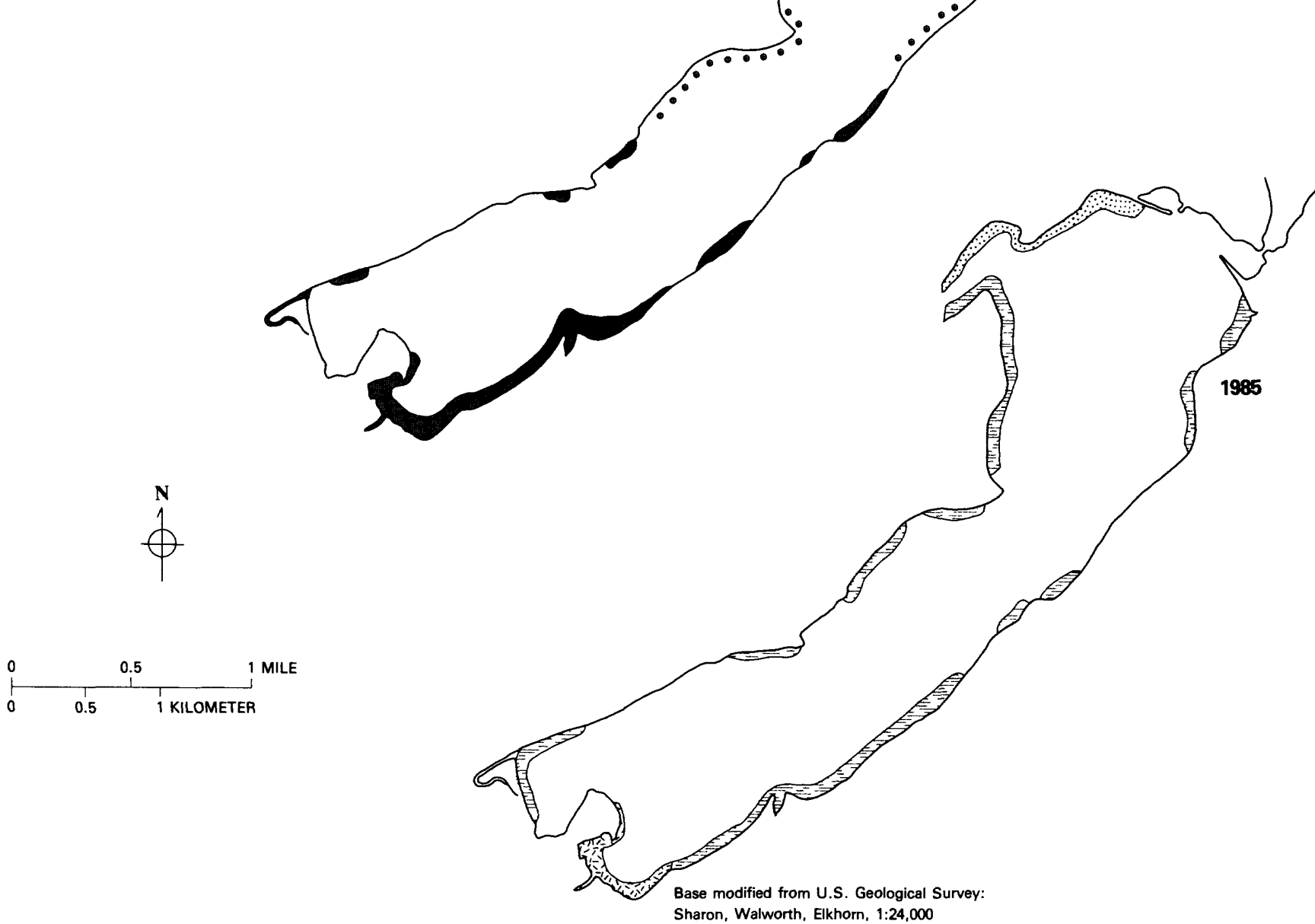

Figure 23. Distribution of macrophytes, June 12 and July 10, 1984, and 1985. 
The presence of aquatic macrophytes represents an important change in the primary production of Delavan Lake. Since the late 1950's the lake has been virtually devoid of aquatic macrophytes due to intense shading by planktonic algae.

A second aquatic macrophyte survey of Delavan Lake was conducted from May 21 to August 27, 1985. Aquatic macrophytes were observed during weekly trips around the lake. This survey was limited at times by severe planktonic algae blooms that made visual observation impossible.

Figure 23 shows the aquatic macrophyte species distribution in Delavan Lake. Comparison of the 1985 distribution to the 1984 results shows similar species composition and distribution. The dominant species during 1985 was still Potomogeton crispus; it was found intermittently along the north and south shores. The densest growth occurred at the west end and in the channels. The unidentified pondweed (Potomogeton sp.) was more difficult to evaluate during 1985 due to its less prominent stature. This narrow leafed pondweed was found at the inlet and in the northern bay at the northern end of the lake. White water lily (Nymphaea sp.) was found in the extreme southwestern corner of the lake. Although elodea was not found in Delavan Lake, it has been reported present in the shallow bay at the southwestern end of Delavan Lake.

The continued success of Potomogeton crispus is contingent on good water clarity in the spring. This species grows quickly under the ice during late winter and continues in the spring. The plant dies by late July or August. The water clarity is limiting during July and August and is likely to limit other aquatic macrophytes that are more adapted to growth during this time of year.

\section{Bottom Sediments}

\section{BENTHIC MACROINVERTEBRATES}

Benthic macroinvertebrates are the organisms that live in and on the bottom sediments. The sampling sites are shown in figure 4 and the total number of organisms is shown in table 10 .

The number of organisms found in the bottom sediments of Delavan Lake is low compared to other lakes in the area. Hanson and Stefan (1984) summarized benthic macroinvertebrate data of other researchers that is a valuable comparison for the Delavan Lake data. Delavan Lake averaged 707 organisms per square meter compared to 7,567 for Lake Mendota, 1,109 for Lake Monona, 1,979 for Nagawicka Lake, and 1,623 for Pewaukee Lake. Lakes Mendota and Monona are in Madison about 60 mi northwest of Delavan Lake, and Nagawicka and Pewaukee Lakes are near Waukesha about 35 mi northeast of Delavan Lake.

The reason for the very low benthic macroinvertebrate population of Delavan Lake is not apparent but does not appear to be caused by copper accumulations in the Delavan Lake sediments from the spraying of the chelated copper to control algae. Wakeman (1985), in his survey of the Delavan Lake sediments in 1982 and 1984, found that the top 8 in. of sediment contained less than $100 \mathrm{mg} / \mathrm{kg}$ copper. By com-

Table 10. Benthic macroinvertebrate count, Delavan Lake, 1984 and 1985 water years

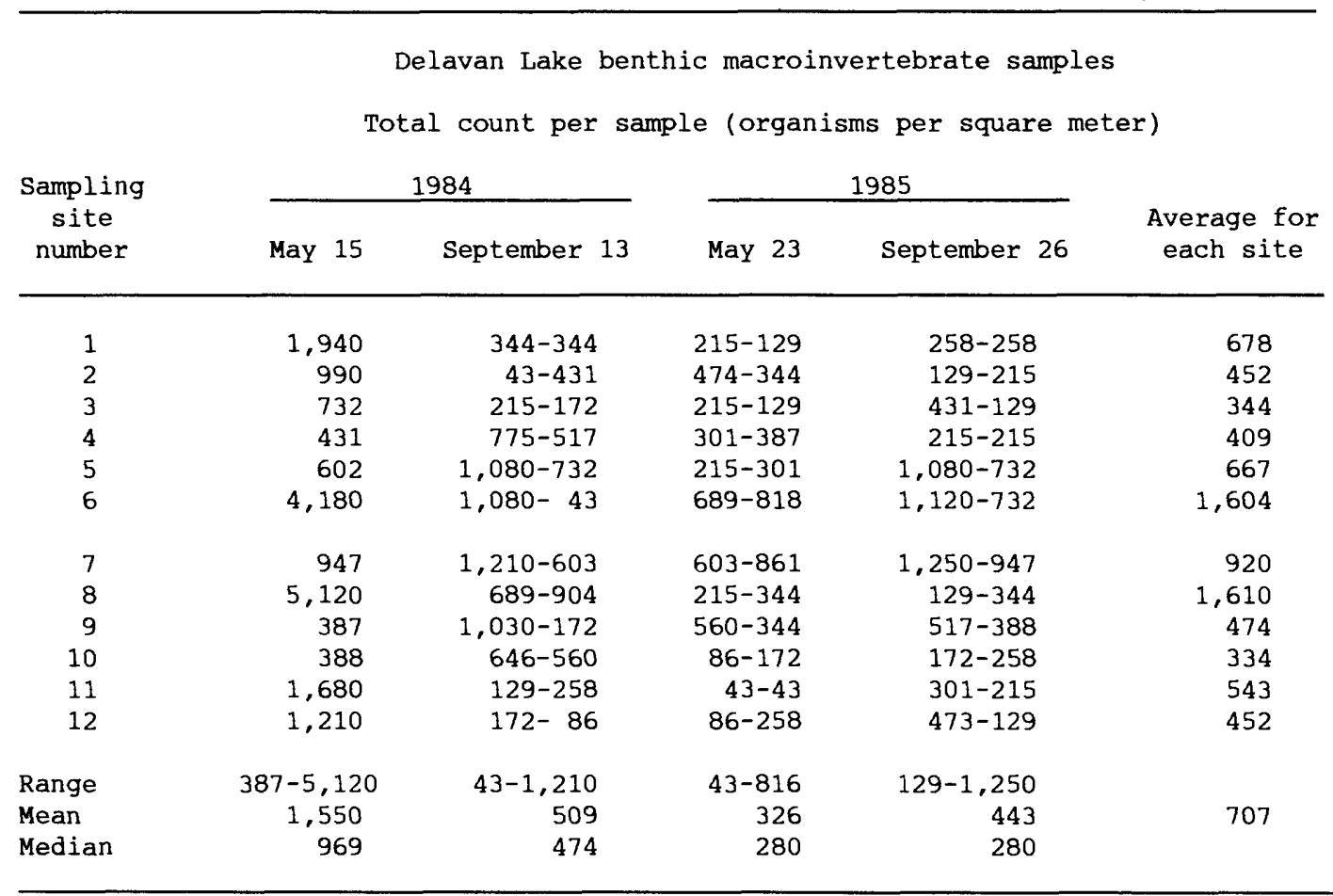


parison Lake Monona contained a mean concentration of 420 $\mathrm{mg} / \mathrm{kg}$ of copper in the bottom sediments and Fairmont Lake in 1964 in Minnesota contained copper in the sediments as high as $5,600 \mathrm{mg} / \mathrm{kg}$. Fairmont Lake was almost completely devoid of bottom organisms.

The only group of benthic fauna in any appreciable quantities in Delavan Lake are the aquatic insects-the Diptera order or flies. "As hypolimnetic strata of hypereutrophic waters undergo extreme eutrophicational or pollutional loading of organic matter essentially all of the aquatic insects may be eliminated. Practically the only group of benthic fauna adapted to conditions of extremely high organic loading is the oligochaete annelids." (Wetzel, 1983, p. 647). Oligochaetes were present in some of the samples but not in sufficient numbers to count. Of the Diptera, the Chironomidae are the only dominant group in the Delavan Lake muds and they show few density changes with watercolumn depth. Chironomid larvae possess a type of hemoglobin in their blood that functions efficiently at low oxygen concentrations (Wetzel, 1983).

\section{SEDIMENTS AT DELAVAN LAKE INLET}

The sediments at Delavan Lake inlet were surveyed to determine the quantity of soft sediments and their phosphorus, iron, manganese, and moisture content to evaluate the effectiveness of sediment dredging in the inlet to improve the lake's water quality. The Delavan Lake inlet upstream of State Highway 50 is very shallow and is less than $2 \mathrm{ft}$ deep. Depths of the soft sediments range from a mean of 1.4 to $4.4 \mathrm{ft}$. Phosphorus concentrations of the sediments are very high and well above those concentrations of $650 \mathrm{mg} / \mathrm{kg}$ considered by EPA to be indicative of "heavily polluted" water (U.S. Environmental Protection Agency, 1977). The total volume of soft sediments in the inlet (sections $1-21$ ) is $947,000 \mathrm{yd}^{3}$ (cubic yards). The sample sections, section volumes and cross-section numbers, are shown in table 11. The concentration data are shown in table 12 .

\section{NUTRIENT AND SEDIMENT SOURCES AND LOADINGS}

\section{External Loading}

\section{STREAMFLOW}

Annual nutrient and suspended-sediment loads and yields in the Delavan Lake basin are shown in tables 13 and 14 . The yields from the basins upstream of the gaging stations varied significantly, and all parameters except nitrite plus nitrate nitrogen, generally showed a reduction for the 1985 water year compared to the 1984 water year.

Of the phosphorus species only total phosphorus loads were calculated. If other phosphorus species (that is, particulate phosphorus, dissolved orthophosphate phosphorus, dissolved phosphorus) had been analyzed and loads calculated, the relationship of these species loads to those for total phosphorus may have varied considerably between basins (Elder, 1985).

\section{Jackson Creek tributary near Elkhorn}

The Jackson Creek tributary basin (fig. 3) had the greatest phosphorus, Kjeldahl nitrogen, and suspendedsediment yields of the four inflow monitoring basins. The high yields were partly caused by greater runoff (table 5) from this partly urbanized area relative to the other stations. However, they were primarily caused by the high concentrations of phosphorus, Kjeldahl nitrogen, and suspended sediments during storm runoff periods. The statistical summaries of the concentration data for the four inflow gaging stations are shown in table 15 .

Drainage area size is an important factor for the total sediment yield from a watershed. The rate of sediment delivery decreases as the size of the drainage area increases and in accordance with streamflow (Chow, 1964, section 17, p. 12). The steeper watershed slopes for smaller tributaries increases runoff and flow velocity, thereby increasing erosion. Jackson Creek tributary is the smallest of the gaged basins and has the greatest slope. Therefore sediment yields from this basin should be greater than from the other basins.

A good correlation exists between phosphorus and sediment yields because phosphorus sorbs to the sediment particle. It follows that phosphorus yields may, as sediment yields do, also be partially dependent on drainage-area size, and on watershed slope. The close association of phosphorus with sediment has been demonstrated in the Steiner Branch basin (Field and Lidwin, 1982), as well as in other basins (Verhoff and others, 1979, and Sharpley and others, 1971). This is the direct result of the transport mechanisms involved in delivering phosphorus to the stream.

Phosphorus is quickly adsorbed to the surface of soil particles, especially on the silt and clay fractions. These small particles have a greater surface area-to-volume ratio than larger diameter particles and are, thus, more efficient transporters of phosphorus. When soil is eroded during a rain storm, the sorbed phosphorus is transported to the stream with soil particles. The relation of phosphorus and sediment yields at the four inflow gaging stations compared to those yields for stations, in nonpoint pollution studies in the southern half of Wisconsin are shown in figure 24 (Field and Lidwin, 1982; Field, 1984, 1985, and 1986). The phosphorus yields at Jackson Creek tributary plot considerably above the regression line and indicate that the higher phosphorus yields are likely not related to the sediment yields in the basin. There are, point sources of pollution within the city of Elkhorn that may cause elevated phosphorus yields in this basin $(\mathrm{N}$. T . O'Reilly, Wisconsin Department of Natural Resources, oral commun., 1986).

Kjeldahl nitrogen is composed of ammonia nitrogen and organic nitrogen. Although no separate analyses were obtained for the individual components of ammonia nitrogen and organic nitrogen, other Wisconsin studies by the author in the Onion River basin, Sheboygan County (Field, 1984), Elk Creek basin, Trempealeau County (Field, 1985), and the Steiner Branch basin, Lafayette County (Field and Lidwin, 1982) have shown that organic nitrogen is the major 
Table 11. Results and sites of sediment survey of Delavan Lake inlet

\begin{tabular}{rccc}
\hline Section & $\begin{array}{c}\text { Mean sediment } \\
\text { depth } \\
\text { (feet) }\end{array}$ & $\begin{array}{c}\text { Area } \\
\text { (thousands of } \\
\text { square feet) }\end{array}$ & $\begin{array}{c}\text { Volume } \\
\text { (thousands of } \\
\text { cubic feet) }\end{array}$ \\
\hline 1 & 1.38 & 154 & 213 \\
2 & 1.83 & 461 & 843 \\
3 & 3.61 & 50 & 2,060 \\
4 & 3.19 & 488 & 1,560 \\
5 & 2.87 & 602 & 1,730 \\
6 & 2.52 & 717 & 1,810 \\
7 & 1.84 & 596 & 1,100 \\
8 & 3.53 & 623 & 2,220 \\
9 & 3.52 & 169 & 593 \\
10 & 4.21 & 281 & 1,180 \\
11 & & & 1,410 \\
12 & 3.66 & 386 & 1,670 \\
13 & 3.09 & 542 & 3,060 \\
14 & 3.87 & 790 & 862 \\
15 & 2.85 & 303 & 2,270 \\
16 & 4.44 & 512 & 618 \\
17 & 3.48 & 178 & 341 \\
18 & 3.02 & 113 & 559 \\
19 & 3.70 & 151 & 304 \\
20 & 3.20 & 95 & 493 \\
21 & 3.70 & 133 & 674 \\
& 3.75 & & 25,570 \\
& & &
\end{tabular}

Total volume of soft sediments: 947,000 cubic yards

${ }^{1}$ Mean depth of cross section across channel.

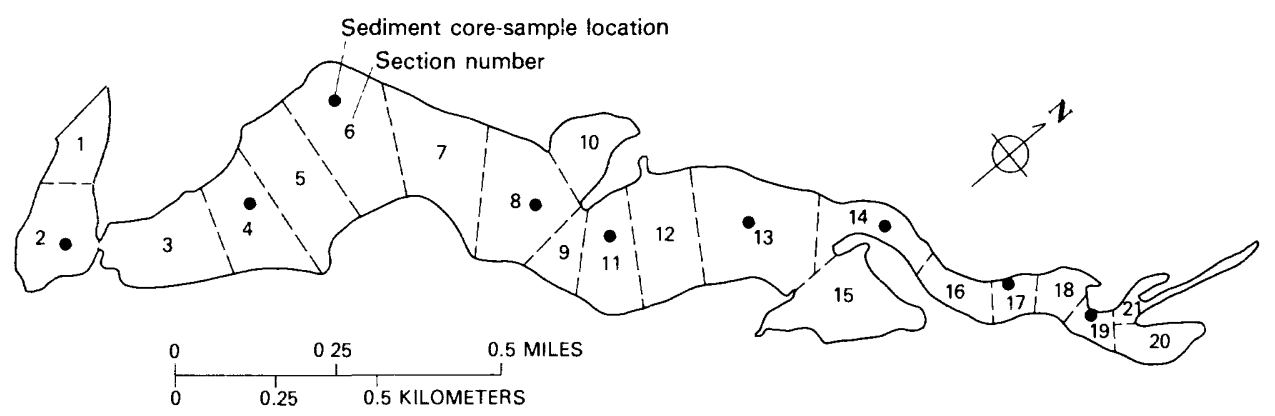


Table 12. Delavan Lake inlet sediment characteristics

[mg/kg, milligrams per kilogram; $\mu \mathrm{g} / \mathrm{kg}$, micrograms per kiligram; a double dash indicates data unavailable]

\begin{tabular}{|c|c|c|c|c|c|c|c|c|}
\hline 1984 & $\begin{array}{l}\text { Cross } \\
\text { section } \\
\text { number }\end{array}$ & $\begin{array}{c}\text { Distance } \\
\text { upstream from } \\
\text { State Highway } 50 \\
\text { (in feet) }\end{array}$ & $\begin{array}{c}\text { Distance } \\
\text { from left bank } \\
\text { (LB) or right } \\
\text { bank (RB) } \\
\text { (in feet) }\end{array}$ & $\begin{array}{c}\text { Core } \\
\text { depth } \\
\text { interval } \\
\text { (feet) }\end{array}$ & $\begin{array}{c}\text { Phosphorus } \\
\text { concentration } \\
(\mathrm{mg} / \mathrm{kg})\end{array}$ & $\begin{array}{c}\text { Iron } \\
\text { concentration } \\
(\mu \mathrm{g} / \mathrm{g})\end{array}$ & $\begin{array}{c}\text { Manganese } \\
\text { concentration } \\
(\mu \mathrm{g} / \mathrm{g})\end{array}$ & $\begin{array}{r}\text { Moisture } \\
\text { content } \\
\text { (percent) }\end{array}$ \\
\hline & & & & $0-1$ & 1,500 & 11,000 & & \\
\hline \multirow[t]{2}{*}{ August 1} & 2 & 400 & 345 (RB) & $1-2$ & 510 & 8,600 & & \\
\hline & & (downstream) & & $2-3$ & 380 & 6,900 & & \\
\hline \multirow[t]{2}{*}{ August 1} & 6 & 2,000 & 340 (RB) & $0-1$ & 1,900 & 1,100 & & \\
\hline & & & & $1-2$ & 1,300 & 14,000 & & \\
\hline \multirow[t]{2}{*}{ August 1} & 8 & 3,700 & Channel & $0-1$ & 2,300 & 8,000 & & \\
\hline & & & center & $1-1.8$ & 1,700 & 5,200 & & \\
\hline \multirow[t]{2}{*}{ August 1} & 13 & 5,500 & Channel & $0-1$ & 1,200 & 13,000 & & \\
\hline & & & center & $1-2$ & 1,300 & 18,000 & & \\
\hline \multirow[t]{2}{*}{ August 2} & 14 & 6,400 & 120 (RB) & $0-1$ & 1,700 & 10,000 & & \\
\hline & & & & $1-2$ & 710 & 7,900 & & \\
\hline \multirow[t]{2}{*}{ August 2} & 19 & 8,300 & 40 (RB) & $0-1$ & 2,200 & 6,800 & & \\
\hline & & & & $1-1.4$ & 1,900 & 9,500 & & \\
\hline \multirow[t]{3}{*}{ August 1,2} & 4 & 1,200 & 360 (LB) & -- & -- & -- & & \\
\hline & 11 & 4,400 & 350 (RB) & -- & -- & -- & & \\
\hline & 17 & 7,700 & 40 (RB) & -- & -- & -- & & \\
\hline August 1,2 & $\begin{array}{c}\text { Composite } \\
4,11,17\end{array}$ & & & $0-1$ & 990 & 7,000 & 200 & 60 \\
\hline August 1,2 & $\begin{array}{c}\text { Composite } \\
4,11,17\end{array}$ & & & $1-2$ & 620 & 4,000 & 110 & 40 \\
\hline August 1,2 & $\begin{array}{c}\text { Composite } \\
4,11\end{array}$ & & & $2-3$ & 1,200 & 6,500 & 220 & 73 \\
\hline
\end{tabular}

${ }^{1}$ Right bank and left bank are determined looking downstream.

component of Kjeldahl nitrogen. This is also assumed to be the same with the organic nitrogen component of Kjeldahl nitrogen in the Delavan Lake inflow basins. The transport mechanisms for organic nitrogen may be similar to those for phosphorus and as a result the Kjeldahl nitrogen yields are high.

Nitrate yields in the Jackson Creek tributary basin are comparable to those in the Jackson Creek basin. Nitrate concentrations generally are highest during base flow and decrease with increasing discharge. Nitrate nitrogen is a readily soluble form of nitrogen. It can leach through the soil profile with precipitation, percolate to the ground-water reservoir, and eventually discharge to a surface-water body. Therefore, it is expected that most of the nitrate nitrogen would be contributed by base flow. Field and Lidwin (1982) found that 75 percent of the nitrate nitrogen load was associated with base flow.

\section{Jackson Creek at Petrie Road near Elkhorn}

The basin upstream of Jackson Creek at Petrie Road near Elkhorn contains the greatest density of livestock of the basins monitored. Despite this potential source of nutrients, phosphorus and Kjeldahl nitrogen yields were lower than those from the Jackson Creek tributary basin. Nitrate yields were comparable to those in the Jackson Creek tributary basin.

\section{Delavan Lake Inlet}

The total phosphorus yield of $323 \mathrm{lb} / \mathrm{mi}^{2}$ in the 1984 water year and $309 \mathrm{lb} / \mathrm{mi}^{2}$ in the 1985 water year at Jackson Creek at the Delavan Lake inlet may be somewhat in error but the yields appear reasonable compared to the yields 
Table 13. Nutrient and suspended-sediment loads and yields in the Delavan Lake drainage basin, 1984 water year [mi ${ }^{2}$, square miles; lbs, pounds; $] \mathrm{bs} / \mathrm{mi}^{2}$, pounds per square $\mathrm{mile}$; tons $/ \mathrm{mi}^{2}$, tons per square mile; $\mathrm{mg} / \mathrm{L}$, milligrams per liter; $\mathrm{ft}^{3} / \mathrm{s}-\mathrm{d}$, cubic feet per second per day; a double dash indicates data unavailable]

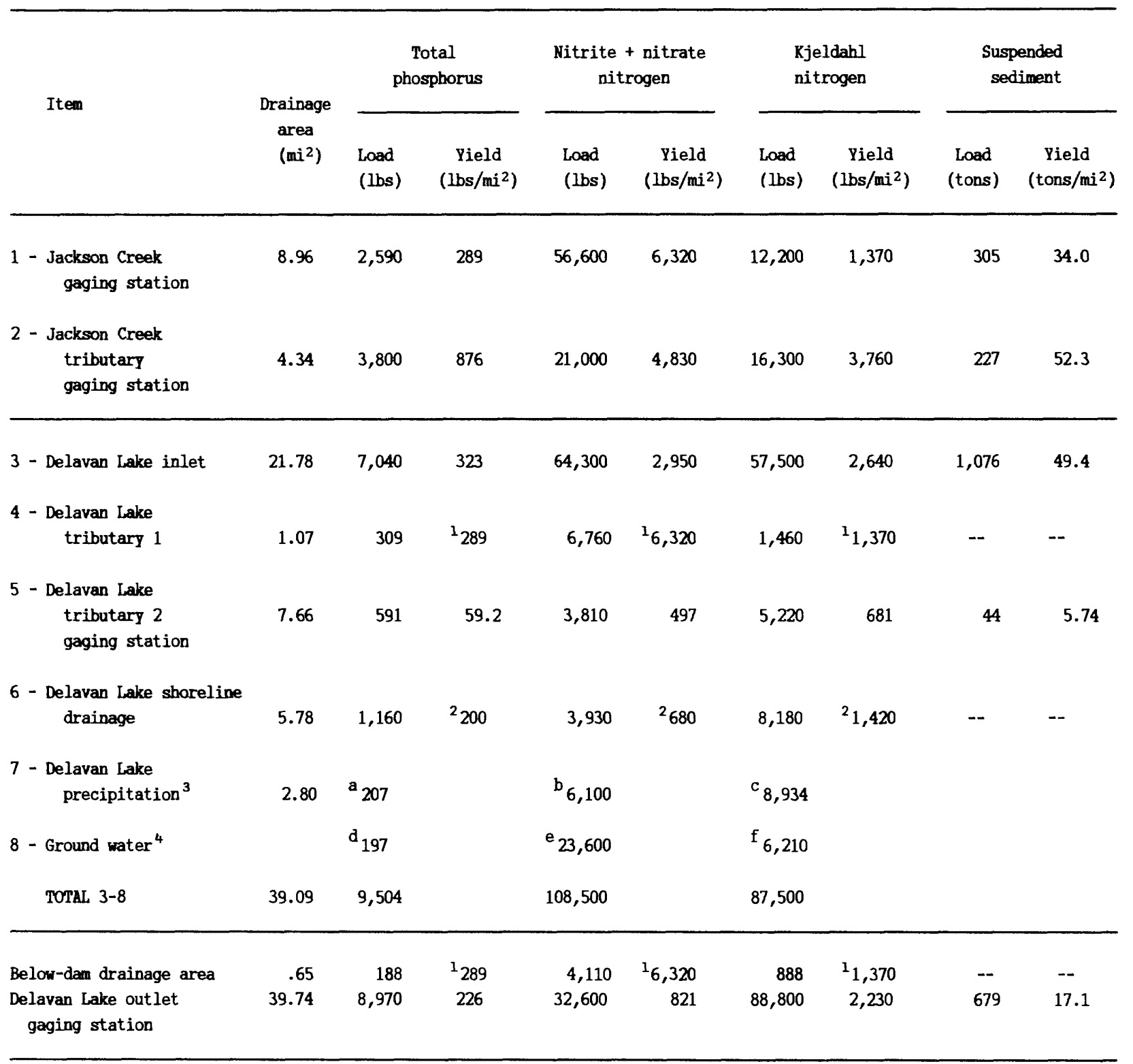

${ }^{1}$ Based on Jackson Creek.

${ }^{2}$ Reckhow, 1980; Much and Kenp, 1978.

${ }^{3}$ Based on precipitation of 31.56 inches.

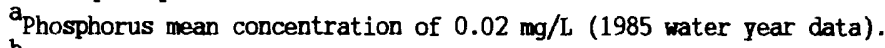

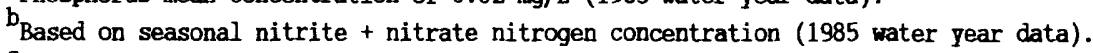

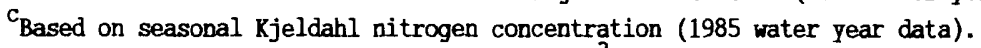

${ }^{4}$ Based on ground-water contribution of $1,824\left[\left(\mathrm{ft}^{3} / \mathrm{s}\right)-\mathrm{d}\right]$.

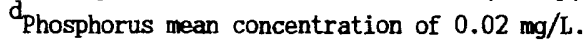

Nitrite + nitrate nitrogen mean concentration of $2.4 \mathrm{mg} / \mathrm{L}$.

$\mathrm{f}_{\mathrm{Kjeldahl}}$ nitrogen mean concentration of $0.63 \mathrm{mg} / \mathrm{L}$. 
Table 14. Nutrient and suspended-sediment loads and yields in the Delavan Lake drainage basin, 1985 water year [mi ${ }^{2}$, square miles; lbs, pounds; lbs/mi ${ }^{2}$, pounds per square mile; tons/mi ${ }^{2}$, tons per square mile; $\mathrm{mg} / \mathrm{L}$, milligrams per liter; $\mathrm{ft}^{3} / \mathrm{s}-\mathrm{d}$, cubic feet per second per day; a double dash indicates data unavailable]

\begin{tabular}{|c|c|c|c|c|c|c|c|c|c|}
\hline \multirow{2}{*}{ Iten } & \multirow{2}{*}{$\begin{array}{c}\text { Drainage } \\
\text { area } \\
\left(\mathbf{m i}^{2}\right)\end{array}$} & \multicolumn{2}{|c|}{$\begin{array}{l}\text { Total } \\
\text { phosphorus }\end{array}$} & \multicolumn{2}{|c|}{$\begin{array}{c}\text { Nitrite + nitrate } \\
\text { nitrogen }\end{array}$} & \multicolumn{2}{|c|}{$\begin{array}{l}\text { Kjeldahl } \\
\text { nitrogen }\end{array}$} & \multicolumn{2}{|c|}{$\begin{array}{r}\text { Suspended } \\
\text { sediment }\end{array}$} \\
\hline & & $\begin{array}{l}\text { Load } \\
\text { (lbs) }\end{array}$ & $\begin{array}{c}\text { Yield } \\
\left(1 \mathrm{bs} / \mathrm{mi}^{2}\right)\end{array}$ & $\begin{array}{l}\text { Load } \\
\text { (lbs) }\end{array}$ & $\begin{array}{c}\text { Yield } \\
\left(\mathrm{lbs} / \mathrm{mi}^{2}\right)\end{array}$ & $\begin{array}{l}\text { Load } \\
\text { (lbs) }\end{array}$ & $\begin{array}{c}\text { Yield } \\
\left(\mathrm{lbs} / \mathrm{mi}^{2}\right)\end{array}$ & $\begin{array}{l}\text { Load } \\
\text { (tons) }\end{array}$ & $\begin{array}{c}\text { Yield } \\
\left(\text { tons } / \mathrm{mi}^{2}\right)\end{array}$ \\
\hline $\begin{array}{l}1 \text { - Jackson Creek } \\
\text { gaging station }\end{array}$ & 8.96 & 2,340 & 261 & 51,500 & 5,750 & 10,600 & 1,180 & 206 & 23.0 \\
\hline $\begin{array}{c}2 \text { - Jackson Creek } \\
\text { tributary } \\
\text { gaging station }\end{array}$ & 4.34 & 3,480 & 801 & 25,100 & 5,780 & 14,900 & 3,430 & 407 & 93.7 \\
\hline 3 - Delavan Lake inlet & 21.78 & 6,730 & 309 & 85,400 & 3,920 & 45,500 & 2,090 & 2,002 & 91.9 \\
\hline $\begin{array}{r}4 \text { - Delavan Lake } \\
\text { tributary } 1\end{array}$ & 1.07 & 279 & ${ }^{1} 261$ & 6,150 & ${ }^{1} 5,750$ & 1,260 & ${ }^{1} 1,180$ & -- & -- \\
\hline $\begin{array}{l}5 \text { - Delavan Lake } \\
\text { tributary } 2 \\
\text { gaging station }\end{array}$ & 7.66 & 407 & 53.1 & 4,120 & 538 & 3,210 & 419 & 120 & 15.7 \\
\hline $\begin{array}{c}6 \text { - Delavan Lake shoreli } \\
\text { drainage }\end{array}$ & 5.78 & 1,010 & ${ }^{2} 174$ & 3,900 & ${ }^{2} 675$ & 6,930 & 21,200 & -- & -- \\
\hline $\begin{array}{l}7 \text { - Delavan Lake } \\
\text { precipitation }^{3}\end{array}$ & 2.80 & 243 & & 7,340 & & 10,100 & & & \\
\hline 8 - Ground water ${ }^{4}$ & & $\mathbf{a}_{311}$ & & $\mathrm{~b}_{40,500}$ & & $c_{13,100}$ & & & \\
\hline TOTAL 3-8 & 39.09 & 8,980 & & 147,410 & & 80,100 & & & \\
\hline Below-dam drainage area & .65 & 170 & 261 & 3,740 & 5,750 & 767 & 1,180 & -- & -- \\
\hline $\begin{array}{l}\text { Delavan Lake outlet } \\
\text { gaging station }\end{array}$ & 39.74 & 7,330 & 185 & 42,100 & 1,060 & 71,500 & 1,800 & 1,530 & 38.5 \\
\hline
\end{tabular}

\footnotetext{
${ }^{1}$ Based on Jackson Creek.

${ }^{2}$ Reckhow, 1980; Much and Kemp, 1978.

${ }^{3}$ Based on precipitation of 38.87 inches.

${ }^{4}$ Based on ground-water contribution of $2,884\left[\left(\mathrm{ft}^{3} / \mathrm{s}\right)-\mathrm{d}\right]$.

${ }^{a}$ Phosphorus mean concentration of $0.02 \mathrm{mg} / \mathrm{L}$.

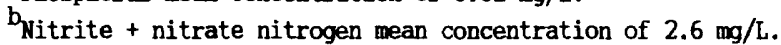

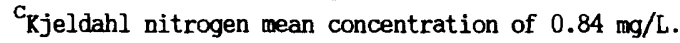




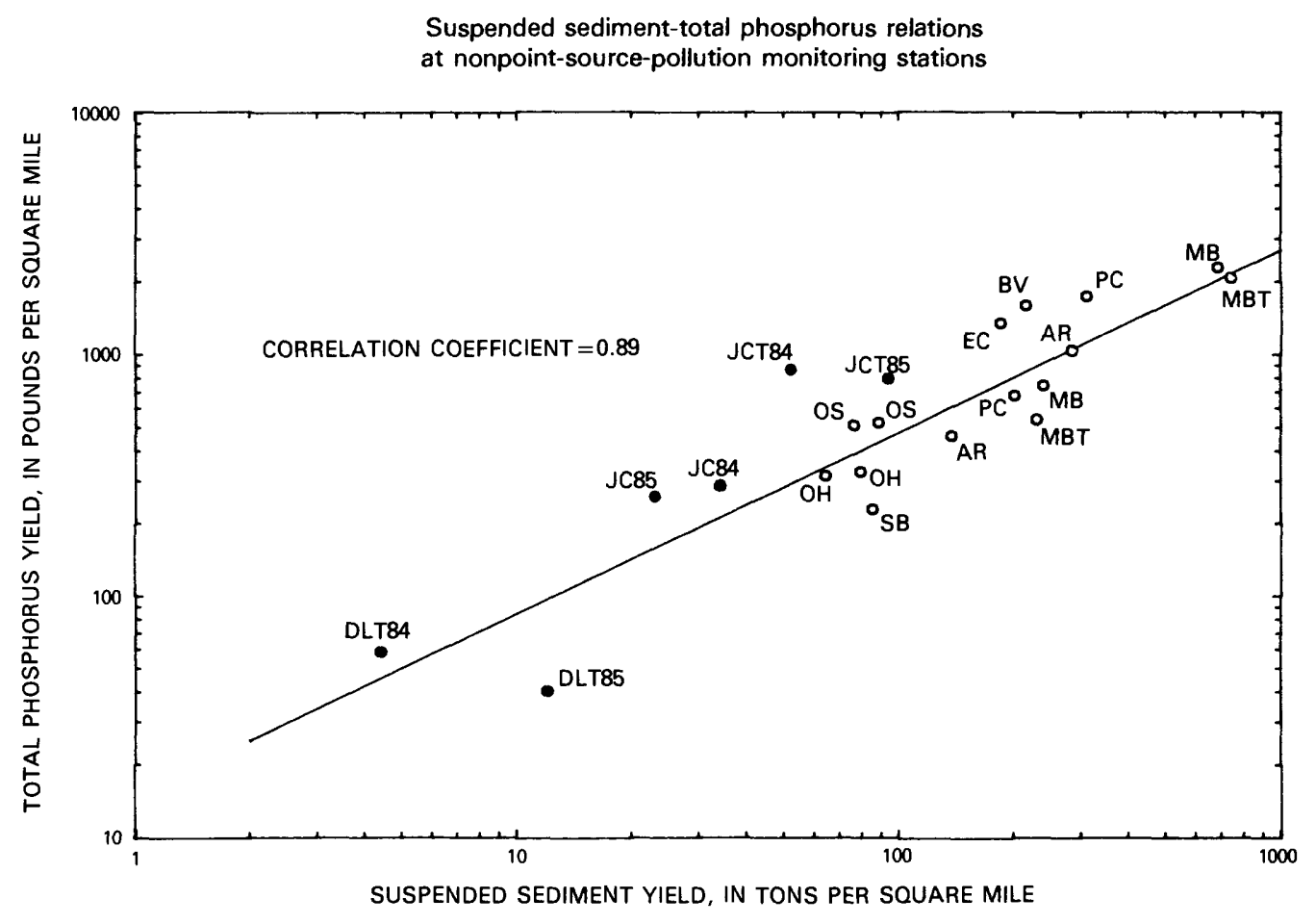

EXPLANATION

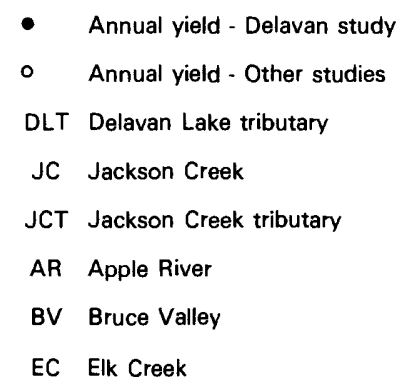

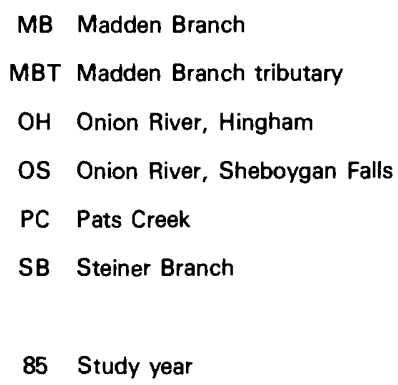

Figure 24. Suspended sediment-total phosphorus relations at nonpoint-source-pollution monitoring stations.

upstream. Estimated discharges at this site may have increased the error in load calculations (see section "Data Collection and Methods of Analysis-Streamflow'). Also, phosphorus sedimentation during surface runoff occurring in the 1.7-mi long, ponded Delavan Lake inlet upstream of State Highway 50 would have reduced the yields from those upstream. Maximum observed total phosphorus concentration during storm runoff at this site was $3.8 \mathrm{mg} / \mathrm{L}$. Minimum total phosphorus concentrations during low-flow periods were very high; they ranged from 0.08 to $0.86 \mathrm{mg} / \mathrm{L}$; the median was $0.29 \mathrm{mg} / \mathrm{L}$. Dissolved orthophosphate phosphorus ranged from 0.01 to $0.18 \mathrm{mg} / \mathrm{L}$ and the median was $0.05 \mathrm{mg} / \mathrm{L}$. These high total phosphorus concentrations during low-flow periods were probably caused by resuspension of the bottom particulate material by carp and bigmouthed buffalo activity in this shallow inlet.

Nitrate nitrogen and Kjeldahl nitrogen yields in the inlet differed significantly from those yields of the basin upstream. Dense algal populations in the ponded inlet assimilate the nitrate nitrogen and ammonia nitrogen and convert it to organic nitrogen.
Suspended-sediment yields were less than those yields from upstream because sedimentation occurs in the ponded inlet.

Considerable short circuiting of the total phosphorus inflow from Delavan Lake inlet may occur considering the proximity of the outlet to Delavan Lake inlet, through which 75 percent of the external total phosphorus input flows. Short circuiting has been demonstrated on other lakes where the outlet is also in close proximity to the inlet (Englert and Stewart, 1983). The total phosphorus output in figure 15 closely follows the total phosphorus input and generally the in-lake total phosphorus mass responds only slightly to external phosphorus inputs (see March 13, June 6, and November 20, 1984, data points). K. L. MacKinnon (Delavan Lake Sanitary District, oral commun., 1985) has also noted that during storm-runoff periods that a line of turbid dark brown water extends from Delavan Lake inlet along the north shore of the lake to the outlet. Figure 25 also illustrates this short circuiting. The peak temporal concentration patterns at both stations are similar although the concentrations of total phosphorus are reduced at the outlet. 
Table 15. Statistical summaries of nutrient and suspended-sediment concentrations in runoff at the four Delavan Lake inflow gaging stations

[Concentrations in milligrams per liter]

\begin{tabular}{|c|c|c|c|c|c|c|}
\hline $\begin{array}{l}\text { Water-quality } \\
\text { characteristic }\end{array}$ & $\begin{array}{c}\text { Number of } \\
\text { samples }\end{array}$ & Maximum & Minimum & Median & Mean & $\begin{array}{l}\text { Standard } \\
\text { deviation }\end{array}$ \\
\hline
\end{tabular}

JACKSON CREEK TRIBUTARY

1984 water year

$\begin{array}{ll}\text { Total phosphorus } & 138 \\ \text { Nitrite + nitrate } & \\ \quad \text { nitrogen } & 132 \\ \text { Kjeldahl nitrogen } & 132 \\ \text { Suspended sediment } & 246 \\ & \\ & \\ \text { Total phosphorus } & 128 \\ \text { Nitrite + nitrate } & \\ \quad \text { nitrogen } & 128 \\ \text { Kjeldahl nitrogen } & 128 \\ \text { Suspended sediment } & 273\end{array}$

$\begin{array}{rcccc}8.2 & <0.01 & 0.77 & 1.1 & 1.3 \\ 13 & .10 & 3.2 & 3.4 & 2.2 \\ 37 & .40 & 2.6 & 3.5 & 3.8 \\ 5,520 & 1 & 84 & 274 & 618\end{array}$

1985 water year

$\begin{array}{rrrrr}4.1 & .20 & .66 & .86 & .66 \\ 6.1 & .50 & 2.7 & 2.8 & 1.3 \\ 13 & .70 & 2.5 & 3.0 & 2.0 \\ 2.456 & 4 & 111 & 229 & 320\end{array}$

JACKSON CREEK

1984 water year

$\begin{array}{lr}\text { Total phosphorus } & 97 \\ \text { Nitrite + nitrate } & \\ \quad \text { nitrogen } & 97 \\ \text { Kjeldahl nitrogen } & 97 \\ \text { Suspended sediment } & 155\end{array}$

$\begin{array}{cc}1.4 & .04 \\ 17 & .05 \\ 5.6 & .40 \\ 802 & 1\end{array}$

$\begin{array}{rrr}.31 & .34 & .22 \\ 5.3 & 5.7 & 3.3 \\ 1.7 & 1.9 & 1.1 \\ 36 & 80 & 124\end{array}$

1985 water year

$\begin{array}{lr}\text { Total phosphorus } & 85 \\ \text { Nitrite }+ \text { nitrate } & \\ \quad \text { nitrogen } & 85 \\ \text { Kjeldahl nitrogen } & 85 \\ \text { Suspended sediment } & 181\end{array}$

$\begin{array}{ccccc}1.1 & .05 & .44 & .46 & .21 \\ 14 & .50 & 5.0 & 5.4 & 2.3 \\ 9.4 & .80 & 1.8 & 2.0 & 1.2 \\ 449 & 5 & 52 & 85 & 85\end{array}$

Delavan Lake Tributary 2

ground water are low and ground-water discharge to the lake is low. For the 1984 water year, phosphorus load was calculated using a mean concentration of $0.02 \mathrm{mg} / \mathrm{L}$ phosphorus and ground-water discharge of $1,820\left(\mathrm{ft}^{3} / \mathrm{s}\right)-\mathrm{d}$ (cubic feet per second days); values of $0.02 \mathrm{mg} / \mathrm{L}$ phosphorus and 2,884 ( $\left.\mathrm{ft}^{3} / \mathrm{s}\right)$-d discharge were used for water year 1985 . The same ground-water discharges were used to calculate the Kjeldahl nitrogen loads. A mean concentration of 0.63 $\mathrm{mg} / \mathrm{L}$ in the 1984 water year was used and $0.84 \mathrm{mg} / \mathrm{L}$ in the 1985 water year was used.

Nitrite plus nitrate concentrations are high in ground water compared to those concentrations found in surface runoff; nitrite plus nitrate loads from ground water therefore contribute significantly to total nitrite plus nitrate nitrogen input to Delavan Lake. A mean concentration of $2.4 \mathrm{mg} / \mathrm{L}$ was used in the 1984 water year to calculate the ground-water load from nitrite plus nitrate nitrogen; in the 1985 water year a mean concentration of $2.6 \mathrm{mg} / \mathrm{L}$ was used. total phosphorus and Kjeldahl nitrogen concentrations in 
Table 15. Statistical summaries of nutrient and suspended-sediment concentrations in runoff at the four Delavan Lake inflow gaging stations-Continued

[Concentrations in milligrams per liter]

\begin{tabular}{|c|c|c|c|c|c|c|}
\hline $\begin{array}{l}\text { Water-quality } \\
\text { characteristic }\end{array}$ & $\begin{array}{c}\text { Number of } \\
\text { samples }\end{array}$ & Maximum & Minimum & Median & Mean & $\begin{array}{l}\text { Standard } \\
\text { deviation }\end{array}$ \\
\hline
\end{tabular}

DELAVAN LAAKE INLET

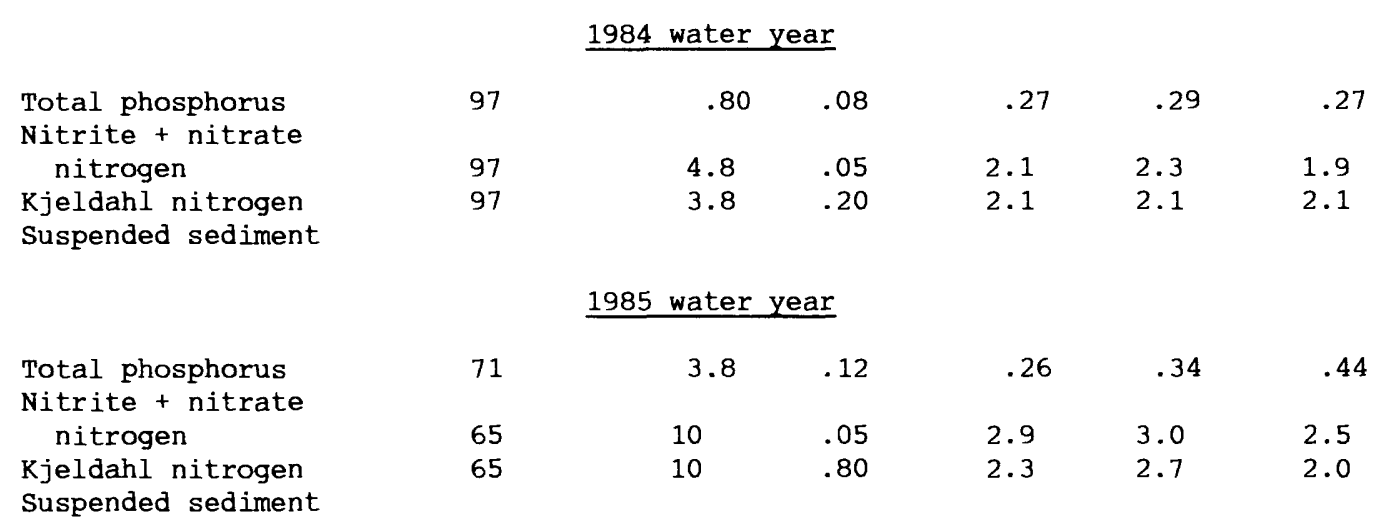

DELAVAN LAKE TRIBUTARY

1984 water year

Total phosphorus
Nitrite + nitrate
nitrogen
Kjeldahl nitrogen
Suspended sedimen

Total phosphorus

Nitrite + nitrate nitrogen

Kjeldahl nitrogen

Suspended sediment

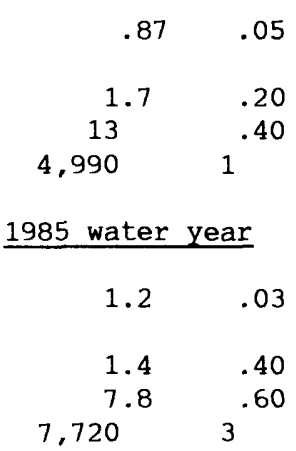

$\begin{array}{ccc}.21 & .27 & .21 \\ .85 & .93 & .46 \\ 1.4 & 2.2 & 2.3 \\ 22 & 225 & 778\end{array}$

22

.30
$1^{.80}$
84

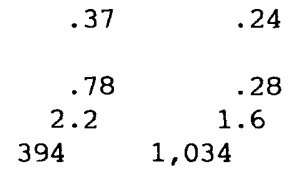

\section{PRECIPITATION}

Concentrations of nutrients in precipitation are low and therefore they account for only a minor part of the external nutrient input to the lake. Data collected during the 1985 water year in the bulk precipitation collector at the DLSD show that total phosphorus concentrations ranged between $<0.01$ and $0.06 \mathrm{mg} / \mathrm{L}$, nitrite plus nitrate nitrogen concentrations ranged from $<0.10$ to $0.70 \mathrm{mg} / \mathrm{L}$, and Kjeldahl nitrogen ranged from 0.10 to $1.3 \mathrm{mg} / \mathrm{L}$.

\section{Nutrient Budget}

A nutrient budget for Delavan Lake for phosphorus and nitrogen, 1984 and 1985 water years, is shown in table 16. For the 2-year average, most of the phosphorus load (75 percent), nitrite plus nitrate nitrogen load (58 percent), and Kjeldahl nitrogen load (62 percent) entered Delavan Lake through Delavan Lake inlet via Jackson Creek. Phosphorus retention in the lake is small; the 1984 water year showed a phosphorus retention of 8 percent of the incoming load and the 1985 water year showed a phosphorus retention of 20 percent. In contrast nitrite plus nitrate nitrogen loads discharging from the lake in both water years showed a 74 percent reduction from the total input; much of this reduction is due to nitrate nitrogen assimilation by the algal cells. Kjeldahl nitrogen loads show only a slight reduction from the incoming load.

\section{Trophic Condition}

The trophic status of Delavan Lake was evaluated by the application of two commonly used methods: Carlson's Trophic State Index and the Vollenweider model. Carlson's Trophic State Index evaluates the in-lake conditions and Vollenweider's model evaluates the nitrogen and phosphorus loadings to a lake. 
Total phosphorus concentrations at

Delavan Lake inlet and outlet

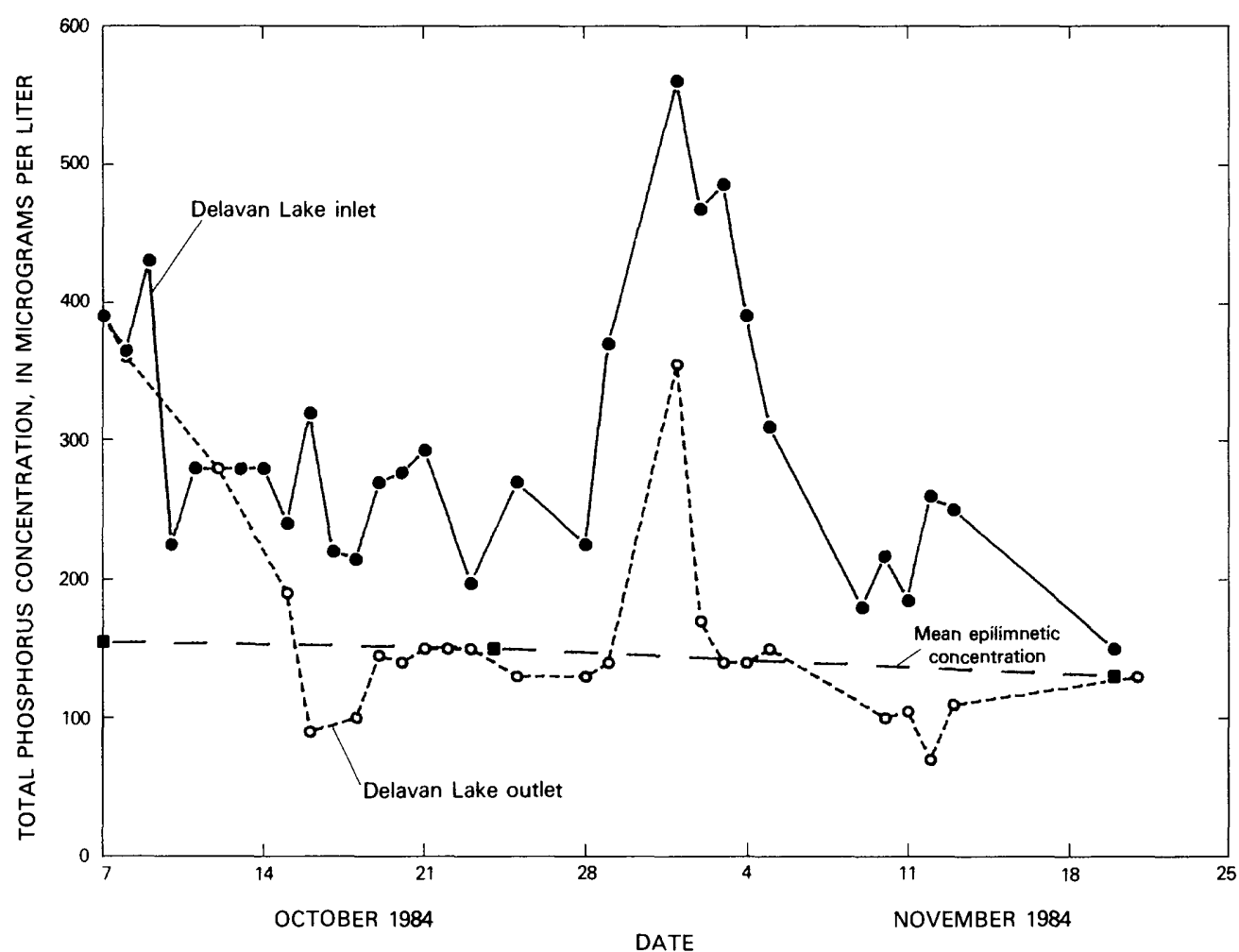

Figure 25. Total phosphorus concentrations at Delavan Lake inlet and outlet.

Trophic-state indices

1984 and 1985 Water Years

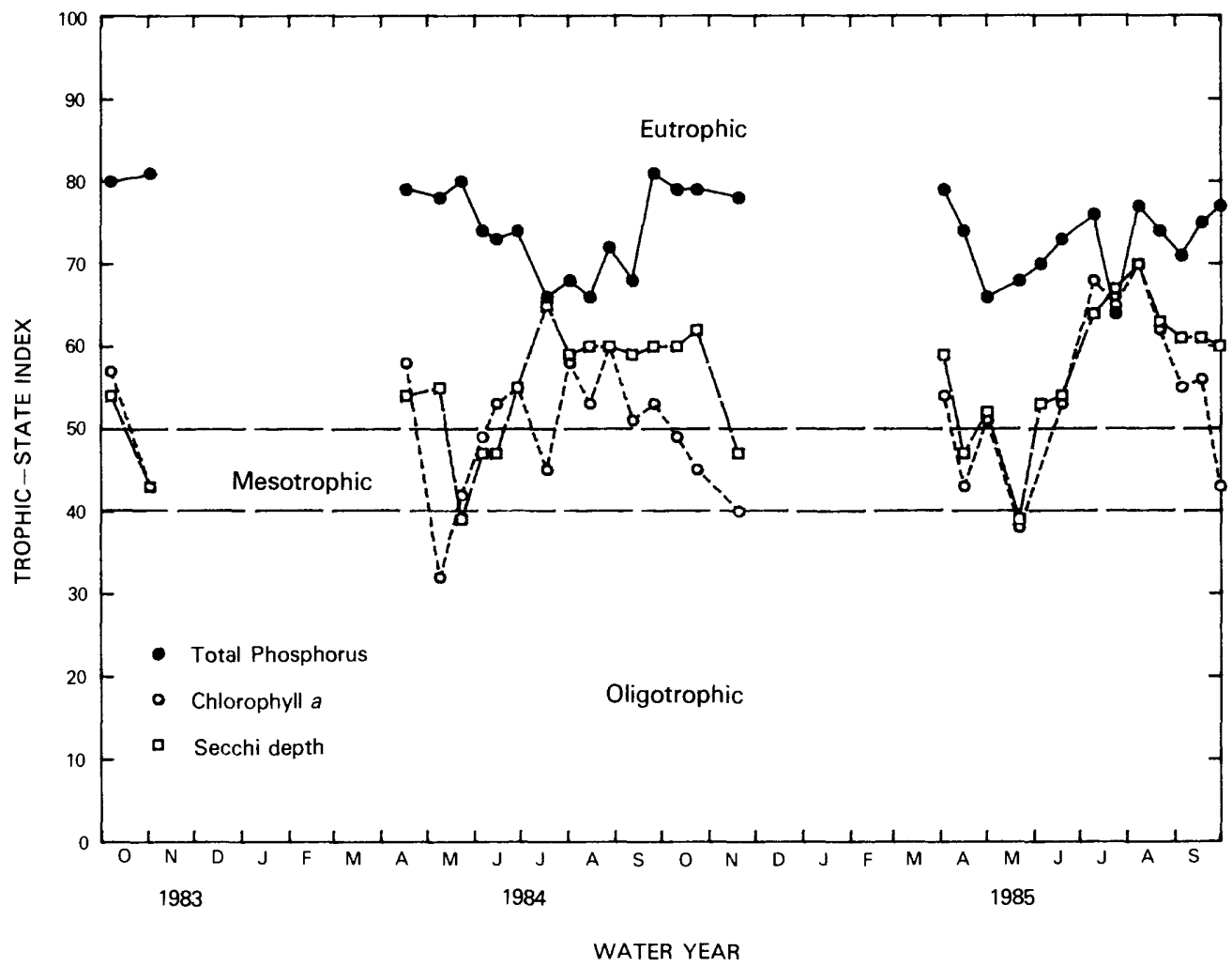

Figure 26. Trophic-state indices, 1984 and 1985 water years. 
Table 16. Annual phosphorus and nitrogen budget for Delavan Lake, 1984 and 1985 water years

[lbs, pounds]

\begin{tabular}{|c|c|c|c|c|c|c|}
\hline & \multicolumn{2}{|c|}{ Phosphorus } & \multicolumn{2}{|c|}{$\begin{array}{c}\text { Nitrite }+ \\
\text { nitrate nitrogen }\end{array}$} & \multicolumn{2}{|c|}{ Kjeldahl nitrogen } \\
\hline & $\begin{array}{l}\text { Amount } \\
\text { (lbs) }\end{array}$ & $\begin{array}{c}\text { Total } \\
\text { input } \\
\text { (percent) }\end{array}$ & $\begin{array}{r}\text { Amount } \\
\text { (lbs) }\end{array}$ & $\begin{array}{c}\text { Total } \\
\text { input } \\
\text { (percent) }\end{array}$ & $\begin{array}{l}\text { Amount } \\
\text { (lbs) }\end{array}$ & $\begin{array}{c}\text { Total } \\
\text { input } \\
\text { (percent) }\end{array}$ \\
\hline \multicolumn{7}{|c|}{1984 water rear } \\
\hline Inputs & & & & & & \\
\hline $\begin{array}{l}\text { Delavan Lake inlet } \\
\text { Delavan Lake }\end{array}$ & 7,040 & 75 & 64,300 & 59 & 57,500 & 66 \\
\hline $\begin{array}{l}\text { tributary } 1 \\
\text { Delavan Lake }\end{array}$ & 309 & 3 & 6,760 & 6 & 1,460 & 2 \\
\hline tributary 2 & 591 & 6 & 3,810 & 3 & 5,220 & 6 \\
\hline $\begin{array}{l}\text { Delavan Lake } \\
\text { drainage shoreline }\end{array}$ & 1,160 & 12 & 3,930 & 4 & 8,180 & 9 \\
\hline $\begin{array}{l}\text { Delavan Lake } \\
\text { precipitation }\end{array}$ & 207 & 2 & 6,100 & 6 & 8,930 & 10 \\
\hline Ground water & 197 & 2 & 23,600 & $\underline{22}$ & $\underline{6,200}$ & 7 \\
\hline TOTAL & 9,500 & 100 & 109,000 & 100 & 87,500 & 100 \\
\hline outputs & & & & & & \\
\hline $\begin{array}{l}\text { Outlet } \\
\text { Total inputs }\end{array}$ & 8,780 & & 28,500 & & 87,900 & \\
\hline - total outputs & 720 & & 80,500 & & -400 & \\
\hline TOTAL & 9,500 & & 109,000 & & 87,500 & \\
\hline
\end{tabular}

1985 water year

Inputs

\begin{tabular}{|c|c|c|c|c|c|c|}
\hline $\begin{array}{l}\text { Delavan Lake inlet } \\
\text { Delavan Lake }\end{array}$ & \multicolumn{2}{|c|}{ Delavan Lake } & & 58 & 45,500 & 57 \\
\hline tributary 1 & 279 & 3 & 6,150 & 4 & 1,260 & 1 \\
\hline \multicolumn{7}{|l|}{ Delavan Lake } \\
\hline tributary 2 & 407 & 5 & 4,120 & 3 & 3,210 & 4 \\
\hline \multicolumn{7}{|l|}{ Delavan Lake } \\
\hline \multicolumn{7}{|l|}{ Delavan Lake } \\
\hline precipitation & 243 & 3 & 7,340 & 5 & 10,100 & 13 \\
\hline Ground water & 311 & $\underline{3}$ & 40,500 & $\underline{27}$ & $\underline{13,100}$ & 16 \\
\hline TOTAL & 8,980 & 100 & 147,000 & 100 & 80,100 & 100 \\
\hline \multicolumn{7}{|l|}{ Outputs } \\
\hline Outlet ${ }^{1}$ & 7,160 & & 38,300 & & 70,700 & \\
\hline \multicolumn{7}{|l|}{ Total inputs } \\
\hline - total outputs & $\underline{1,820}$ & & $\underline{109,000}$ & & 9,400 & \\
\hline TOTAL & 8,980 & & 147,000 & & 80,100 & \\
\hline
\end{tabular}

${ }^{1}$ Corrected for below-dam drainage area. 


\section{CARLSON'S TROPHIC-STATE INDEX}

The in-lake trophic condition can be evaluated by using Carlson's Trophic State Index (TSI) (Carlson, 1977). The TSI is computed using total phosphorus and chlorophyll $a$ concentrations, and Secchi disc transparency readings. Carlson's TSI ranged from 0 for unproductive lakes to 100 for very productive lakes. Carlson, however, did not label ranges of his index in terms of traditional trophic-state terminology. The DNR has used a TSI of 40 to 50 to define mesotrophy, $<40$ to define oligotrophy, and $>50$ to define eutrophy (Wisconsin Department of Natural Resources, 1981 and 1983) in evaluating the trophic status of Wisconsin lakes. G.C. Gerloff (University of Wisconsin, written commun., 1984) also uses these boundaries. These boundaries are used in this report to remain consistent with other Wisconsin lake trophic-state evaluations by the DNR.

The water quality of these three categories varies considerably. The waters of oligotrophic lakes are clear, algal populations are low, and the deepest layers are likely supplied with oxygen throughout the year. Mesotrophic lakes have a moderate supply of nutrients and experience moderate algal blooms and occasional oxygen depletions. Eutrophic lakes are nutrient-rich lakes that experience many waterquality problems such as dense algal blooms and oxygen depletion in parts of the lakes during various seasons; fish kills may result at times if severe oxygen depletions occur.

The following equations were utilized to calculate the TSI for Delavan Lake:

$$
\text { TSI }(\text { Secchi })=60-33.2(\log \text { Secchi depth })
$$

TSI (chlorophyll $a=33.60+17.64$ (log chlorophyll $a$ concentration)

$$
\text { TSI (total phosphorus) }=60-33.2 \log \frac{40.5}{\begin{array}{c}
\text { total phosphorus } \\
\text { concentration }
\end{array}}
$$

Values for above are:

Secchi depth in meters

Chlorophyll $\boldsymbol{a}$ and total phosphorus concentrations in micrograms per liter (values sampled at a 3-ft depth).

The TSI equation for Secchi depth was developed by Carlson (1977) whereas those for chlorophyl $\boldsymbol{a}$ and total phosphorus were developed by the DNR (R. Martin, Wisconsin Department of Natural Resources, oral commun., 1985).

The calculated Trophic State Indices for Delavan Lake are well into the eutrophic scale and are shown in figure 26; only values for open-water periods are shown. The illustration shows that total phosphorus is much higher than the TSI calculations for chlorophyll $a$ and Secchi disc depth. This is expected during spring and fall periods when algal populations are low but not during summer periods. Therefore, the data suggest that phosphorus is at most times not the limiting nutrient and that there is more phosphorus in the lake than the algal cells can utilize.

\section{VOLLENWEIDER'S MODEL}

Total nitrogen and total phosphorus loads to Delavan Lake can be evaluated by comparing these values to those of Vollenweider's model $(1971,1975)$ for predicting critical levels of total nitrogen and total phosphorus loadings to lakes. The total nitrogen and total phosphorus loading to Delavan Lake for the 1984 and 1985 water years using Vollenweider's classification are shown in figure 27.

Vollenweider's "dangerous" rate is the rate at which the receiving waters would become eutrophic (nutrient rich) or remain eutrophic. Vollenweider's model for total nitrogen is based on mean lake depth and total nitrogen loading per unit of lake-surface area. Total nitrogen loading rates for Delavan Lake, based on a mean depth of $25 \mathrm{ft}(7.6 \mathrm{~m})$, are those greater than $0.00053 \mathrm{lbs} / \mathrm{ft}^{2} / \mathrm{yr}\left(2.6\left(\mathrm{~g} / \mathrm{m}^{2}\right) / \mathrm{yr}\right.$ ) (grams per square meter per year). A total nitrogen loading rate of $0.00251 \mathrm{lbs} / \mathrm{ft}^{2} / \mathrm{yr}\left(12.3\left(\mathrm{~g} / \mathrm{m}^{2}\right) / \mathrm{yr}\right)$ was calculated using Vollenweider's model, based on the 1984 water year total nitrogen load of $196,000 \mathrm{lb}$. A loading rate of 0.00292 $\mathrm{lbs} / \mathrm{ft}^{2} / \mathrm{yr}\left(14.3\left(\mathrm{~g} / \mathrm{m}^{2}\right) / \mathrm{yr}\right)$ was calculated in the 1985 water year based on the total nitrogen load of 228,000 lb. Total nitrogen loading for both years falls in the "dangerous" category classified by Vollenweider.

Vollenweider's model for evaluating total phosphorus loading to a lake is based on mean lake depth/hydraulic residence time and loading per unit of lake-surface area. Based on the 1984 water year hydraulic residence time of 2.2 years, the total phosphorus dangerous rates are those greater than $0.0000754\left(\mathrm{lb} / \mathrm{ft}^{2}\right) / \mathrm{yr}\left[0.37\left(\mathrm{~g} / \mathrm{m}^{2}\right) / \mathrm{yr}\right]$; using the total phosphorus external load of $9,500 \mathrm{lb}^{7}$, a phosphorus loading rate of $0.000121\left(\mathrm{lb} / \mathrm{ft}^{2}\right) / \mathrm{yr}\left[0.59\left(\mathrm{~g} / \mathrm{m}^{2}\right) / \mathrm{yr}\right]$ was calculated. Based on the 1985 water year hydraulic residence time of 1.8 years, the total phosphorus dangerous rates are those greater than $0.0000836\left(\mathrm{lb} / \mathrm{ft}^{2}\right) / \mathrm{yr}\left[0.41\left(\mathrm{~g} / \mathrm{m}^{2}\right) / \mathrm{yr}\right]$; using the total phosphorus external load of $8,980 \mathrm{lb}$, a phosphorus loading rate of $0.000114\left(\mathrm{lb} / \mathrm{ft}^{2}\right) / \mathrm{yr}[0.56$ $\left.\left(\mathrm{g} / \mathrm{m}^{2}\right) / \mathrm{yr}\right]$ was calculated. Total phosphorus external loading for both years falls into the "dangerous" classification by Vollenweider. Vollenweider's classification does not include internal loading.

\section{Internal Loading}

The internal phosphorus supply (phosphorus released from the sediments) can contribute up to 91 percent of total phosphorus input (external and internal load) to a lake

${ }^{7}$ These loads are significantly reduced from these prior to sewage diversion. The total phosphorus contribution in 1972 (U.S. Environmental Protection Agency, 1974) from sewage-treatment plants alone was estimated at 13,400 lb; EPA's total phosphorus estimated load to the lake was 17,600 $\mathrm{lb}$ and using Vollenweider's model produced a loading rate of 0.0002296 $\left(\mathrm{lb} / \mathrm{ft}^{2}\right) / \mathrm{yr}\left[1.12\left(\mathrm{~g} / \mathrm{m}^{2}\right) / \mathrm{yr}\right]$. 
Phophorus loading per unit of lake surface versus mean lake depth/hydraulic residence time

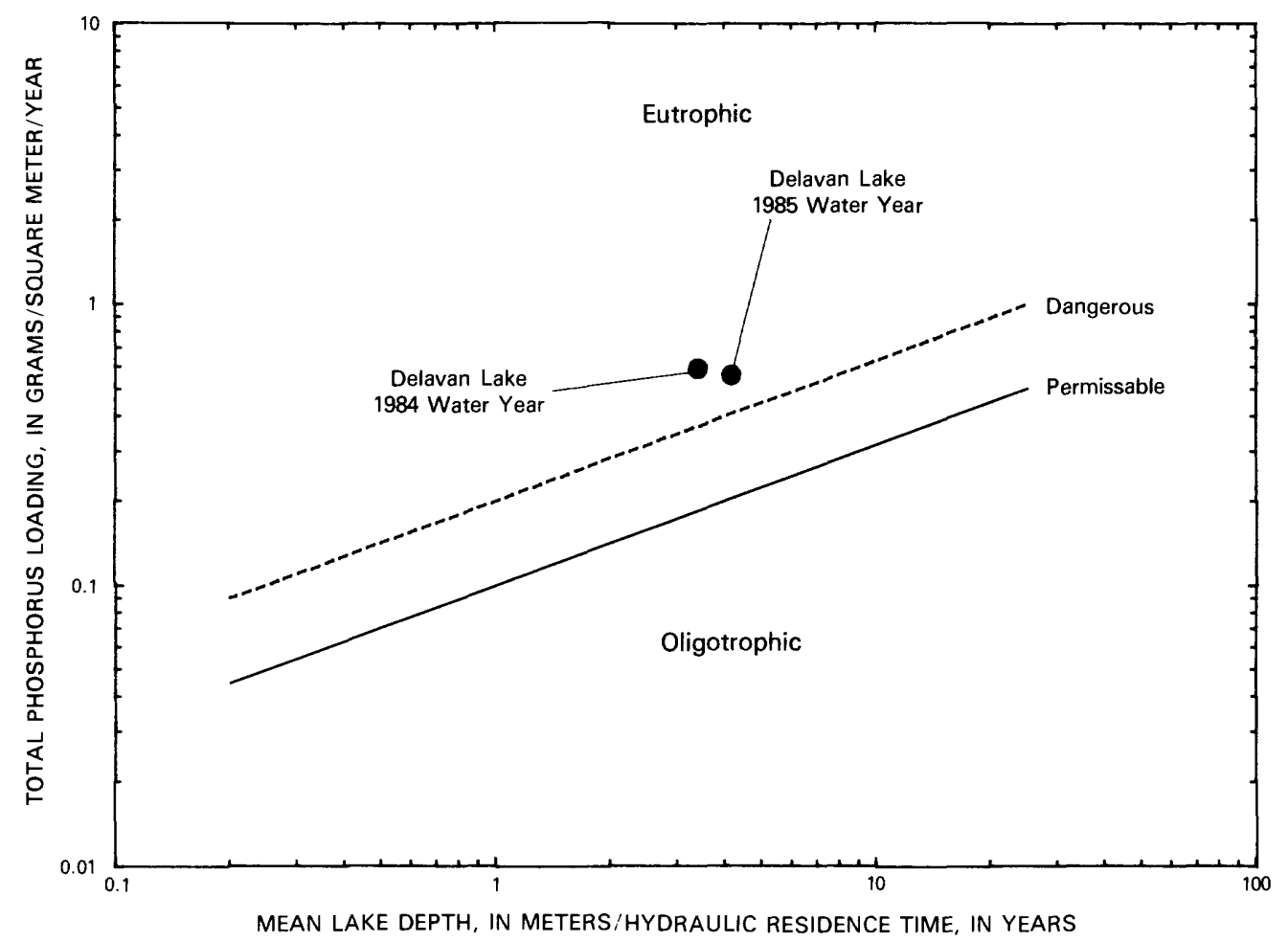

Nitrogen loading per unit of lake surface versus mean lake depth

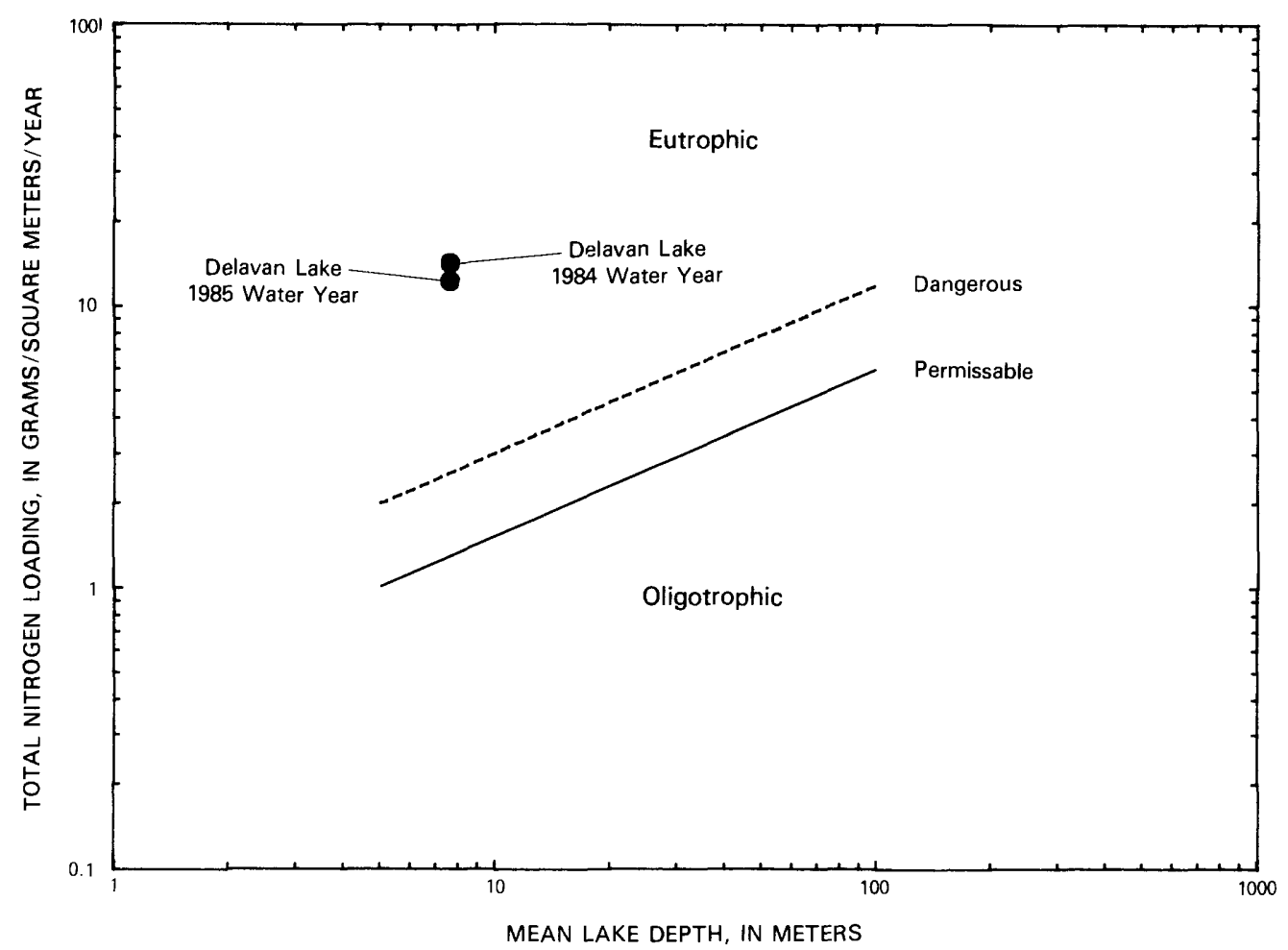

Figure 27. Nitrogen- and phosphorus-loading classifications for Delavan Lake (Vollenweider model). 
(Bengtsson, 1978). Nurnberg and Peters (1984) found that for 23 stratified lakes with anoxic hypolimnia, the internal supply contributed an average of 39 percent to the total phosphorus load. They also found in lakes with a long history of high external phosphorus loading the sediments released phosphorus into the anoxic hypolimnia when the external load was reduced. Therefore, these lakes did not respond quickly to external nutrient diversion. The phosphorus release from the Delavan Lake sediments during anoxic periods has been discussed previously in the "Phosphorus" section of this report.

Internal loading to Delavan Lake was calculated using a mass-balance phosphorus budget according to the following equation:

Net gain or loss $=$ change of total phosphorus (TP) in lake + outflow TP mass - inflow TP mass

An increase was considered evidence for internal phosphorus loading, a decrease for sedimentation. A summary of the external input, output, changes in the water column and internal loading/sedimentation are shown in tables 17-18. The data are expressed graphically in figure 15 .

Internal loading of phosphorus during both water years exceeded the external loading by more than two times. Internal loading of phosphorus in the 1984 water year was determined to be $23,600 \mathrm{lb}$, and $26,200 \mathrm{lb}$ for sedimentation. The annual net deposition to the sediments was 2,600 lb. Internal loading of phosphorus in the 1985 water year declined to $19,500 \mathrm{lb}$ from that determined in the 1984 water year. More phosphorus in the 1985 water year was also lost to the sediments, $25,000 \mathrm{lb}$, for a net loss or deposition of phosphorus to the sediments of $5,500 \mathrm{lb}$. Net loss of total phosphorus to the sediments for the 2-year period was $8,100 \mathrm{lb}$.

The phosphorus release rate for the 1984 water year was calculated for the anoxic period, June 10 to September 20, by adding the net gains and dividing by the number of days from June 7 to September 26. This amounted to a release rate of $155 \mathrm{lb} / \mathrm{d}$ [70.3 kg/d (kilogram per day)]. When these figures were extrapolated to the weighted mean area of the anoxic bottom sediments $\left(2.70 \times 10^{7} \mathrm{ft}^{2}\right)\left(2.51 \times 10^{6} \mathrm{~m}^{2}\right)$ the average release rate was $0.574 \times 10^{-5}\left(\mathrm{lb} / \mathrm{ft}^{2}\right) / \mathrm{d}[(28$ $\mathrm{mg} / \mathrm{m}^{2}$ )/d (milligrams per square meter per day)]. The phosphorus release rate for the 1985 water year was calculated for the anoxic period, June 25 to September 14, by adding the net gains and dividing by the number of days from June 20 to September 18. This amounted to a release rate of $95 \mathrm{lb} / \mathrm{d}(43.1 \mathrm{~kg} / \mathrm{d})$. When these figures were extrapolated to the weighted mean area of the anoxic bottom sediments $2.84 \times 10^{7} \mathrm{ft}^{2}\left(2.64 \times 10^{6} \mathrm{~m}^{2}\right)$ the average release rate was $0.328 \times 10^{-5}\left(\mathrm{lb} / \mathrm{ft}^{2}\right) / \mathrm{d}\left[\left(16 \mathrm{mg} / \mathrm{m}^{2}\right) / \mathrm{d}\right]$. These release rates are high when compared to the anoxic lake release rates compiled by Nurnberg (1984): Mendota $0.221 \times 10^{-5}(10.8)$, Shagawa $0.248 \times 10^{-5}(12.1)$, White Lake $0.389 \times 10^{-5}$ (19), Bengundasjoen $0.502 \times 10^{-5}$
(24.5), Rotsee $0.574 \times 10^{-5}(28)$. All units are in pounds per square foot per day (milligrams per square meter per day). Rotsee had the highest release rate of the 15 anoxic lakes compiled by Nurnberg. In comparison of the Delavan Lake release rates to that of Lake Mendota, the release rates do not appear excessively high considering the phosphorus accumulation rates due to anoxic release above the bottom sediments for Delavan Lake are almost twice those in Lake Mendota (see section on "Phosphorus").

\section{ASSESSMENT OF LAKE CONDITION}

The water-quality goal for Delavan Lake is to reduce phosphorus levels in the lake until phosphorus becomes the limiting nutrient and no longer causes algal problems in the lake. A graph of the phosphorus mass in the lake over time (fig. 28) indicates the trend of the phosphorus mass and whether the lake is improving. An upward trend suggests a worsening condition, a downward trend suggests an improving condition.

The data plotted in the lower graph in figure 28 are the data collected as part of the study and by Stauffer (1974). The data collected by Stauffer show in-lake phosphorus mass as high as $24,800 \mathrm{lb}$. This translates to an average in-lake concentration of $203 \mu \mathrm{g} / \mathrm{L}$, using this phosphorus mass and a lake volume of 44,806 acre- $\mathrm{ft}$. The maximum in-lake mass measured during the present study was $22,400 \mathrm{lb}$ and the average phosphorus concentration was $183 \mu \mathrm{g} / \mathrm{L}$. Stauffer monitored Delavan Lake only from March 12 to October 26, 1972. The maximum in-lake phosphorus mass measured in the 1984 water year was on January 17. Therefore, Stauffer may not have observed the maximum in-lake mass for the water year and it may have been higher than he documented. Stauffer collected the data 9 years prior to sewage diversion and at the time of sewage diversion the phosphorus mass in the lake was likely greater than the present study or Stauffer's data indicate.

The phosphorus data trend shown in figure 28 indicates a reduction in the in-lake phosphorus mass since the start of the project in October 1983, and thus implies an improving condition. It should be noted, however, that the reduction of phosphorus mass was caused by the reduced internal load in the 1985 water year from 1984 because of a shorter anoxic period. Even though the internal load in the 1985 water year was reduced once anoxia began, the dissolved orthophosphorus accumulation rates for both years were approximately the same. Therefore, a longer anoxic period in future years may result in a reversal of the declining phosphorus trend.

\section{CONCLUSIONS}

A comprehensive 2-year hydrologic and water-quality investigation of Delavan Lake indicated that, despite the 1981 diversion of sewage effluent and septic leachate from Delavan Lake, large amounts of phosphorus in the bottom sediments 
Table 17. Summary of total phosphorus (TP) input, output, and changes in the water column, Delavan Lake, 1984 water year

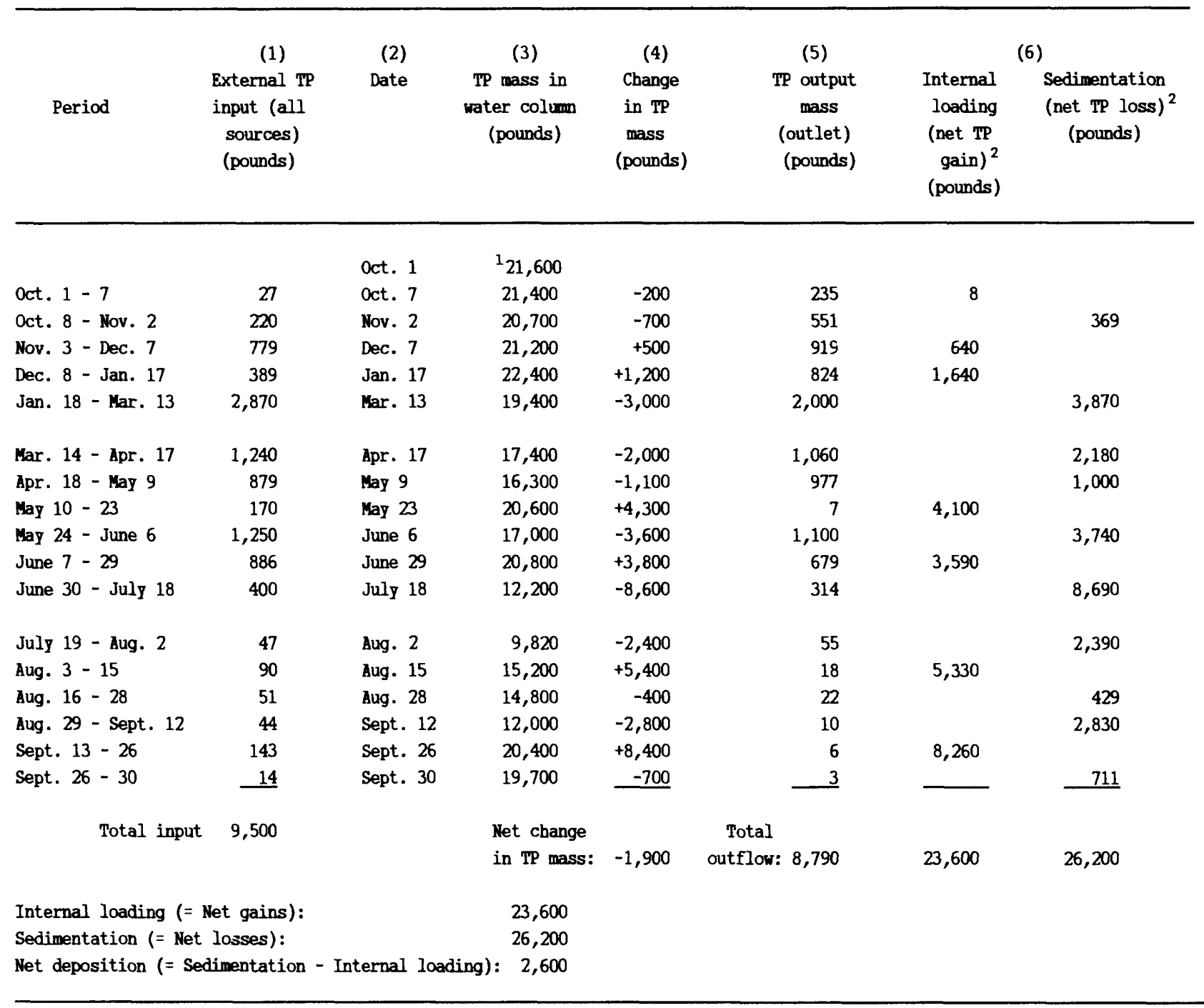

\footnotetext{
${ }^{1}$ Estimated from plot.

${ }^{2}$ Net TP gain or loss = + change in TP mass in lake (4) + outflow TP mass (5) - inflow TP mass (1).
}

are released when anoxic conditions are reached, causing internal loading to exceed external supply by more than two times. The external loading of phosphorus and nitrogen were assessed using Vollenweider's model and the calculated hydraulic residence times of 2.2 years during the 1984 water year and 1.8 years during the 1985 water year. This model indicated that the loadings are excessive and will cause eutrophic conditions.

Continuous streamflow and water-quality monitoring in the subbasins of the Delavan Lake basin showed a wide range of anrual yields of phosphorus and nitrogen. The subbasin of Jackson Creek, which drains mostly the city of Elkhorn, had the greatest average yield of phosphorus $\left(838 \mathrm{lb} / \mathrm{mi}^{2}\right)$ and Kjeldahl nitrogen $\left(3,600 \mathrm{lb} / \mathrm{mi}^{2}\right)$. These yields were almost three times those from the headwaters of Jackson Creek, where the largest concentration of livestock is found. Delavan Lake tributary 2 had an extremely low average an- nual yield of phosphorus $\left(53.1 \mathrm{lb} / \mathrm{mi}^{2}\right)$ and $\mathrm{Kjeldahl}$ nitrogen $\left(550 \mathrm{lb} / \mathrm{mi}^{2}\right)$. This was due to significantly reduced runoff from storage and evapotranspiration in a large wetland surrounding a large pond in the stream's basin. Most of the average annual input of nutrients flow into Delavan Lake through Delavan Lake inlet via Jackson Creek: phosphorus, 75 percent, nitrate nitrogen, 58 percent, and Kjeldahl nitrogen, 62 percent.

Precipitation was near normal, 32.0 in. during the 1984 water year, but was 7.3 in. greater than normal during the 1985 water year. Phosphorus and Kjeldahl nitrogen loads from external sources were smaller despite the greater than normal precipitation in the second year of study.

The water quality of Delavan Lake indicates eutrophic conditions: average in-lake total phosphorus concentration maximum was $184 \mu \mathrm{g} / \mathrm{L}$ on January 17,1984 ; Secchi disc transparency minimum was $1.6 \mathrm{ft}$ on July 10 and August 8 , 
Table 18. Summary of total phosphorus (TP) input, output, and changes in the water column, Delavan Lake, 1985 water year

\begin{tabular}{|c|c|c|c|c|c|c|c|}
\hline Period & $\begin{array}{c}\text { (1) } \\
\text { External TP } \\
\text { input (all } \\
\text { sources) } \\
\text { (pounds) }\end{array}$ & $\begin{array}{r}(2) \\
\text { Date }\end{array}$ & $\begin{array}{c}\text { (3) } \\
\text { TP mass in } \\
\text { water columm } \\
\text { (pounds) }\end{array}$ & $\begin{array}{l}\text { (4) } \\
\text { Change } \\
\text { in TP } \\
\text { mass } \\
\text { (pounds) }\end{array}$ & $\begin{array}{c}\text { (5) } \\
\text { TP output } \\
\text { mass } \\
\text { (outlet) } \\
\text { (pounds) }\end{array}$ & $\begin{array}{c}\text { Internal } \\
\text { loading } \\
\text { (net TP }^{2} \\
\text { gain) } \\
\text { (pounds) }\end{array}$ & $\begin{array}{l}\text { Sedimentation } \\
\text { (net TP loss) }^{2} \\
\text { (pounds) }\end{array}$ \\
\hline & & Oct. 1 & ${ }^{1} 19,700$ & & & & \\
\hline Oct. $1-11$ & 67 & Oct. 11 & 18,100 & $-1,600$ & 69 & & 1,600 \\
\hline Oct. $12-24$ & 419 & Oct. 24 & 18,400 & +300 & 478 & 359 & \\
\hline Oct. 25 - Nov. 20 & 1,660 & Nov. 20 & 17,400 & $-1,000$ & 974 & & 1,690 \\
\hline Nov. 21 - Dec. 18 & 651 & Dec. 18 & 16,000 & $-1,400$ & 623 & & 1,430 \\
\hline Dec. 19 - Jan. 24 & 1,030 & Jan. 24 & 17,100 & $+1,100$ & 1,070 & 1,140 & \\
\hline Jan. 25 - Mar. 6 & 2,060 & Mar. 6 & 13,300 & $-3,800$ & 966 & & 4,890 \\
\hline Mar. 7 - Apr. 3 & 1,000 & Apr. 3 & 16,800 & $+3,500$ & 1,290 & 3,790 & \\
\hline Apr. $4-16$ & 346 & Apr. 16 & 12,300 & $-4,500$ & 517 & & 4,330 \\
\hline Apr. 17 - May 1 & 197 & May 1 & 6,630 & $-5,670$ & 334 & & 5,530 \\
\hline May $2-22$ & 196 & May 22 & 9,610 & $+2,980$ & 4 & 2,790 & \\
\hline May 23 - June 5 & 317 & June 5 & 10,100 & +500 & 2 & 185 & \\
\hline June $6-19$ & 91 & June 19 & 11,500 & $+1,400$ & 4 & 1,310 & \\
\hline June 20 - July 10 & 81 & July 10 & 15,300 & $+3,800$ & 44 & 3,760 & \\
\hline July $11-24$ & 147 & July 24 & 19,500 & $+4,200$ & 135 & 4,190 & \\
\hline July 25 - Aug. 8 & 56 & Aug. 8 & 16,900 & $-2,600$ & 48 & & 2,610 \\
\hline Aug. $9-22$ & 87 & Aug. 22 & 15,700 & $-1,200$ & 137 & & 1,150 \\
\hline Aug. 23 - Sept. 5 & 118 & Sept. 5 & 14,000 & $-1,700$ & 35 & & 1,780 \\
\hline Sept. $6-18$ & 389 & Sept. 18 & 14,700 & +700 & 429 & 740 & \\
\hline Sept. $19-30$ & 66 & Sept. 30 & 16,000 & $\pm 1,300$ & 8 & 1,240 & \\
\hline Total input & 8,980 & & $\begin{array}{l}\text { Net change } \\
\text { in TP mass: }\end{array}$ & $-3,660$ & $\begin{array}{l}\text { Total } \\
\text { outflow: } 7,170\end{array}$ & 19,500 & 25,000 \\
\hline Internal loading $(=N$ & Net gains): & & 19,500 & & & & \\
\hline Sedimentation $(=\mathrm{Net}$ & losses): & & 25,000 & & & & \\
\hline Net deposition $(=\mathrm{Sec}$ & dimentation - & ternal loa & ing): 5,500 & & & & \\
\hline
\end{tabular}

\footnotetext{
${ }^{1}$ Estimated from plot.

${ }^{2}$ Net TP gain or loss $=+$ + change in TP mass in lake (4) + outflow TP mass (5) - inflow TP mass (1).
}

1985; chlorophyll $a$ concentration maximum was $87 \mu \mathrm{g} / \mathrm{L}$ on July 10 . Summer anoxia during the 1984 water year lasted 102 days in 1984 and during the 1985 water year it lasted 81 days. Large amounts of phosphorus are released during summer anoxia into the water column from the bottom sediments, which are high in phosphorus. Dissolved orthophosphorus above the bottom sediments accumulated at a rate of $6.7 \mu \mathrm{g} / \mathrm{L} / \mathrm{d}$ during the 1984 water year; during the 1985 water year it was almost the same $-7.4 \mu \mathrm{g} / \mathrm{L} / \mathrm{d}$.

Nitrogen limitation occurs frequently in the lake and blue-green algae dominate the summer algal population. Blue-green algae composed 98,95 , and 84 percent of the total algal population during June, July, and August of 1984; the dominant species was Synechocystis sp. Blue-green algae declined to 45 percent of the total population during June, 76 percent in July, and 71 percent in August of the 1985 water year; Synechocystis sp., Anabena circinalis, and Aphanizomenon flos-aqua were the dominant species.

Twenty-eight species of zooplankton were found in varying degrees of abundance. The zooplankton community peaked during the 1984 water year in September, after the blue-green algal population declined. The zooplankton community peaked during the 1985 water year in July. The dominant zooplankton in middle to late summer is the cladoceran, Chydorus sphaericus.

The benthic community has a small population of macroinvertebrates; the chironomidae are the dominant 
Delavan Lake inlake total

phosphorus mass: 1983-1986

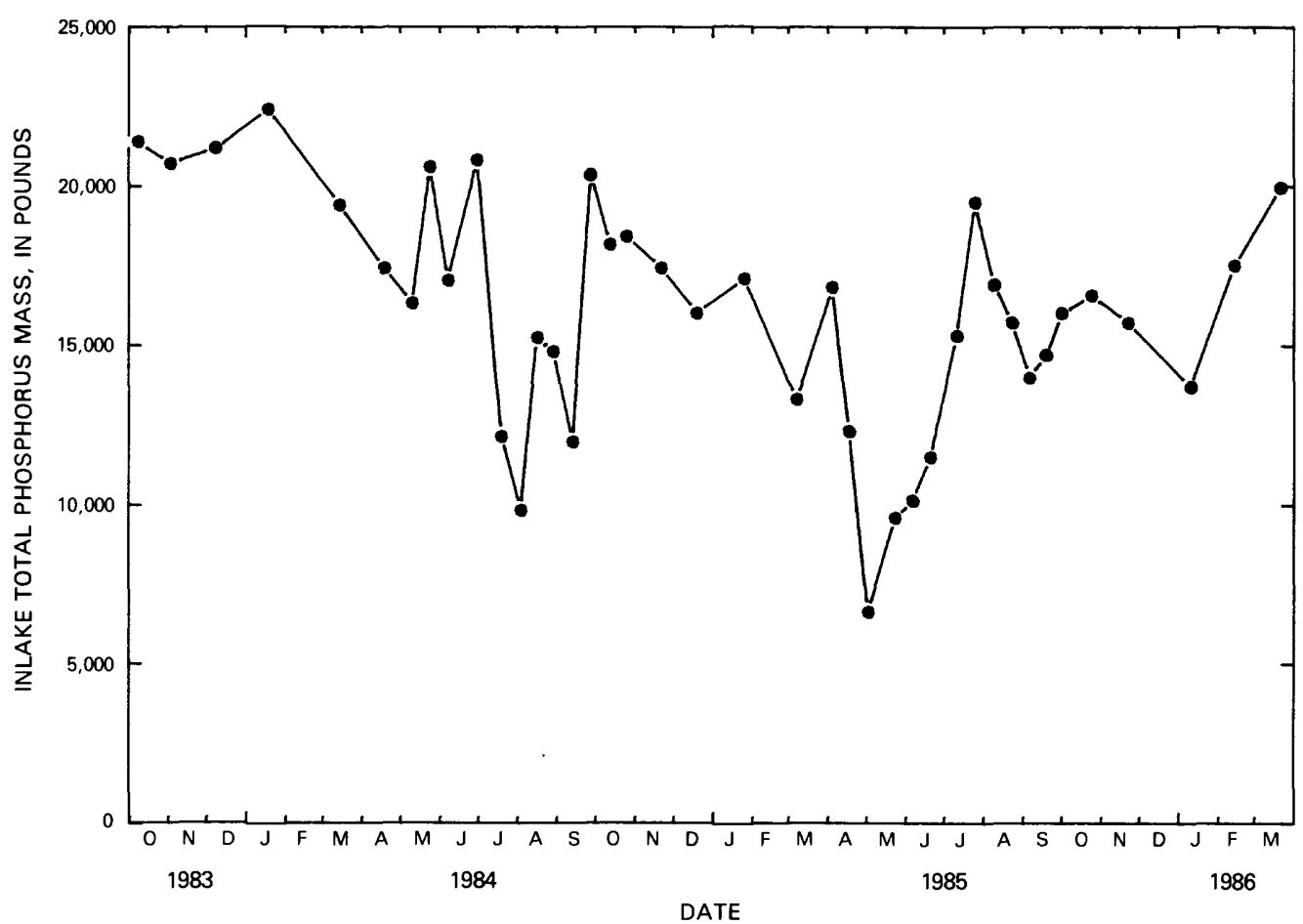

Delavan Lake inlake total phosphorus

mass: 1972 (Stauffer), 1983-1986 (Field)

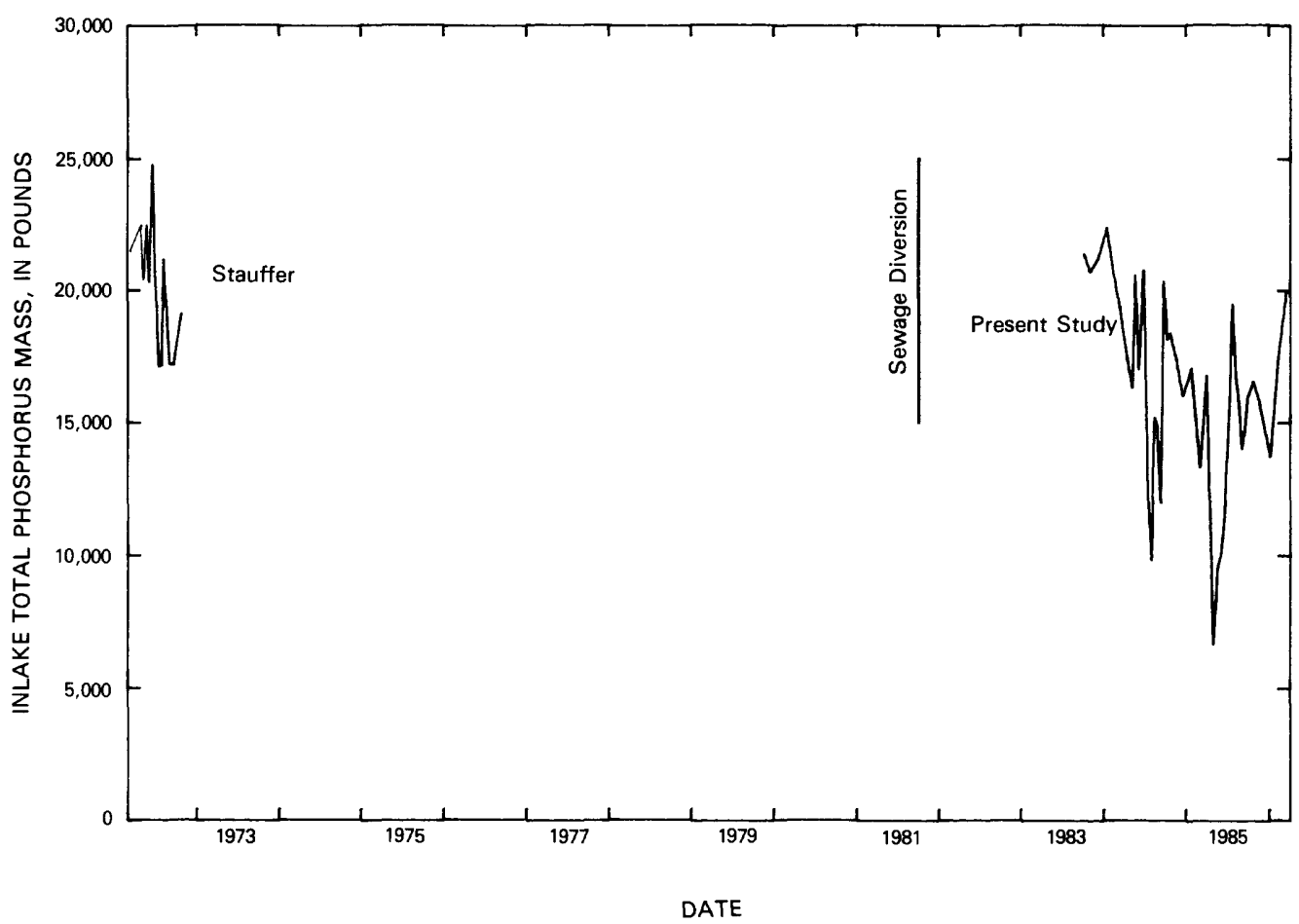

Figure 28. Delavan Lake in-lake phosphorus mass, 1972 and 1983-86. 
group. The average number of organisms of 4 sampling periods at 12 sites was $65.7 / \mathrm{ft}^{2}\left(707 / \mathrm{m}^{2}\right)$.

The trend of in-lake phosphorus mass is in a declining direction and it suggests an improvement in the water quality of Delavan Lake. However, there is generally more phosphorus in the lake than the algae need to flourish; even though the phosphorus mass is becoming less, a visual improvement in the water quality will not be apparent until phosphorus declines below the point that phosphorus becomes limiting.

The Delavan Lake tributary 2 basin has a large valuable wetland that should be protected from destruction. This wetland reduces storm runoff from this basin by storage and evapotranspiration thereby reducing phosphorus loadings to Delavan Lake.

It is important to maintain a water-quality monitoring program for Delavan Lake and its drainage basin to monitor the phosphorus trend in the lake regardless of the rehabilitation plan chosen. Phosphorus yields in the Jackson Creek tributary basin draining the city of Elkhorn are excessively high: streamflow and phosphorus load monitoring at this gaging station should be continued. Seventy-five percent of the total phosphorus external load flows into Delavan Lake from Jackson Creek through Delavan Lake inlet and therefore this station should also be continued by monitoring streamflow and phosphorus loads. The outlet station at Borg Road should also be continued for monitoring streamflow and phosphorus load. The Delavan Lake tributary 2 gaging station should be operated every 2 to 3 years to insure that runoff characteristics of this valuable basin do not increase. In-lake water-quality monitoring at the same sites as previously monitored for depth profiles of water temperatures, dissolved oxygen, $\mathrm{pH}$, and specific conductance should be continued as well. In-lake samples should also be collected for total phosphorus, dissolved orthophosphate phosphorus, chlorophyll $\boldsymbol{a}$, Secchi depth, phytoplankton, and zooplankton.

\section{REFERENCES}

Bates, R. L., and Jackson, J. A., 1980, Glossary of geology (2d ed.): American Geological Institute, Falls Church, Virginia, $749 \mathrm{p}$.

Bengtsson., L., 1978, Effects of sewage diversion in lake Sondra Bergundasjon 1. Nitrogen and phosphorus budgets: Vatten 1:2-9.

Borman, R. G., 1976, Ground-water resources and geology of Walworth County, Wisconsin: Wisconsin Geological and Natural History Survey Information Circular No. 34,45 p.

Britton, L. J., Averett, R. C., and Ferreira, 1975, An introduction to the processes, problems, and management of urban lakes: U.S. Geological Survey Circular 601-K, $22 \mathrm{p}$.
Carlson, R. E., 1977, A trophic state index for lakes: Limnology and Oceanography, March, v. 22(2), p. 361-369.

Chow, V. T., 1964, Handbook of applied hydrology: New York, p. 17-12.

Cole, G. A., 1979, Textbook of limnology (2d ed.): St. Louis, Mo., $426 \mathrm{p}$.

Conger, D. H., 1981, Techniques for estimating magnitude and frequency of floods for Wisconsin streams: U.S. Geological Survey Water-Resources Investigations Open-File Report 80-1214, 116 p.

Dion, N. P., Bartleson, G. C., McConnell, J. B., and Innes, J. K., 1976, Data on selected lakes in Washington, part 5: Washington State Department of Ecology, 125 p.

Dunne, Thomas, and Leopold, L. B., 1978, Water in environmental planning: W. H. Freeman and Company, San Francisco, $818 \mathrm{p}$.

Elder, J. F., 1985, Nitrogen and phosphorus speciation and flux in a large Florida river wetland system, Water Resources Research, Vol. 21, No. 5, p. 724-732.

Englert, J. P., and Stewart, K. M., 1983, Natural shortcircuiting of inflow to outflow through Silver Lake, New York: Water Resources Research, v. 19, no. 2, April, p. 529-537.

Field, S. J., 1984, An assessment of nonpoint-source discharges, streamflow, and water quality in Onion River, Wisconsin: U.S. Geological Survey WaterResources Investigations Report 84-4066, 78 p. 1985 , Nonpoint-source discharges and water quality of the Elk Creek basin, west-central Wisconsin: U.S. Geological Survey Water-Resources Investigations Report 84-4094, 37 p.

1986, Relationship of nonpoint-source discharges, streamflow, and water quality in the Galena River basin, Wisconsin: U.S. Geological Survey Water-Resources Investigations Report 85-4214, 48 p.

Field, S. J., and Lidwin, R. A., 1982, Water-quality assessment of Steiner Branch basin, Lafayette County, Wisconsin: U.S. Geological Survey Water-Resources Investigations $81-52,58 \mathrm{p}$.

Fishman, M. J., and Friedman, L. C., 1985, Methods for determination of inorganic substances in water and fluvial sediments: U. S. Geological Survey, Open-File report 85-495, $709 \mathrm{p}$.

Guy, P., and Norman, V. W., 1970. Field methods for measurement of fluvial sediment: U.S. Geological Survey Techniques of Water-Resources Investigations, Book 3, Chapter C2, $50 \mathrm{p}$.

Hanson, M. J., 1981, The use of copper sulfate for algal control; copper treatments in the Fairmont Lakes, 1921-1979: Fairmont, Minnesota, Fairmont Lakes Commission Report No. 5.

Hanson, M. J., and Stefan, H. G., 1984, Side effects of 58 years of copper sulfate treatment of the Fairmont Lakes, Minnesota: Water Resources Bulletin, American Water Resources Association, December, p. 889-900. 
Haszel, O. V., 1971, Soil survey, Walworth County, Wisconsin: Soil Conservation Service, U.S. Department of Agriculture, $107 \mathrm{p}$.

Hem, J. D., 1985, Study and interpretation of the chemical characteristics of natural water (3rd ed.): U.S. Geological Survey Water-Supply Paper 2254, 263 p.

Holdren, G. C., and Armstrong, D. E., 1980, Factors affecting phosphorus release from intact lake sediment cores: Environmental Science and Technology 14:79-87.

Holmstrom, B. K., Kammerer, P. A., Jr., and Erickson, R. M., 1985, Water resources data-Wisconsin, water year 1984, U.S. Geological Survey Water-Data Report WI-84-1, $373 \mathrm{p}$.

1986, Water resources data-Wisconsin, water year 1985, U.S. Geological Survey Water-Data Report WI-85-1, 414 p.

Kilham, P., 1971, A hypothesis concerning silica and the freshwater planktonic diatoms: Limnology and Oceanography, v. 16 , no. 1, p. 10-18.

Kerfoot, C. W. (ed.), 1980, Evolution and ecology of zooplankton communities: University Press of New England, American Society of Limnological and Oceanography, Special symposium, v. 3, 793 p.

Kuhn, G., and others, 1983, Hydrology of area 54, Northern Great Plains and Rocky Mountain coal provinces, Colorado and Wyoming: U.S. Geological Survey Open-File Report 83-146, 102 p.

Langbein, W. B., and Iseri, K. T., 1960, General introduction and hydrologic definitions, Manual of hydrology, part 1, General surface-water techniques: U.S. Geological Survey Water-Supply Paper 1541-A, 29 p.

Lillie, R. A., and Mason, J. W., 1983, Limnological characteristics of Wisconsin lakes: Department of Natural Resources Technical Bulletin No. 138, 116 p.

Limnetics Incorporated, 1969, Lake Delavan limnological survey, July 1 through 31 December 1968: Informational paper.

Mortimer, C. H., 1941, The exchange of dissolved substances between mud and water in lakes: Journal of Ecology, v. 29, p. 280-329.

1942, The exchange of dissolved substances between mud and water in lakes: Journal of Ecology, v. 30, p. 147-201.

Much, R. R., and Kemp, G., 1978, Characterization of nonpoint waste sources, Report No. 6, Summary of nonpoint waste loads, Fox Valley Water Quality Planning Agency, Wisconsin, $135 \mathrm{p}$.

Nurnberg, G. K., 1984, The prediction of internal phosphorus load in lakes with anoxic hypolimnia, Limnology and Oceanography, Inc., v. 29 , no. 1 , p. 111-124.

Nurnberg, G. K., and Peters, R. H., 1984, The importance of internal phosphorus load to the eutrophication of lakes with anoxic hypolimnia: Verhandlung Internationale Vereinigung Limnologie, v. 22, p. 190-194.
Porterfield, G., 1972, Computation of fluvial-sediment discharge: U.S. Geological Survey Techniques of Water Resources Investigations, Book 3, Chapter C3, 66 p.

Reckow, K. H., and others, 1980, Modeling phosphorus loading and lake response under uncertainty: a manual and compilation of export coefficients: U.S. Environmental Protection Agency, EPA 44015-80-011, Washington, D.C., 213 p.

Schlinder, J. E., 1971, Food quality and zooplankton nutrition: Journal of Animal Ecology, v. 40, p. 589-595.

Schumacher, E. R., and Burns, L., 1978, General fishery survey and management recommendations-Delavan Lake, 1975: Wisconsin Department of Natural Resources open-file publication, $14 \mathrm{p}$.

Sharpley, A. N., Syers, J. K., and O'Connor, P. W., 1976, Phosphorus inputs into a stream draining an agricultural watershed: Water, Air, and Soil Pollution, v. 6, p. 39-52.

Smith, G. M., 1950, The fresh-water algae of the United States (2d ed.): New York, 719 p.

Smith, V. H., 1983, Low nitrogen to phosphorus ratios favor dominance by blue-green algae in lake phytoplankton: Science, v. 221, p. 669-671.

Sonzogni, W. C., 1974, Effect of nutrient input reduction on the eutrophication of the Madison lakes: Ph.D. thesis, University of Wisconsin, 342 p.

Stauffer, R. E., 1974, Thermocline migration algal bloom relationships in stratified lakes: Madison, Ph.D. thesis, University of Wisconsin.

Theis, T. L., and McCabe, P. J., 1978, Phosphorus dynamics in hypereutrophic lake sediments: Water Research Bulletin, v. 12, no. 9, p. 667-685.

U.S. Department of Commerce, 1982, Evaporation atlas for the contiguous 48 United States: Washington, D.C., NOAA Technical Report NWS33, National Oceanic and Atmospheric Administration, National Weather Service. 1983, Climatological data annual summary, National Oceanic and Atmospheric Administration, Vol. 88, No. 13, 27 p.

1984, Climatological data annual summary, National Oceanic and Atmospheric Administration, Vol. 89, No. 13, 27 p.

1985, Climatological data annual summary, National Oceanic and Atmospheric Administration, Vol. 90, No. 13, 27 p.

U.S. Environmental Protection Agency, 1974, Report on Delavan Lake, Walworth County, Wisconsin: EPA Region V Working Paper No. 36; U.S. Environmental Protection Agency, Region V, 17 p.

1977, Guidelines for the pollutional classification of Great Lakes Harbor sediments: Environmental Protection Agency, Region V.

Verhoff, F. G., Melfi, D. A., and Yalesick, S. M., 1979, Storm travel distance calculations for total phosphorus and suspended material in rivers: Water Resources Research, v. 15, no. 6, p. 1,354-1,360. 
Vollenweider, R. A., 1971, Scientific fundamentals of eutrophication of lakes and flowing waters, with particular reference to nitrogen and phosphorus as factors in eutrophication: Paris Organization for Economic Cooperation and Development, $159 \mathrm{p}$.

1975, Input-output models with special reference to the phosphorus loading concept in limnology: Schweizerische Zeitschrift fur Hydrologie, v. 37, no. 1 , p. 58-84.

Wakeman, R. S., 1985, The preservation of historical copper loadings in the recent sedimentary record of a hard water lake in southeastern Wisconsin: Madison, Master's thesis, University of Wisconsin.

Walkotten, W. J., 1976, An improved technique for sampling streambed sediments: U.S. Department of Agriculture Forest Service, Research Note PNW-281, Pacific Northwest Forest and Range Experimental Station, Portland, Oregon, $11 \mathrm{p}$.

Wisconsin Department of Natural Resources, Office of Inlake Renewal, 1981, Long Lake, Waushara County, feasibility study results: Management Alternatives, $22 \mathrm{p}$.

Wisconsin Department of Natural Resources, Bureau of Water Resources Management, Inlake Renewal Section, 1983, Big Hills Lake, Waushara County, feasibility study results: Management Alternatives, $10 \mathrm{p}$.

Wetzel, R. G., 1983, Limnology (2d ed.): New York, $767 \mathrm{p}$.

Whitaker, J., Barica, J., Kling, H., and Buckley, M., 1978, Efficacy of copper sulfate in the suppression of Aphanizomenon Flos-aquae blooms in prairie lakes: Environmental Pollution, v. 15, no. 3, p. 185-194.

Winter, T. C., 1981, Uncertainties in estimating the water balance of lakes: Water Resources Bulletin, v. 17, no. 1 , p. 82-115.

\section{GLOSSARY OF TECHNICAL TERMS}

Acre-foot-Volume of water required to cover 1 acre to a depth of 1 foot, and equal to $43,560 \mathrm{ft}^{3}$. (Dion and others, 1976)

Aerobic-Having oxygen. (Britton and others, 1975)

Alga, algae, algal-A group of simple primitive plants that live in wet or damp places, and generally are microscopic in size, containing chlorophyll and lacking roots, stems, and leaves. (Britton and others, 1975)

Algal bloom-A high concentration of a particular algal species, amounting to $1 / 2$ million to 1 million cells per liter of water or more. (Britton and others, 1975)

Algicide-A chemical that kills algae. (Britton and others, 1975) 1975)
Anoxic-See anaerobic. (Britton and others, 1975)

Autumn turnover-The mixing of the entire water mass of a lake in the autumn. (Britton and others, 1975)

Average discharge-As defined in the annual series of U.S. Geological Survey reports on surface-water supplythe arithmetic average of all complete water years of record whether or not they are consecutive. Average discharge is not published for less than 5 years of record. The term "average" is generally reserved for average of record and " "mean" is used for averages of shorter periods, namely, daily mean discharge. (Langbein and Iseri, 1960)

Bedrock-A general term for the rock, usually solid, that underlies soil or other unconsolidated, superficial material. (Bates and Jackson, 1980)

Benthic invertebrate-An animal without a backbone, living on or near the bottom of an aquatic environment. (Kuhn and others, 1983)

Benthos, benthic zone-Organisms living in or on the bottom of an aquatic environment. The bottom of a lake or stream. (Dion and others, 1976)

Biomass - The amount of living matter present in a unit area or volume, at any given time. (Dion and others, 1976)

Blue-green algae-A group of algae with a blue pigment, in addition to the green chlorophyll. Blue-green algae group usually causes nuisance conditions in water. (Dion and others, 1976)

Chlorophyll $\boldsymbol{a}$-Chlorophyll $\boldsymbol{a}$ is a green photosynthetic pigment present in plant cells, including algae. The concentration of chlorophyll $a$ in water is a commonly accepted indicator of algal biomass. (Dion and others, 1976)

Color-Color is one control of light transmission through water. High color values in many lakes result from the decomposition of vegetation, which gives the water a brown, tea-like color. Color is determined by a comparison of the water with standardized colored-glass discs and is reported in platinum-cobalt (Pt-CO) units. (Dion and others, 1976)

Cubic feet per second- $f^{3} / \mathrm{s}$ A unit expressing rates of discharge. One cubic foot per second is equal to the discharge of a stream of rectangular cross section, 1 foot wide and 1 foot deep, flowing water an average velocity of 1 foot per second. (Langbein and Iseri, 1960)

Cubic feet per second day - $\left.\left(f^{3} / s\right)-d\right)$ The column of water represented by a flow of 1 cubic foot per second for 24 hours. (Langbein and Iseri, 1960)

Cubic feet per second per square mile- $\left(f t^{3} / s\right) / m i^{2}$ The average number of cubic feet of water per second flowing from each square mile of area drained by a stream, assuming that the runoff is distributed uniformly in time and area. (Langbein and Iseri, 1960) 
Diatom-A unicellular or colonial alga having a siliceous shell. (Dion and others, 1976)

Discharge-In its simplest concept discharge means outflow; therefore, the use of this term is not restricted as to course or location, and it can be applied to describe the volume of the flow of water from a pipe or from a drainage basin. If the discharge occurs in some course or channel, it is correct to speak of the discharge of a canal or of a river. It is also correct to speak of the discharge of a canal or stream into a lake, a stream, or an ocean.

The data in the reports of the Geological Survey on surface water represent the total fluids measured. Thus, the terms discharge, streamflow, and runoff represent water with the solids dissolved in it and the sediment mixed with it. Of these terms, discharge is the most comprehensive. The discharge of drainage basins is distinguished as follows:

Yield-Total water runout or crop; includes runoff plus underflow.

Runoff-That part of water yield that appears in streams.

Streamflow-The actual flow in streams, whether or not subject to regulation, or underflow.

Each of these terms can be reported in total volumes (such as acre-feet) or time rates (such as cubic feet per second or acre-feet per year). The differentiation between runoff as a volume and streamflow as a rate is not accepted. (Langbein and Iseri, 1960)

Dolomite-A carbonate sedimentary rock of which more than 50 percent by weight or by areal percentages under the microscope consists of the mineral dolomite, or a variety of limestone or marble rich in magnesium carbonate. Dolomite occurs in crystalline and noncrystalline forms, is clearly associated and often interbedded with limestone, and usually represents a postdepositional replacement of limestone. Pure dolomite (unless finely pulverized) will effervesce very slowly in cold hydrochloric acid. (Bates and Jackson, 1980)

Drainage area-The drainage are of a stream at a specified location is that area, measured in a horizontal plane, which is enclosed by a drainage divide. (Langbein and Iseri, 1960)

Drainage basin-A part of the surface of the earth that is occupied by a drainage system, which consists of a surface stream or a body of impounded surface water or a body of impounded surface water together with all tributary surface streams and bodies of impounded surface water. (Langbein and Iseri, 1960)

Epilimnion, epilimnetic-The upper, relatively warm, circulating zone of water in a thermally stratified lake. (Dion and others, 1976)

Eutrophication, eutrophic-The natural process of enrichment and aging of a body of water that may be accelerated by the activities of man. Pertains to water bodies in which primary production is high because of a large supply of available nutrients. (Dion and others, 1976)

Evaporation pan-An open tank used to contain water for measuring the amount of evaporation. The U.S. Weather Bureau class A pan is 4 feet in diameter, 10 inches deep, set up on a timber grillage so that the top rim is about 16 inches from the ground. The water level in the pan during the course of observation is maintained between 2 and 3 inches below the rim. (Langbein and Iseri, 1960)

Evaporation, total-The sum of water lost from a given land area during any specific time by transpiration from vegetation and building of plant tissue; by evaporation from water surfaces, moist soil, and snow; and by interception. It has been variously termed "evaporation," evaporation from land areas," evapotranspiration," "total loss," "water losses," and "fly off'. (Langbein and Iseri, 1960)

Evapotranspiration-Water withdrawn from a land area by evaporation from water surfaces and moist soil and by plant transpiration. (Langbein and Iseri, 1960)

Gage height-The water-surface elevation referred to some arbitrary gage datum. Gage height is often used interchangeably with the more general term stage although gage height is more appropriate when used with a reading on a gage. (Langbein and Iseri, 1960)

Green algae-Algae that have pigments similar in color to those of higher green plants. Some forms produce algal mats or floating "moss" in lakes. (Dion and others, 1976)

Hardness - Water hardness is defined as the sum of the polyvalent cations expressed as the equivalent quantity of calcium carbonate $\left(\mathrm{CaCO}_{3}\right)$. As a general rule, hard-water lakes are more productive of plants and animals than softwater lakes, but there are many exceptions. (Dion and others, 1976)

Hydrology-The science encompassing the behavior of water as it occurs in the atmosphere, on the surface of the ground, and underground. (Langbein and Iseri, 1960)

Hypolimnion, hypolimnetic-The lower, relatively cold, noncirculating water zone in a thermally stratified lake. (Dion and others, 1976)

Limnology-That branch of hydrology pertaining to the study of lakes. (Langbein and Iseri, 1960)

Littoral zone-The shallow zone of a body of water where light penetrates to the bottom. (Dion and others, 1976)

Load-The amount, by weight or volume, of a substance transported by a stream past a specific point during a specified length of time. (Kuhn and others, 1983)

Lugol's solution-A preserving solution for algae made from iodine crystals, potassium iodide, glacial acetic acid, and distilled water. (Dion and others, 1976) 
Maximum depth-The difference, in feet of elevation, between the bottom and the surface of the lake. (Dion and others, 1976)

Mean depth-The mean depth, in feet, for a specified lake stage, is obtained by dividing the volume of the lake by its area. (Dion and others, 1976)

Mesotrophic-Intermediate stage in lake classification between the oligotrophic and eutrophic stages, in which primary production occurs at a greater rate than in oligotrophic lakes, but at a lesser rate than in eutrophic lakes. This is due to a moderate supply of nutrients. (See also Eutrophic and Oligotrophic.) (Dion and others, 1976)

Metalimnion, metalimnetic-The middle layer of water in a thermally stratified lake, in which temperature decreases rapidly with depth. (Dion and others, 1976)

Moraine-A mound, ridge, or other distinct accumulation of unsorted, unstratified glacial drift, predominantly till, deposited chiefly by direct action of glacier ice, in a variety of topographic landforms that are independent of control by the surface on which the drift lies. (Bates and Jackson, 1980)

Nutrient-Any chemical element, ion, or compound that is required by an organism for the continuation of growth, reproduction, and other life processes. (Dion and others, 1976)

Oligotrophic-Pertaining to waters in which primary production is low as a consequence of a small supply of available nutrients. (Britton and others, 1975)

Ordovician-The second earliest period of the Paleozoic era (after the Cambrian and before the Silurian), thought to have covered the span of time between 500 and 440 million years ago. (Bates and Jackson, 1980)

Organic-Pertaining or relating to a compound containing carbon, especially as an essential component. Organic compounds usually have hydrogen bonded to the carbon atom. (Bates and Jackson, 1980)

Paleozoic-An era of geologic time, from the end of the Precambrian to the beginning of the Mesozoic, or from about 570 to about 225 million years ago. (Bates and Jackson, 1980).

$p H-\mathrm{pH}$ is the negative logarithm of the effective hydrogen-ion concentration, expressed as a number from 0 to 14 . A pH of 7 is neutral, a pH of less than 7 is acidic, and a pH of greater than 7 is basic. (Dion and others, 1976)

Phytoplankton, phytoplanktonic-The plant part of the plankton. (Dion and others, 1976)

Plankton-The individual plant, animal, or bacterium in the plankton community. (Cole, 1979)

Precambrian-All geologic time, and its corresponding rocks, before the beginning of the Paleozoic; it is equivalent to about 90 percent of geologic time. Precambrian time has been divided according to several different systems, all of which use the presence or absence of evidence of life as a criterion. (Bates and Jackson, 1980)

Primary production-The synthesis of organic compounds by green plants in the presence of elements and light energy. (Dion and others, 1976)

Profundal zone-The deep zone of a water body in which plant growth is limited by the absence of light. (Dion and others, 1976)

Quaternary-The second period of the Cenozoic era, following the Tertiary; also, the corresponding system of rocks. It began 2 to 3 million years ago and extends to the present. It consists of two grossly unequal epochs: the Pleistocene, up to about 8,000 years ago, and the Holocene since that time. The Quaternary was originally designated an era rather than a period, with the epochs considered to be periods, and it is still sometimes used as such in the geologic literature. The Quaternary may also be incorporated into the Neogene, when the Neogene is designated as a period of the Tertiary era. (Bates and Jackson, 1980)

Recurrence interval (return period)-The average interval of time within which the given flood will be equaled or exceeded once. (Langbein and Iseri, 1960)

Secchi-disc visibility-Secchi-disc visibility is the depth at which a white-and-black disc ( 8 inches in diameter) disappears from view when lowered into the water. Secchi-disc visibility depth is a measure of water transparency or clarity. Because changes in biological production can cause changes in the color and turbidity of a lake, Secchi-disc visibility often is used as a gross measure of the plankton in the water. (Dion and others, 1976)

Sediment-Fragmental material, both mineral and organic, that is in suspension or is being transported by the water mass or has been deposited on the bottom of the aquatic environment. (Dion and others, 1976)

Silica-The chemically resistant dioxide of silicon: $\mathrm{SiO}_{2}$. It occurs naturally in five crystalline polymorphs (the minerals quartz, tridymite, cristobalite, coesite, and stishovite); in cryptocrystalline form (chalcedony); in amorphous and hydrated forms (opal); in less pure forms (e.g., sand, diatomite, tripoli, chert, flint); and combined in silicates as an essential constituent of many minerals. (Bates and Jackson, 1980)

Silurian-A period of the Paleozoic, thought to have covered the span of time between 440 and 400 million years ago; also, the corresponding system of rocks. The Silurian follows the Ordovician and precedes the Devonian; in the older literature, it was sometimes considered to include the Ordovician. (Bates and Jackson, 1980) 
Sorption, sorb-To take up and hold by either adhesion or incorporation. A collective term for absorption and adsorption. (Dion and others, 1976)

Species-The basic or final unit for the classification of organisms. (Dion and others, 1976)

Specific conductance-Specific conductance is a measure of the water's ability to conduct an electric current and is used as an approximation of the dissolved-solids concentration in the water. It is measured in units of microsiemens (formerly micromhos) per centimeter at $25^{\circ}$ Celsius. (Dion and others, 1976)

Streamflow-The discharge that occurs in a natural channel. Although the term discharge can be applied to the flow of a canal, the word streamflow uniquely describes the discharge in a surface stream course. The term "streamflow" is more general than runoff, as streamflow may be applied to discharge whether or not it is affected by diversion or regulation. (Langbein and Iseri, 1960)

Stream-gaging station-A gaging station where a record of discharge of a stream is obtained. Within the Geological Survey this term is used only for those gaging stations where a continuous record of discharge is obtained. (Langbein and Iseri, 1960)

Surface water-Water on the surface of the earth. (Langbein and Iseri, 1960)

Suspended sediment-Fragmented material, both mineral and organic, that is maintained in suspension in water. (Dion and others, 1976)
Thermal stratification (of a lake)-Vertical temperature stratification that shows the following: the upper layer of the lake, known as the epilimnion, in which water temperature is virtually uniform; a stratum next below, known as the thermocline, in which there is a marked drop in temperature per unit of depth; and the lowermost region or stratum, known as the hypolimnion, in which the temperature from its upper limit to the bottom is nearly uniform. (Langbein and Iseri, 1960)

Unconsolidated material-(a) A sediment that is loosely arranged or unstratified, or whose particles are not cemented together, occurring either at the surface or at depth. (b) Soil material that is in a loosely aggregated form. (Bates and Jackson, 1980)

Water quality - That phase of hydrology that deals with the kinds and amounts of matter dissolved and suspended in natural water, the physical characteristics of the water, and the ecological relationships between aquatic organisms and their environment. (Dion and others, 1976)

Water year-In Geological Survey reports dealing with surface-water supply, the 12-month period, October 1 through September 30. The water year is designated by the calendar year in which it ends and which includes 9 of the 12 months. Thus, the year ended September 30, 1959, is called the " 1959 water year". (Langbein and Iseri, 1960)

Zooplankton, zooplanktonic-The animal part of the plankton. (Dion and others, 1976) 


\title{
HYDROLOGY AND WATER QUALITY OF DELAVAN LAKE IN SOUTHEASTERN WISCONSIN
}

\author{
By \\ Stephen J. Field and Marvin D. Duerk
}

Water-Resources Investigations Report 87-4168

\section{APPENDICES}

Appendix 1 (a-d)-Phytoplankton populations of Delavan Lake, 1984 and 1985 water years.

Appendix 2 (a-d)-Zooplankton populations of Delavan Lake, 1984 and 1985 water years.

Appendix 3 (a-d)-Benthic macroinvertebrates of Delavan Lake, 1984 and 1985 water years.

Appendix 4 (a-h)-Water-quality loads at Jackson Creek, 1984 and 1985 water years.

Appendix 5 (a-h)-Water-quality loads at Jackson Creek tributary, 1984 and 1985 water years.

Appendix 6 (a-h)-Water-quality loads at Delavan Lake tributary 2, 1984 and 1985 water years.

Appendix 7 (a-h)-Water-quality loads at Delavan Lake outlet, 1984 and 1985 water year. 
Appendix 1a-Phytoplankton populations, (organisms $/ \mathrm{mL}$ ), for Delavan Lake, Southwest End, 1984 Water Year.
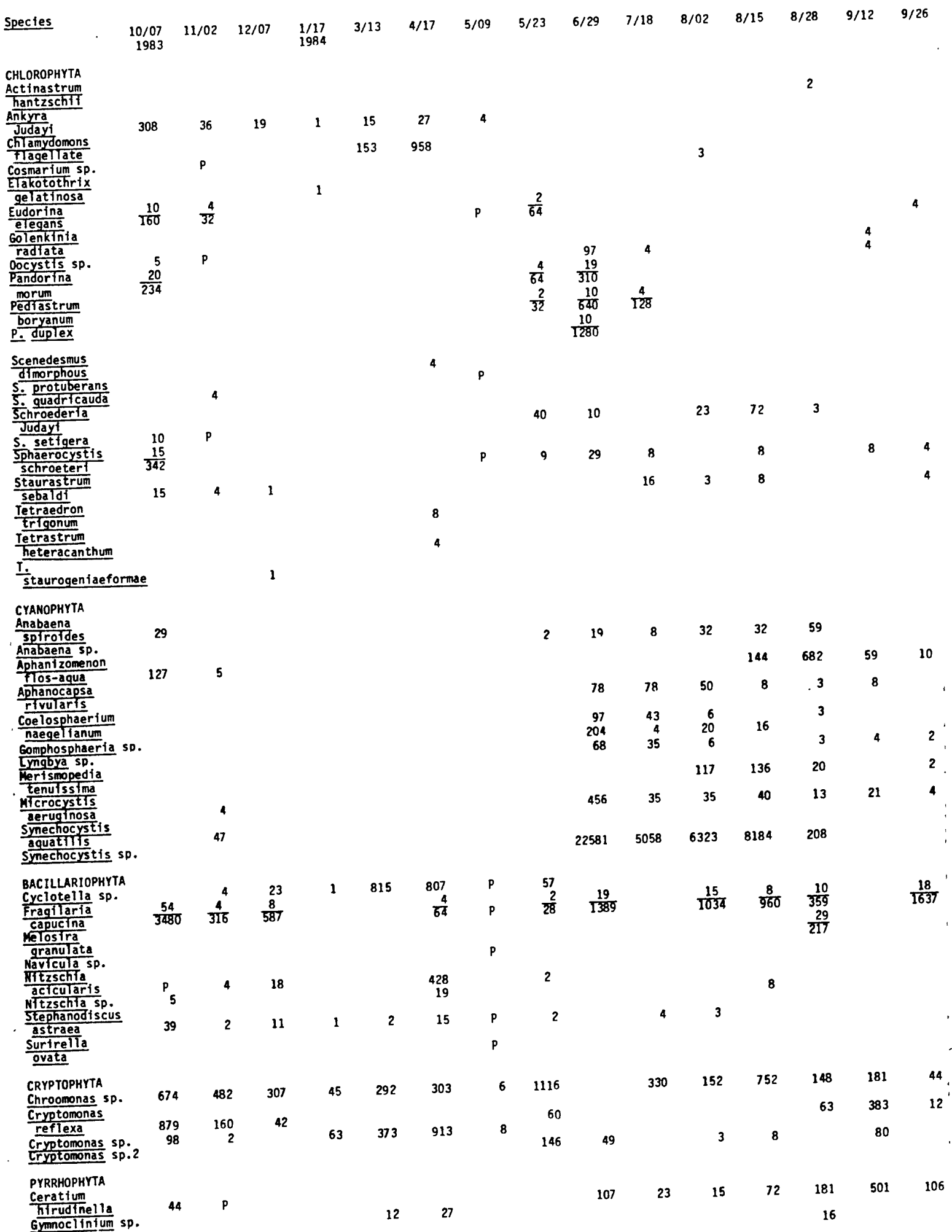

Gymnoclintum sp.

CHRYSOPHYTA

Dinobryon

Dínobryon SP.

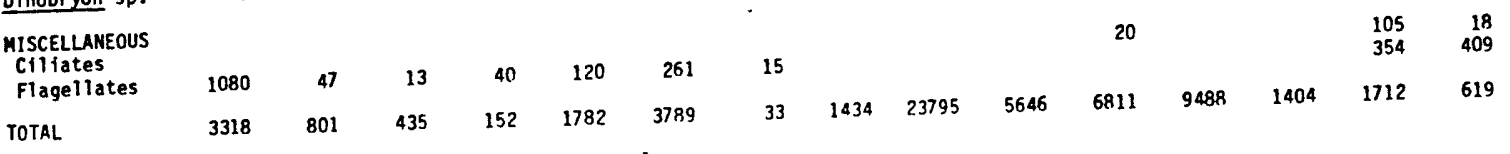

Notes: 1. "pn indicates presence of spectes in the sample. 2. Where states as a that colony. 
Appendix 1b-Phytoplankton populations (organisms/mL), for Delavan Lake, Northeast End, 1984 Water Year. Species

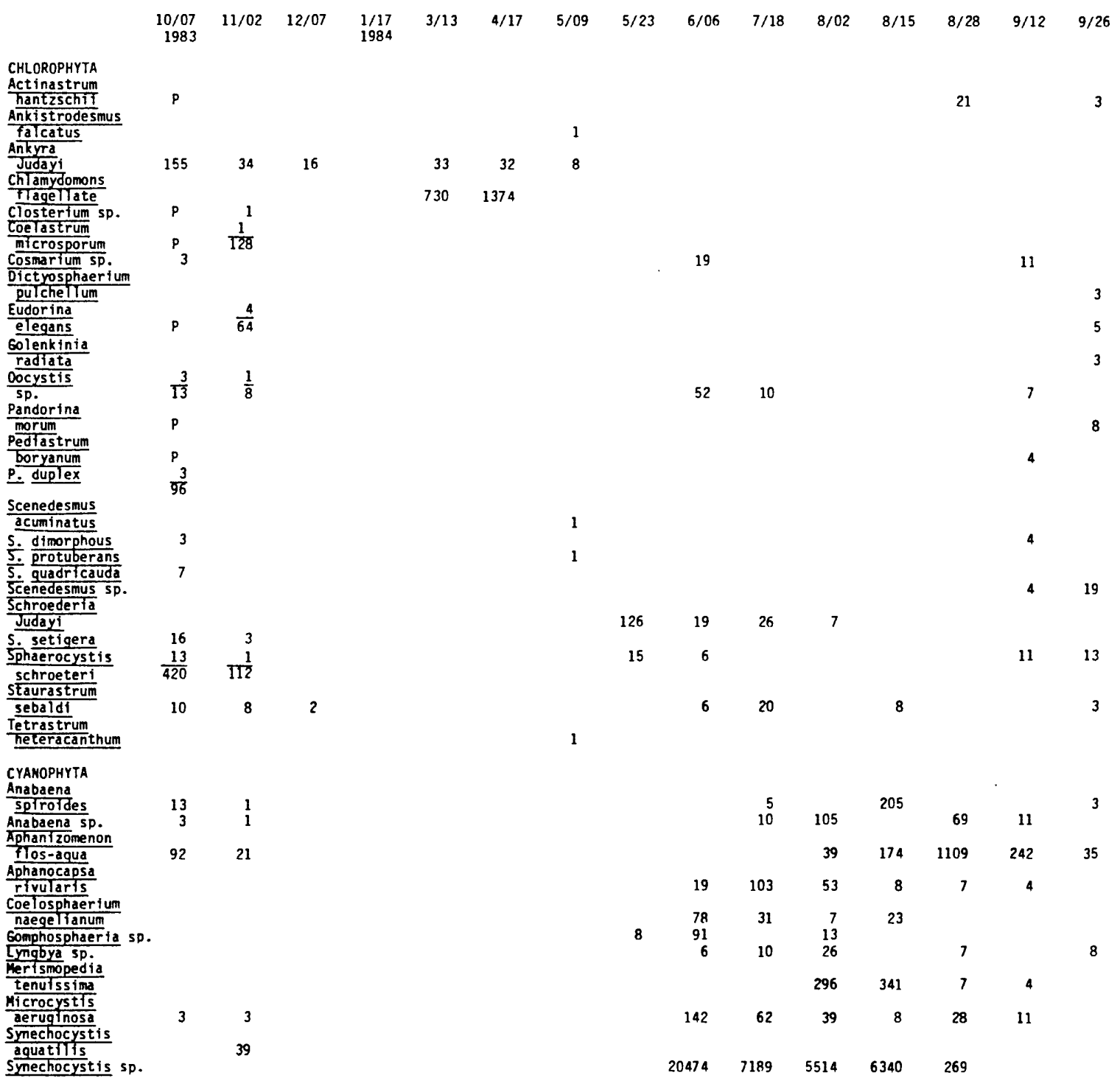

BaCTLLARIOPHYTA

BACILLARIOPHYTA

$\begin{array}{llll}\text { Cyclotella } & & & \\ \frac{\text { Fragilaria }}{\text { capucina }} & \frac{46}{2698} & \frac{8}{505} & \frac{4}{217}\end{array}$

$\begin{array}{rrr}388 & 1173 & 39 \\ & \frac{1}{5}\end{array}$

colosira

granulata

Navicula sp.

acicularis

Stephanodiscus

astraea

Surirella

cryptophyta

$\begin{array}{llllll}\text { Chroomonas sp. } & 570 & 290 & 220 & 590 & 536\end{array}$

Cryptomona

reflexa

Cryptomonas sp.

PYRRHOPHYTA

Ceratium

hrudinella

Geridinium sp.

CHRYSOPHYTA

Mallomonas sp.

$\begin{array}{ccc} & 21 & 46 \\ \frac{46}{2698} & \frac{8}{505} & \frac{4}{217}\end{array}$

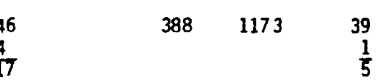

$\begin{array}{ccc}19 & \frac{31}{17} & \frac{13}{7} \\ 1704 & \frac{7}{659}\end{array}$

MISCELLANEOUS

Ciliates

Flagellates

$\begin{array}{lllllll}319 & 37 & 20 & 18 & 415 & 338 & 18\end{array}$

10

$\frac{14}{103} \frac{11}{1154} \frac{29}{2031}$

TOT:L

$\begin{array}{llllll}1674 & 605 & 370 & 1062 & 2695 & 5532\end{array}$

$113 \quad 718 \quad 20975$

26

$\begin{array}{rr}97 & 32 \\ 628 & 372\end{array}$ 
66 Appendix 1c-Phytoplankton populations (organisms/mL) for Delavan Lake, Southwest End, 1985 Water Year. Species
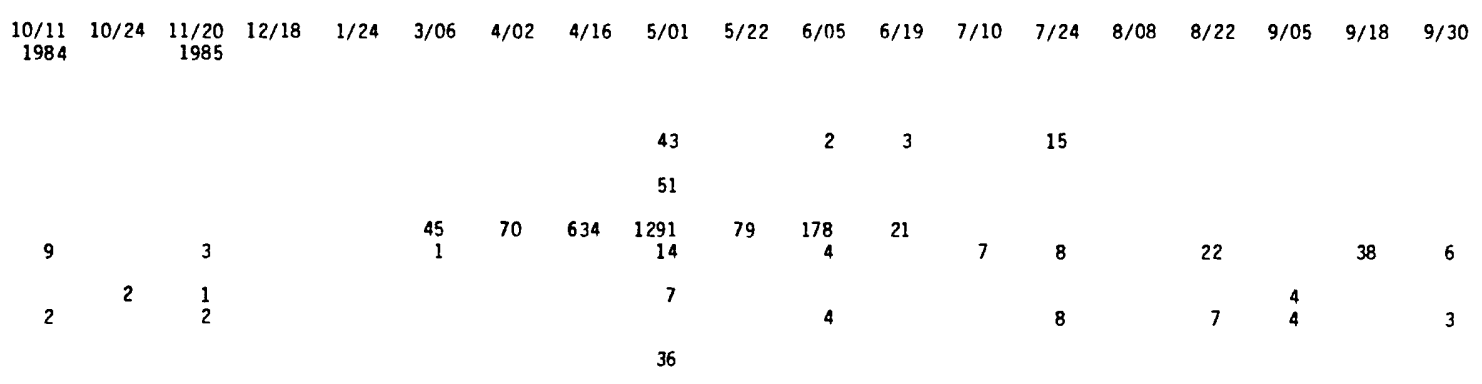

Species

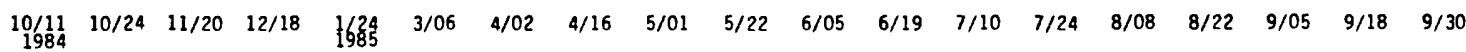

CYANOPHYTA

Anabaena

Anabaena

spirotes

Aphanizomenon

flos-aqua 17

Aphanocapsa

Aphanocapsa sp.

2

$\begin{array}{lllllll}7 & 2 & 4 & 12 & 7 & 8\end{array}$

$\begin{array}{lrr}7 & 19 & 2\end{array}$

phanocapsa

Trmineticus

Chroococcus

coelosphaerium

naegelfanum

Lymgbya $5 p$.

acruginosa

synechocystis sp.

23

SACILLARIOPHYTA

Asterfonella

cyclotelia

cyclotella

cyclotella 5 .

Cyclotella Sp.

$\frac{\text { capucina }}{\text { Gomphonema }} 1$ ip.

helostra

M. granulata

Nitzschta

$\frac{\text { actcularis }}{\text { Nitzschia so }}$

Nitzschia 50.
Stephanodiscus

astraea

s. tenfus

ovata

symedra sp.

$\begin{array}{lllllllll}18 & 1197 & 618 & 58 & 15 & 61 & 108 & 7 & 3\end{array}$

CRYPTOPHYTA

$\begin{array}{lllllllllllllllllllll}\text { Chroomonas Sp. } & 216 & 152 & 174 & 356 & 385 & 80 & 1040 & 463 & 916 & 22 & 772 & 876 & 1600 & 326 & 561 & 137 & 29 & 76 & 5\end{array}$ $\begin{array}{lllllllllllllllllllll}\frac{\text { Cryptomonas }}{\text { reflexa }} & 159 & 196 & 105 & 151 & 81 & 11 & 275 & 419 & 1580 & 48 & 198 & 315 & 36 & 318 & 280 & 238 & 233 & 76 & 42\end{array}$ Cryptomonas sp. 25

EUGLENOPHYTA

Trachelomonas sp.

PYRRHOPHYTA

Ceratium

Peridinfum so.

$\begin{array}{rrrrrrr}25 & 91 \\ \frac{30}{4062} & \frac{19}{3302} & \frac{42}{556} & \frac{11}{430} & \frac{1}{20} & & \frac{22}{757}\end{array}$

$\begin{array}{llll}\frac{15}{842} & \frac{15}{1576} & \frac{7}{216} & \frac{15}{803}\end{array}$

13

$\begin{array}{rrrrrrrrrr}1 & 2 & 3 & 14 & & 8 & 22 & 4 & & 2 \\ 15 & 2 & 9 & 14 & 23 & & 36 & 26 & 13 & 2 \\ & 37 & 10 & 4329 & 379 & 76 & 58 & 7 & & 2\end{array}$

MISCELLANEOUS

Ciliates
flaqeliates

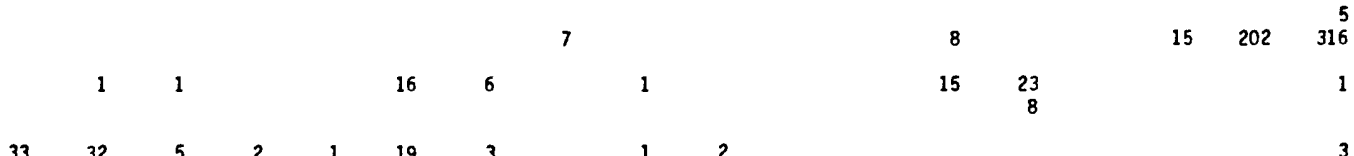

TOTAL

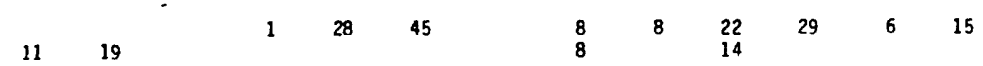

$\begin{array}{lllllllllllllllllll}248 & 169 & 58 & 38 & 66 & 55 & 71 & 109 & 1774 & 35 & 13 & 12 & 498 & 667 & 758 & 224 & 292 & 638 & 52\end{array}$ 
Appendix 1d-Phytoplankton populations (organisms/mL) for Delavan Lake, Northeast End, 1985 Water Year. 67 Spectes

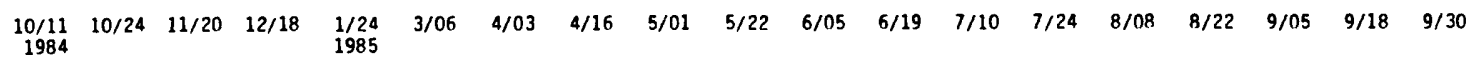
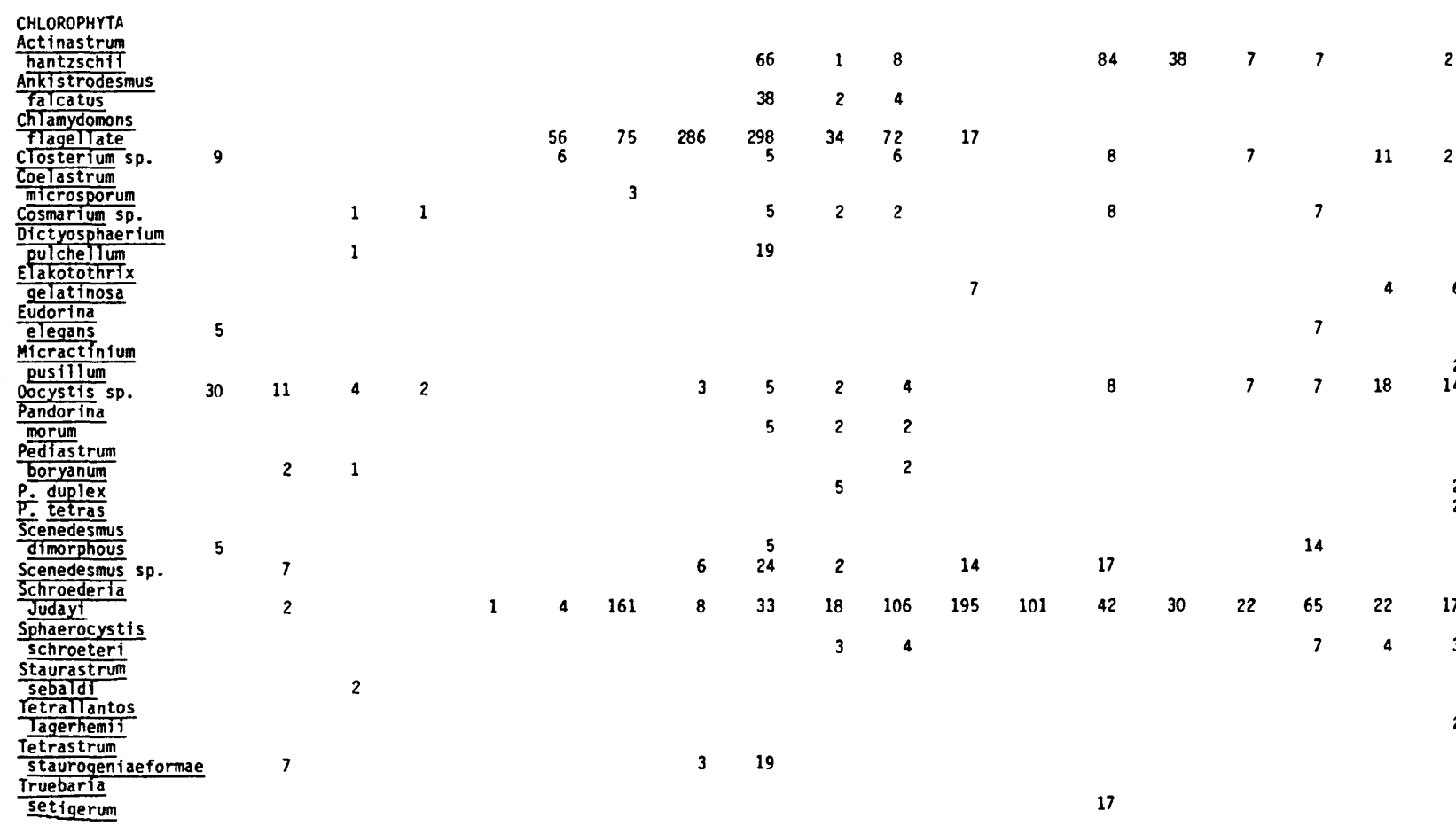

Species

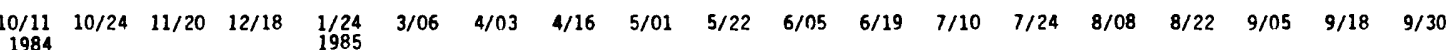

\begin{tabular}{|c|c|c|c|c|c|c|c|c|c|c|c|}
\hline \multicolumn{12}{|l|}{$\begin{array}{l}\text { CYANOPHYTA } \\
\text { Anabaena }\end{array}$} \\
\hline$\frac{\text { Anabaena }}{\text { circinalis }}$ & & 2 & 104 & 779 & 14 & 177 & 136 & 123 & 22 & 11 & 33 \\
\hline Anabaena & & & & & & & & & & & \\
\hline spiroides & & 1 & & & & 59 & 8 & & & & \\
\hline $\begin{array}{l}\text { Anabaena sp. } \\
\text { Aphanizomenon }\end{array}$ & 5 & & & & & & & & & & \\
\hline flos-agua & & & & 195 & 3398 & 3022 & 2341 & 3153 & 1674 & 1187 & 174 \\
\hline Aphanocapsa sp. & & & 2 & & 22 & 51 & 15 & & 7 & & 2 \\
\hline$\frac{\text { Chroococcus }}{\text { dfspersus }}$ & & & & & & & & 14 & & 7 & \\
\hline naegeltanum & & & & & & & & & & & 2 \\
\hline Lymgbya sp. & 5 & & & & 7 & 8 & 8 & & 14 & & \\
\hline Hitcrocystis & & & & & & & & & & & \\
\hline deruginosa & 30 & & & & & 8 & 15 & 22 & 22 & 18 & 33 \\
\hline symechocystis SD. & & 30 & 9 & 2164 & 5144 & 118 & 68 & 22 & 43 & & \\
\hline
\end{tabular}

BACILLARIOPHYTA

Cyclotella

meneghiniana

Cyclotella Sp.

Fragliarla

capucina

67

673

binderan

M. granulata

Mavicula $\mathbf{s}$

actcular

acicularis

stephanodiscus

astraea

S. $\frac{\text { tenius }}{\text { Surtrella }}$

ovata

symedra sp.

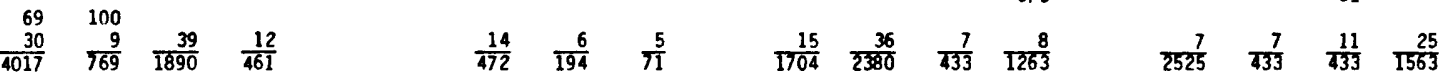

CRYPTOPHYTA

$\begin{array}{llllllllllllllllllllll}\text { Chroomonas sp. } & 964 & 241 & 147 & 253 & 373 & 922 & 744 & 122 & 137 & 33 & 280 & 880 & 418 & 303 & 174 & 7 & 202 & 162 & 5\end{array}$

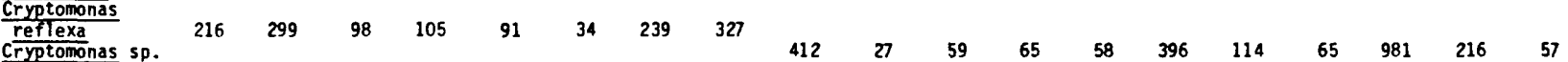
Cryptomonas sp.2 $87 \quad 11$

EUGLENOPHYTA

Trachelomonas Sp.

Phacus sp.

PYRRHOPHYTA

Ceratium

Peridinfum sp.

$\begin{array}{lll}289 & 25 \quad 1\end{array}$

67

MISCELLANEOUS

Flagellates

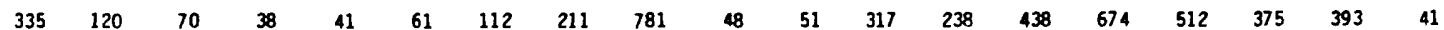

TOTAL

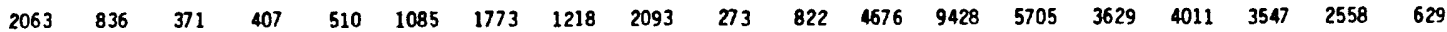

1. The numerator is the number of orqanisms and the denominator is the total number of individuals in that colony. 
Appendix 2a-Zooplankton populations $\left(\right.$ count $\left./ \mathrm{m}^{3}\right)$ for Delavan Lake, Northeast End, 1984 Water Year.

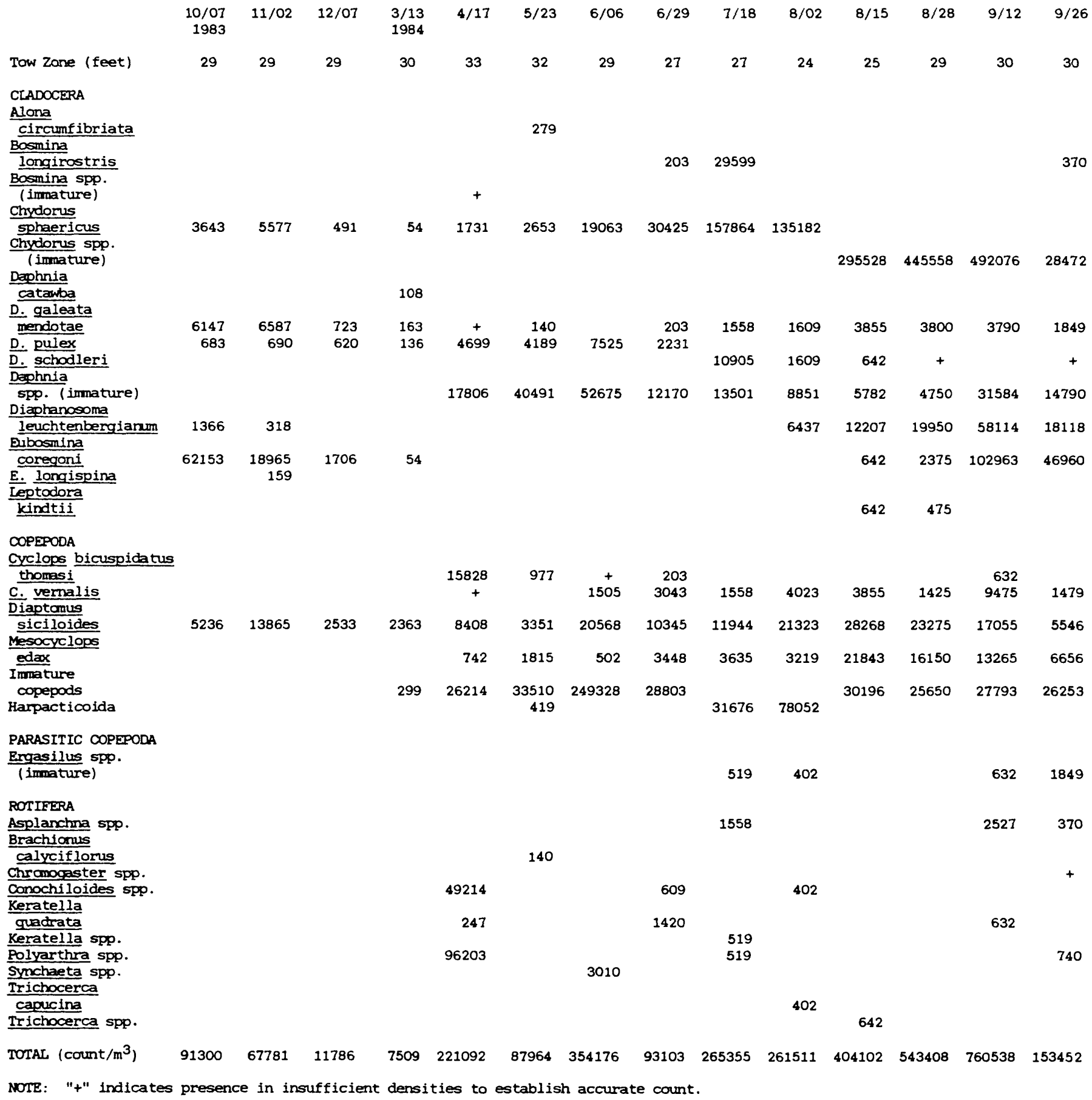



\%ั

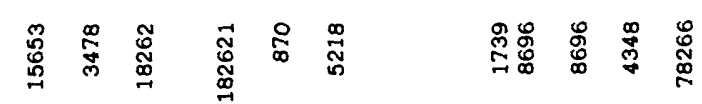

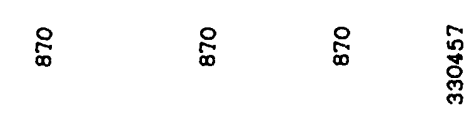
$\frac{2}{2}$

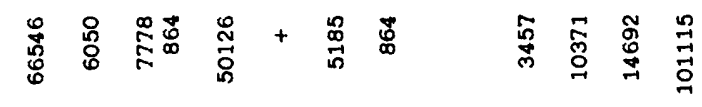

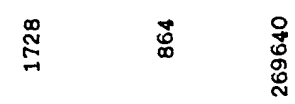
잉

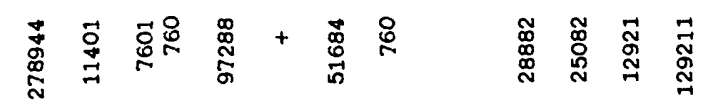

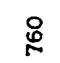

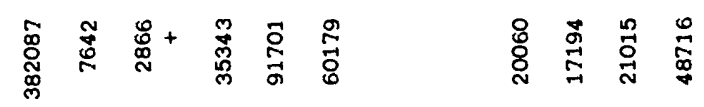

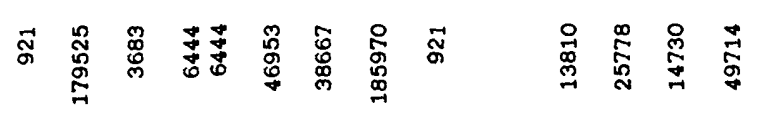

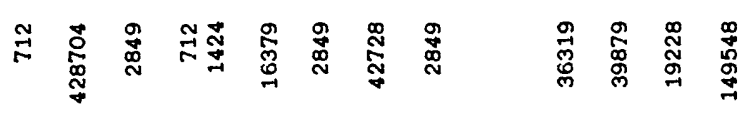

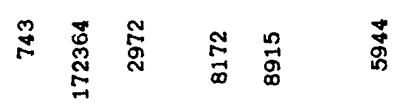
+兽兽喜

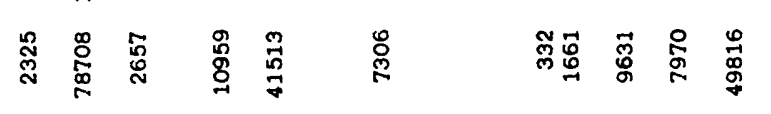

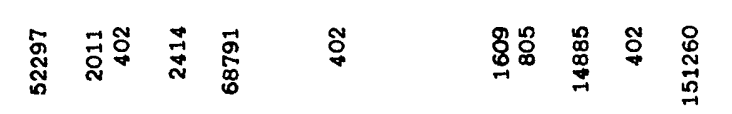

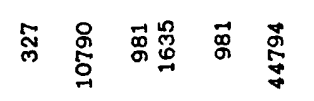

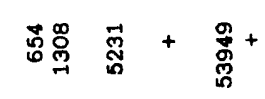

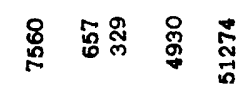

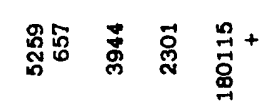

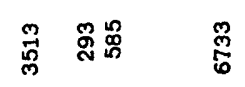

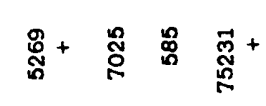

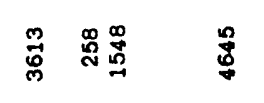

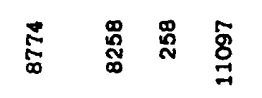

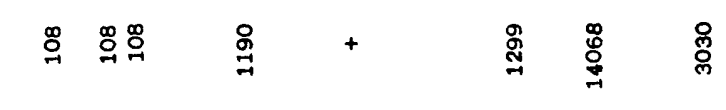
\%

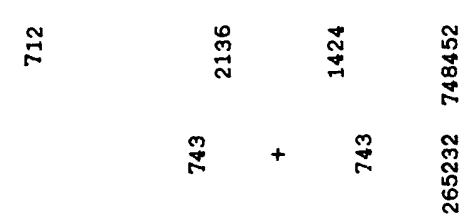
鱼:
产 冚 ะ

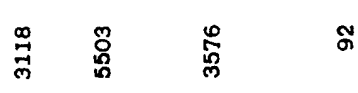

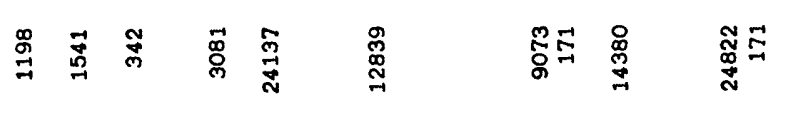

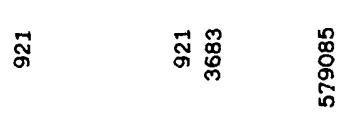

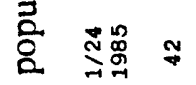
$\approx+$

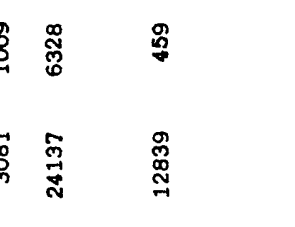

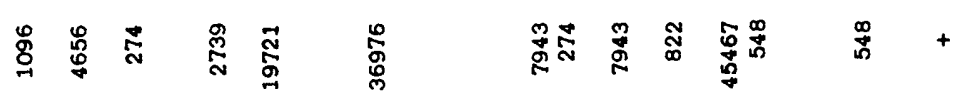

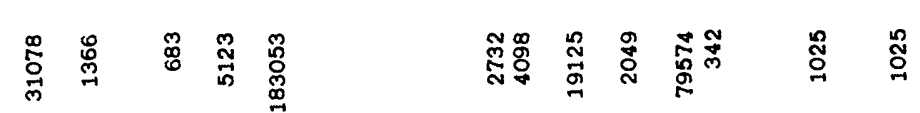
₹า \&

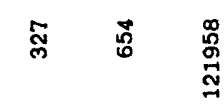
总
กิ
츨

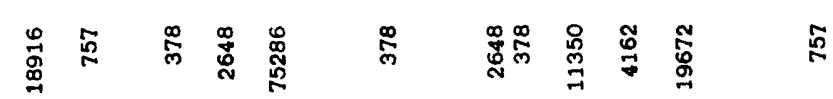

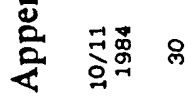

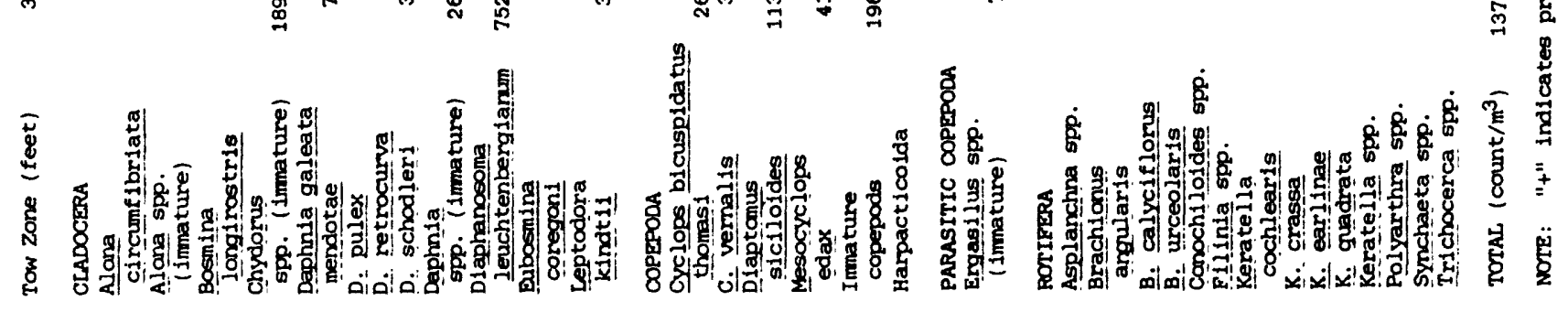




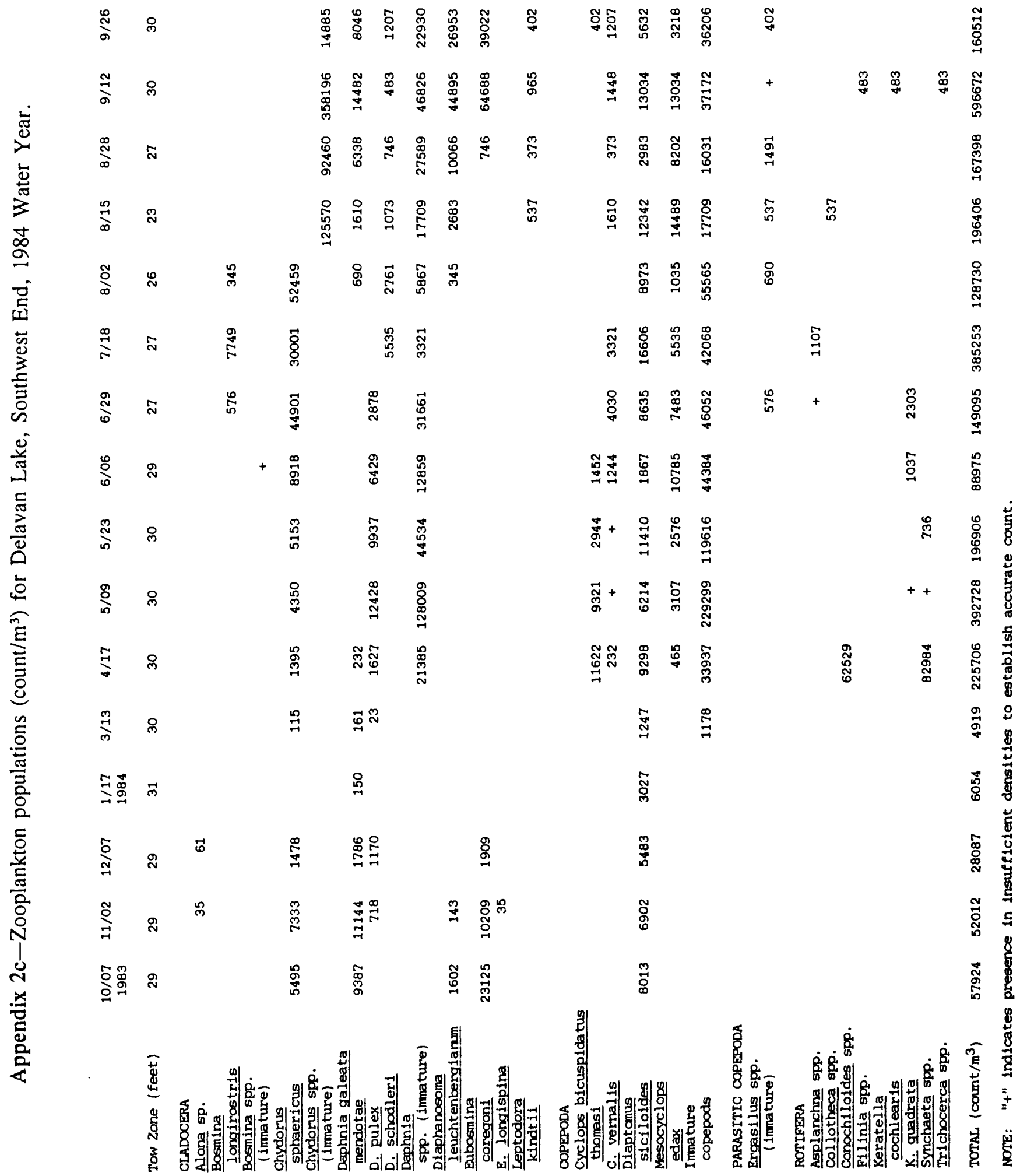



$\stackrel{\circ}{\circ} \stackrel{\circ}{\circ}$

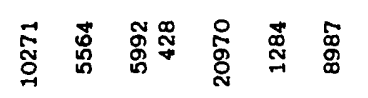

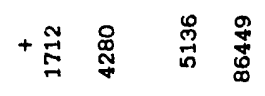
$\stackrel{\infty}{\Im}$
$\stackrel{\infty}{\Im}$
栾怘
$\stackrel{\infty}{\circ} 8$

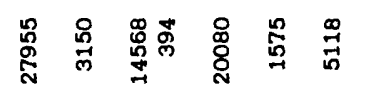

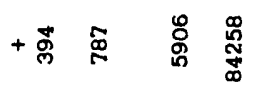

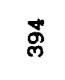
苛照芯

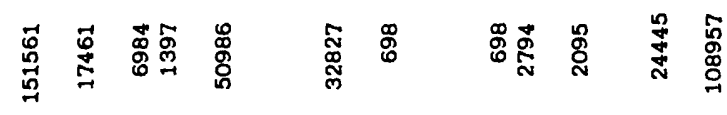
品

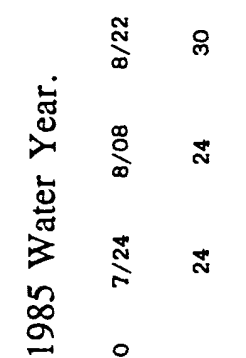

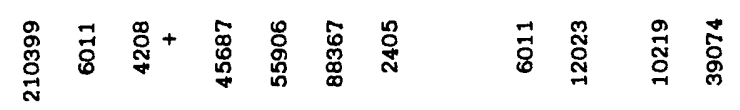

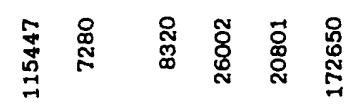

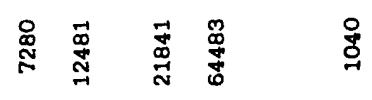

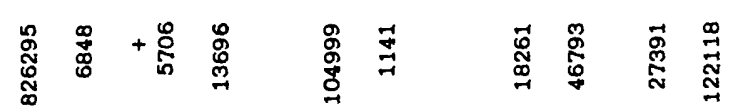
룽

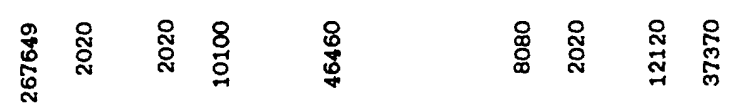

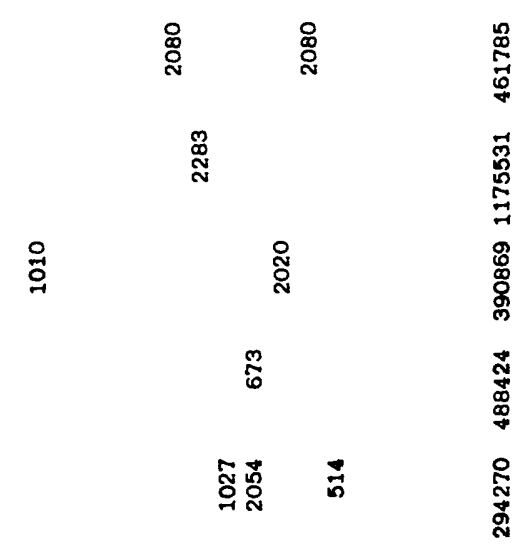

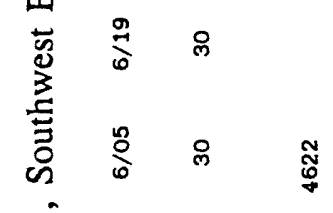

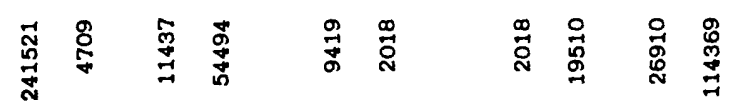
芯

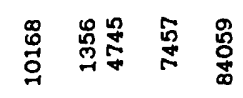

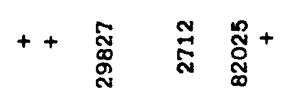

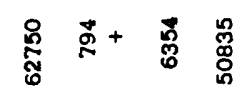

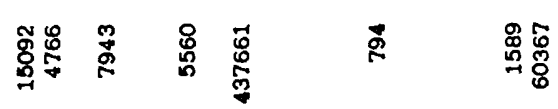

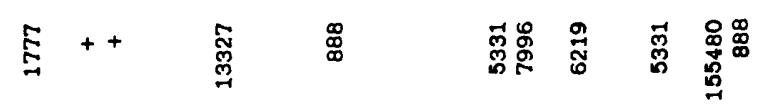
窎
递尔
密 品

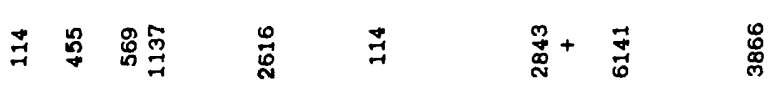
言突兽
ำ
总 量

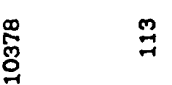

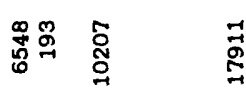
苛 嵒 尺
:

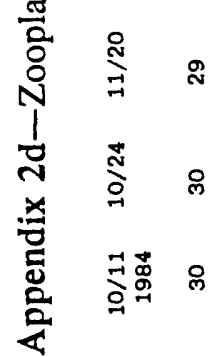

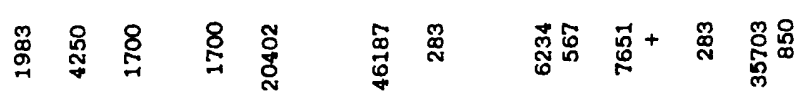

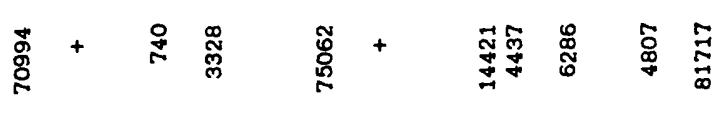
$\stackrel{\circ}{\circ}$

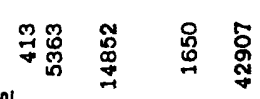

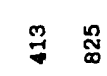
$\stackrel{0}{1}$

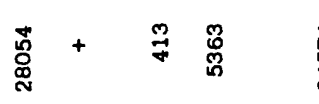
葛
要

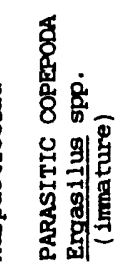

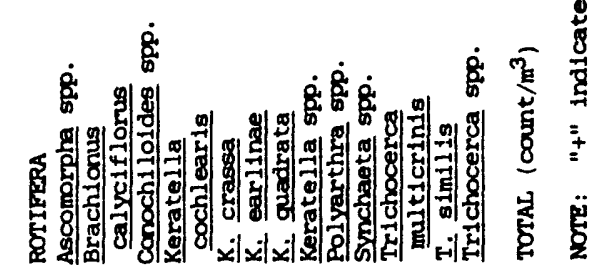


Appendix 3a-Benthic macroinvertebrate count, Delavan Lake, May 15, 1984.

[units in organisms per square meter]

\begin{tabular}{|c|c|c|c|c|c|c|c|c|c|c|c|c|}
\hline $\begin{array}{l}\text { Site number } \\
\text { (fig. 4) }\end{array}$ & 1 & 2 & 3 & 4 & 5 & 6 & 7 & 8 & 9 & 10 & 11 & 12 \\
\hline $\begin{array}{l}\text { Sampling depth } \\
\text { (in feet) }\end{array}$ & 6 & 10 & 20 & 30 & 40 & 20 & 52 & 75 & 45 & 30 & 15 & 10 \\
\hline \multicolumn{13}{|l|}{ INSECTA } \\
\hline \multicolumn{13}{|l|}{ Diptera } \\
\hline Chironomidae & 1,938 & 904 & 732 & 431 & 344 & 3,961 & 86 & 5,124 & 86 & 388 & 1,679 & 120 \\
\hline *Chaoborus sp. & & & & & 258 & & 861 & & 301 & & & \\
\hline \multicolumn{13}{|l|}{ Trichoptera } \\
\hline Limnephilidae & & & & & & 43 & & & & & & \\
\hline \multicolumn{13}{|l|}{ Hemiptera } \\
\hline ^Notonectidae & & 86 & & & & & & & & & & \\
\hline \multicolumn{13}{|l|}{ GASTROPODA } \\
\hline \multicolumn{13}{|l|}{ Pulmonata } \\
\hline Physidae & + & + & & & & & & & & & & \\
\hline Planorbidae & + & + & & & & & & & & & & + \\
\hline \multicolumn{13}{|l|}{ PELECYPODA } \\
\hline Sphaeriidae & + & + & & & & & & & & & & + \\
\hline \multicolumn{13}{|l|}{ OLIGOCHAETA } \\
\hline Tubificidae & & & + & & & + & & + & & & + & \\
\hline HIRUDTNEA & & & & & & 172 & & & & & & \\
\hline
\end{tabular}

1. Each number that appears represents a sample.

2. + denotes presence in sample. 
Appendix 3b-Benthic macroinvertebrate count, Delavan Lake, September 15, 1984.

[units in organisms per square meter]

\begin{tabular}{|c|c|c|c|c|c|c|c|c|c|c|c|c|}
\hline $\begin{array}{l}\text { Site number } \\
\text { (fig. 4) }\end{array}$ & 1 & 2 & 3 & 4 & 5 & 6 & 7 & 8 & 9 & 10 & 11 & 12 \\
\hline $\begin{array}{l}\text { Sampling depth } \\
\text { (in feet) }\end{array}$ & 6 & 10 & 20 & 30 & 40 & 20 & 52 & 75 & 45 & 30 & 15 & 10 \\
\hline \multicolumn{13}{|l|}{ INSECTA } \\
\hline Chironomidae & $\frac{344}{344}$ & $\frac{43}{431}$ & $\frac{86}{43}$ & $\frac{172}{43}$ & $\frac{43}{0}$ & $\frac{258}{0}$ & $\frac{0}{43}$ & $\frac{388}{818}$ & & & $\frac{129}{258}$ & $\frac{129}{0}$ \\
\hline *Chaoborus sp. & & & $\frac{129}{129}$ & $\frac{560}{431}$ & $\frac{1,033}{517}$ & & $\frac{1,206}{560}$ & $\frac{129}{0}$ & $\frac{990}{172}$ & $\frac{603}{560}$ & & $\frac{0}{86}$ \\
\hline *Dixidae & & & & & & $\frac{43}{0}$ & & & & & & \\
\hline \multicolumn{13}{|l|}{ Ephemeroptera } \\
\hline Caenidae & & & & & & & & $\frac{0}{86}$ & & & & \\
\hline \multicolumn{13}{|l|}{ GASTROPODA } \\
\hline $\begin{array}{l}\text { Physsidae } \\
\text { Lymaeidae }\end{array}$ & $\begin{array}{l}+ \\
+\end{array}$ & + & + & & & & & & & & & + \\
\hline Planorbidae & + & + & + & & & & & + & & & + & + \\
\hline Ancrlidae & & & & & & $\frac{129}{43}$ & & & & & & \\
\hline \multicolumn{13}{|l|}{ Prosobranchia } \\
\hline Valvatidae & & + & + & & & & & + & & & + & + \\
\hline \multicolumn{13}{|l|}{ PELECYPODA } \\
\hline Sphaeriidae & + & + & + & & & & & + & & & + & + \\
\hline \multicolumn{13}{|l|}{ CRUSTACEA } \\
\hline \multicolumn{13}{|l|}{ Cladocera } \\
\hline Leptodoridae & & & & & + & & & & & & & \\
\hline «Leptodora kindtii & & & & $\frac{43}{43}$ & $2 \underline{0}$ & & & $\frac{172}{0}$ & $\frac{43}{0}$ & $\frac{43}{0}$ & & $\frac{43}{0}$ \\
\hline \multicolumn{13}{|l|}{ OLIGOCHAETA } \\
\hline Tubificidae & + & + & & & & & & & & & & \\
\hline HIRUDINEA & & & & & & $\frac{560}{0}$ & & & & & & \\
\hline \multicolumn{13}{|l|}{ HYDROZOA } \\
\hline Hydroida & & & & & & $\frac{86}{0}$ & & & & & & \\
\hline
\end{tabular}

1. Where two numbers appear, the numerator is the first sample and the denominator is the second sample.

2. + denotes presence in sample.

3. * means not benthic but found in sample as indicated. 
Appendix 3c -Benthic macroinvertebrate count, Delavan Lake, May 23, 1985.

[units in organisms per square meter]

\begin{tabular}{|c|c|c|c|c|c|c|c|c|c|c|c|c|}
\hline $\begin{array}{l}\text { Site number } \\
\text { (fig. } 4 \text { ) }\end{array}$ & 1 & 2 & 3 & 4 & 5 & 6 & 7 & 8 & 9 & 10 & 11 & 12 \\
\hline $\begin{array}{l}\text { Sampling depth } \\
\text { (in feet) }\end{array}$ & 6 & 10 & 20 & 30 & 40 & 20 & 52 & 75 & 45 & 30 & 15 & 10 \\
\hline \multicolumn{13}{|l|}{ INSECTA } \\
\hline \multirow[t]{2}{*}{ Chironomidae } & $\underline{215}$ & $\underline{431}$ & $\underline{215}$ & $\underline{258}$ & & $\underline{517}$ & & $\underline{215}$ & $\underline{560}$ & $\underline{0}$ & $\underline{43}$ & 86 \\
\hline & 129 & 344 & 129 & 301 & & 215 & & 344 & 344 & 86 & 43 & 258 \\
\hline *Chaoborus sp. & & & & $\frac{43}{43}$ & $\frac{215}{301}$ & & $\frac{603}{861}$ & & & $\frac{86}{86}$ & & \\
\hline \multicolumn{13}{|l|}{ Ephemeroptera } \\
\hline Caenidae & & $\frac{43}{0}$ & & & & & & & & & & \\
\hline \multicolumn{13}{|l|}{ Hemiptera } \\
\hline ^Notonectidae & & & & $\frac{0}{43}$ & & & & & & & & \\
\hline \multicolumn{13}{|l|}{ GASTROPODA } \\
\hline \multicolumn{13}{|l|}{ PuImonata } \\
\hline Physidae & + & + & & & & & & & & & & \\
\hline Planorbidae & + & & & & & & & & & & + & \\
\hline \multicolumn{13}{|l|}{ Prosobranchia } \\
\hline Valvatidae & + & + & & & & + & & & & + & & + \\
\hline \multicolumn{13}{|l|}{ PELECYPODA } \\
\hline Sphaeriidae & + & & & & & + & & & & & & + \\
\hline \multicolumn{13}{|l|}{ OLIGOCHAETA } \\
\hline Tubificidae & + & & + & & & + & & + & & & & + \\
\hline \multicolumn{13}{|l|}{ HYDROZOA } \\
\hline Hydra sp. & & & & & & $\frac{172}{603}$ & & & & & & \\
\hline
\end{tabular}

1. Where two numbers appear, the numerator is the first sample and the denominator is the second sample.

2. + denotes presence in sarmle.

3. * means not benthic but found in sample as indicated. 
Appendix 3d-Benthic macroinvertebrate count, Delavan Lake, September 26, 1985.

[units in organisms per square meter]

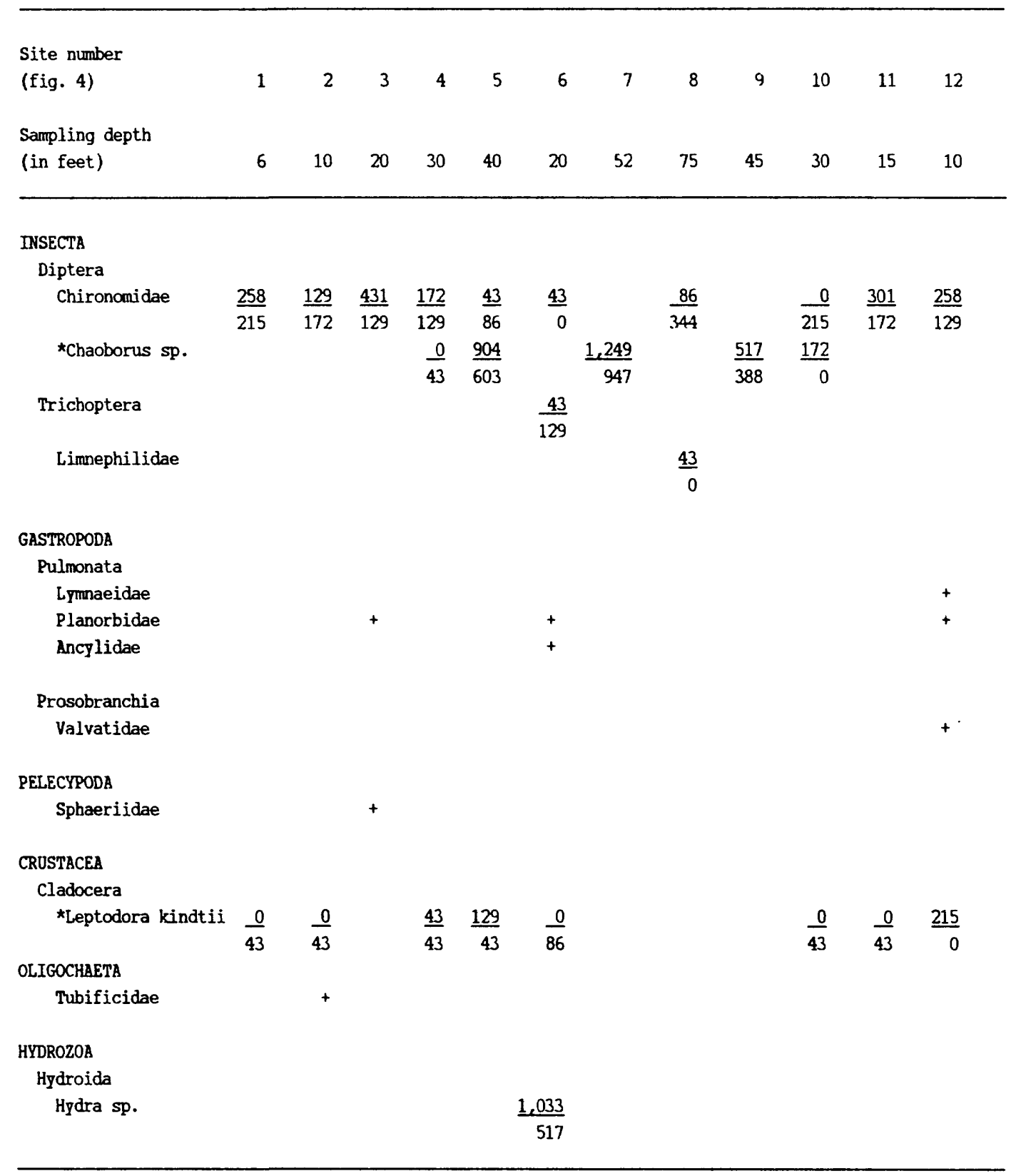

1. Where two numbers appear, the numerator is the first sample and the denominator is the second sample.

2. + denotes presence in sample.

3. * means not benthic but found in sample as indicated. 


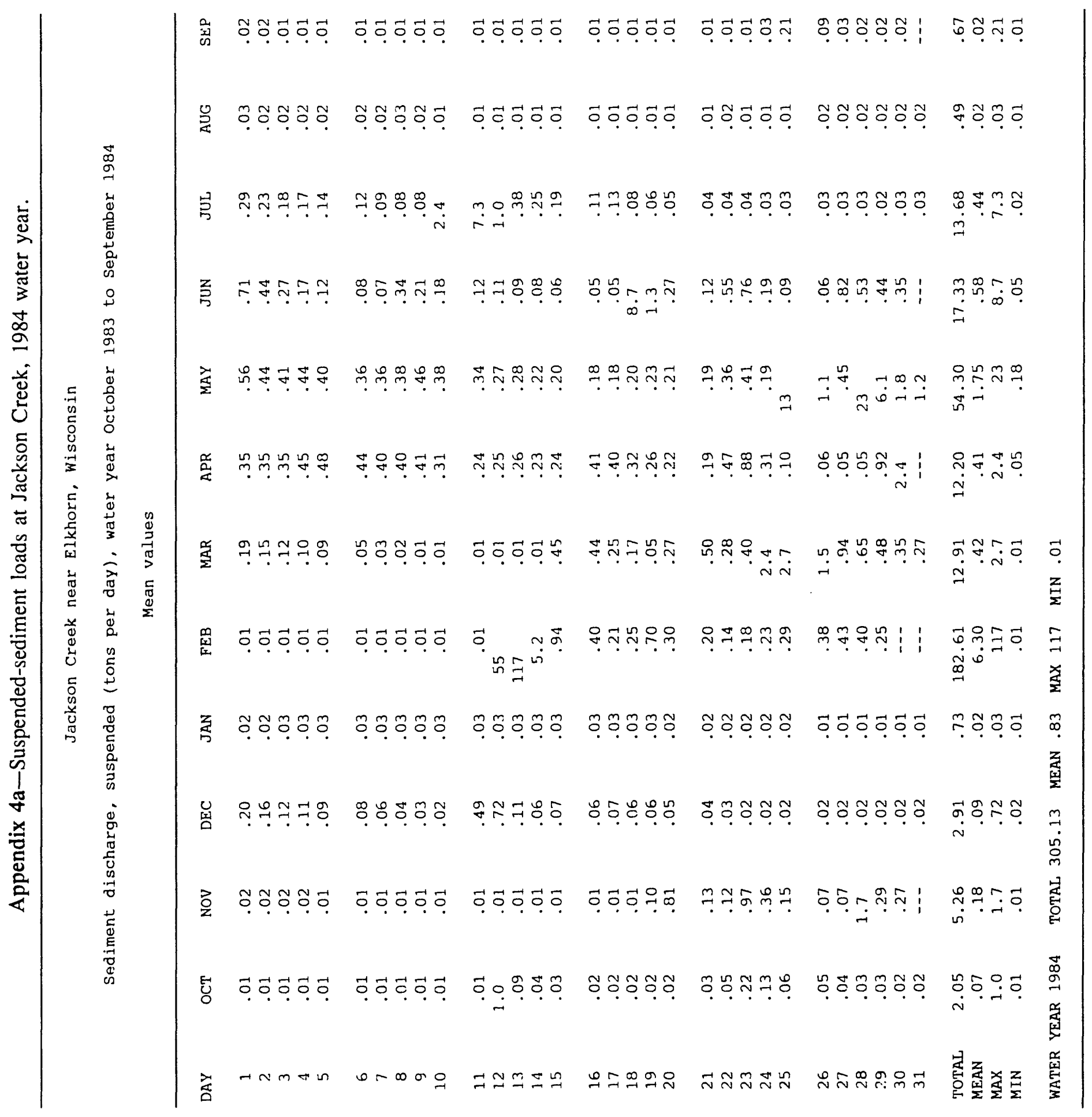




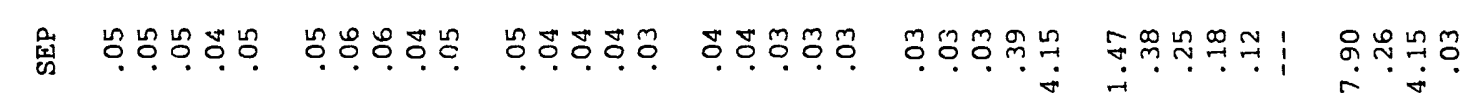

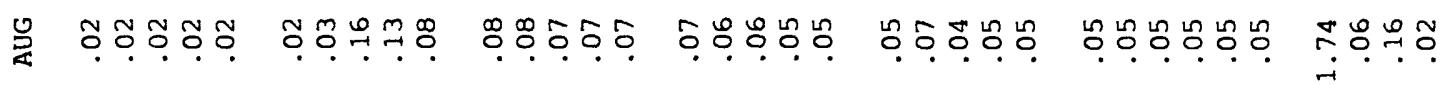

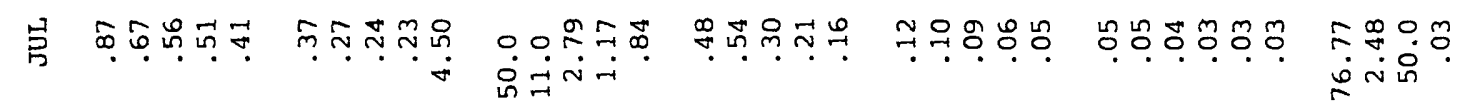
z. 网 商

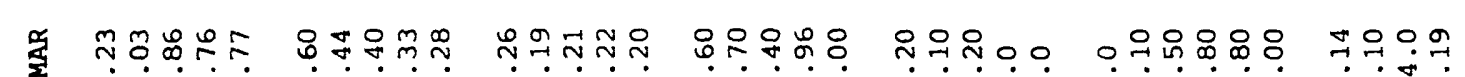

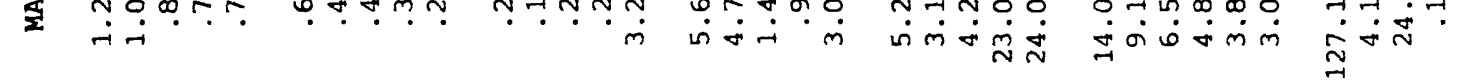

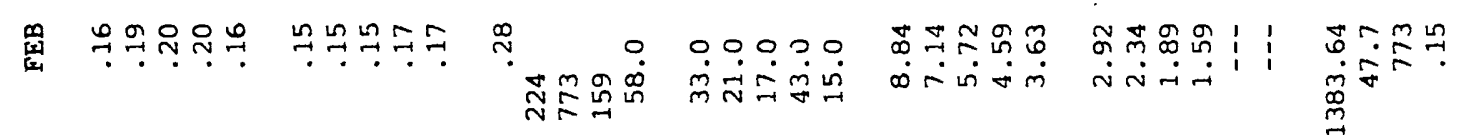
在 若

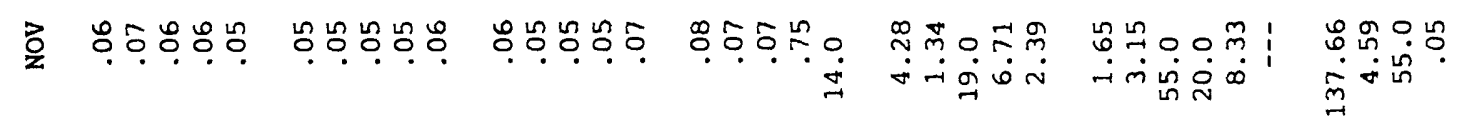

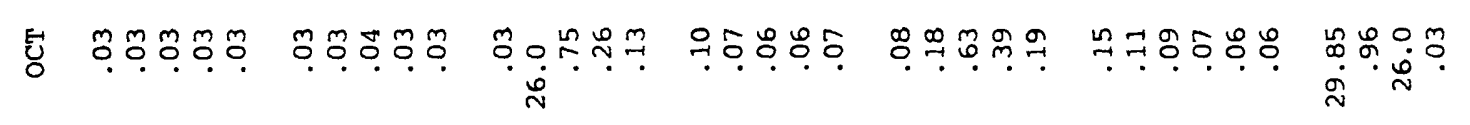

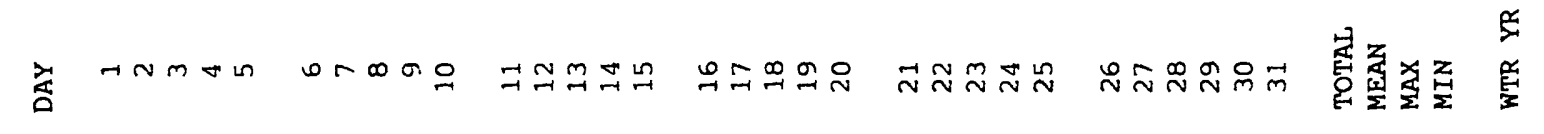




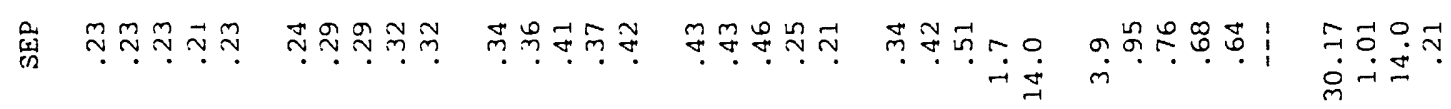

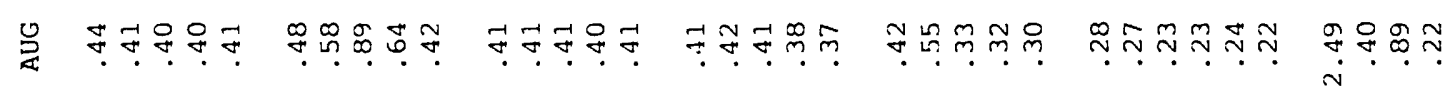

弱

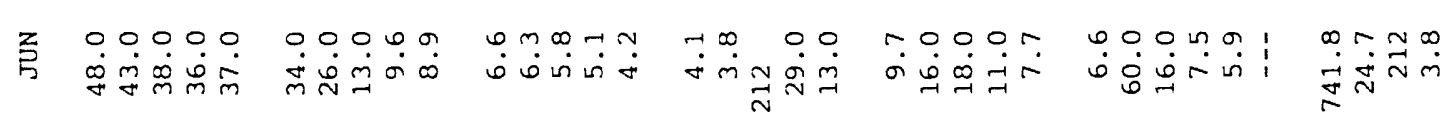

专

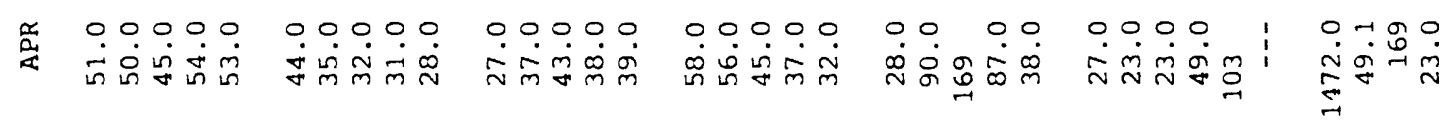

岁

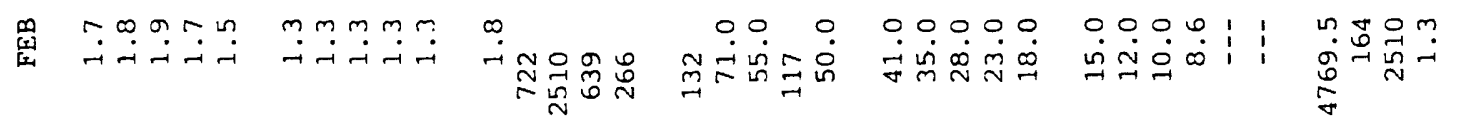

द

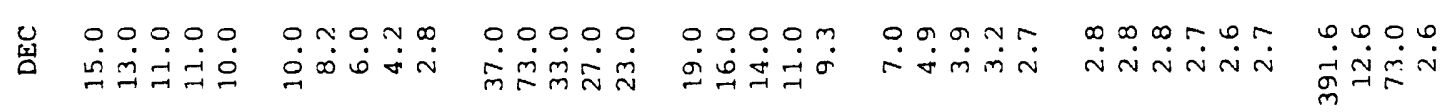

ठ

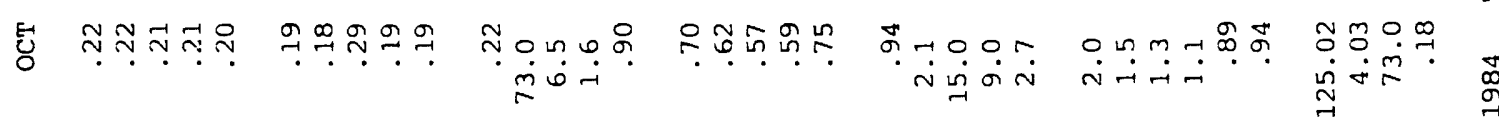

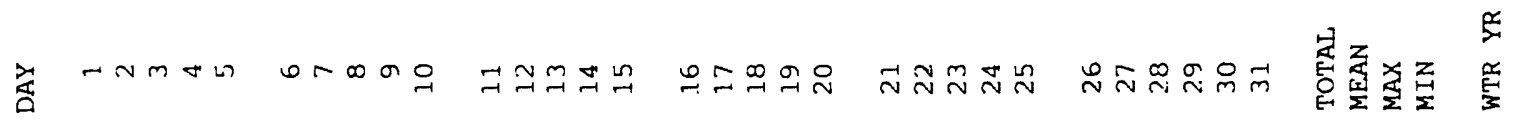




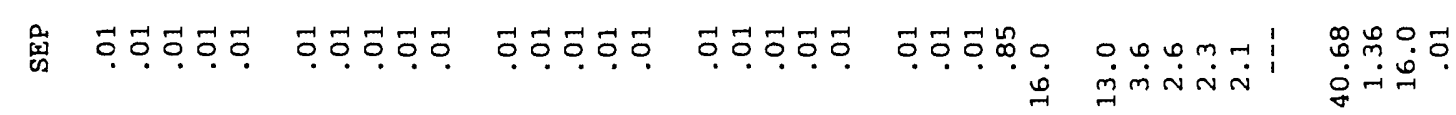

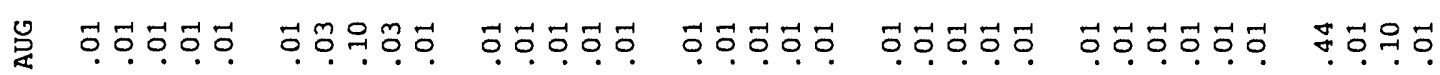

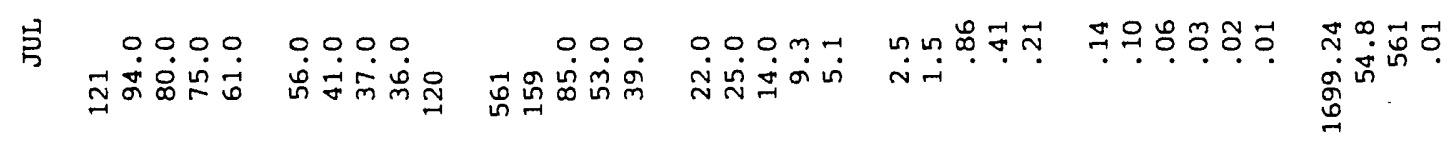

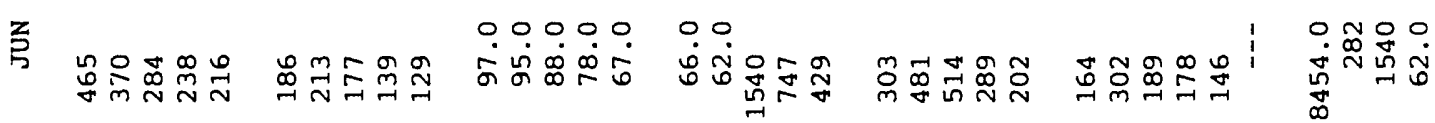

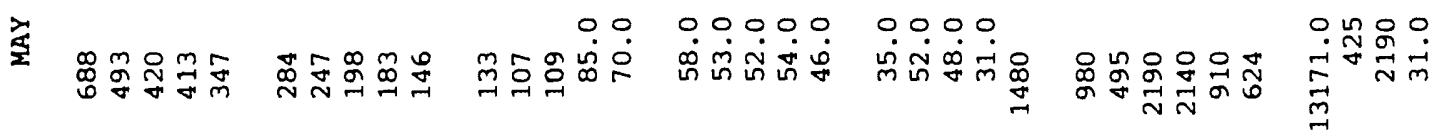

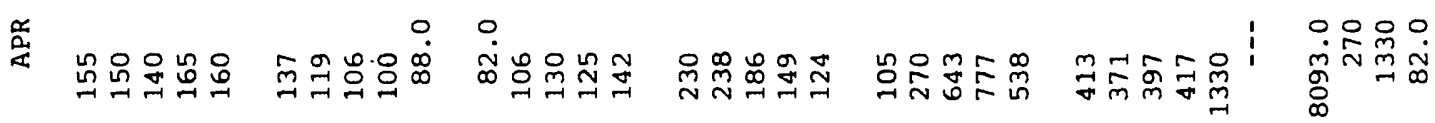

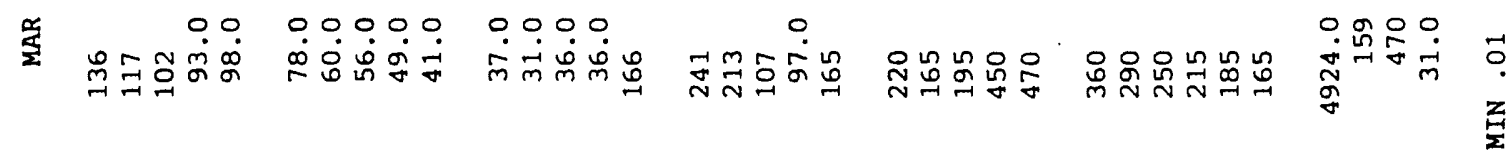

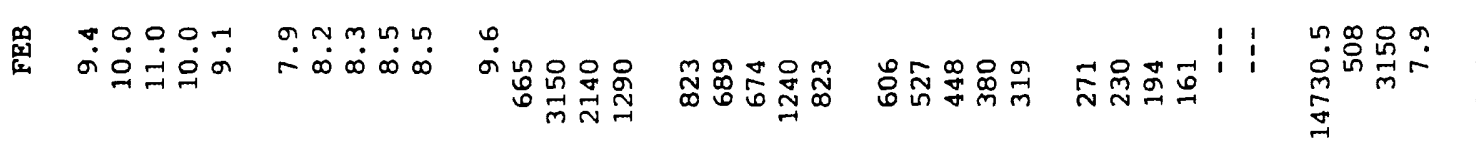
Z ऽ

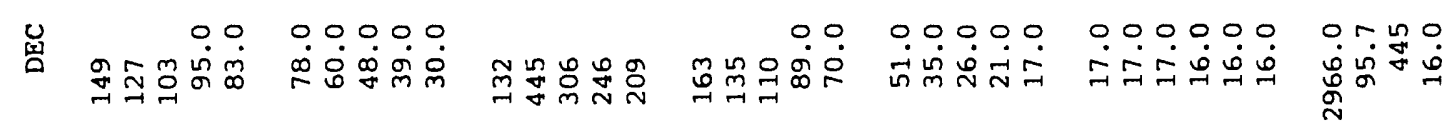

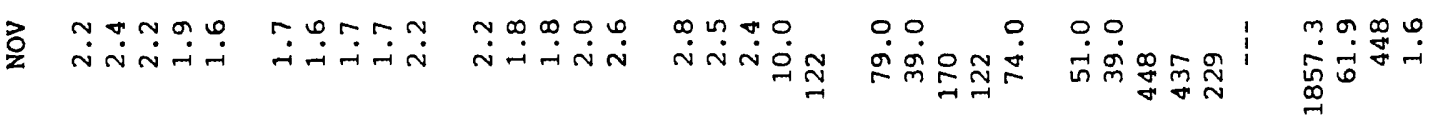

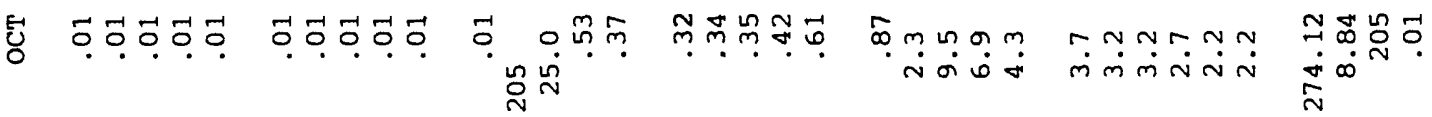

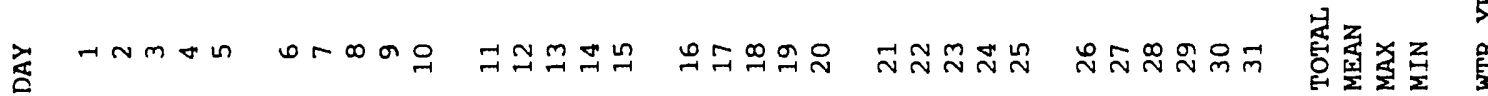


重

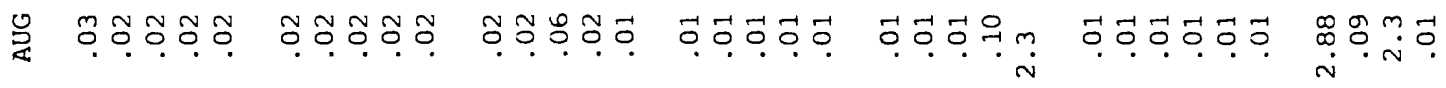

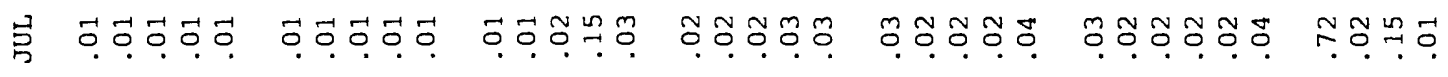

द

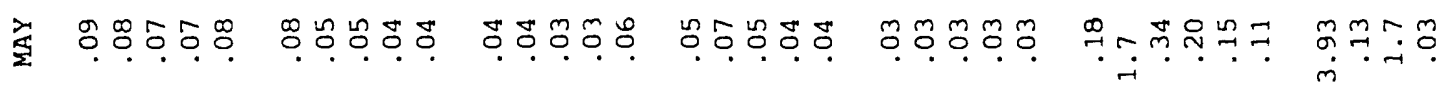

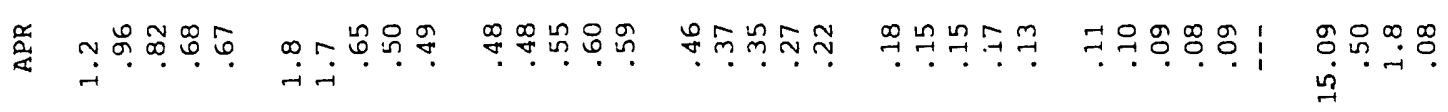

产

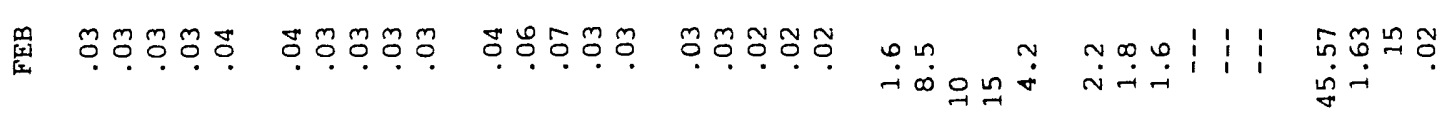

क़े.

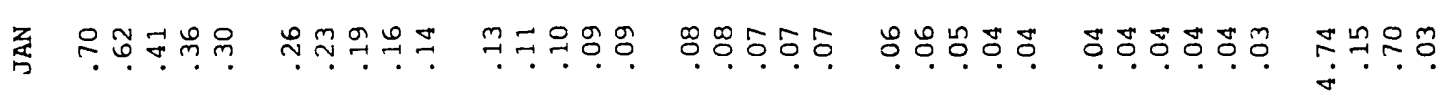

空㲾

$\underset{\sim}{\approx}$

齐

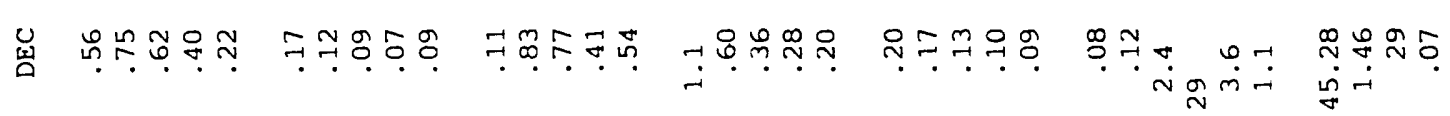

운요

焉要

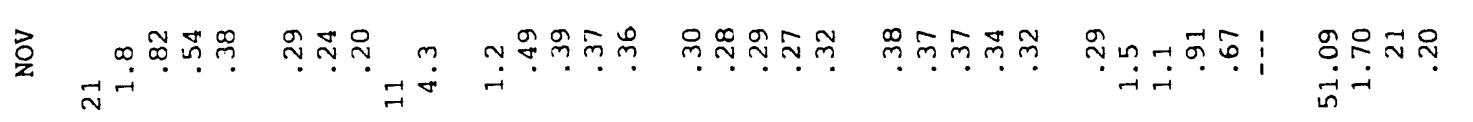

mㄷำ

ํำ

晨朂

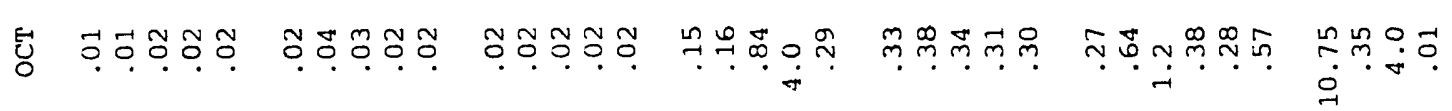

芯

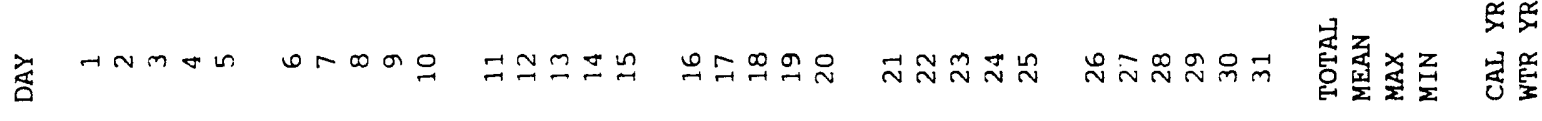




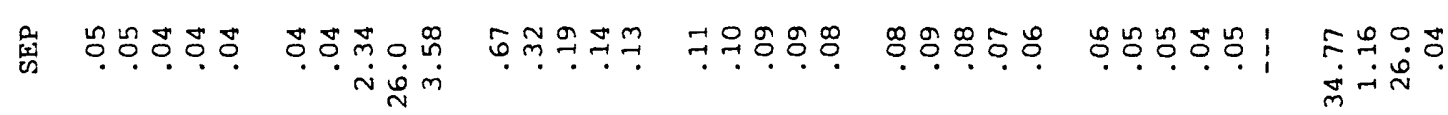

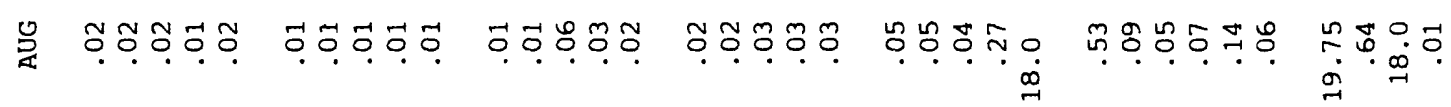

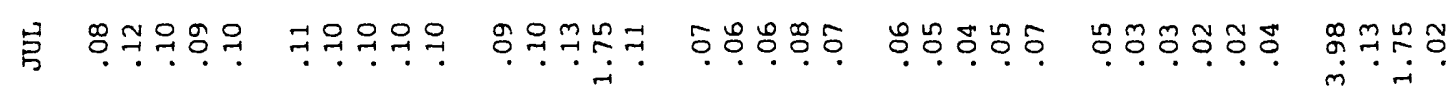

z

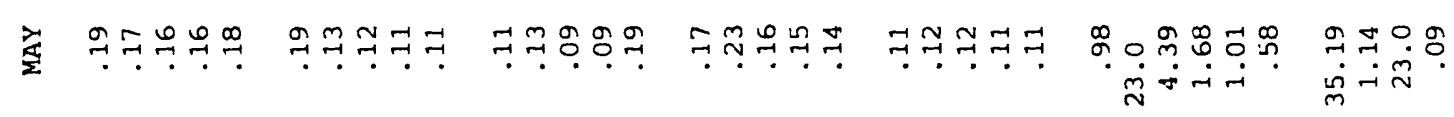

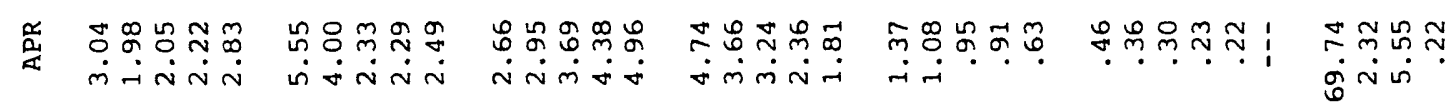

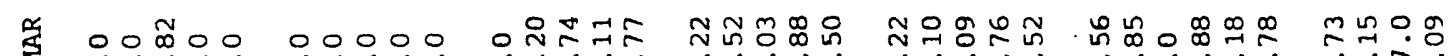

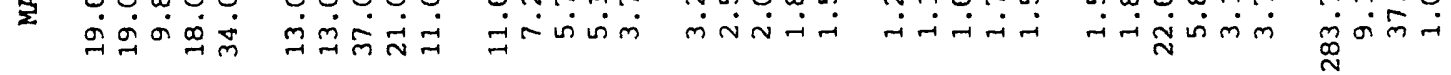

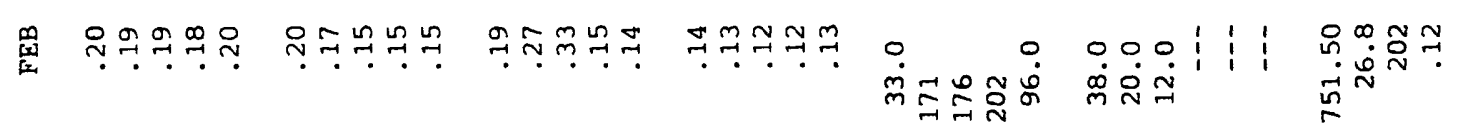

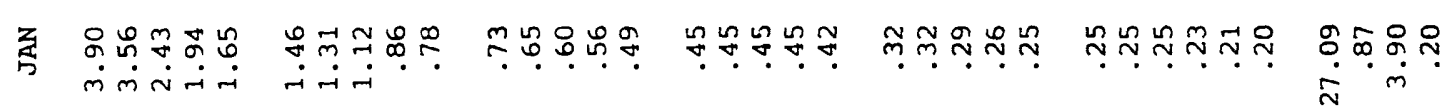

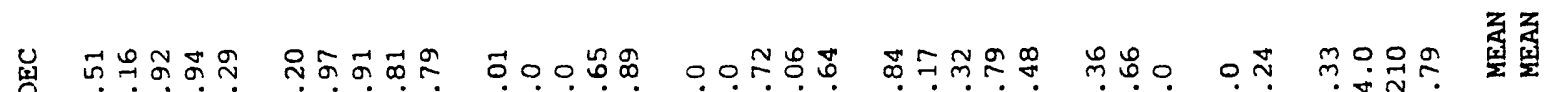

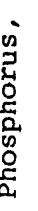

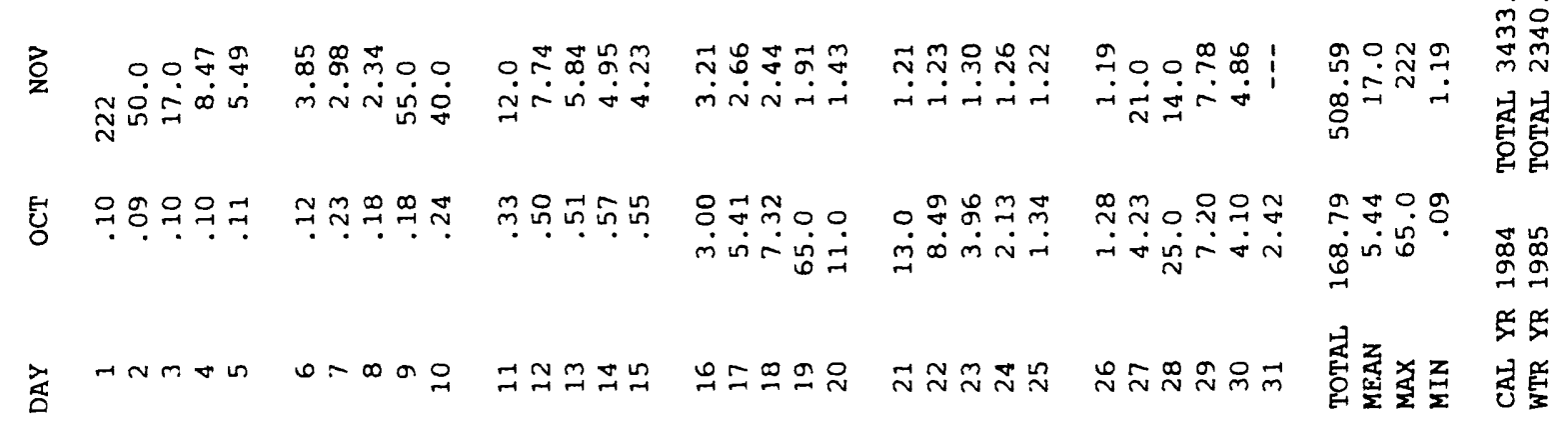




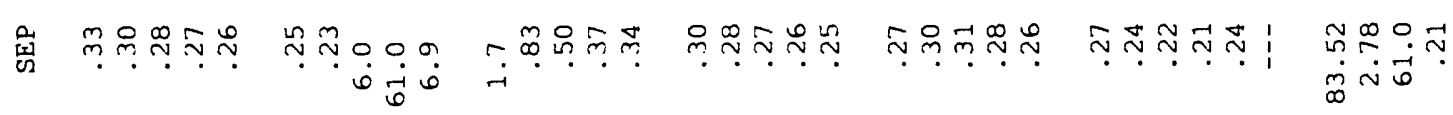

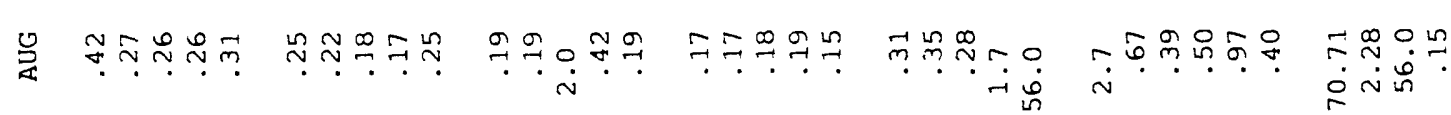

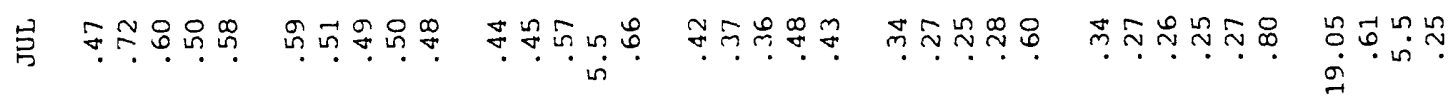

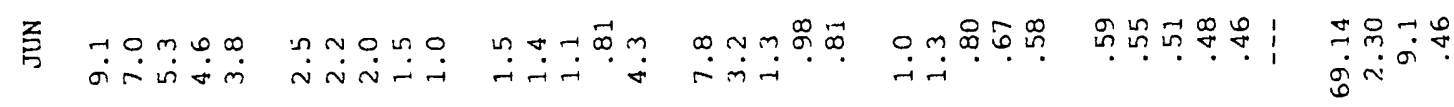

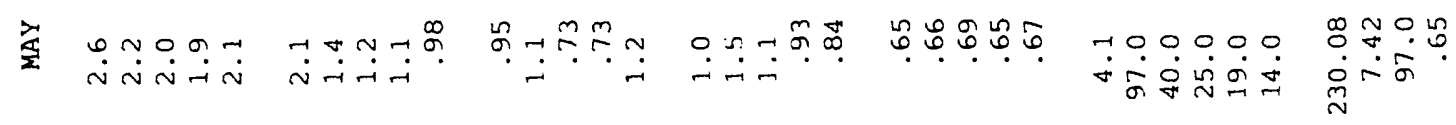

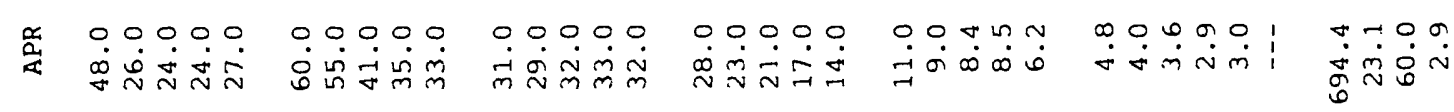

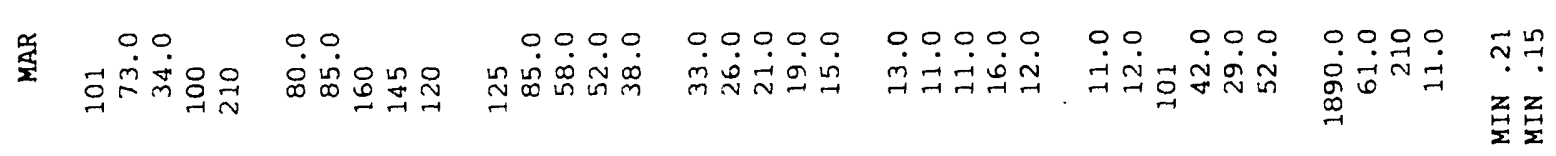
䚀

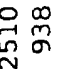
在空

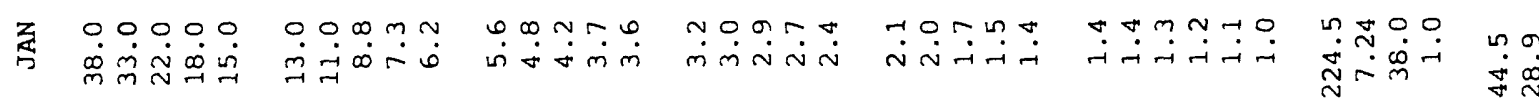

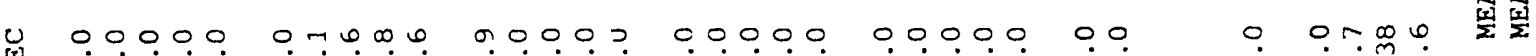

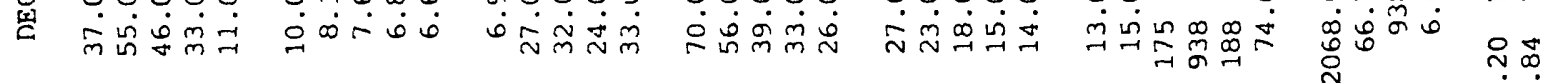

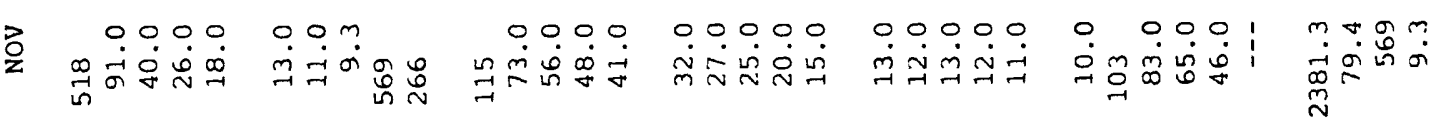

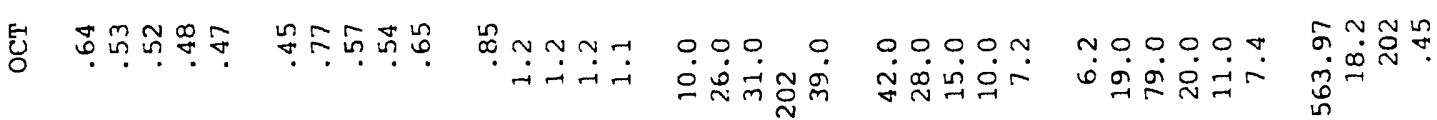

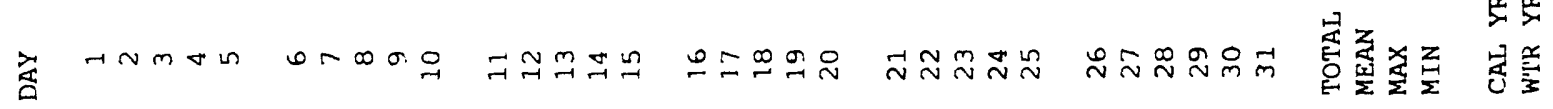




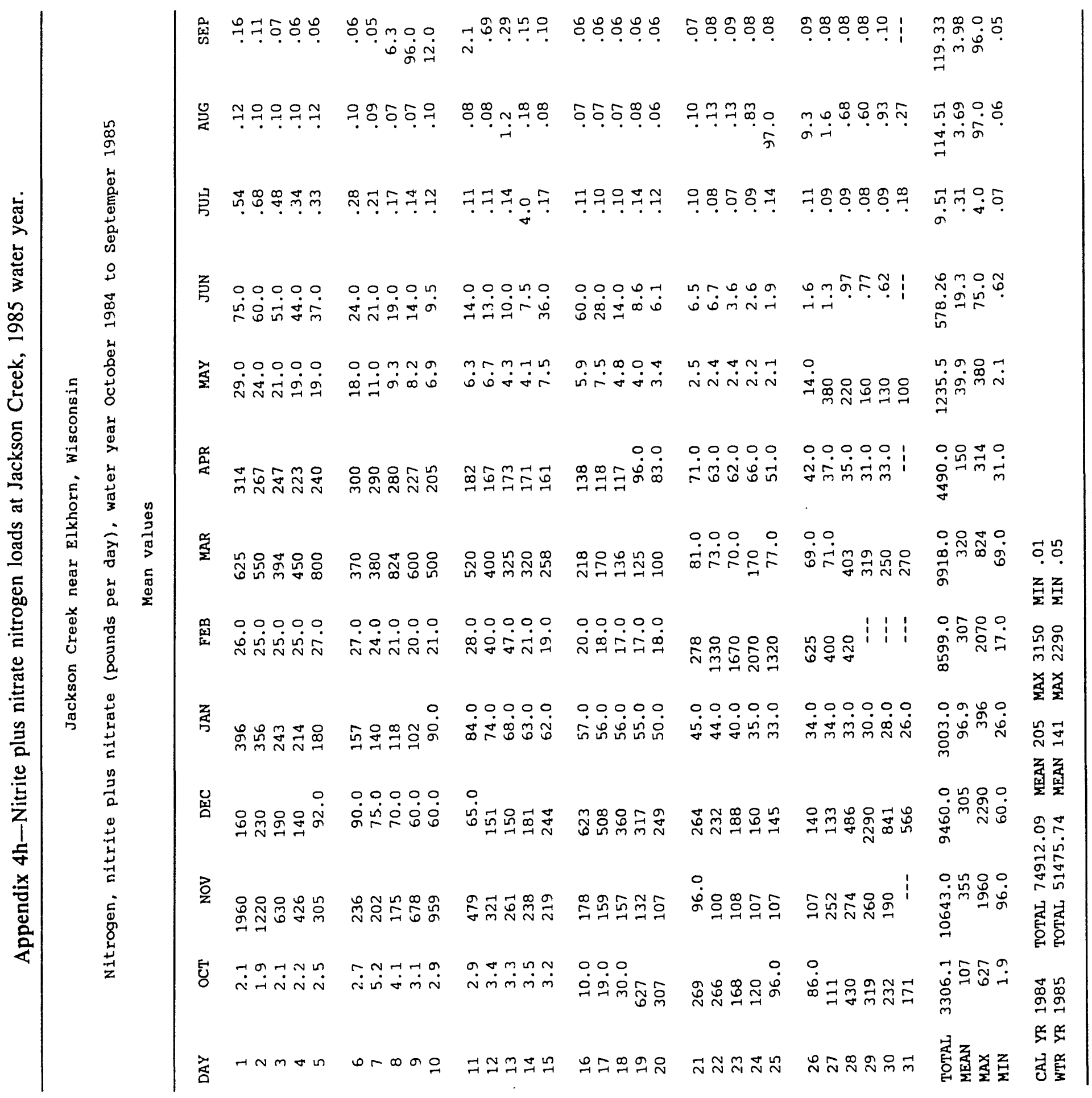




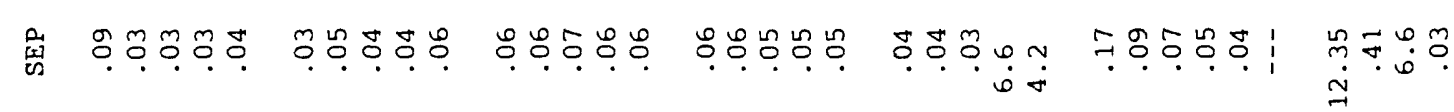

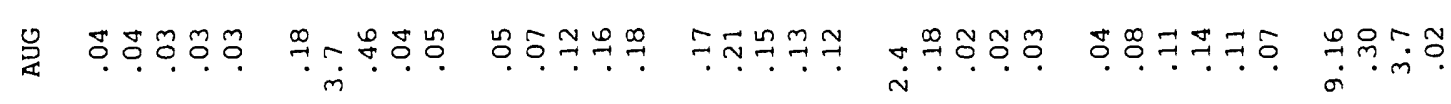

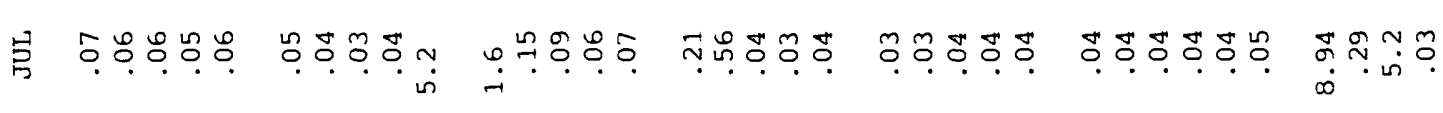

Z

希

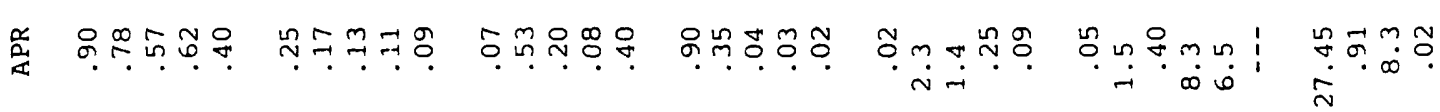

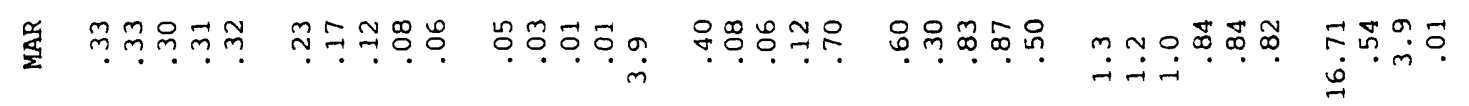

罡

皇

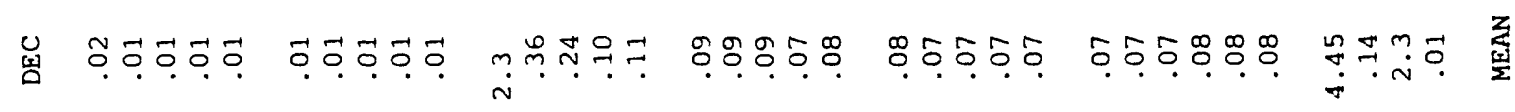

z

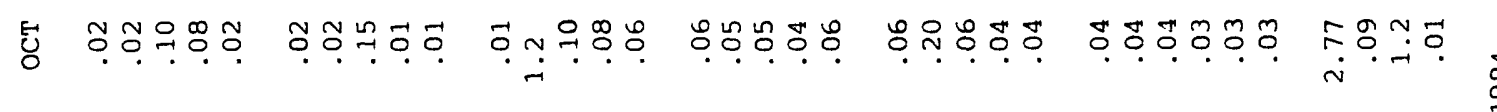

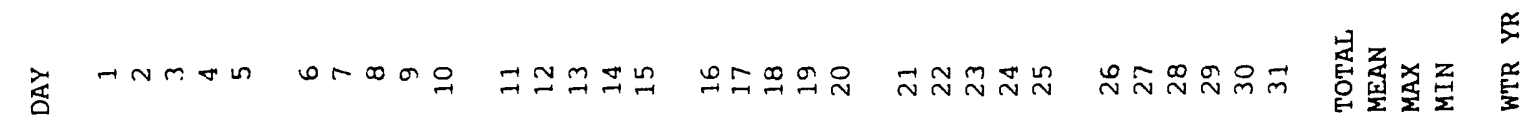




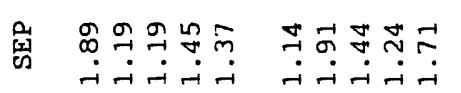

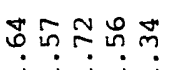

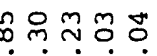

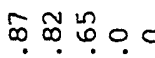

국ำำㅇํㅇำ

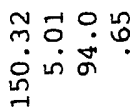

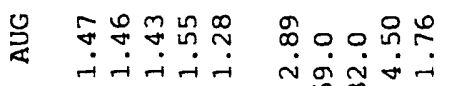

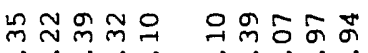

moN

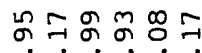

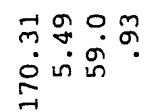

官

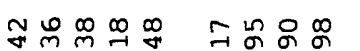

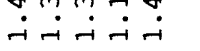
¿. $\stackrel{\sim}{\sim}$

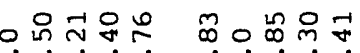

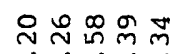

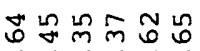

ตำํำ

z

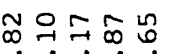

$000 \stackrel{0}{\frac{\pi}{2}} \frac{0}{2}$

กี่ํํㅇํำ

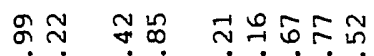

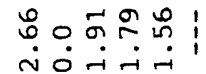

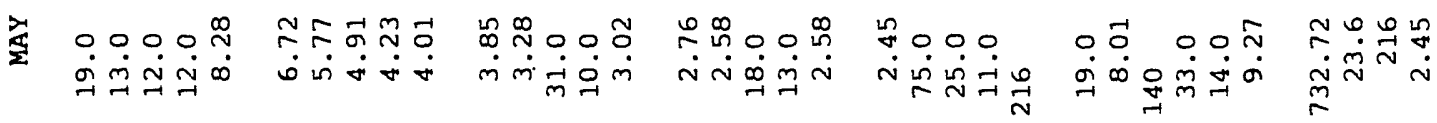

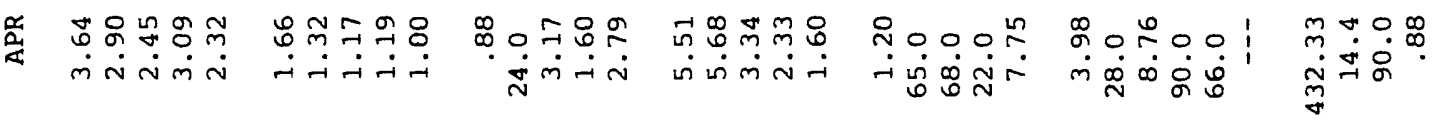

空

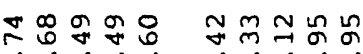

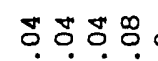

نั

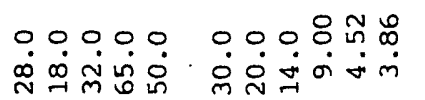

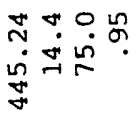

䙓

$\stackrel{?}{7} \div \stackrel{?}{?} \stackrel{\infty}{\infty} \stackrel{\infty}{?}$

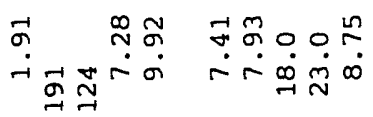

ㅃํㅇำ

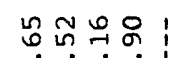

讪

Z्द

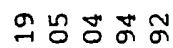

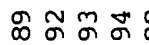

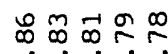

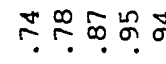

궁ำ 윰ำ

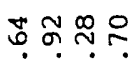
$\stackrel{\infty}{\sim}$

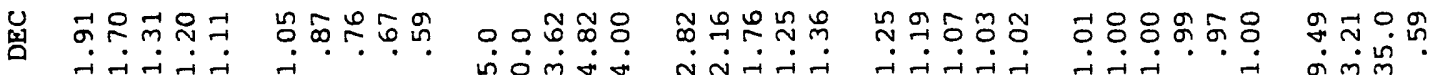
नंन्नु

察

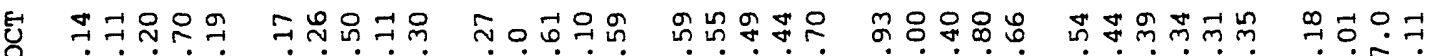

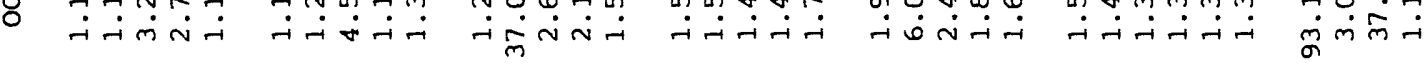

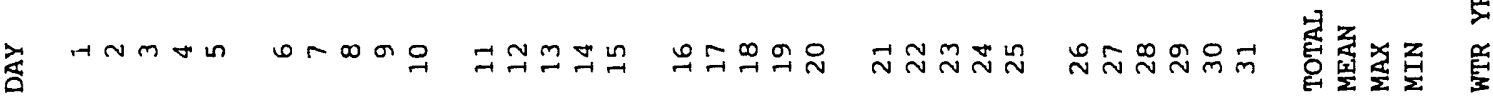


兽

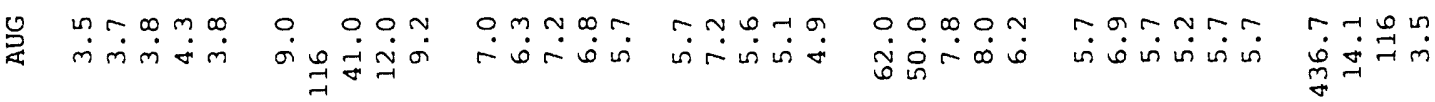

局

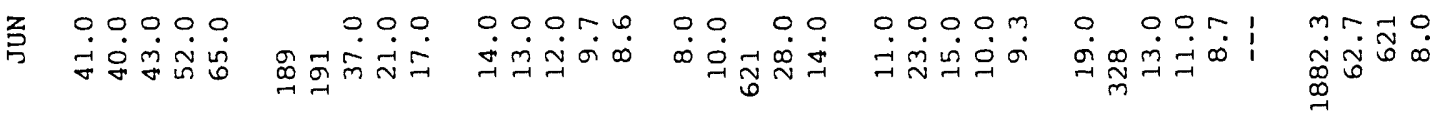

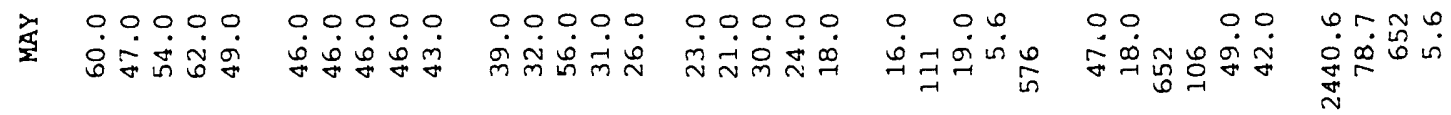

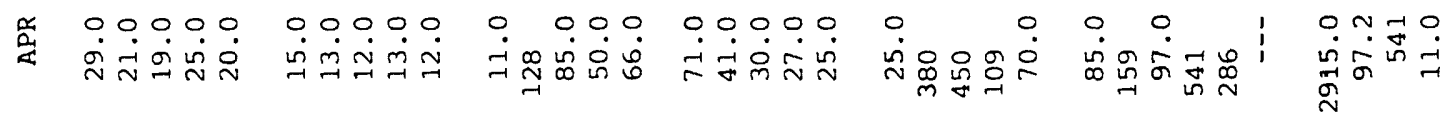

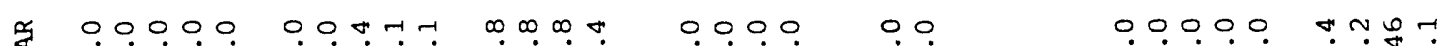

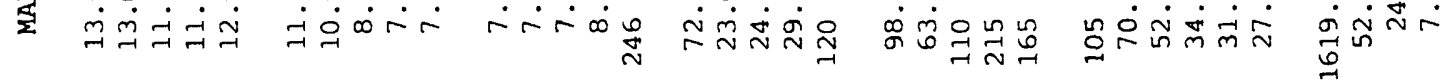

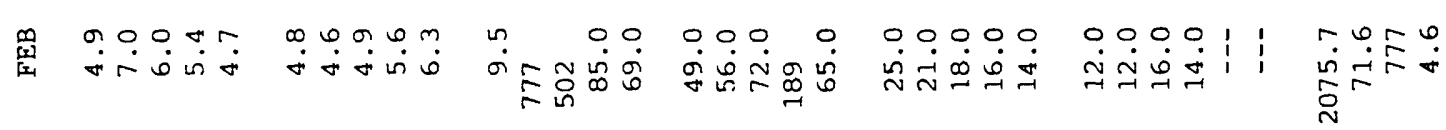

秀

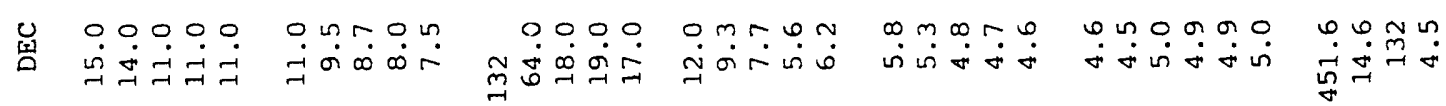

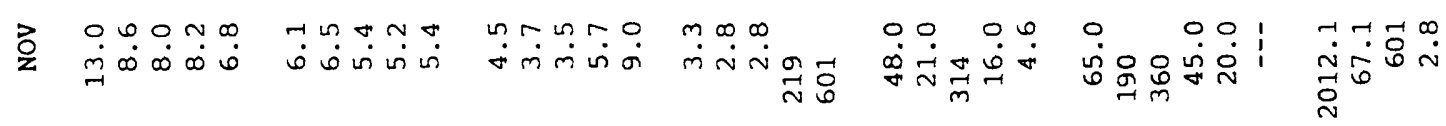

落

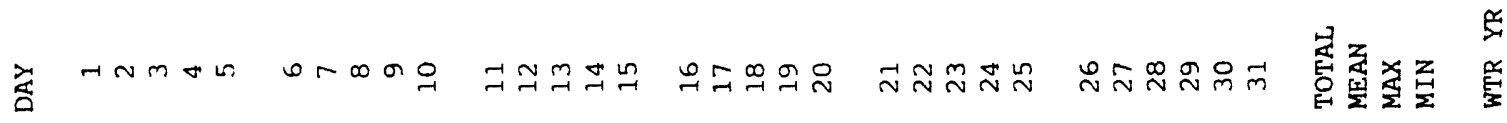




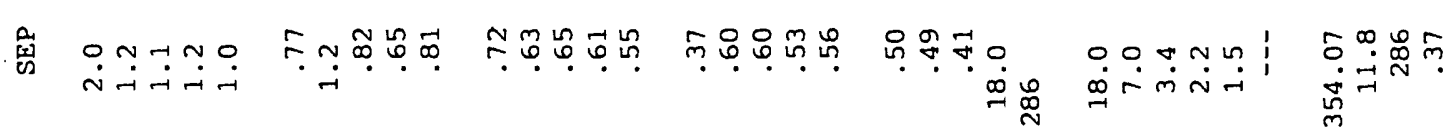

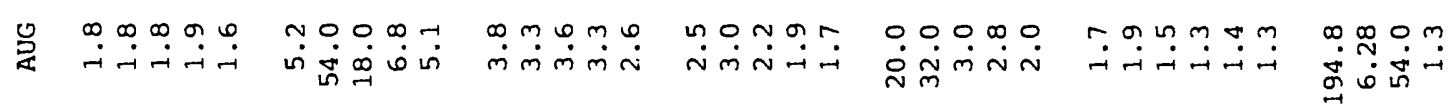

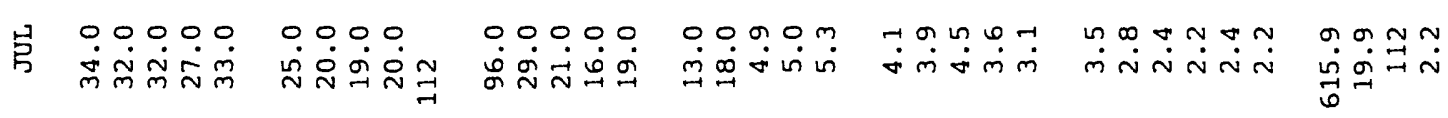

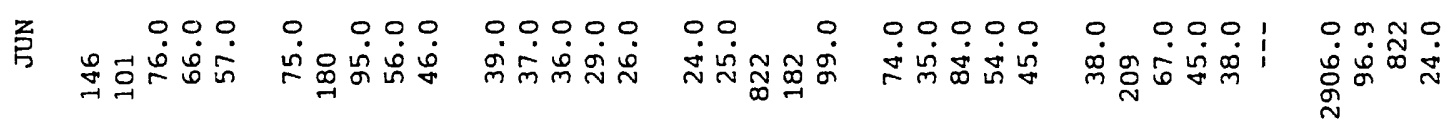

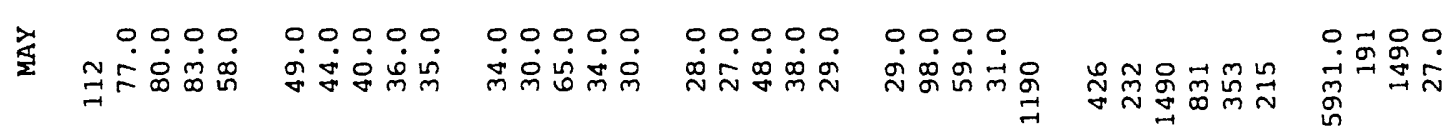

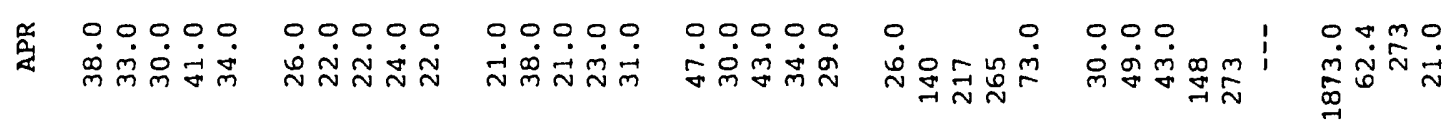

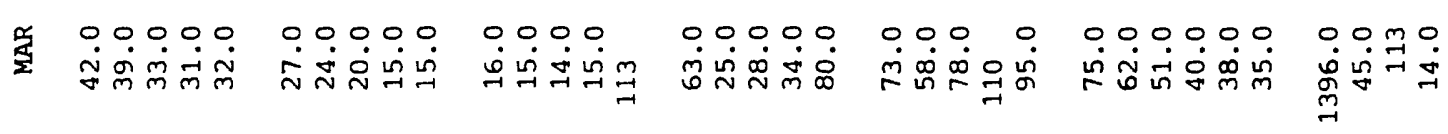

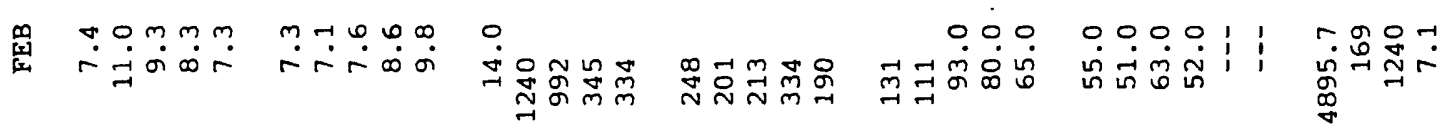

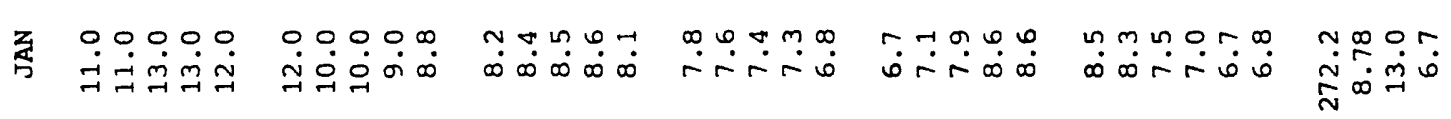

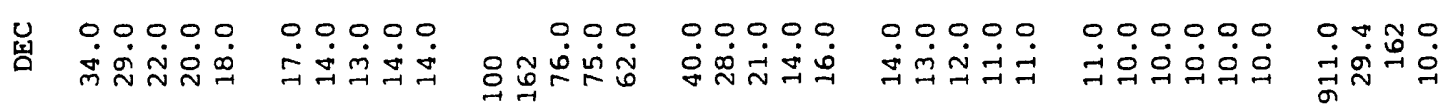

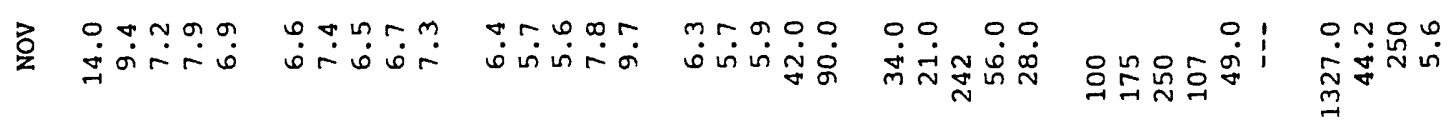

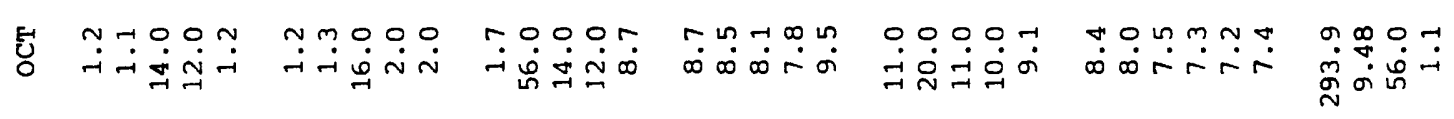

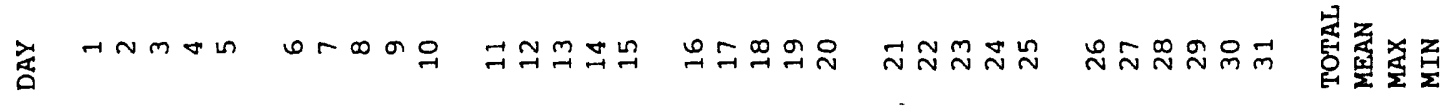




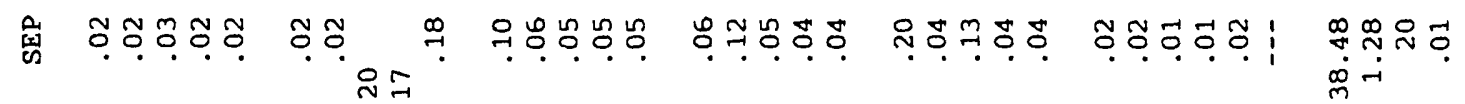

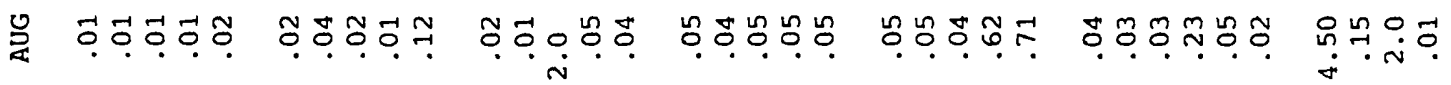

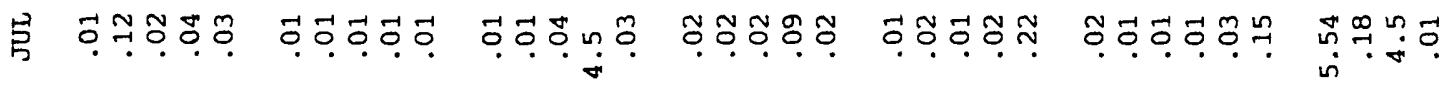

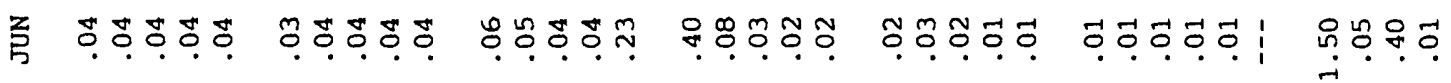

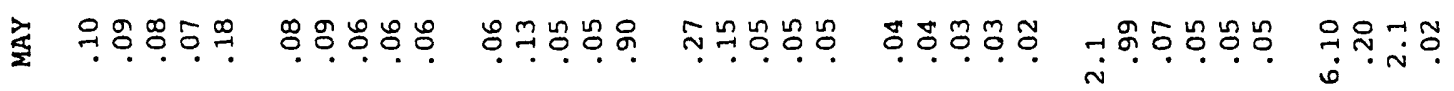

犁

厸

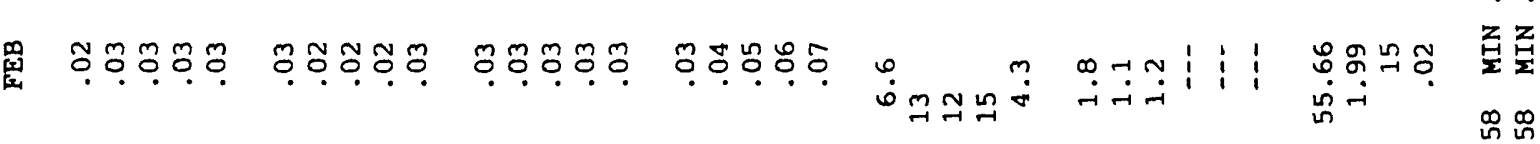

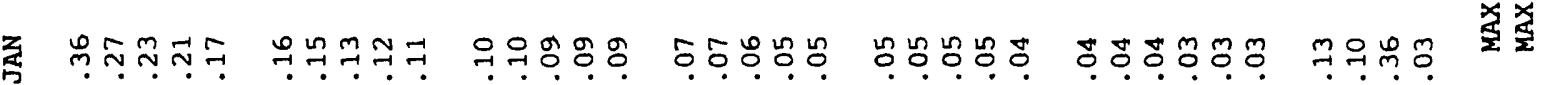
$\because$

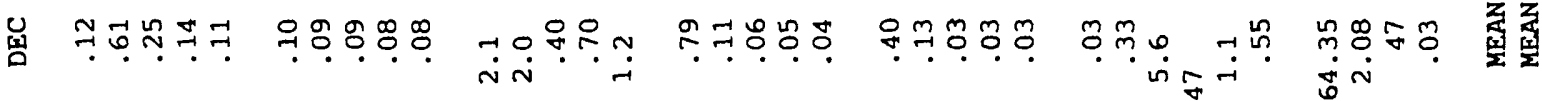

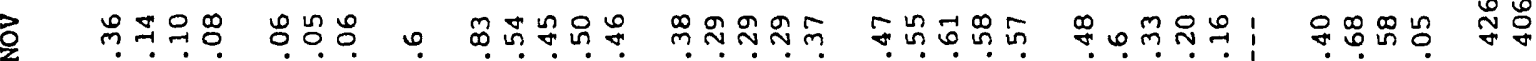
象

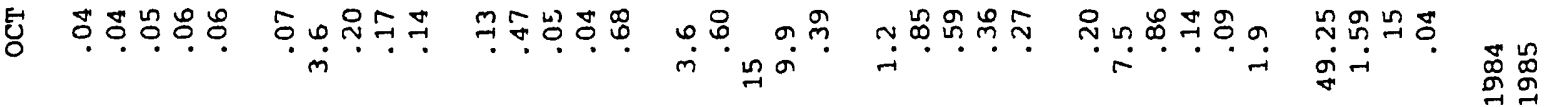

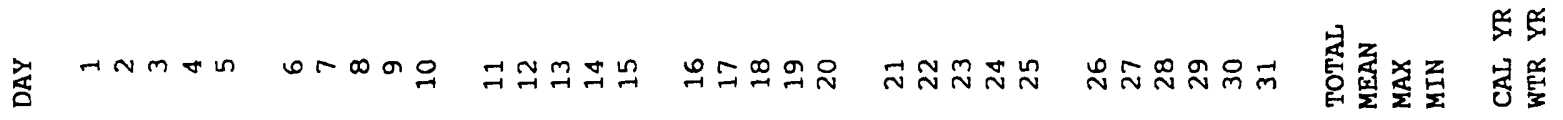




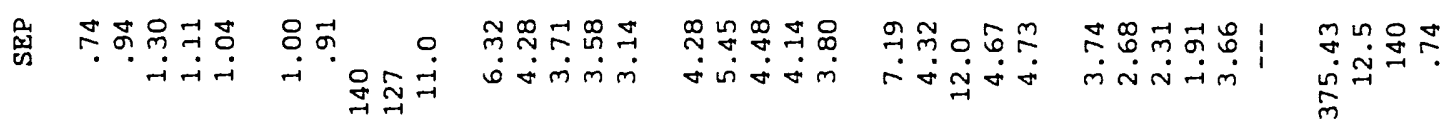

峎

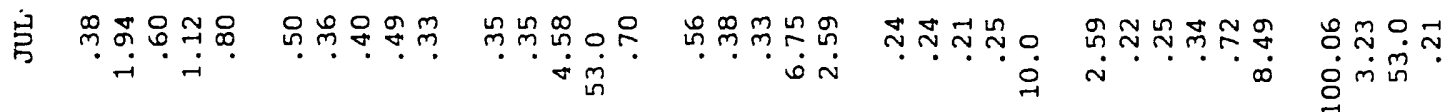

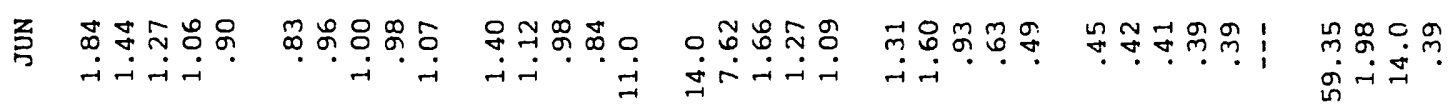

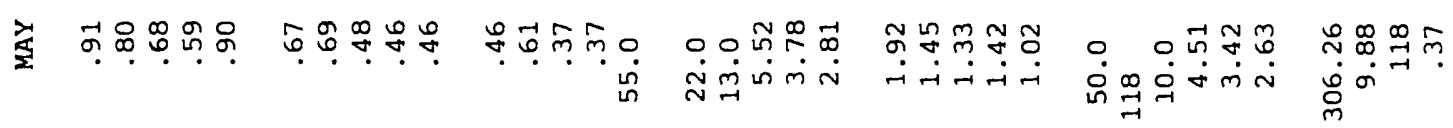

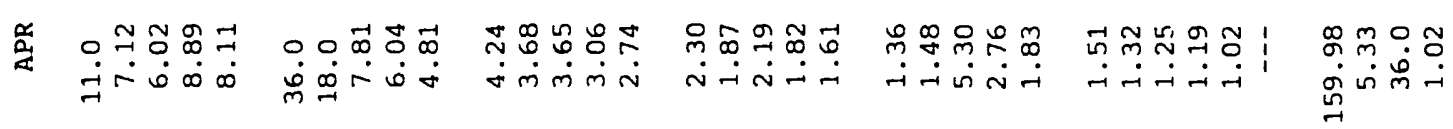

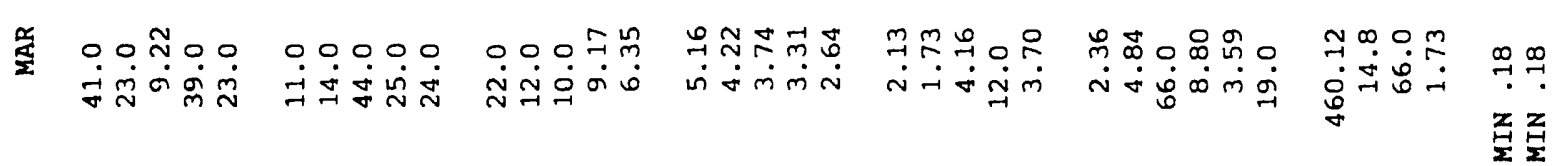

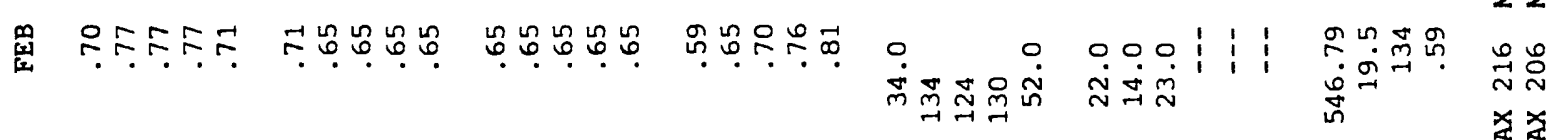

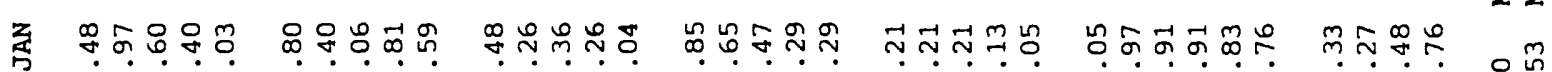

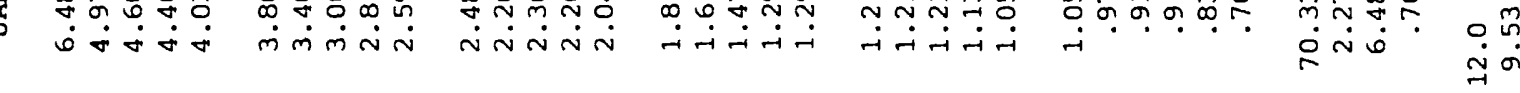

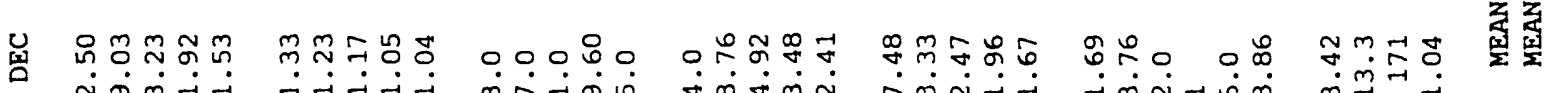

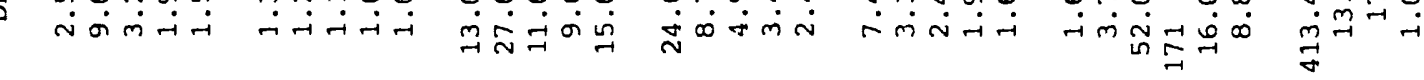

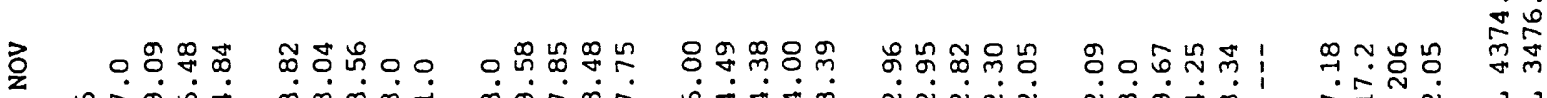

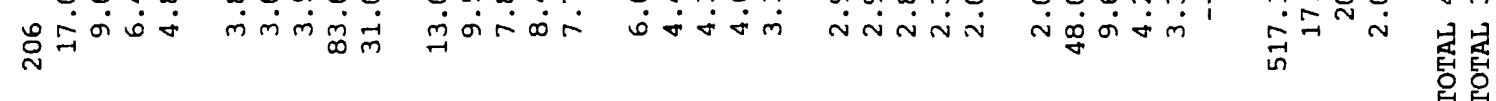

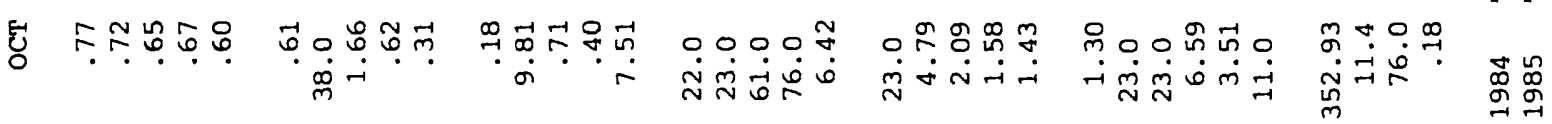

庭 


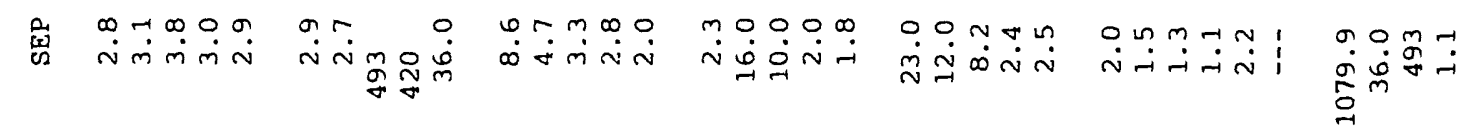

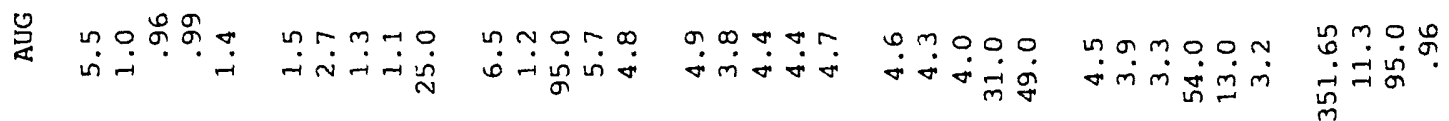

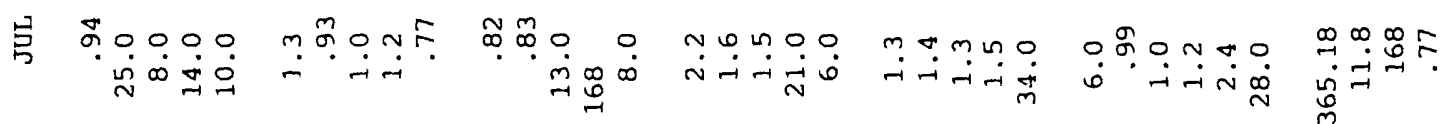

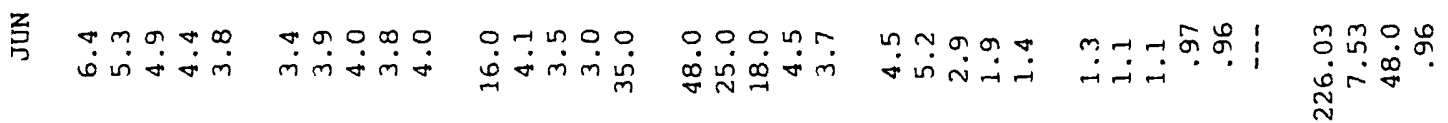

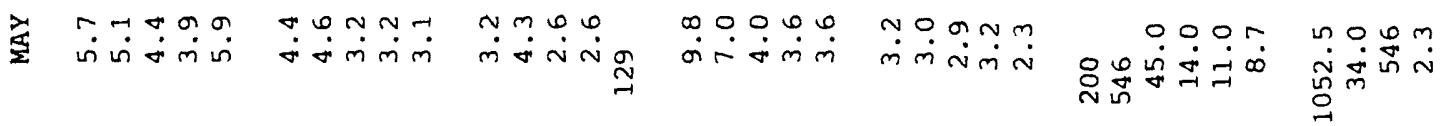

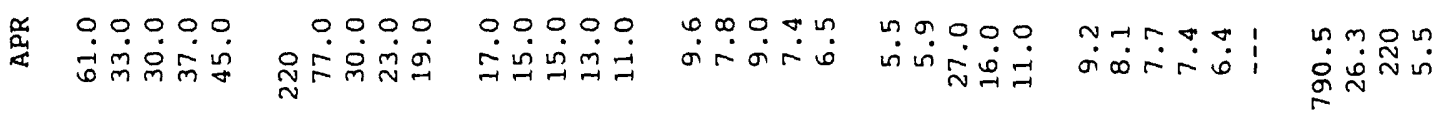

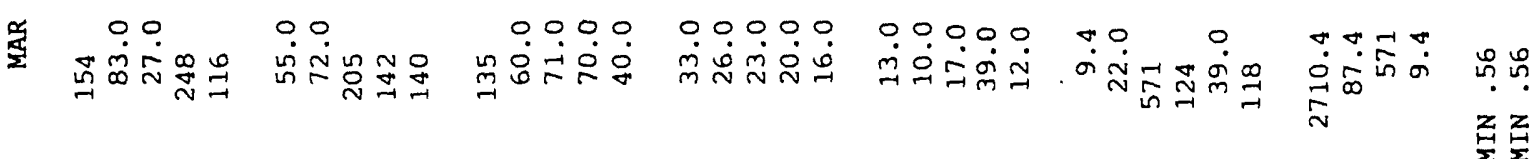

番

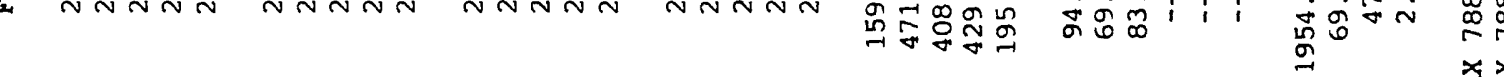

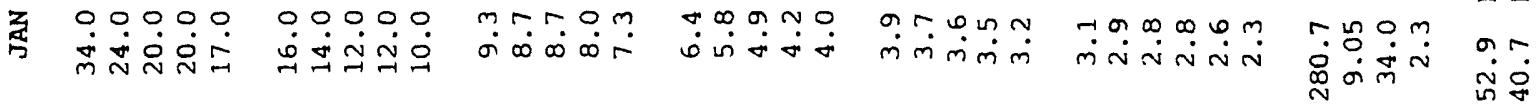

U

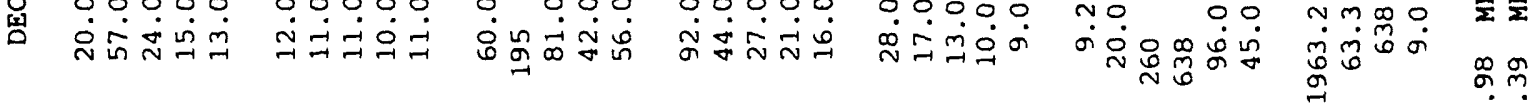

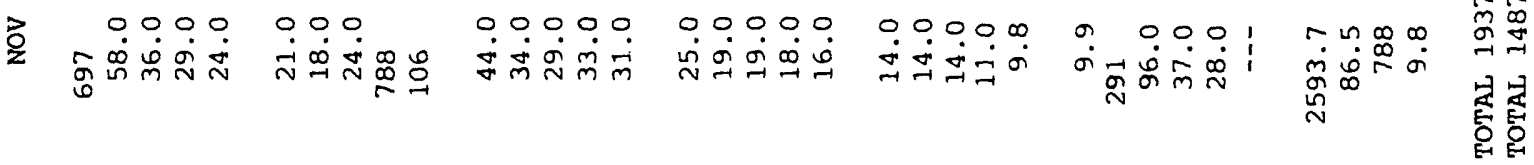

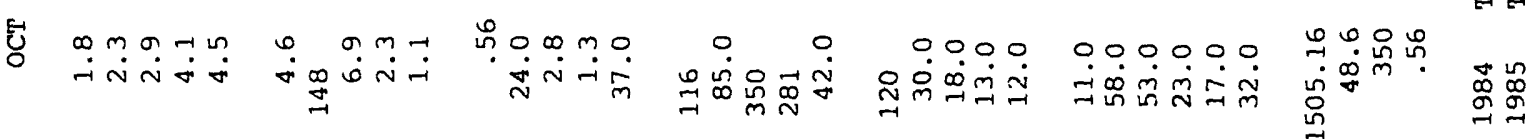

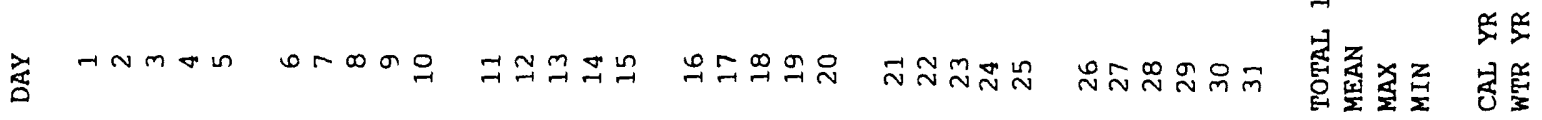




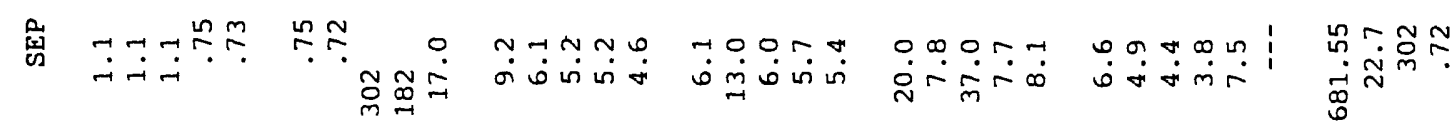

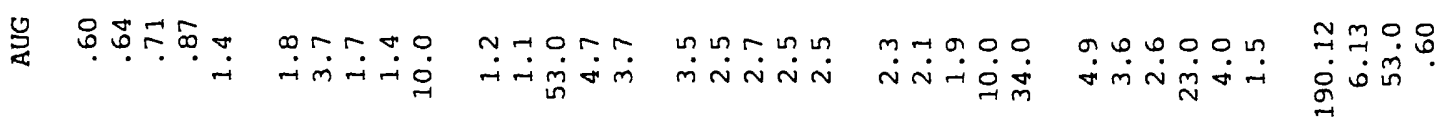

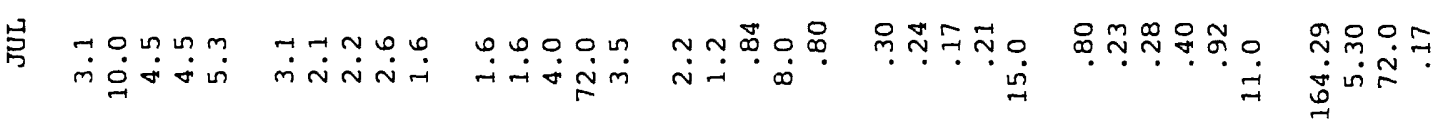

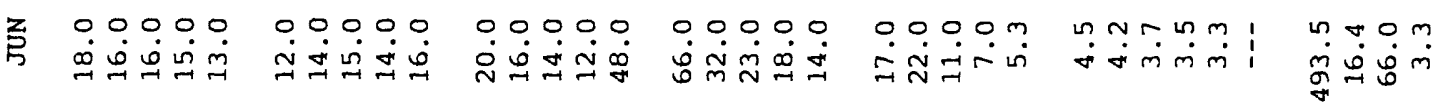

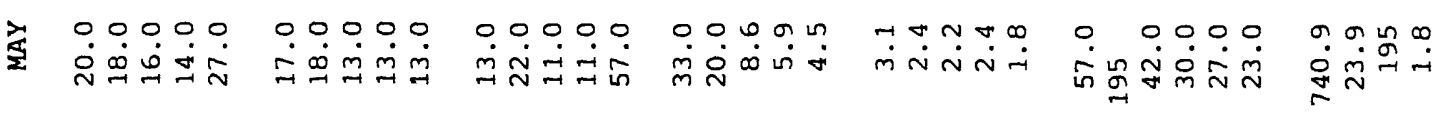

尊

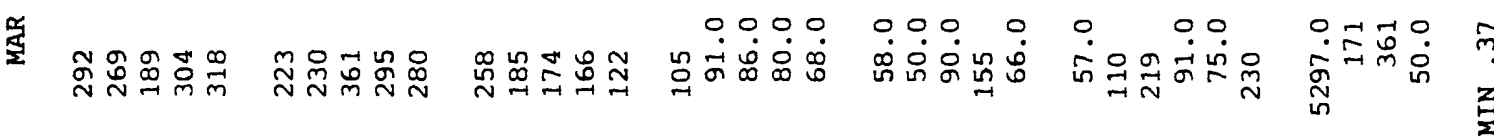

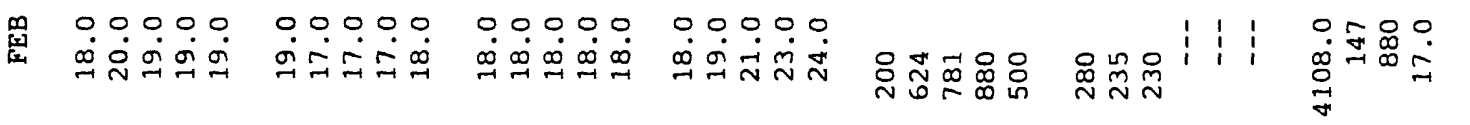

z $00000 \quad 00000 \quad 000000000000000 \quad 000000 \quad 0000$

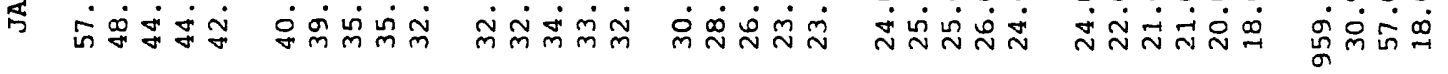

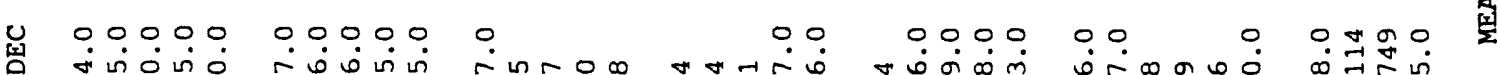

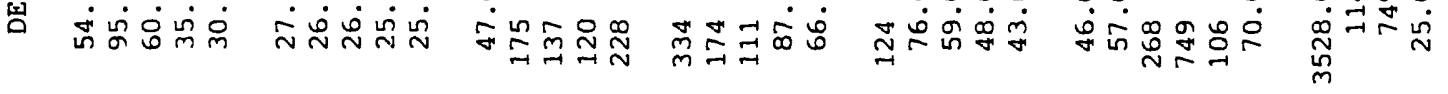

龸

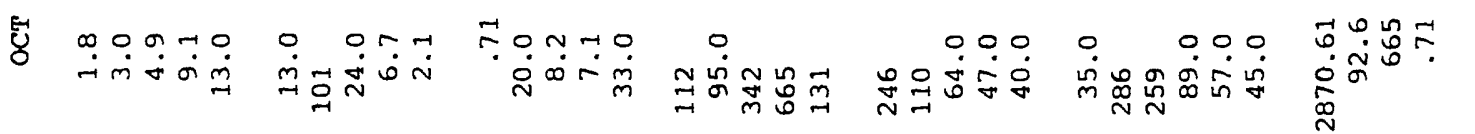

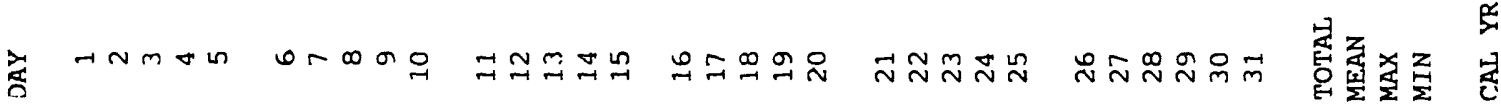




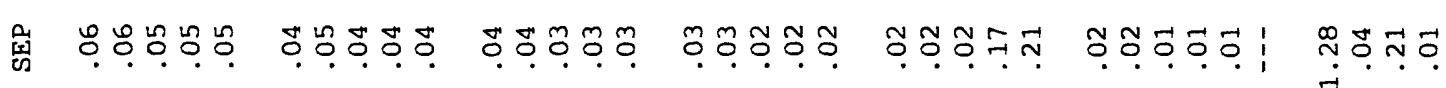

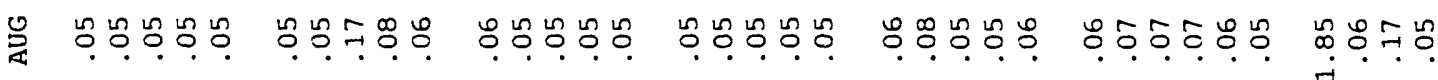

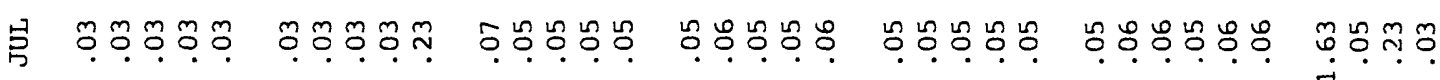
z 承

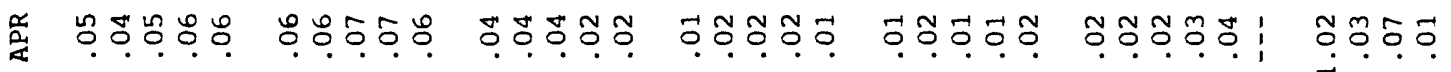

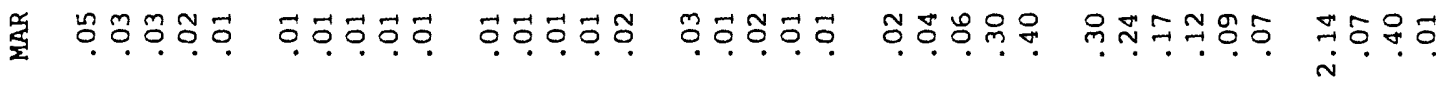

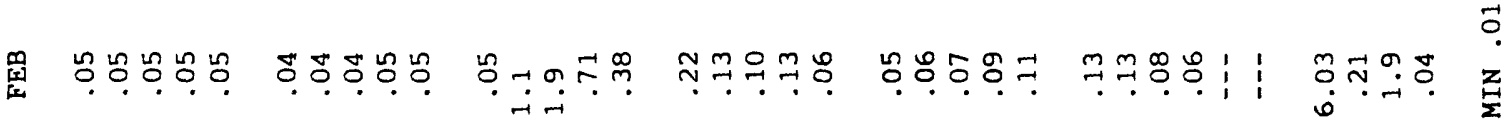

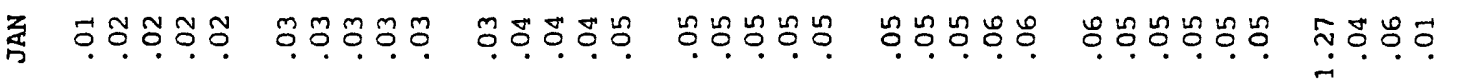

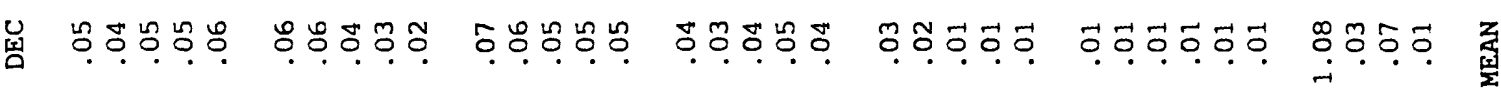

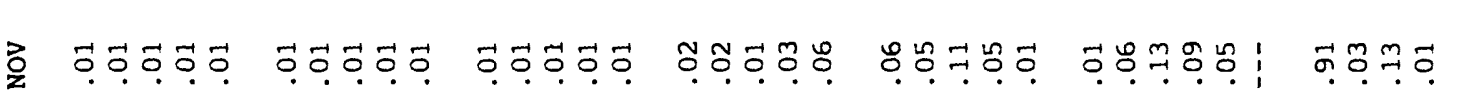
E

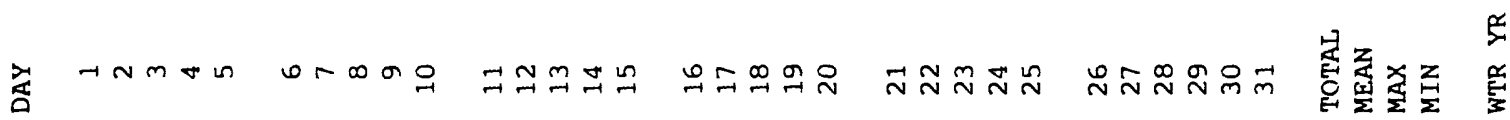


离

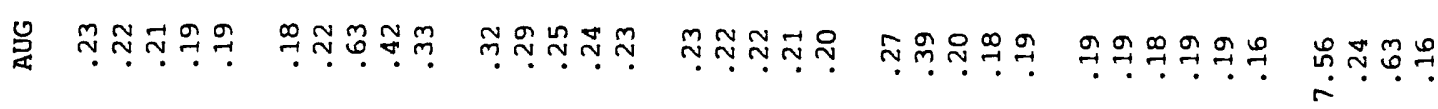

鳬

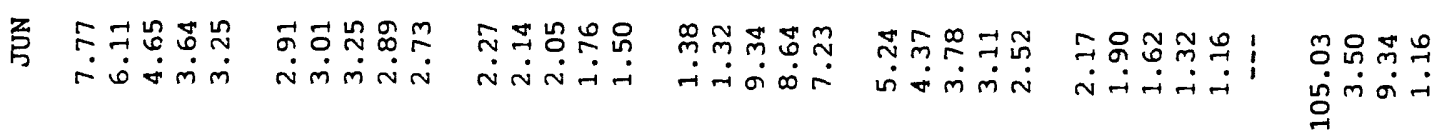

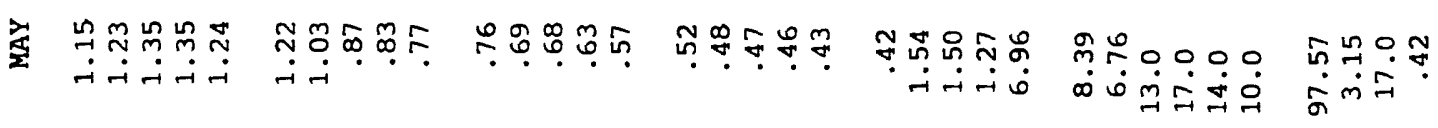

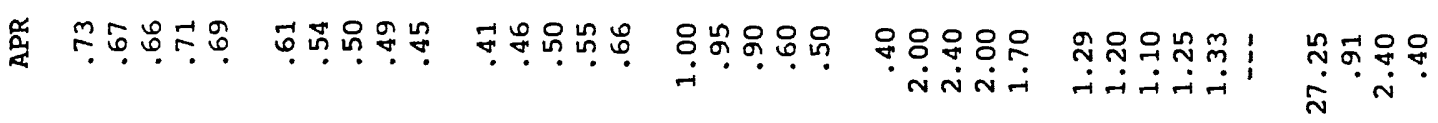

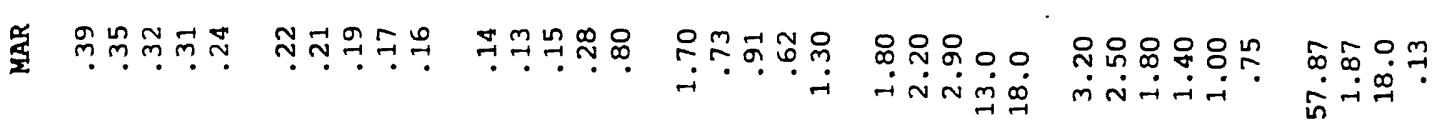

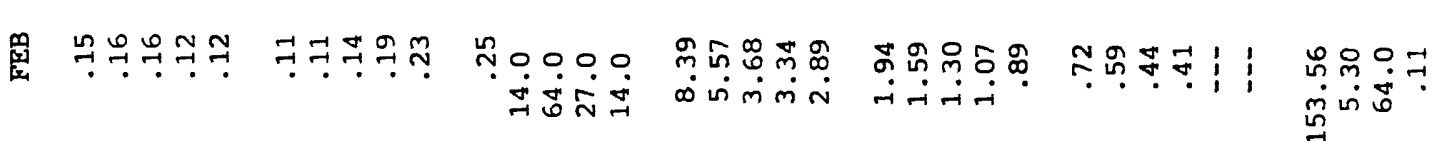

参

茴

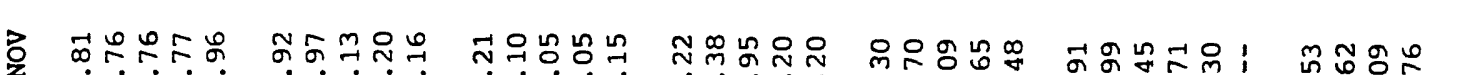
2 क.

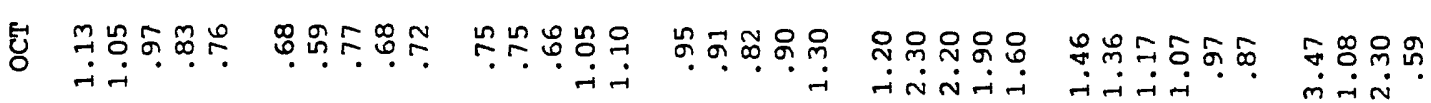
नन

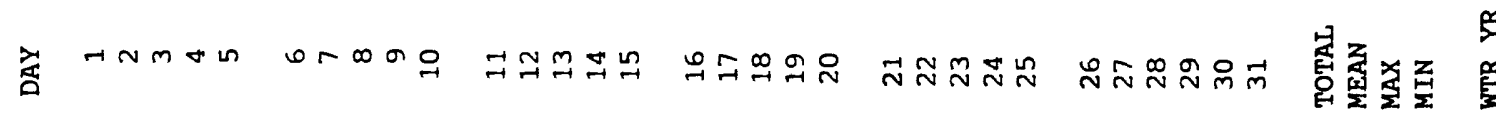




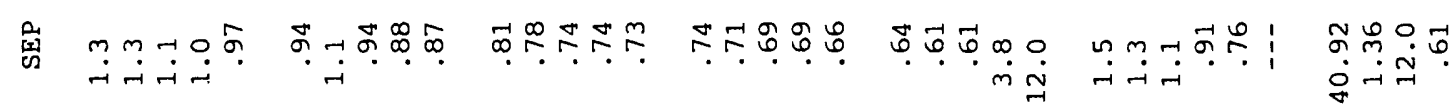

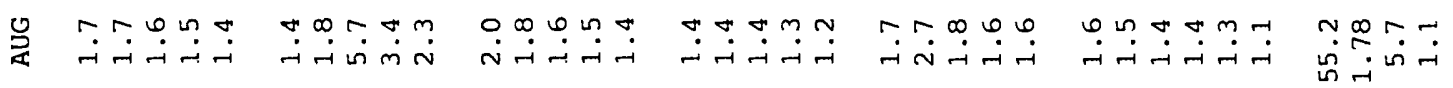

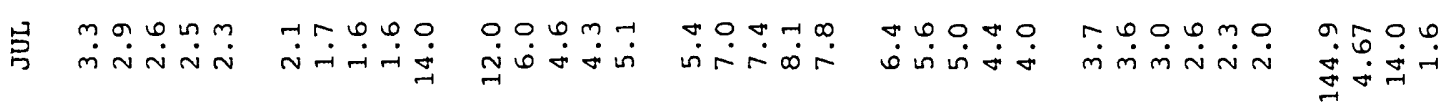

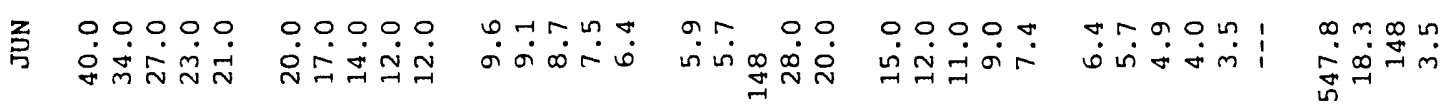

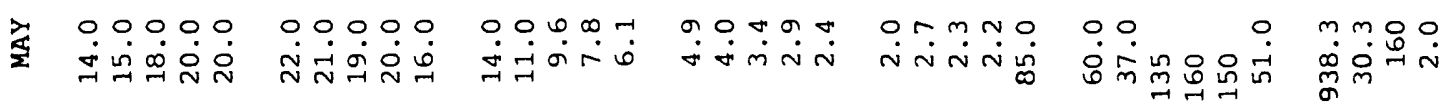

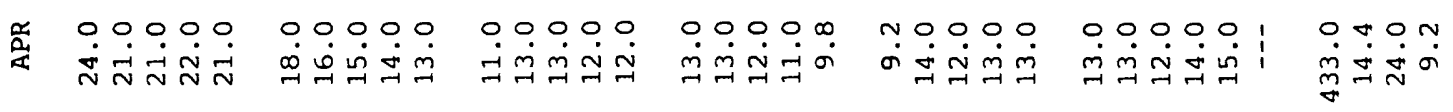

采

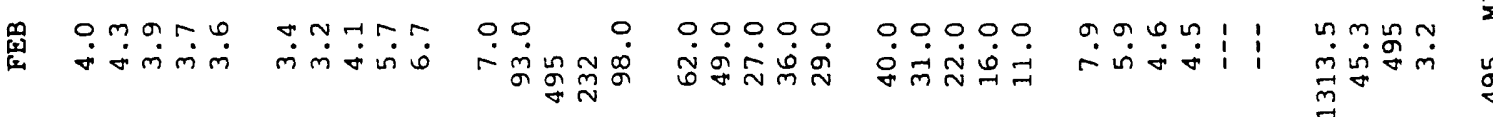

质

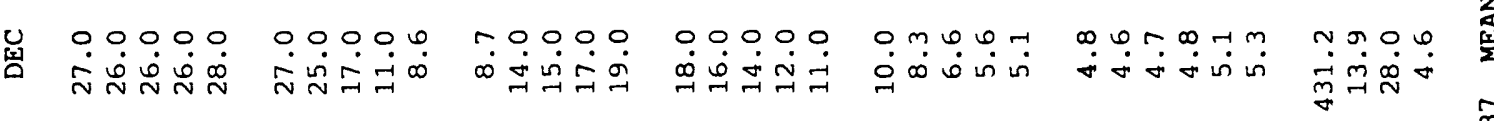

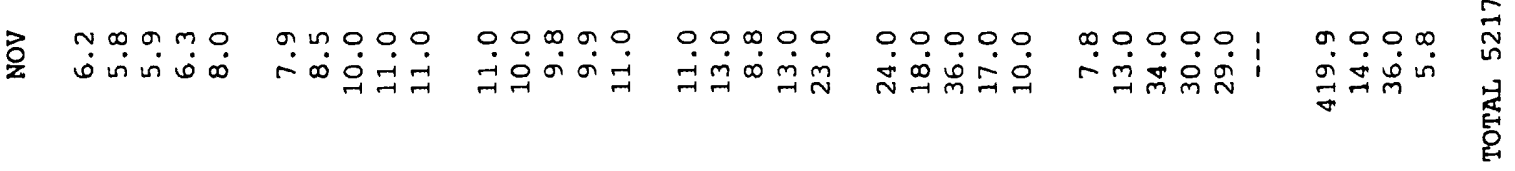

E

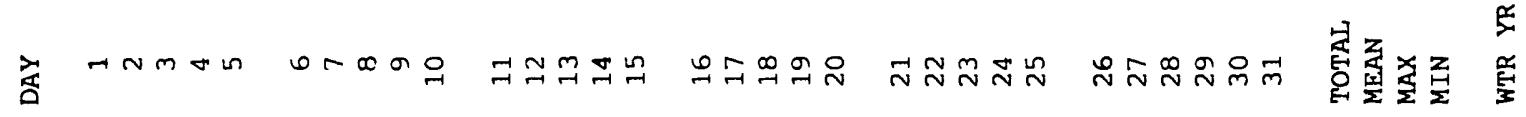




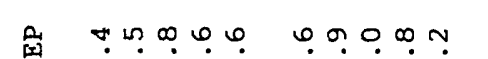

它

逐

$\sin$

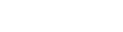

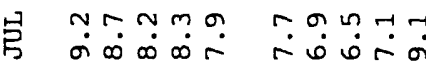

ar

$\dot{\infty}$

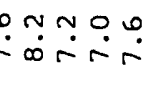

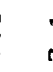

요뭉

$m \sim \operatorname{mon}_{0}$

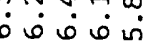

ำ

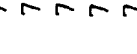

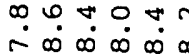

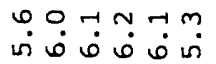

in

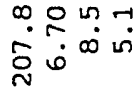

节

o.m.r.

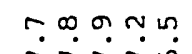

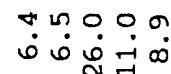

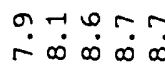

กัดัดำ

$\stackrel{\infty}{\infty} \sigma 0 \dot{\infty}$

خัخ

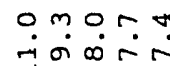

ำ

ตำ

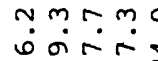

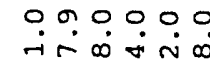

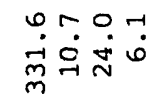

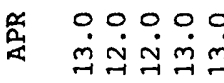

우웅

ก. ก 9.9 .

0.000

नंनें

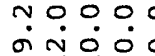

아우이

தंणंळ்

a Non

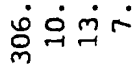

采

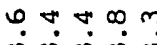

$\because \Upsilon \mathscr{\varphi} \bullet$

พ

0.900 $\dot{\sim} \dot{\infty} \dot{\sim} \ddot{\sim} \dot{\sim}$

0.00

毛完品

0.0000

ஸ่

roor $\dot{\sigma} \sim \dot{\sigma} \dot{\circ} \dot{\infty}$

$m$ m

กษระ

․․․․ 0.0000

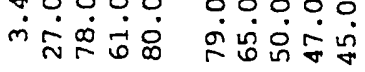

0.000 $\dot{m} \dot{m} \dot{\sim} \dot{\sim} \dot{\sigma} \dot{\sim}$

우우

ก ง 官

否

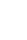

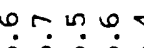

Hnato

tor

$\forall \infty \sim \infty$ ف ف ف ف

صำ

مُ

놈 0.0000

$0.0 \div \div$

10

के




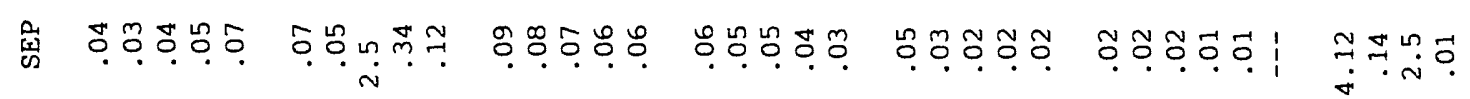

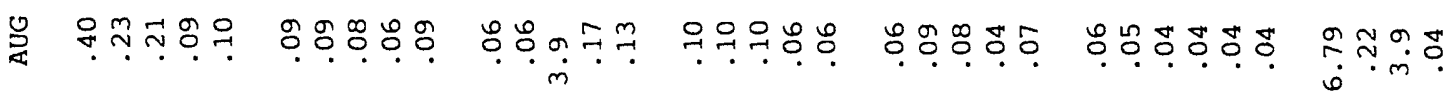

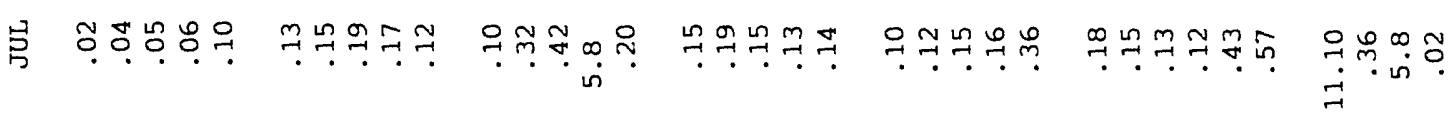

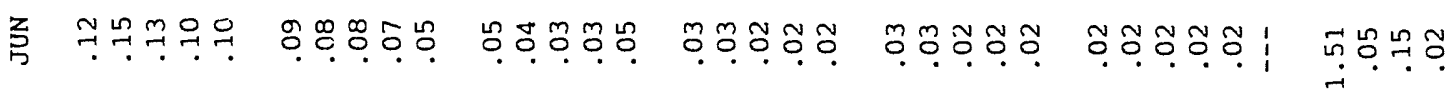

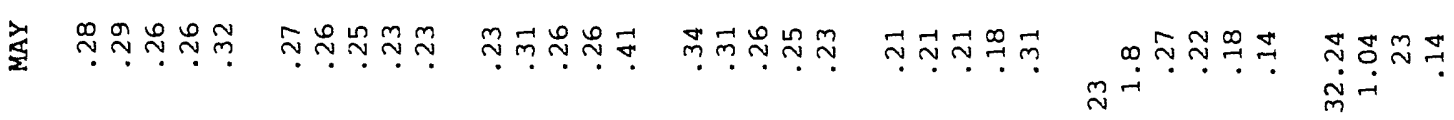

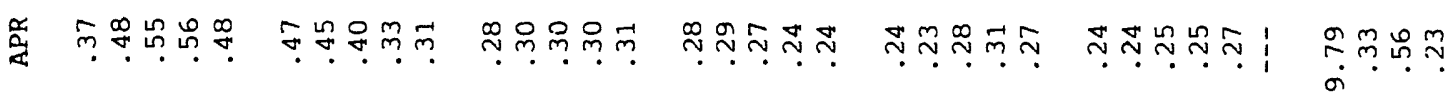

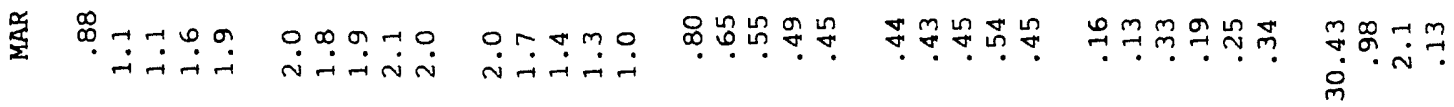

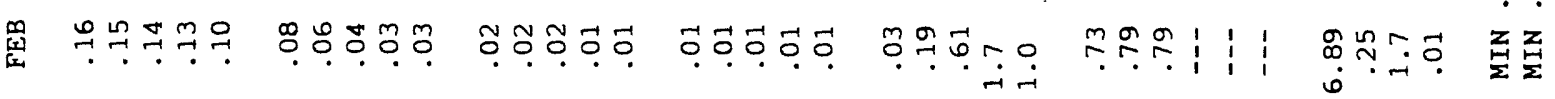
$\exists$

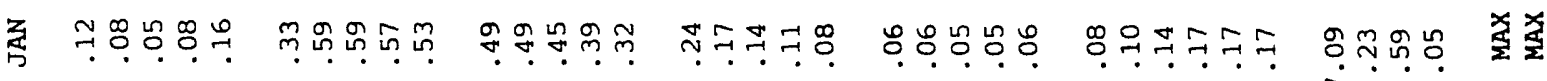
m.

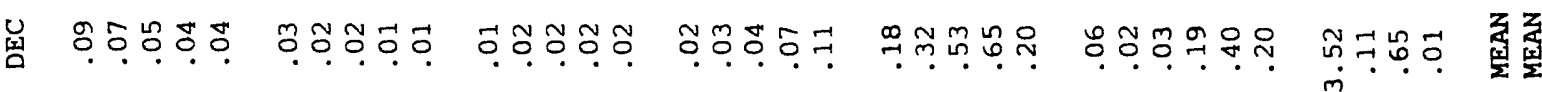

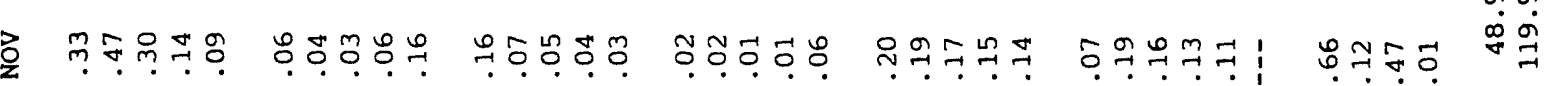

๙ิ

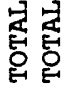

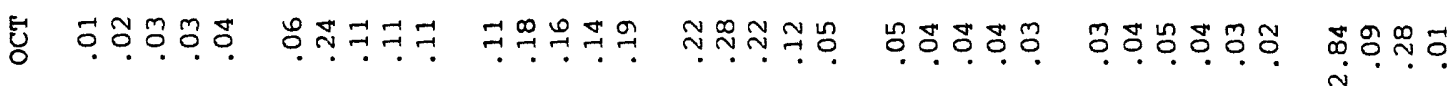

落

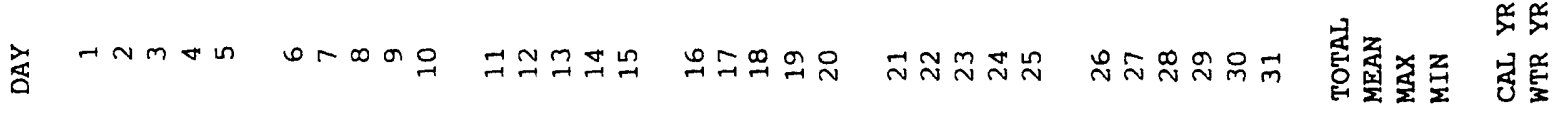




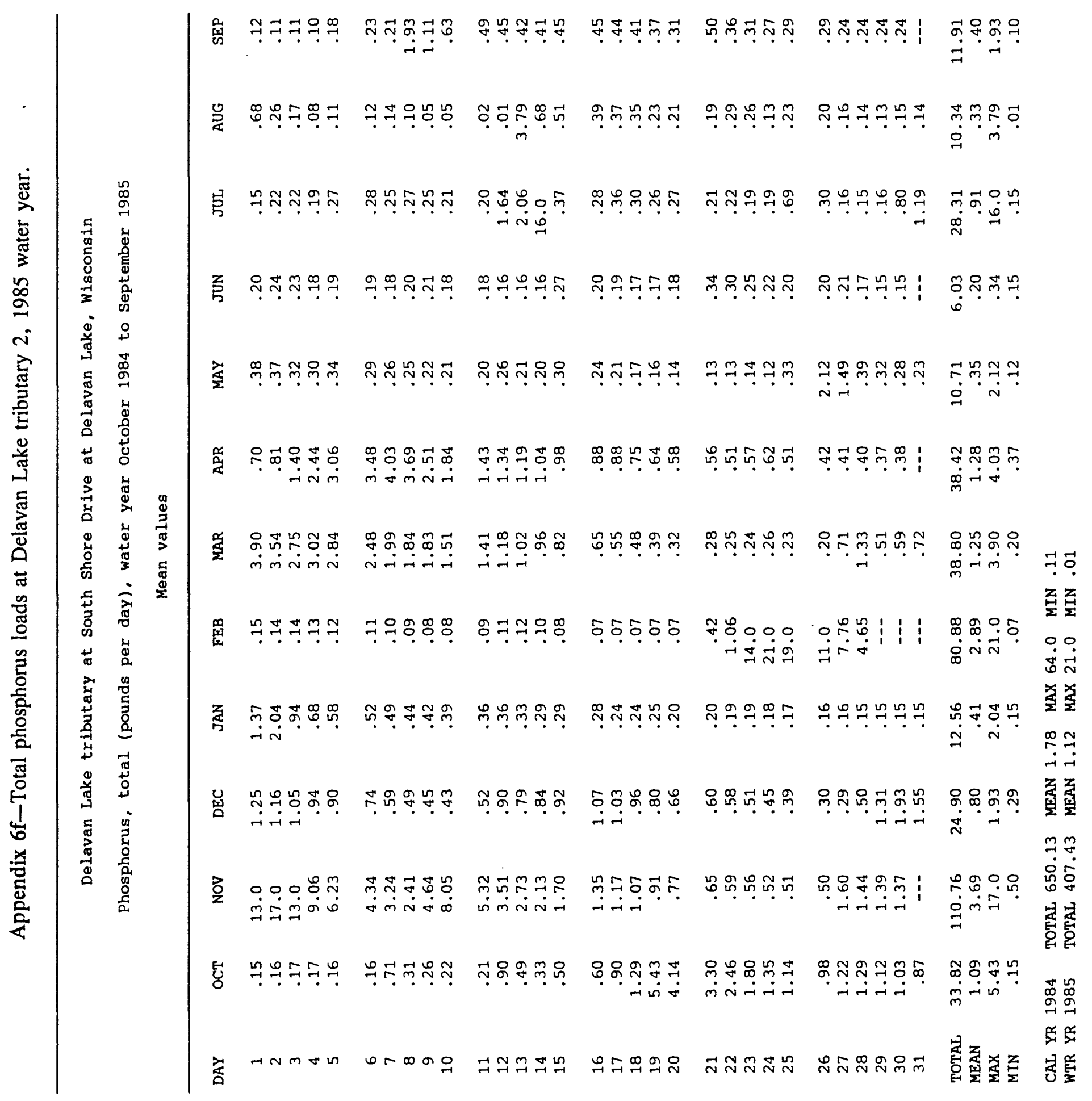




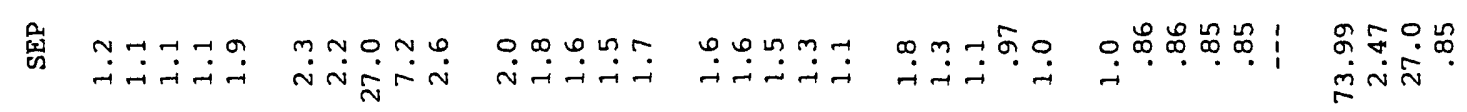

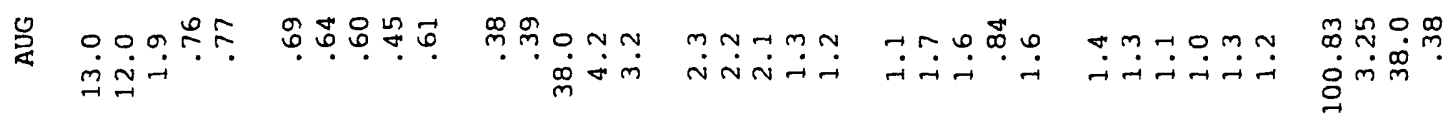

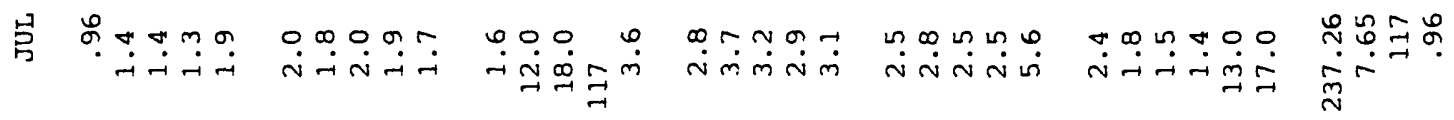

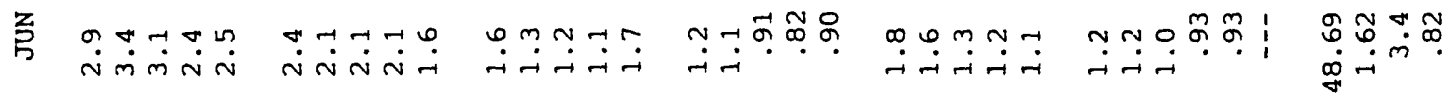

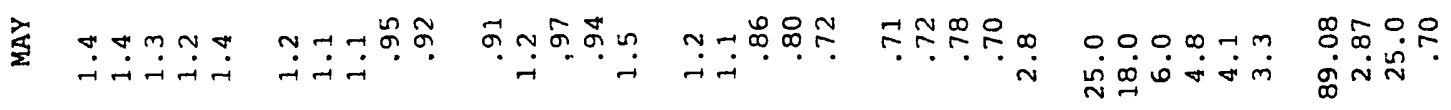

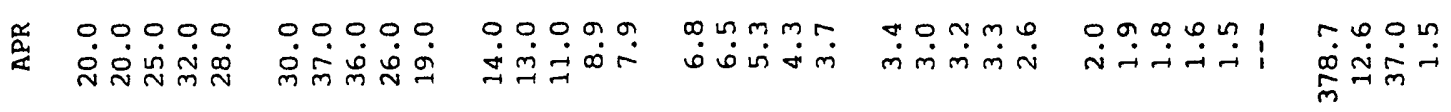

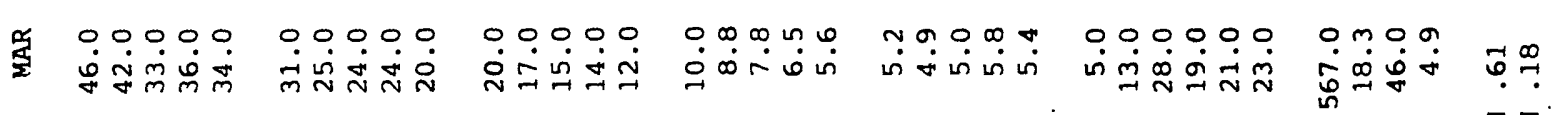

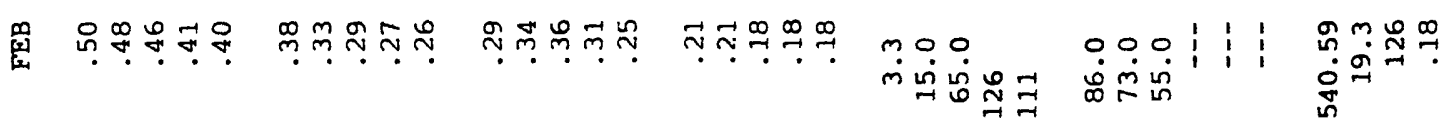

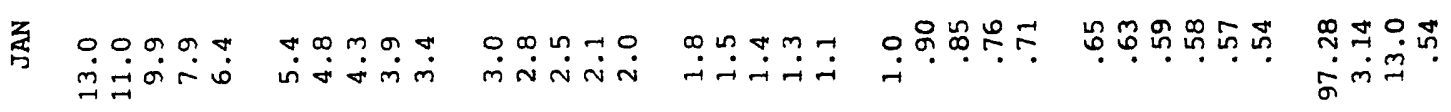

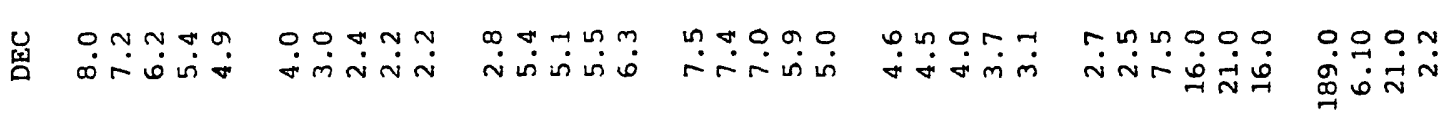
z

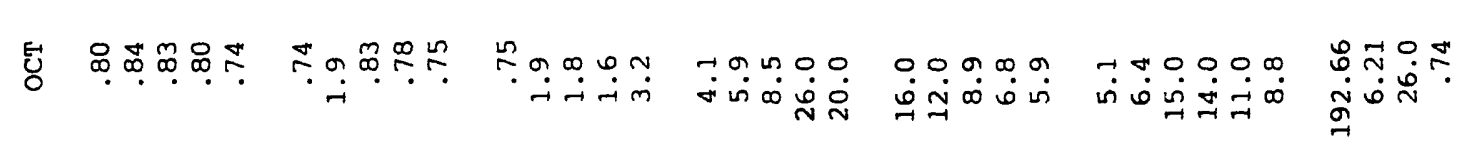
专表 紫 줄

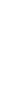
을

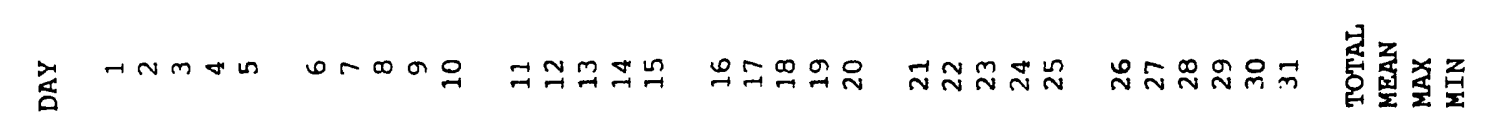
$\underset{\substack{\infty \\ \infty}}{\stackrel{\circ}{\infty}}$ 凅蛋 고 กำ in 衰朂 唸恕 Ex 存孚 


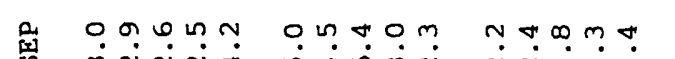

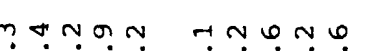

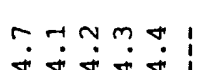

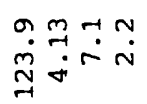

荤

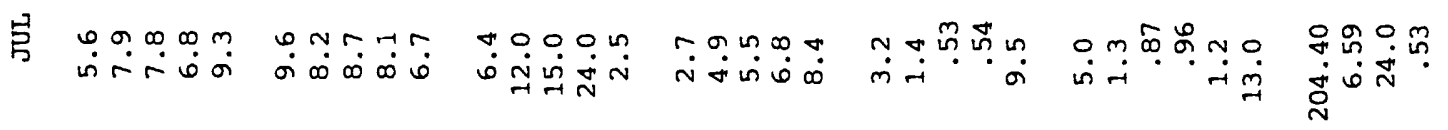

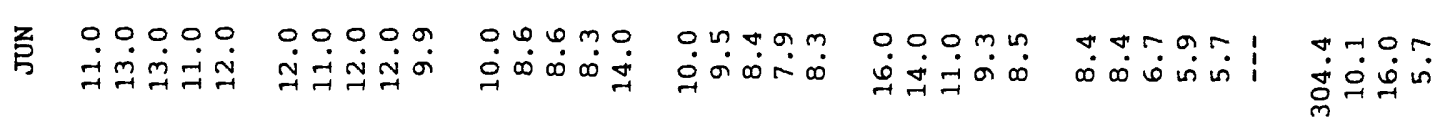

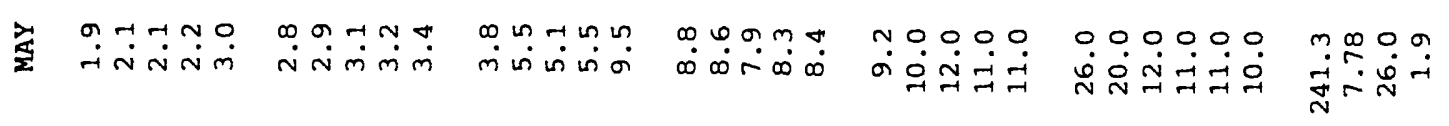

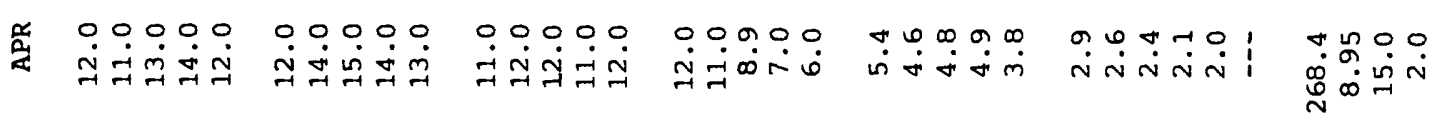

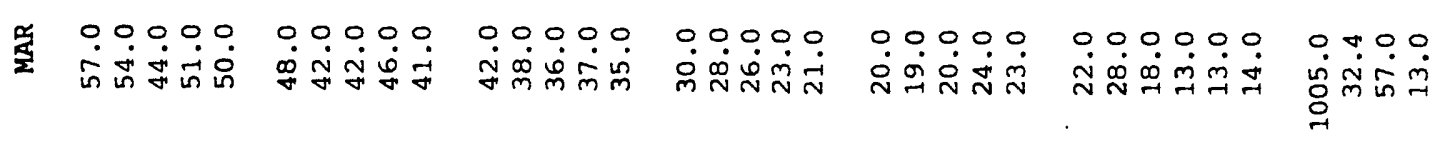

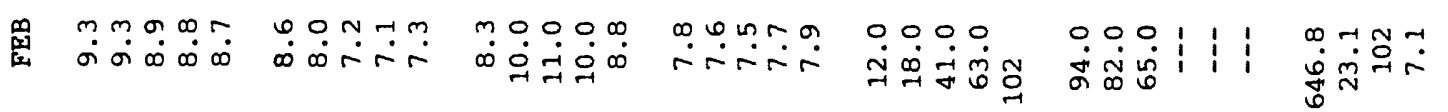

蛋

空空

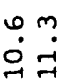

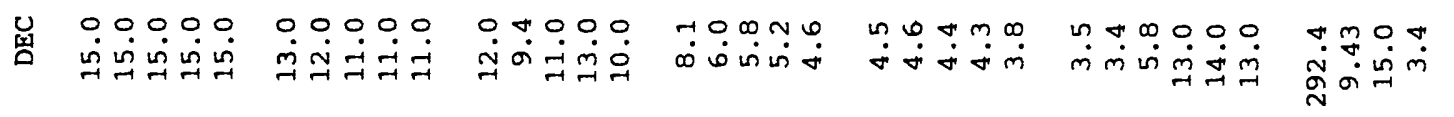

受密

เึ็์

它

z

㪙朂

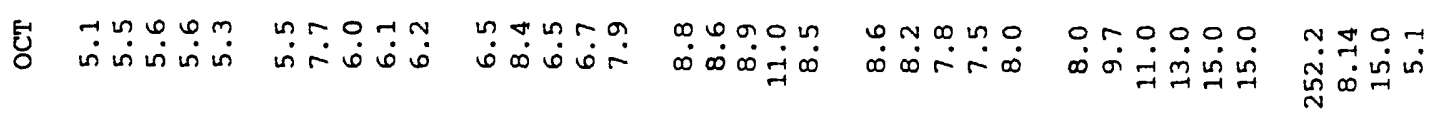

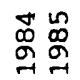

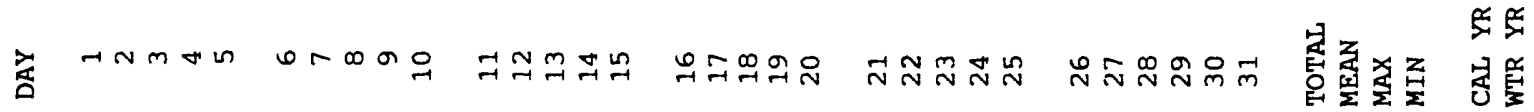




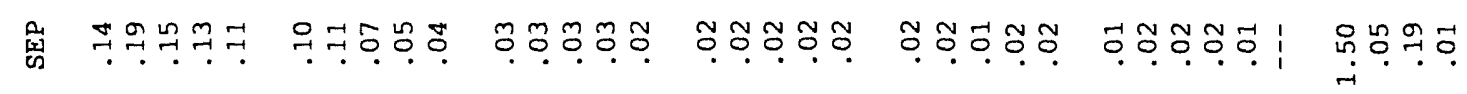

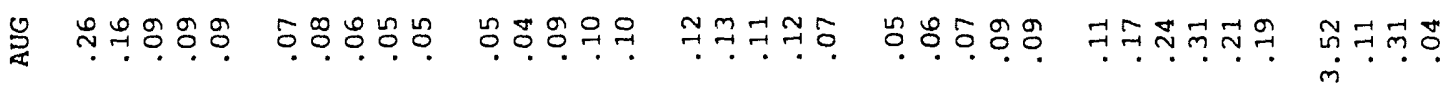

है

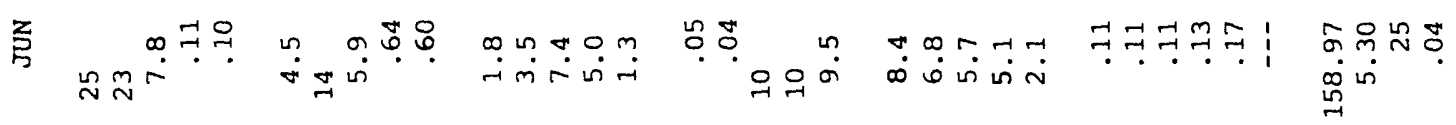

承

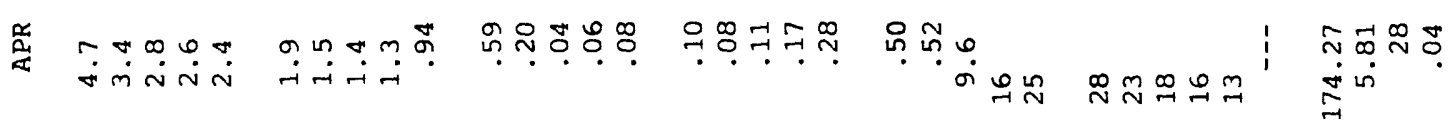

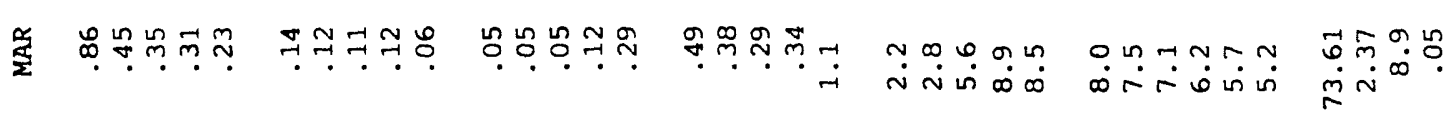

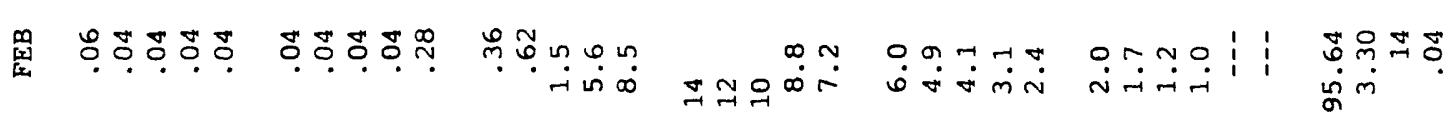

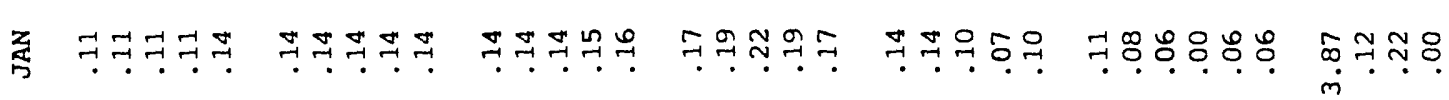

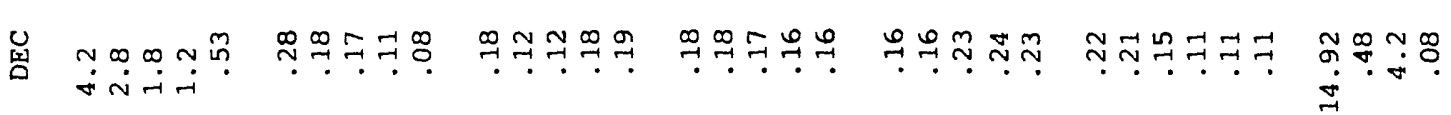

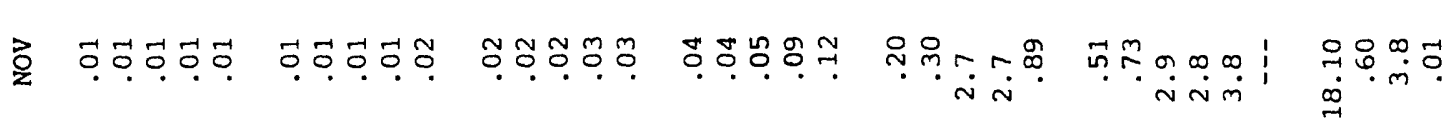

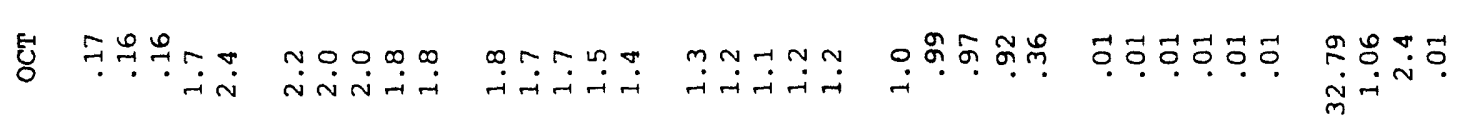
竞

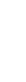




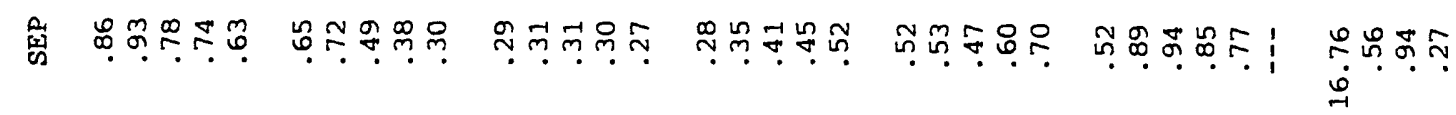

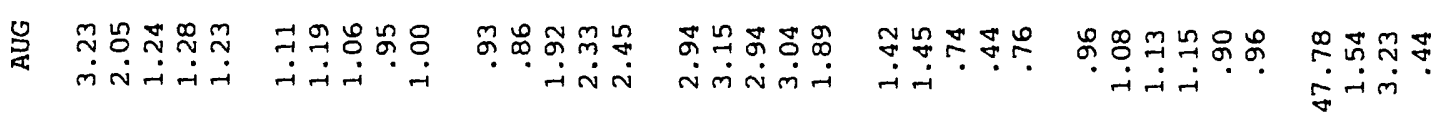

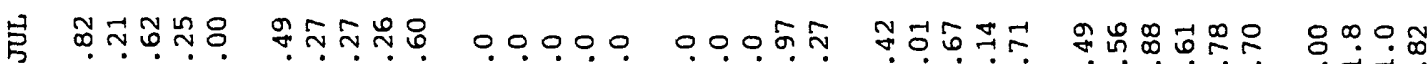

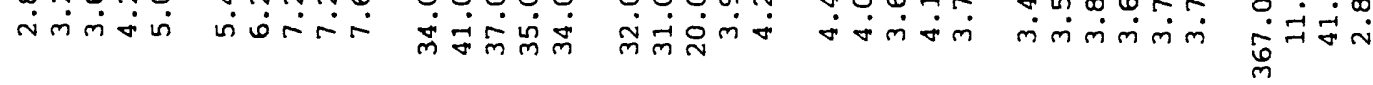

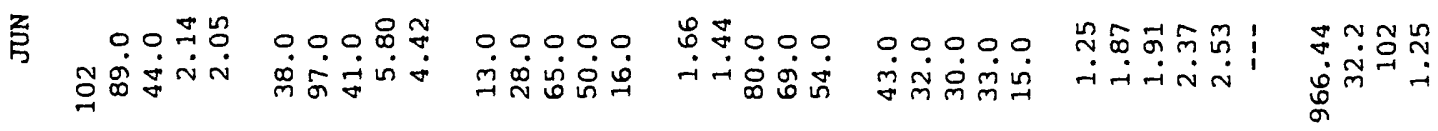

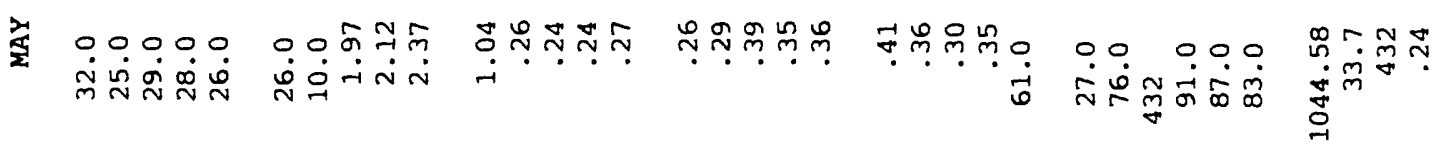

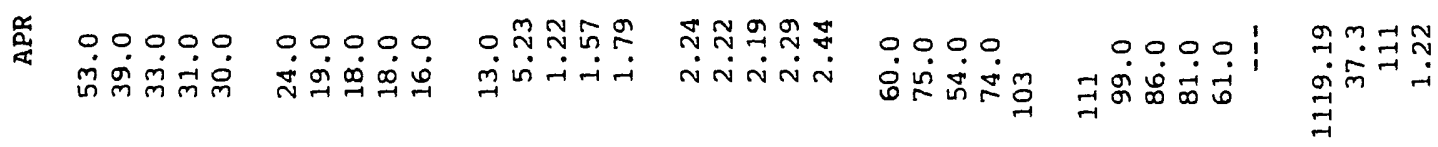

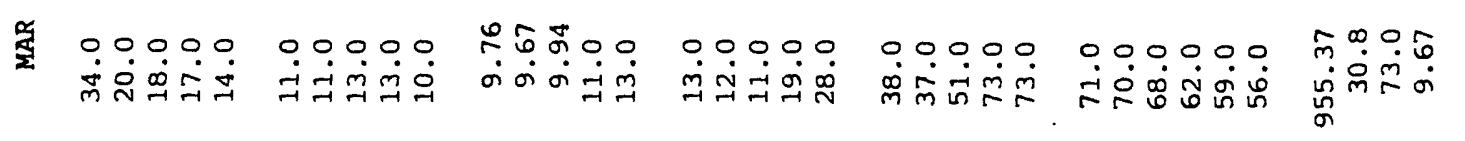

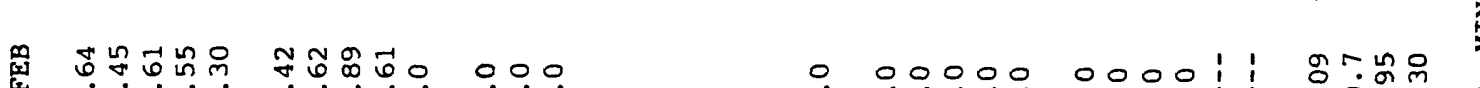

罢

䒺

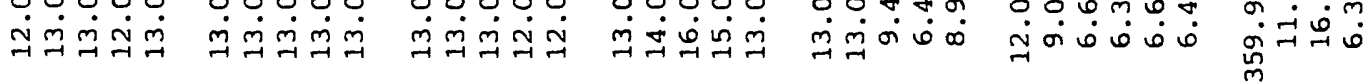

U 000000000000000000000000000000000 苔 z

E

苔 $\rightarrow$ N 


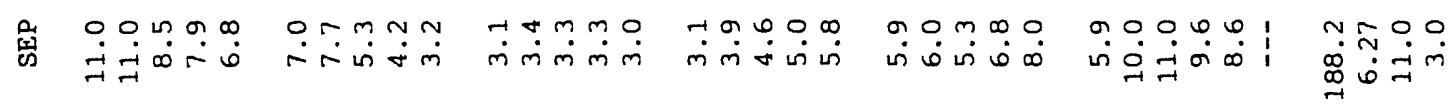

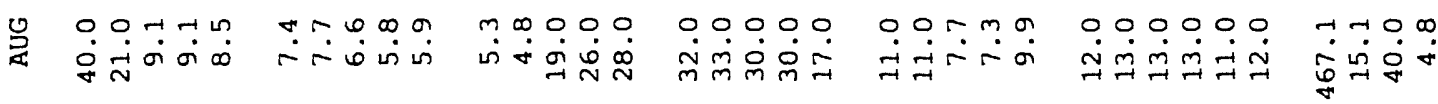

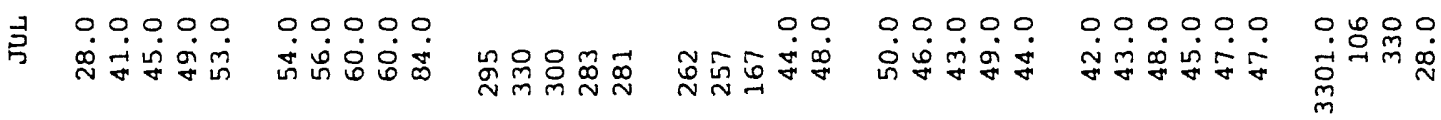

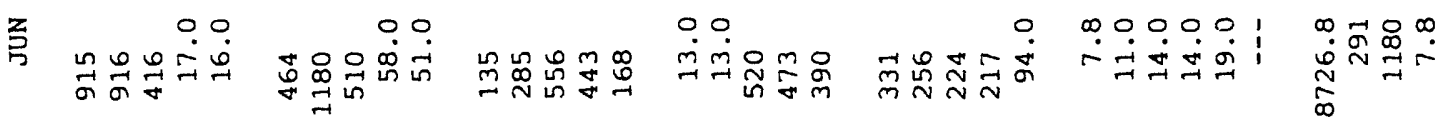

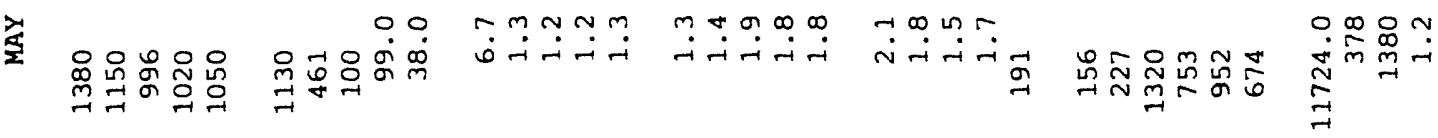

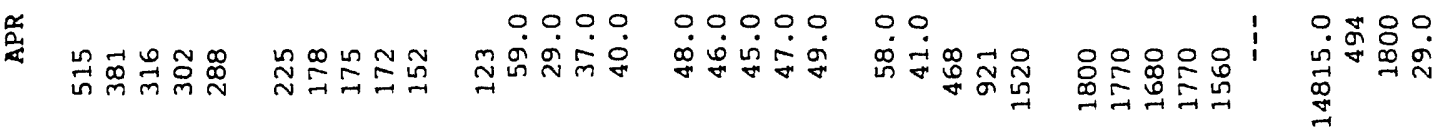

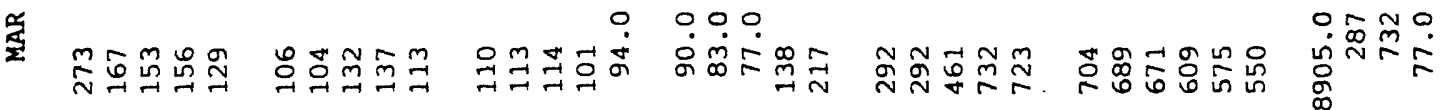

0000000000

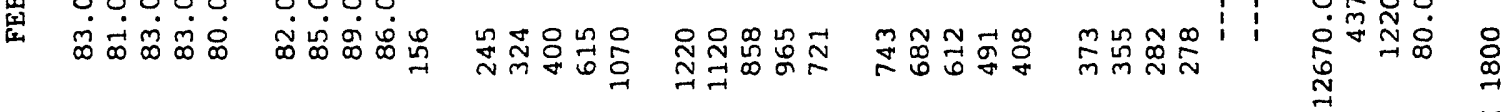

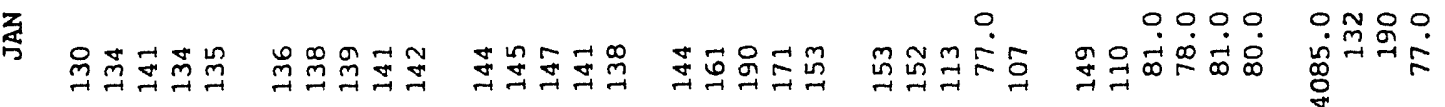

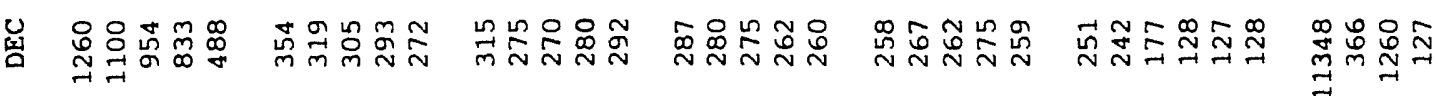

Z

矛

씀 


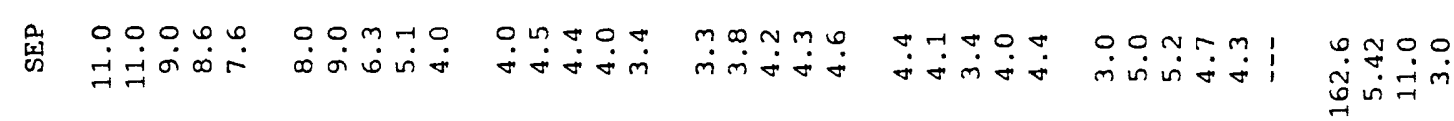

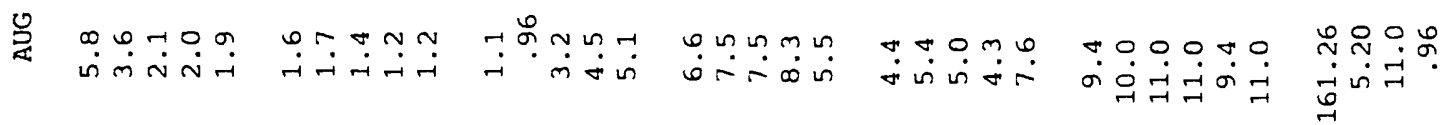

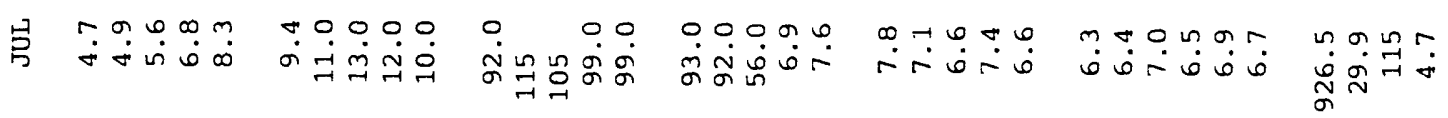

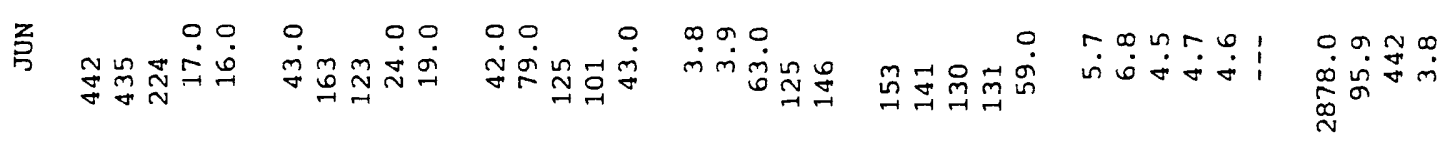
旁

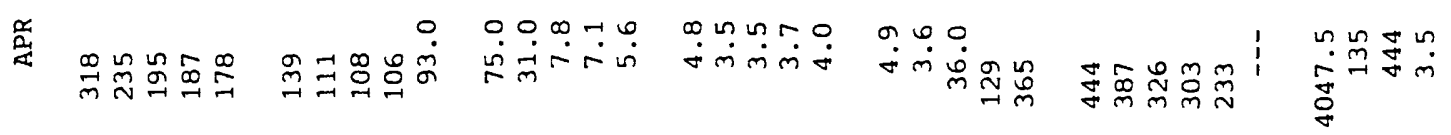
20.000 $00000 \quad 0.000 .000$

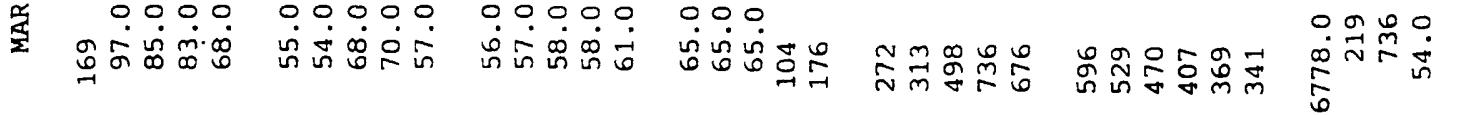
罢

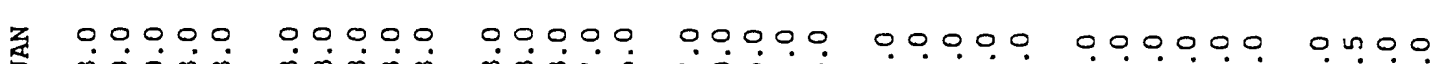

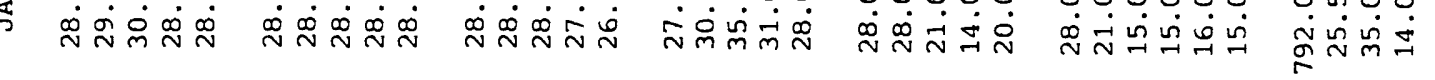
曾 z E ○

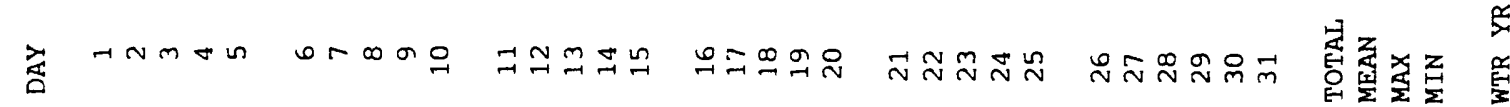




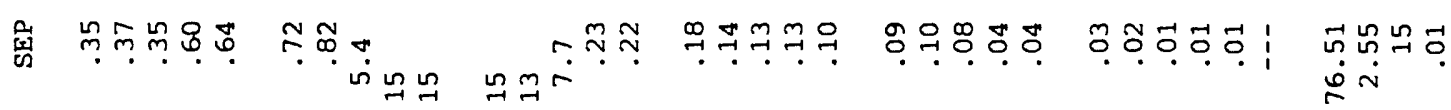

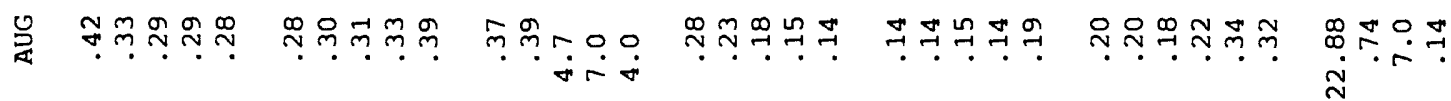

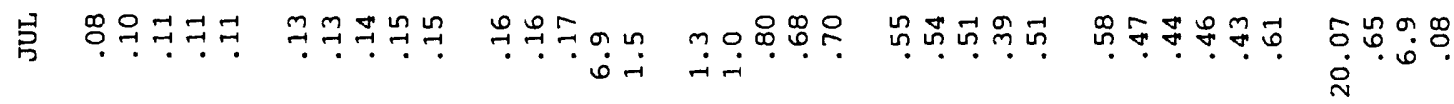

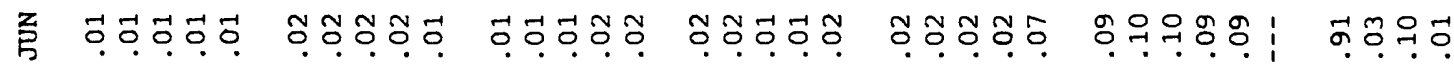

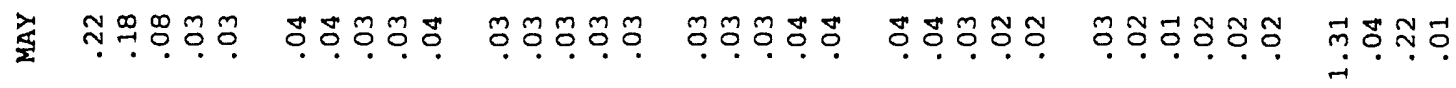

善

递

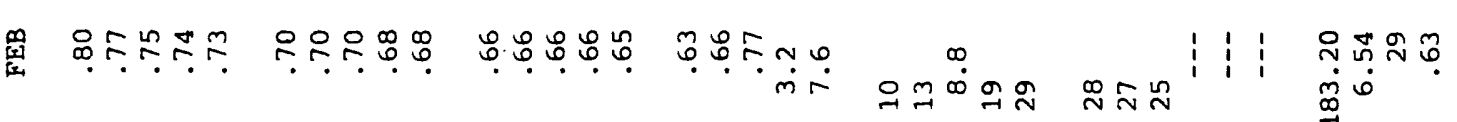

ํํ.

育

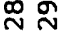

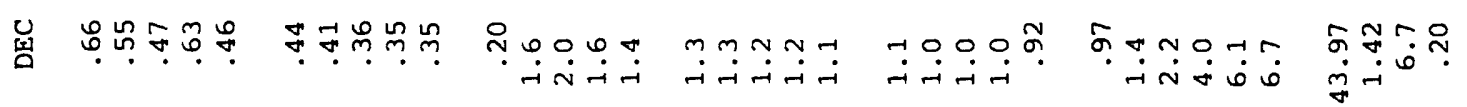

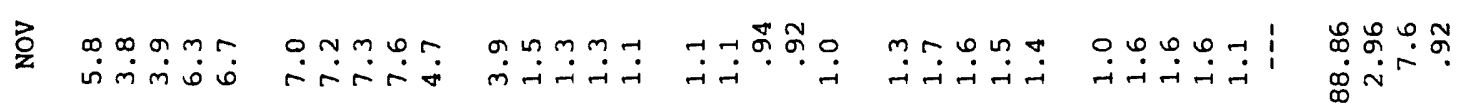
ำ จิ

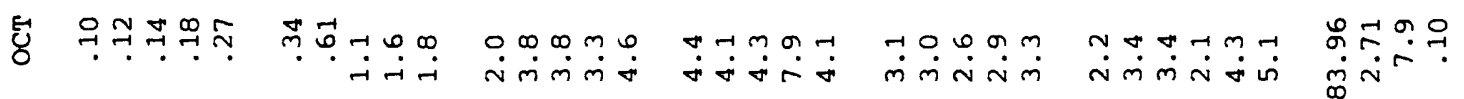

萬怘

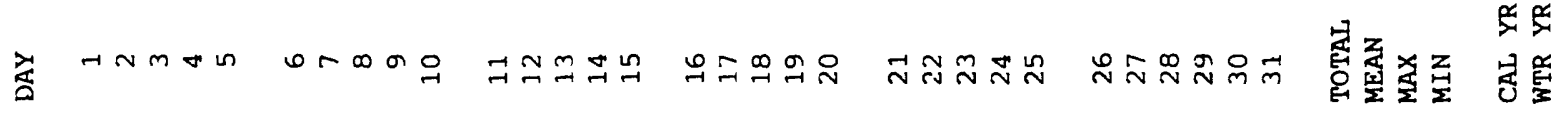




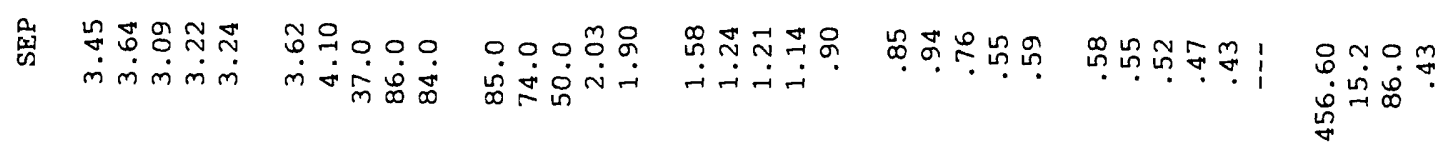

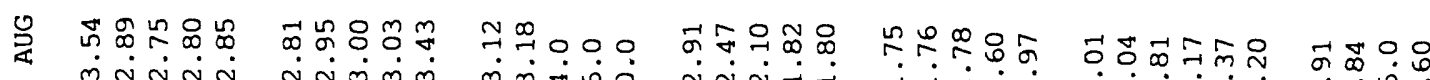

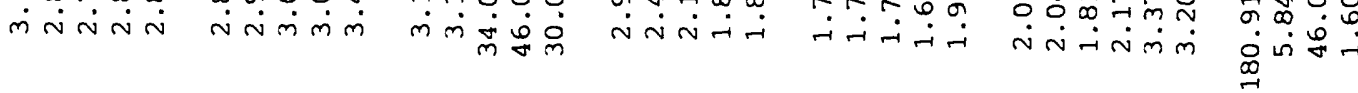

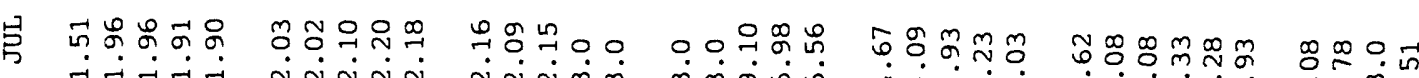

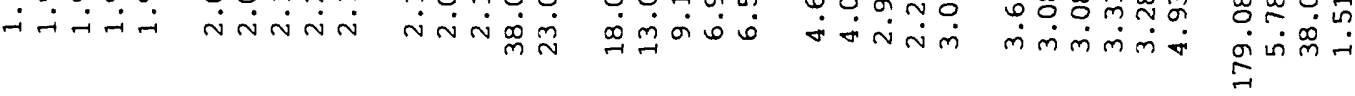

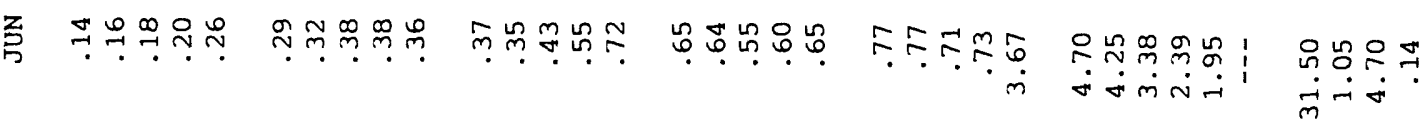

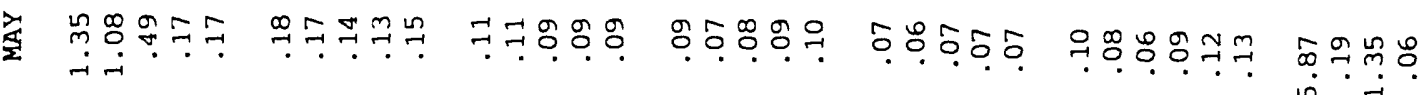

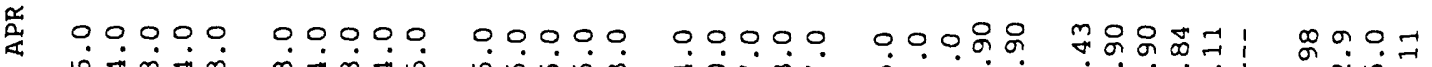

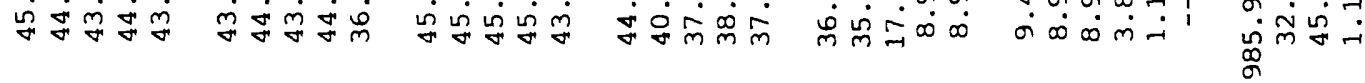

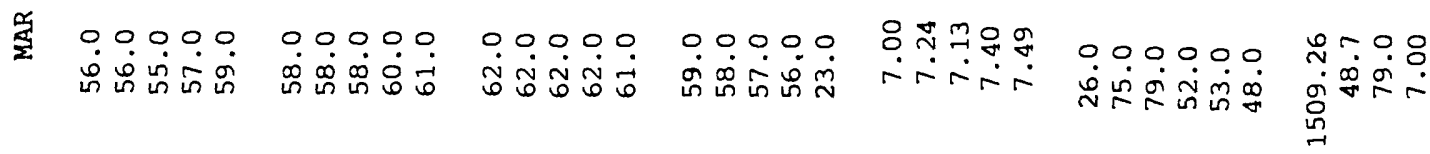

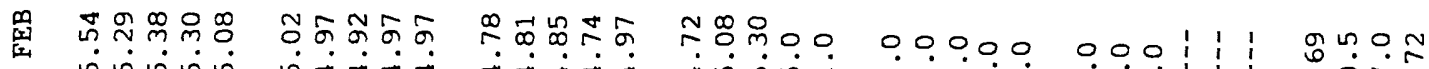
ம்

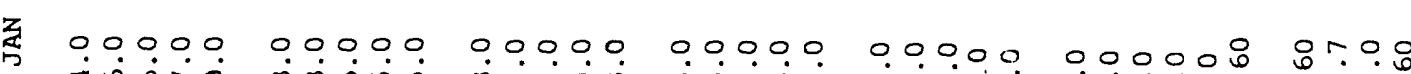

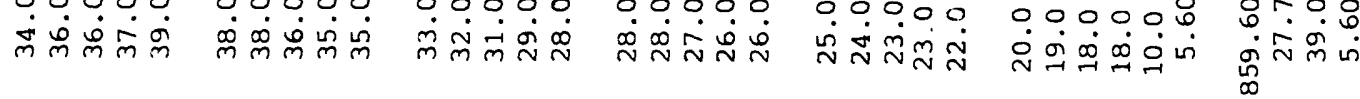

曾

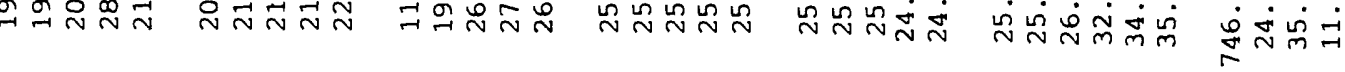

z

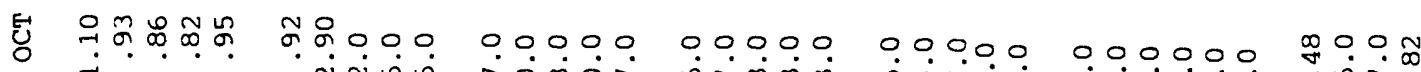

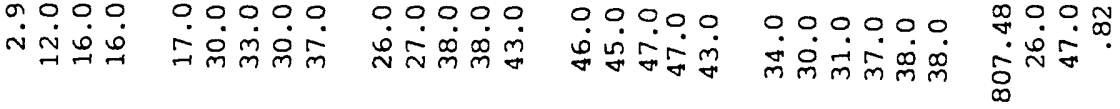

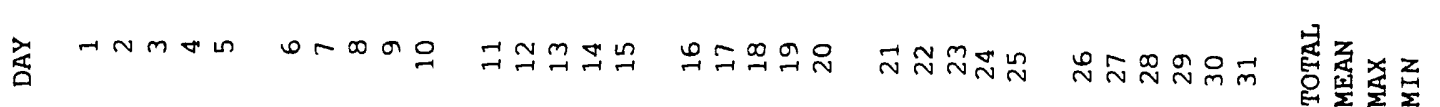

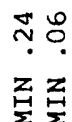

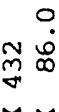

줄

in

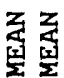

용

$\stackrel{\infty}{\stackrel{m}{m}}$

芯怘

$x$

붕 
D. 0.0.0. 0.0

00

$\operatorname{mog} \infty$

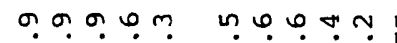

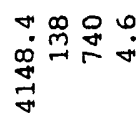

$\stackrel{\mathscr{\infty}}{\sigma}$

- 0.0.0. 0.0.0. 0.

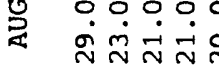

ต่ $\dot{\sim} \dot{\sim} \stackrel{\sim}{n}$

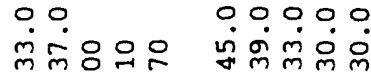

00000

000000

우우우.

岇完

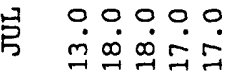

0.0 .0 .000

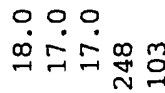

0.0 .0

0.000

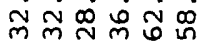

.

z

$m .0 .7 \cdot r$

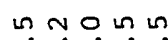

舟市的家

审岀完

0.0 .0 .0 .0

0.0 .90 过

Or. o om

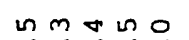

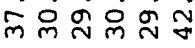

$\rightarrow$

mָ

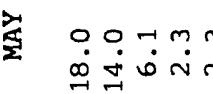

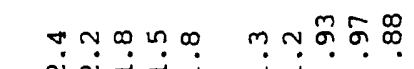

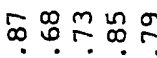

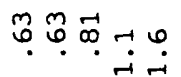

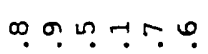

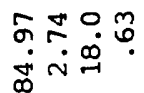

总 m $\stackrel{m}{\sim} \underset{\sim}{\infty} \stackrel{\infty}{N}$

กูก ชูกนีก

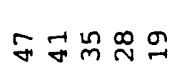

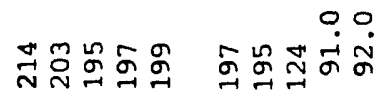

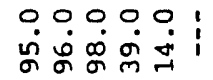

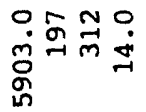

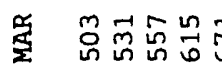

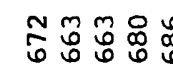

\section{ธุญ}

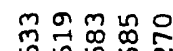

ำㅋำ 옥

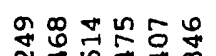

ำดั

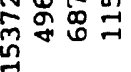

a

数

نं $\dot{\forall} \dot{j} \dot{m}$

نें

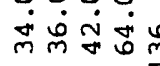

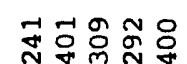

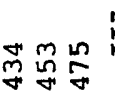

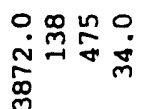

育

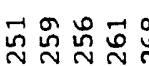

:

(2)

aOmLn

ㅇํ요

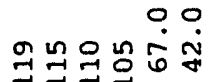

$\circ \stackrel{\infty}{0} 0$.

กูกิ

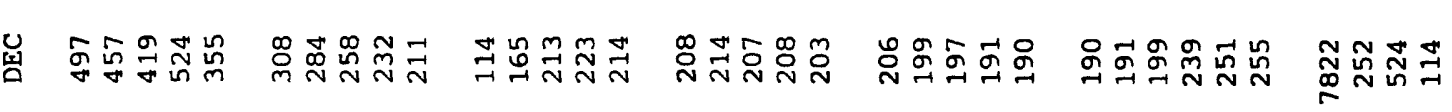

กัก

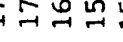

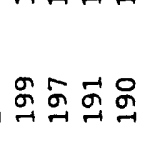

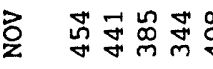

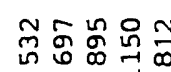

육원옹유융

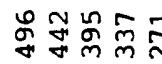

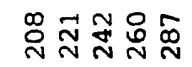

式芯亭热出!

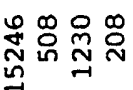

E

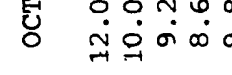

ต் $\stackrel{\sim}{\rightarrow}$

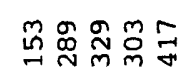

品点芯贴

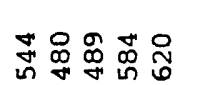

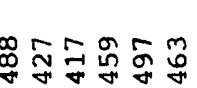

?.

융 융

ํํำ

突 ナNmナ゙

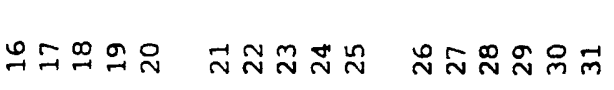

ㅇํㅇ

品芒 


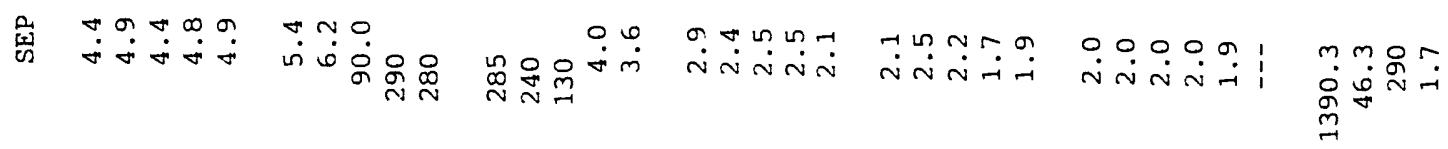

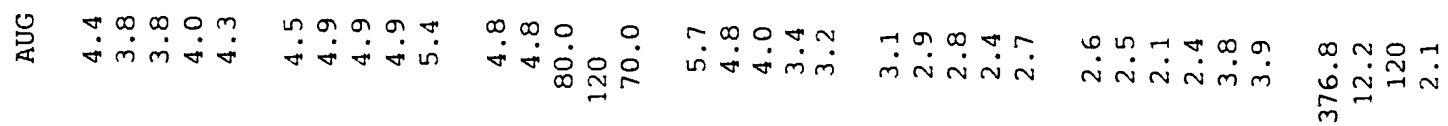

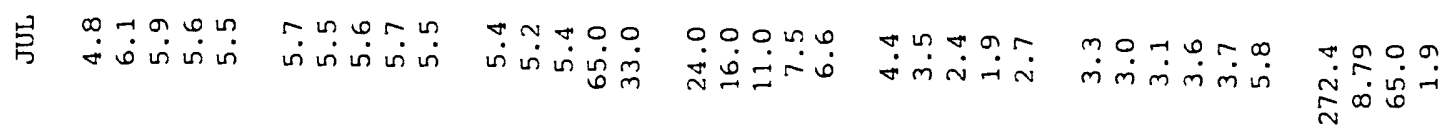

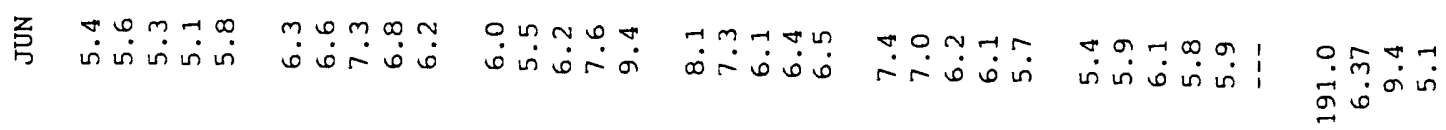

商

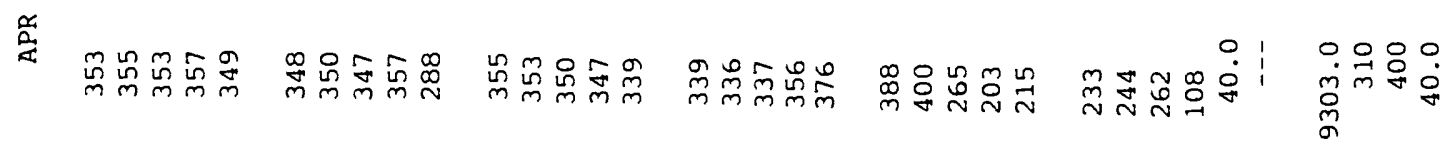

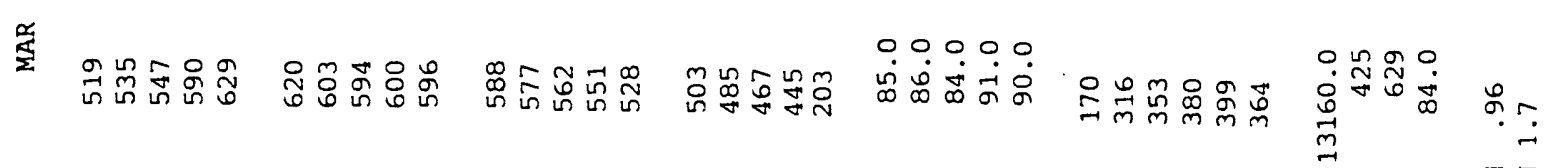

置

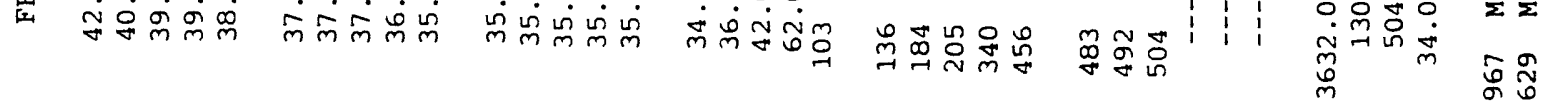

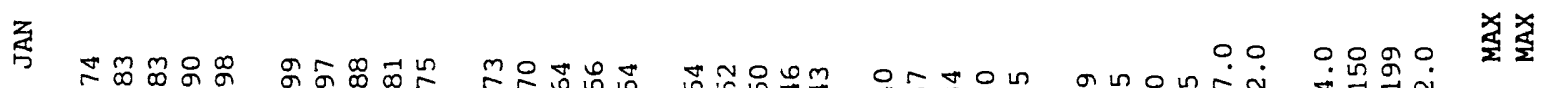

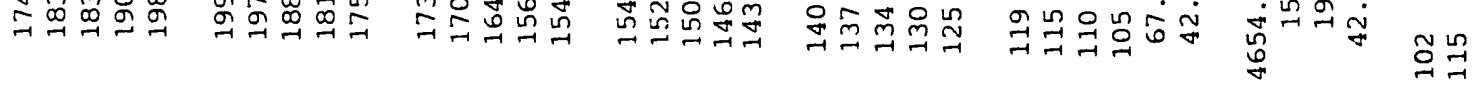

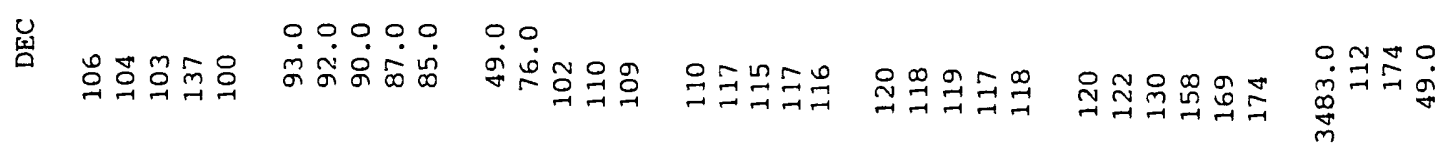

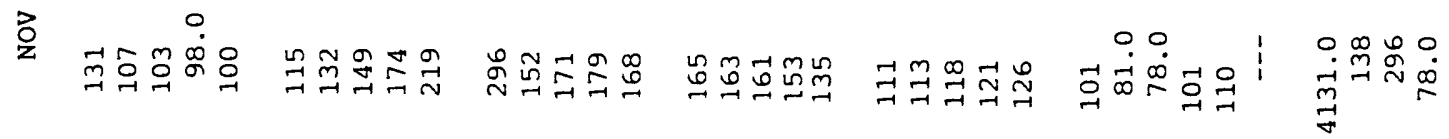

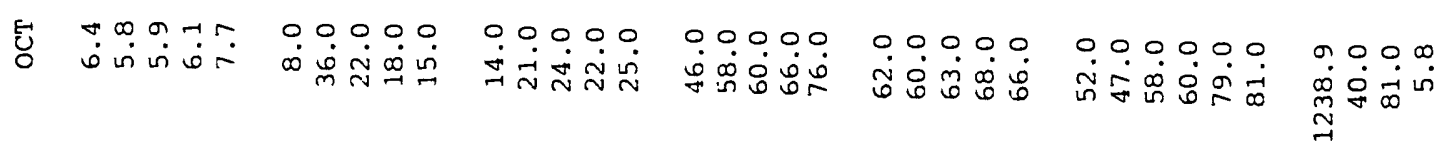

$z_{3}$

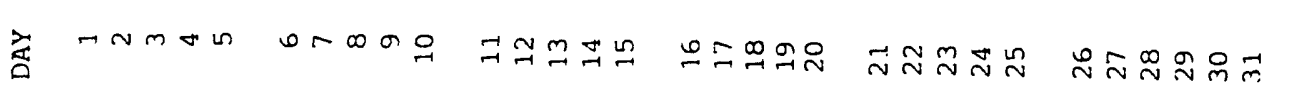

